\title{
Belgium: Detailed Assessment of Compliance with the Basel Core Principles for Effective Banking Supervision
}

This paper was prepared based on the information available at the time it was completed on May 16, 2013. The views expressed in this document are those of the staff team and do not necessarily reflect the views of the government of Belgium or the Executive Board of the IMF.

The policy of publication of staff reports and other documents by the IMF allows for the deletion of market-sensitive information.

\footnotetext{
Copies of this report are available to the public from

International Monetary Fund • Publication Services

700 19th Street, N.W. • Washington, D.C. 20431

Telephone: (202) 623-7430 • Telefax: (202) 623-7201

E-mail: publications@imf.org • Internet: http://www.imf.org
}

\section{International Monetary Fund Washington, D.C.}




\title{
INTERNATIONAL MONETARY FUND
}

\section{BELGIUM}

\author{
FINANCIAL SECTOR ASSESSMENT PROGRAM
}

May 16, 2013

\section{DETAILED ASSESSMENT OF OBSERVANCE}

BASEL CORE PRINCIPLES FOR EFFECTIVE BANKING SUPERVISION 


\section{Prepared By}

Monetary and Capital Markets Department

\section{CONTENTS}

SUMMARY, KEY FINDINGS, AND RECOMMENDATIONS 4

A. Introduction ___ 5

B. Information and Methodology Used for Assessment ___ 5

INSTITUTIONAL AND MACROECONOMIC SETTING AND MARKET STRUCTURE OVERVIEW

A. Preconditions for Effective Banking Supervision ___ 9

B. Main Findings __ 12

C. Authorities' Response to the Assessment ___ 27

DETAILED ASSESSMENT__ 32

\section{TABLES}

1. Summary Compliance with the Basel Core Principles_Detailed Assessments ___ 18

2. Recommended Action Plan to Improve Compliance with the Basel Core Principles ___ 25

3. Detailed Assessment of Compliance with the Basel Core Principles___ 32 


\section{Glossary}

$\begin{array}{ll}\text { AC } & \text { Additional Criteria } \\ \text { AML/CTF } & \text { Anti-Money Laundering/Combating Terrorist Financing } \\ \text { BCPs } & \text { Basel Core Principles } \\ \text { BRGAAP } & \text { Belgian Generally Accepted Accounting Principles } \\ \text { CBFA } & \text { Commission Bancaire, Financiers et Assurances } \\ \text { CPs } & \text { Core Principles } \\ \text { EC } & \text { Essential Criteria } \\ \text { ECB } & \text { European Central Bank } \\ \text { EEA } & \text { European Economic Area } \\ \text { EU } & \text { European Union } \\ \text { FATF } & \text { Financial Action Task Force } \\ \text { FSAP } & \text { Financial Sector Assessment Program } \\ \text { FSMA } & \text { Financial Services and Markets Authority } \\ \text { GIIPS } & \text { Greece, Italy, Ireland, Portugal, and Spain } \\ \text { IAS } & \text { International Accounting Standards } \\ \text { ICAAP } & \text { Internal Capital Adequacy Assessment Process } \\ \text { IFRIC } & \text { International Financial Reporting Interpretations Committee } \\ \text { IFRS } & \text { International Financial Reporting Standards } \\ \text { IRB } & \text { Internal Rating-based Approach } \\ \text { KYC } & \text { Know Your Customer } \\ \text { LCR } & \text { Liquidity Coverage Ratio } \\ \text { LGD } & \text { Loss Given Default } \\ \text { MiFID } & \text { Markets in Financial Instruments Directive } \\ \text { MoU } & \text { Memorandum of Understanding } \\ \text { NBB } & \text { National Bank of Belgium } \\ \text { NSFR } & \text { Net Stable Funding Ratio } \\ \text { PF } & \text { Protection Fund for Deposits and Financial Instruments } \\ \text { SPF } & \text { Special Protection Fund for Deposits, Life Insurance and Capital of } \\ \text { SREP } & \text { Cooperative Companies } \\ \text { VaR-model } & \text { Value at Risk Model } \\ & \end{array}$




\section{SUMMARY, KEY FINDINGS, AND RECOMMENDATIONS}

\section{Belgium has a high level of compliance with the Basel Core Principles for Effective} Banking Supervision (BCPs). This high level of compliance has been achieved in a challenging environment. The financial crisis and subsequent state intervention has transformed the banking system and while acute crisis conditions have abated there is continued elevated stress within the system and vulnerabilities persist. Added to this is the continued pressure on industry to meet forthcoming higher regulatory standards, most notably in capital and liquidity. These conditions put a premium on the quality of risk management practices within the banks themselves and equally on the supervisory oversight conducted by the authorities. In addition to substantial regulatory changes, the supervisory authorities have also had to adjust to the challenges of transition wrought by re-design of the regulatory architecture and the move of prudential supervision to the central bank.

2. The National Bank of Belgium (NBB) deploys high-quality supervisory practiceswhich it is building upon through well conceived initiatives and reforms-but there are weaknesses in its supervisory process. The NBB has already instituted some enhancements to its risk oversight, such as an annual risk review, and is executing a focused but multi-faceted plan of improvements. These projects will streamline and integrate processes, create greater flexibility in data handling and strengthen and deepen analysis at firm specific and horizontal levels. It is important for the NBB to fully harness these projects in refining its risk based supervisory processes to ensure that it has identified the minimum adequate level of supervisory attention for each institution according to the institution's risk profile. Should crisis conditions re-emerge there will be consequential effects on the entire supervisory process as limited resources will need to be reallocated. The NBB needs to be able to rely on its supervisory processes to guide its decision making in order to manage such reallocation in a fully risk-focused manner. The embedding of this more systematic process would allow the NBB to ensure that the dilution of supervisory activity is dispersed proportionately.

3. An area of weakness in the large exposure regime allows for concessions to smaller banks to exceed the 25 percent limit. Where the amount of $€ 150$ million is higher than 25 percent of the own funds, the value of the exposure, after credit risk mitigation, is allowed to exceed the 25 percent limit up to 100 percent of own funds. The concession is not peculiar to Belgium and is derived from Directive 2009/111/EC that has modified Directive 2006/48/EC and a national discretion is however foreseen in order to set a stricter limit (four banks within the EC have done so). While the concession is permitted under the Directive, the concession significantly weakens the regime and exposes smaller banks to concentration risk. In practice, smaller banks don't have access to deep capital markets to quickly raise capital in the event an exposure to an obligor defaults or becomes impaired. 


\section{A. Introduction}

4. This assessment of the current state of the implementation of the BCPs in Belgium has been completed as part of a Financial Sector Assessment Program (FSAP) undertaken by the International Monetary Fund (IMF) during 2012. It reflects the regulatory and supervisory framework in place as of the date of the completion of the assessment. Importantly, it is not intended to assess the merits of the important policy and implementation issue regarding several aspects of the international regulatory framework that are yet to be decided in international fora, the European Union (EU), and in Belgium, ranging from the finalization of the Basel III liquidity regime to the potential creation of a Single Supervisory Mechanism. An assessment of the effectiveness of banking supervision requires a review of the legal framework, both generally and as specifically related to the financial sector, and detailed examination of the policies and practices of the institutions responsible for banking regulation and supervision. In line with the BCP methodology, the assessment focused on the major banks and banking groups, and their regulation and supervision, given their importance to the system.

\section{B. Information and Methodology Used for Assessment}

5. The Belgian authorities agreed to be assessed according to the Core Principles (CP) Methodology issued by the Basel Committee on Banking Supervision (Basel Committee) in October 2006. The current assessment was thus performed according to a revised content and methodological basis as compared with the previous BCP assessment carried out in 2004. The assessment of compliance with each CP is made on a qualitative basis to allow a judgment on whether the criteria are fulfilled in practice. Effective application of relevant laws and regulations is essential to provide indication that the criteria are met.

6. To assess compliance, the BCP Methodology uses a set of essential and additional assessment criteria for each principle. The essential criteria (EC) are the only elements on which to gauge full compliance with a core principle. The additional criteria (AC) are suggested best practices against which the Belgian authorities have agreed to be assessed. Additional criteria are commented on but are not reflected in the grading. The assessment of compliance with each principle is made on a qualitative basis. A four-part grading system is used: compliant; largely compliant; materially noncompliant; and noncompliant. This is explained below in the detailed assessment section.

7. The assessment team reviewed the framework of laws, rules, and guidance and held extensive meetings with officials of the NBB, and additional meetings with the banking sector participants. The team met the industry association representing banks in addition to a number of domestic and non-domestic institutions.

8. The team appreciated the very high quality of cooperation received from the authorities. The team extends its thanks to staff of the authorities who provided excellent cooperation, including extensive provision of documentation, at a time when many other initiatives related to domestic, European and global regulatory initiatives are in progress. 
9. The standards were evaluated in the context of the Belgian financial system's sophistication and complexity. It is important to note that Belgium has been assessed against the BCP as revised in 2006. This is significant for two reasons: (i) the revised BCP have a heightened focus on risk management, in comparison to the previous methodology, and its practice by supervised institutions and its assessment by the supervisory authority; and (ii) the standards are evaluated in the context of a financial system's sophistication and complexity.

\section{For completeness' sake, it should therefore be noted that the ratings assigned} during this assessment are not directly comparable to the ratings assigned in the previous Belgian FSAP, which was performed using the pre-2006 BCP Methodology. Differences may stem not only from the fact that the bar to measure the effectiveness of a supervisory framework was raised by the 2006 update of the BCP Methodology, but by lessons drawn from the financial crisis that may have a bearing on supervisory practices.

11. An assessment of compliance with the BCPs is not, and is not intended to be, an exact science. Reaching conclusions required judgments by the assessment team. ${ }^{1}$ Banking systems differ from one country to another, as do their domestic circumstances. Furthermore, banking activities are undergoing rapid change after the crisis, prompting the evolution of thinking on and practices for supervision. Nevertheless, by adhering to a common, agreed methodology, the assessment should provide the Belgian authorities with an internationally consistent measure of the quality of its banking supervision in relation to the revised Core Principles, which are internationally acknowledged as minimum standards.

12. To determine the observation of each principle, the assessment has made use of five categories: compliant; largely compliant, materially noncompliant, noncompliant, and nonapplicable. An assessment of "compliant" is given when all essential criteria are met without any significant deficiencies, including instances where the principle has been achieved by other means. A "largely compliant" assessment is given when there are only minor shortcomings, which do not raise serious concerns about the authority's ability to achieve the objective of the principle and there is clear intent to achieve full compliance with the principle within a prescribed period of time. A principle is considered to be "materially noncompliant" in case of severe shortcomings, despite the existence of formal rules and procedures and there is evidence that supervision has clearly not been effective, the practical implementation is weak or that the shortcomings are sufficient to raise doubts about the authority's ability to achieve compliance. A principle is assessed "noncompliant" if it is not substantially implemented, several essential criteria are not complied with, or supervision is manifestly ineffective. Finally, a category of "non applicable" is reserved (though not used) for those cases where the criteria would not relate to the Belgian authorities.

\footnotetext{
${ }^{1}$ The assessment team comprised Katharine Seal and Christopher Wilson, (both Senior Financial Sector Experts, IMF).
} 


\title{
INSTITUTIONAL AND MACROECONOMIC SETTING AND MARKET STRUCTURE OVERVIEW ${ }^{2}$
}

\begin{abstract}
13. The Belgian financial system is relatively large, concentrated, and interconnected. The banking system assets grew rapidly from 384 percent of GDP in 2000 to 470 percent of GDP in 2007, with growth largely driven by an expansion of investment banking activities financed through the surplus of domestic retail deposits and wholesale funding. Post 2008, an initial deleveraging significantly reduced the size of the banking sector to 310 percent of GDP in 2011, with a second wave of deleveraging, at a slower pace, currently underway. The system is concentrated with four dominant banking groups representing almost $3 / 4$ of consolidated system assets. Assets of foreign-owned banks account for more than half of the sector. The insurance sector is embedded in the predominant bancassurance model and dominated by a few conglomerates.
\end{abstract}

14. The $\mathbf{2 0 0 8}$ global financial crisis had a major impact on the Belgian banking sector. The rapid deterioration of access to market-based funding sources and declining capital positions forced banks to raise capital, shed assets, and appeal to the state for capital infusions. The Belgian state provided extensive funding and asset relief guarantees to the three largest banks. Since 2008, major banks have shed investment banking and asset management activities and shifted focus to more 'traditional' banking activities at home. Cross-border claims fell from 300 percent of GDP in 2008 to 58 percent of GDP in mid-2012. The largest remaining exposures are to the Czech Republic, France, the United Kingdom, and Ireland.

\section{After a short lived recovery, the export-oriented economic growth has slowed} significantly since the start of 2012 and is expected to stagnate in 2012-13. In addition to weak external demand in the European Union (main trading partner), domestic demand is also deteriorating, reflecting higher uncertainty, depressed consumer and business sentiment, and the pro-cyclical fiscal consolidation. The general government deficit is expected to fall below 3 percent of GDP in 2012 but given the growth prospects, the dynamics of the debt-to-GDP ratio remain uncertain. The government has initiated labor market and pension reforms in order to boost the employment rate and potential growth, but implementation is challenging and Belgium's competitiveness continues to fall. The deterioration of economic conditions has begun to push the unemployment rate upwards.

16. The links between banks and the Belgian sovereign have intensified due to the crisis. The total exposure of the banking sector to the federal government has increased substantially since 2008 and stood at 10 percent of banking sector assets in mid-2012, while the contingent fiscal liabilities stemming from the state aid to three banks currently amount to 16 percent of GDP. With exposures to the Belgian government at roughly more than half of all sovereign debt

\footnotetext{
${ }^{2}$ In FSAP/FSSA reports, this information will be contained in other parts of the FSAP report. Salient details, however, may be briefly restated for convenience.
} 
holdings of the sector and limited fiscal headroom for further support measures, fiscal consolidation remains critical to avoiding renewed strains on the banking sector, weakening of market confidence and increasing funding costs.

17. Domestic economic challenges and sovereign risk perceptions remain sources of continued uncertainty as the banking sector consolidates. Banks have struggled for profitability since the crisis, and structural costs remain high. A wide and stable deposit base has limited rollover risks and strategic re-orientation of the banking sector towards the domestic markets has prevented a disproportionate decline in credit supply. However, the weak economic environment and higher unemployment are likely to affect debt affordability, accentuated by the deflationary effect of deleveraging by households, banks and the government. Future increases in the interest rates and rising non-performing loan balances amidst weak economic conditions could pose a challenge for banks as they rebuild capital buffers and face implementation of higher regulatory requirements. There are also downside risks to asset quality, especially in banks' foreign subsidiaries, even though the overall level of impairments has remained relatively benign so far.

18. On the positive side, Tier 1 capital for the Belgian banking system has risen from 11.6 percent of risk-weighted assets in 2008 to 14.8 percent in mid 2012, and compares favorably to other major international banking systems. Actions by the authorities, market pressures, and experience from the crisis have led to banks aiming for stronger capital positions and enhanced short-term liquidity. A number of banks have made material progress in longer term programs to reduce their structural liquidity position through less reliance on wholesale funding. Stricter liquidity regulation by the NBB, spearheading future Basel III liquidity framework, has been conducive to greater focus on liquidity risk management, while the measures by the Eurosystem to support liquidity position of Euro area banks eased investors' concerns about their liquidity position.

19. As a direct result of the crisis, the regulatory and supervisory has been re-organized introducing a "twin peaks" model. The new architecture, which entered into force in April 2011, replaced the integrated regulator (the Commission Bancaire, Financiers et Assurances) and allocated the prudential supervision of financial institutions to the NBB and the responsibility for ensuring market conduct and consumer protection to the Financial Services and Markets Authority (FSMA). All bank and insurance supervision staff moved to the NBB.

\section{Crisis management and financial stability coordination}

\section{The NBB has the formal legal responsibility for coordinating the management of}

financial crises (NBB Organic Law, Article 36/3, section 1). Furthermore, it has the power to advise the Federal Government and the Federal Parliament on measures that are necessary or useful for financial stability. While the role of the Minister of Finance with respect to crisis management is not explicitly articulated in Belgian legislation, any actions necessary to protect financial stability proposed by the NBB under Article 57bis of the Banking Law require a Royal Decree, which will be deliberated upon by the Council of Ministers. Additionally, the NBB has a legal mandate for 
financial stability (Article 12 of the NBB Organic Law of 22 February 1998) including obligations to detect threats to financial stability, to submit recommendations to the government as necessary and to collaborate with the European Systemic Risk Board (ESRB). Furthermore, the NBB has specific powers in respect of systemic risks posed by systemic financial institutions. In particular, these powers include the ability to oppose strategic decisions or to impose specific measures (Article 36/3 section 2 of the Organic Law).

21. A formalized framework for financial stability coordination reflecting the transition to the Twin Peaks model has yet to be put in place. Following the implementation of the Twin Peaks model in Belgium, new arrangements between the NBB and the Ministry of Finance are yet to be agreed. Nevertheless, both the NBB and the Ministry remain bound by MoUs agreed in 2005 and 2008. Progress is being made in respect of agreeing MoUs between the NBB and the FSMA to formalize the modalities of effective exchange of information and cooperation. An agreement on surveillance of financial market infrastructure has been signed (October 2012) and a more general agreement of cooperation is under active discussion.

\section{A. Preconditions for Effective Banking Supervision}

\section{Belgium has a well developed public infrastructure supporting effective banking} supervision. Belgium has a complete system of business laws, consistently enforced. The Belgian legal system is based on civil law. The legislative branch is composed of a parliament with two chambers (Chamber and Senate). Belgium has a constitutional monarchy whereby the King is the head of state and of the executive branch. The judicial branch is independent with a hierarchy of courts, the most senior of which is the Court of Cassation, the supreme judicial court. There are two kinds of ordinary appeal: application to set aside or appeal the decision (Article 21(1) of the Judicial Code) and "special appeals." The ordinary appeals are dealt with by Court of Appeal, which has five courts whose territorial jurisdiction set out in the Constitution. The Court of Cassation considers "special appeals" the most common of which is whether the decisions referred to it contravene the law. A constitutional court was established in 1980. As a member of the EU, much domestic legislation, including banking regulation, derives from EU regulations, directives and decisions, which are frequently updated to keep pace with international standards.

\section{The Belgian accounting framework is established in law, and implemented through}

Royal Decree. In accordance with EU requirements, Belgium has adopted the IFRS accounting standards for listed companies and other consolidated accounts. Unconsolidated accounts must be prepared in accordance with Belgium Generally Accepted Accounting principles (BGAAP) as set out in the Royal Decree of 23 September 1992. The legal basis for the Belgian accounting framework is the Company law code and the specific supervisory laws applying to insurance and banking. The Commission for Accounting Principles is the statutory body charged with articulating Belgian General Accounting Principles. The NBB takes the Commission's role for accounting in the specific fields of insurance and banking. The Belgian Institute of Accountants (Institut des ExpertsComptables-IEC) has powers to regulate the profession. The Belgian auditing framework is also established in law and implemented through measures adopted by the Belgian Auditing Institute (Institut des Réviseurs d'Entreprises - IBR/IRE), which is a statutory body. The Institute is part of 
the audit oversight system and inspects audit firms in addition to its roles in training and continuous professional education. External auditors are licensed by the IBR/IRE and external auditors auditing a bank must also be accredited by the NBB (Article 50 of the Banking Act). Domestic auditing standards are prepared by the profession, reviewed by the High Council of the Institute and ultimately approved by the competent Minister. Rotation standards are set by the profession requiring a rotation after six years, either of the partner or, in the case of a sole practitioner, a transfer to another external auditor. From 2012 onwards audits of PIE's, have to be performed according to International Standards on Auditing as issued by the IAASB. The Institute is member of international organizations of auditors (FEE at European level and IFAC at the international level).

24. IFRS disclosures apply to all listed companies and all banks are subject to a range of disclosures requirements. Reports that must be issued include annual financial statements, management reports, or annual Risk Report as issued by banks. The NBB is planning to assess the consistency of Pillar 3 disclosures but no assessment has currently been completed beyond the assessment made by EBA, to which the NBB (and previously the CBFA) contributed as Belgian banking groups where included in the EBA assessment. Belgium has a regulated stock exchange (Euronext) and a secondary market that are subject to investor protection and governance rules, information disclosure requirements, and supervision processes to ensure their efficient functioning. Most of the requirements on both investor protection and information disclosure stem from European directives.

\section{Safety nets}

\section{All credit institutions established in Belgium must take part in a collective deposit} guarantee scheme financed by them. Consistent with EU legislation (Directive 94/19/EC) depositors are guaranteed up to a limit of $€ 100,000$ per depositor per credit institution. Legislation on the deposit guarantee system entered into force in 1994 and was successively modified in 1999 (establishing a deposit guarantee fund), 2008 (establishing a special guarantee fund), 2009 and 2011. The law provides gateways for the authorities that manage the Belgian deposit guarantee schemes to conclude cooperation agreements with foreign bodies and also creates a legal obligation for the NBB to inform the bodies, which manage the deposit guarantee scheme when it detects any problems likely to give rise to the intervention of these schemes (Article 110 bis2 of the Banking Law).

\section{The deposit guarantee scheme is jointly organized by two institutions: (a) the}

Protection Fund for Deposits and Financial Instruments ("PF") and (b) the Special Protection Fund for Deposits, Life Insurance and capital of cooperative companies ("SPF"). The creation of the SPF in 2008 was to create confidence by giving certainty to depositors that there will be sufficient funds to cover the claims of depositors in event of a failure of a. institution. Contributions to the SPF are risk based (solvency, liquidity and asset quality). Prior to 2009 contributions were paid to the PF but are currently suspended in the light of contributions that have had to be paid to the SPF since 2009. 
27. While the SPF is an administrative entity falling under the Ministry of Finance, the PF is an autonomous public institution (created under the law of 17 December 1998). The PF is administered by a management committee comprising equal numbers of representatives of the financial sector and the government. The Chairman and five Committee members are appointed by the Minister of Finance, two of whom are drawn from the NBB, with the remaining members being proposed by the banking and stockbroking industry. In case of a conflict of interests a Board member must recuse him or herself (Royal Decree of February 15, 1999).

28. DGS pay-out is triggered when a financial institution has been declared bankrupt by the Court or when the NBB has notified the DGS that a financial institution has failed to reimburse deposits to its clients. The reimbursement period is 20 working days. In the event of a failure, funds are to be drawn first from the PF, then from the SPF and should these funds be insufficient a supplementary advance will be made by the Ministry of Finance and recouped afterwards from contributing members of the deposit guarantee scheme. Following an advance of funds from the Ministry (i.e., government funds), any future contributions by industry participants to the SPF will be evenly distributed between direct repayment to the Ministry and the replenishment of the SPF's reserves. The reserves of the deposit guarantee scheme amounted to $€ 2$ billion at end-2012, with an estimated coverage ratio of around 0.6 percent of eligible deposits.

29. The PF may also, within the limits of its financial resources ( $€ 241$ million at June 30, 2012), take preventive action. The PF may thus assist in the liquidation, the financial reorganization or the resumption of business of a member institution. Such measures can only be taken if the cost of the operation does not exceed the amount of the total payout that would otherwise occur or if the operation is in the public interest of the financial system. Current legislation does not provide scope for preventive action by the SPF.

30. The Belgian authorities have established a Resolution Fund (RF) vesting it with powers to take preventative measures and to facilitate resolution procedures. The RF is established through the law of 28 December 2011 and implemented by Royal Decree of 23 February 2012. It is managed by the Caisse des dépôts et Consignations / Deposito en Consignatiekas, a special administration within the Ministry of Finance under the direct authority of the Minister of Finance, as is the Special Protection Fund. The RF can be used to finance measures such as preventative action or a bridge bank, total or partial transfer of assets and liabilities, a good/bad bank split. The RF is funded ex ante by annual financial stability contributions, which amount to 0.035 percent of the credit institution's total liabilities net of deposits eligible for deposit guarantee and of regulatory capital. The contributions are paid directly to the Ministry of Finance where they go to general revenue although a resolution reserve has been created using the contributions from the credit institution members of the Fund. Financial Stability Contributions (of €238 million) were paid in 2012 for the first time. No target level of reserves for the resolution fund has been set.

31. The NBB enjoys extensive early intervention and resolution powers. These powers are defined in articles 57 and 57 bis of the law of 22 March 1993 (see CP23). The NBB may appoint a special inspector, suspend the direct or indirect exercise of all or part of a credit institution's 
activities or prohibit these activities altogether, require a credit institution to replace a manager or a director, and revoke the authorization. In a resolution phase and when financial stability is threatened, the government, through a Royal Decree, may adopt measures providing for the transfer, sale of contributions relating to the assets, liabilities or one or more fields of activity or all or part of the rights and obligations of a credit institution, as well as securities and shares issued by such an institution.

\section{The NBB is the provider of Emergency Liquidity Assistance to credit institutions}

("ELA"). ELA is provided for under Article 14.4 of the Statutes of the ESCB. The extension of ELA is subject to consultation with the ECB Governing Council, which can prohibit ELA or subject ELA to conditions to avoid any interference or ELA operations with the ESCB's tasks and objectives. ELA granted by the NBB is automatically guaranteed by the State (Article 9 of the NBB Organic Law).

\section{B. Main Findings}

\section{Objectives independence, powers, transparence, and cooperation (CP1)}

33. The NBB has a clear legal power to conduct prudential supervision. Similarly the NBB has a legal mandate to detect threats to financial stability. The legal mandate does not, however, clarify the relationship between the discharge of the NBB's supervisory function and of its financial stability function and how the balance of priorities should be achieved should a potential conflict emerge. It is recommended that greater legal clarity be provided, should a revision to the NBB Organic Law be undertaken, and that the NBB should develop and publish a mission statement of its objectives irrespective of legal changes.

\section{The NBB has clear lines of accountability, transparency and separate funding when}

acting in its supervisory capacity. There is no indication in practice that there is any interference with the operational independence of the supervisor. Supervisory resources at the NBB are stretched and this is of concern given the continued stress within the financial system and given the importance of the program of enhancements to supervisory practices and processes that the NBB is urgently seeking to roll out. While there are no standard metrics in relation to adequate resourcing of the supervisory function, the NBB is encouraged to review its project plans very carefully to determine that it has robustly adequate resource required for the successful delivery of the multiple supervisory projects and day-to-day supervisory practice. The NBB should build contingency demands into this planning, not only because there may be demands arising from major EU developments such as the Banking Union, which is understood at the time of the mission to be likely to need to rely, perhaps heavily, on the resources of national authorities, rely but also from the potential for there to be crisis issues emerging in supervised institutions given continued elevated levels of systemic stress.

35. The NBB operates within a clear and balanced legal framework. The NBB Organic Law and Banking Law provide for authorization and ongoing standards of supervision. Additionally, the NBB enjoys a range of remedial measures that allow for an appropriate degree of proportionality in its approach to breaches of laws and regulations. It is noted that the drafting of 
Article 57 of the Banking Law usefully takes into consideration that there may be a necessity for swift action in urgent situations. The extensive powers to authorize the disposal of the assets or liabilities of an institution are balanced by the need to obtain ratification of such measures through a Royal Decree. Appropriate legal protections have been put in place in respect of banking supervision and supervisors.

36. The general framework for exchange of information is well articulated but coordination at a domestic level is yet to be fully put in place. The NBB's international relationships are supported by operational agreements and are working fluently. Domestic working level cooperation needs to be underpinned and promoted by an MoU to ensure the modalities of cooperation between the NBB and the FSMA. Amendments to the Twin Peaks Law to rectify drafting oversights in relation to the gateway for the exchange of information between the FSMA and the NBB, currently planned for the end of 2012, are also desirable and should be concluded.

\section{Licensing and structure (CPs 2-5)}

37. The legal framework for authorization, on-going standards for supervision and for permissible activities is clearly stated. The law provides that not only the NBB but the FSMA should have regard to the importance of ensuring that the public is not misled into placing deposits with institutions, which are not authorized for this purpose. The NBB is to be commended on its thorough and thoughtful review of fit and proper policies and practices, which ought to provide even greater clarity that fit and proper standards must be met on a continuous basis by relevant individuals and that the NBB can initiate an assessment at any moment. The widening of the formal scope of application of the fit and proper assessment to include key personnel such as the heads of compliance, internal audit and risk management, in cases where these individuals do not form part of the senior management is, similarly, good practice.

\section{The change of control of a credit institution and a major acquisition by a credit} institution is, broadly, well governed by the laws. There are some gaps that merit attention, however. While the change of control of an authorized institution is largely determined by EU law, it is to the NBB's credit that in its supervisory practice it is increasing its focus on the shareholding and ownership structure above the institution. The authorities are urged to remedy the lack of legal obligation for a credit institution to notify its supervisory authority of a material adverse development that may negatively affect the suitability of a major shareholder. With respect to major acquisition the NBB has comprehensive legal provisions surrounding the governance and scrutiny of major acquisitions by its supervised firms. In particular the powers to pre-approve strategic decisions taken by the systemically relevant institutions provide a great deal of protection. For non-systemic firms, however, it is recommended that the NBB establish either prenotification or pre-approval thresholds for acquisitions in non-financial entities.

\section{Prudential regulation and requirements (CPs 6-18)}


39. Belgium banks have undergone considerable stress over the last several years and, as a result, have increased their capital, importantly the quality of capital in CET1. The major bank Tier 1 capital ratios range between 11.5 percent and 20.6 percent for the larger systemically important banks as at March 2012. The capital ratios across this group of banks demonstrate a high composition of CET1, which has been gradually increasing, albeit with severe stress at stages from the crisis requiring state intervention and support. The quality of the capital base has been improving with a run off of Tier 2 instruments in anticipation of the implementation of Basel III. Nonetheless, increased minimum capital adequacy requirements under BIII will continue to be challenging for some banks in the context of lower internal profit generation.

40. The NBB's approach to Pillar 2 is well developed using a scorecard as the primary tool for risk analysis, taking into account qualitative and quantitative measures. At least on an annual basis, the NBB determines the minimum capital adequacy requirements for all banks on a forward looking basis. The SREP and ICAAP analysis are important inputs into the process and, if available, outputs from banks' economic capital models. Stress testing is also taken into account as to ascertain whether the bank is able to maintain capital buffers under stress conditions.

41. Senior management of the bank is required to submit an annual self assessment of the control environment to the NBB. The external auditor will provide a report, which is a factual evaluation of management's self assessment but is on its own not a positive assurance regarding the design and effectiveness of controls. As a result, the external auditors report will not necessarily identify whether there is hidden build-up of risks or provide a positive assurance as to the quality of risk management. In the absence of an on-site review by the NBB, too much reliance should not be placed on this report as a mechanism to identify the build-up of risks. In practice NBB uses the input from the external auditor in combination with other supervisory activities, such as the ICAAP, on-site reviews and discussions with the Board etc.

\section{Annual meetings with the full Board of Directors should form an integral} component of the NBB's standard supervision practice. In developing a minimum set of supervisory activities to be performed on a set periodic basis, annual meetings with the full Board (including non-executive independent directors) should be mandatory for all banks. The meeting will help the supervisor assess the role of the Board in overseeing management to ensure that the policies, processes and systems are implemented effectively at all decision levels. Whereas current supervisory practices provide already for frequent meetings between supervisory staff and Board members, there is room for formalizing the minimum set of supervisory activities to be performed on a periodic basis in this respect.

43. The limits regarding large exposures have been strengthened recently. An institution shall not incur an exposure, after taking into account the effect of the eligible credit risk mitigation techniques, to a client (counterparty) or a group of connected clients (counterparties) the value of which exceeds 25 percent of its own funds. Following the European Directive text (as modified by Directive 2009/111/EC), where the client is an institution, the value shall not exceed 25 percent of the credit institution's own funds or EUR 150 million, whichever is the higher, provided that the sum of exposure values after taking into account eligible credit risk mitigation 
techniques to all connected clients that are not institutions does not exceed 25 percent of the credit institution's own funds. Where the amount of EUR 150 million is higher than 25 percent of the own funds, the value of the exposure, after credit risk mitigation, shall not exceed a reasonable limit in terms of the credit institution's own fund. That limit shall be determined by credit institutions, consistently with the policies and procedures to address and control concentration risk and shall not be higher than 100 percent of the credit institution's own funds. This means concretely that a more lenient large exposure limit may be accepted by authorities for smaller credit institutions (i.e., having own funds below EUR 600 million).

44. Liquidity regime is well embedded. The systemic banks need to report liquidity on a daily basis in addition to meeting a one week and one month liquidity stress test. The objective of the stress test is to ensure the bank is able to meet predefined liquidity buffers o survive a shortdated stress. While the definition of eligible liquids is broader than the Basel LCR definition, the run-off assumptions for liabilities are more stringent. The stress test was introduced at the start of 2009 as an observation ratio with full implementation from 2011. The introduction of a liquidity stress test will help smooth the transition to comply with the LCR for banks when implemented in 2015.

45. Specific guidance has been issued regarding sound management of outsourcing, business continuity management and financial services provided by the internet. The NBB has a dedicated team of eight IT specialists. While all credit institutions are required to perform regular business continuity practices and disaster recovery testing, the NBB will not necessarily receive the detailed results of that testing. The NBB should strengthen the framework for operational risk monitoring by requiring all credit institutions to certify a certain level of resilience on an annual basis, and require immediate reporting of a breach of that level, particularly if bank is systemic.

\section{The requirements for managing interest rate risk in the banking book are well} established in the regulatory framework. The NBB has made strong efforts to implement new standards and has embedded interest rate risk in its core work. Interest rate risk stress test ratios require banks to hold sufficient capital to cover economic value losses related to adverse structural interest rate changes prescribed by the NBB. While the ratios provide a consistent measure of interest rate risk across banks, the ratios do not always fully capture bank specific risks. When evaluating minimum capital ratios, interest rate risk is taken into account as a Pillar 2 risk.

\section{Methods of ongoing banking supervision (CPs 19-21)}

\section{The supervisory staff of the NBB are conducting excellent quality risk based} supervision both on and off-site. The NBB has put in place a sound analytical process that it is in the process of refreshing and deepening in terms of analytical insight. These revisions will contribute further to the global risk assessments for groups and it will be valuable if the refinements can further emphasize the forward looking elements of the assessments. Relatively 
unusually, the NBB shares the detailed risk assessment with the institutions concerned and has found this approach to have a constructive and beneficial effect. The greater power of risk discrimination in the new tools should further support the dialogue between the institutions and the supervisors therefore. Continued incorporation of insurance risk within the global group risk assessments is important and should also be enhanced, as planned. In terms of on-site supervision the NBB has restructured its resources and put in place effective coordination with the off-site teams.

\section{The NBB applies a comprehensive supervisory program to the systemic firms but} must ensure that "globally balanced supervisory planning" covers all supervised firms. The NBB must put in place a risk based approach to its supervisory process to ensure that each institution systematically receives the appropriate intensity of supervisory attention proportionate to its profile. Such a plan also needs to provide a structured framework to guide decision making in terms of which actions should be postponed or performed less frequently, and which institutions should be affected when new or urgent priorities emerge that demand the reallocation of scarce supervisory resource. Further, the plan should clarify the minimum frequency with which standard (and as necessary) non-standard reporting must be made to the NBB Board for information or decision making. The NBB has already initiated a range of projects, both analytical and IT based, that will be invaluable in delivering this objective. It will be important to ensure the successful completion of such projects, while recognizing that project management is especially challenging in the current environment of elevated systemic risks and the likely introduction of structural changes such as the Banking Union.

\section{Accounting and disclosure (CP 22)}

49. In Belgium, the external auditor of a bank is accredited by the NBB. In the Belgium model, the external auditor is seen as a 'collaborator' of banking supervision. The external auditor is accredited directly by the NBB after satisfying minimum expectations regarding independence, experience, competence and adequate organization. The external auditor will provide an audit opinion on the financial accounts (six monthly and annually). The auditor will also provide an opinion regarding the self assessment performed by management annually on the internal control environment and on the reliability of prudential returns.

50. Under NBB rules, banks are required to report on a solo and, if part of a group, consolidated basis. Belgium accounting rules (Belgium GAAP) apply on a solo basis and IFRS for consolidated consolidated basis if they have to produce consolidated accounts according to EU directives. Banks submit quarterly prudential returns of key data such as capital adequacy, balance sheet, earnings etc. Liquidity is reported more frequently on a monthly basis. However, concentration risk is only reported annually and interest rate risk data is submitted with a lag of two and half month after the reporting date making an integrated and comprehensive offsite analysis more challenging. Aligning reporting requirements for all key data elements will enhance the quality of offsite supervision. The NBB has a project in place to consider prudential reporting.

\section{Corrective and remedial powers of supervisors (CP 23)}


51. The NBB enjoys a broad range of powers for corrective and remedial measures and there is evidence that the NBB is able and ready to use such remedies. Moreover, the strong powers open to the NBB have clearly meant that there are occasions where the supervisory authority has been able to use suasion rather than needing to resort to legal remedies in the first instance. The NBB has indicated it is at present examining the possibility of making its disciplinary powers more graduated and proportionate to the severity of the offence committed by the supervised institution.

\section{Consolidated and cross border banking supervision (CPs 24-25)}

52. The NBB has the necessary legal powers and has implemented the necessary regulatory structure to facilitate the practice of consolidated supervision. Given the significance of cross border activities for the systemic groups in Belgium, the NBB has focused on work within the EU supervisory colleges to ensure effective group oversight. The NBB is actively using the college environment to create opportunities to test out the quality of risk focused management within groups by their own management as well as to ensure an adequate distribution of capital within the group. In terms of further developing its practices, the NBB is encouraged to execute plans to enhance governance requirements for groups by stating more explicitly what is expected of the parent company in respect of coordinating and controlling the group in a holistic way. One particular challenge is to ensure that non-banking and, as appropriate, non-financial risks within the group are fully understood, even though these risks may appear to present only a small part of the group. The ability to communicate and cooperate effectively with all domestic regulators as well as international authorities is critical to this task. It is therefore recommended (as also noted in CP 1(6)) that the NBB and the FSMA finalize the MoU setting out the modalities of cooperation as foreseen in the Twin Peaks legislation.

\section{The NBB places great value on and is strongly motivated to contribute to and} participate in home-host relationships as fully and as effectively as possible. Cooperation arrangements and MoUs are in place with all relevant jurisdictions. Home and host relationships are critical to the successful supervisory oversight of the financial system in Belgium. While EU legislation imposes requirements including joint assessment and decision making processes on EU supervisory colleges, the quality of execution depends on the supervisory authorities. The depth and quality of information sharing, the joint projects undertaken, documentation of exchanges of views between authorities and actions taken attest to a maturing dialogue between supervisors, which should serve the NBB well and for which the NBB's own attitude should be given significant credit. Table 1 below offers a principle-by-principle summary of the assessment results. 
Table 1. Summary Compliance with the Basel Core Principles-Detailed Assessments

\begin{tabular}{|c|c|c|}
\hline Core Principle & Grading & Comments \\
\hline \multicolumn{3}{|l|}{$\begin{array}{l}\text { 1. Objectives, independence, powers, } \\
\text { transparency, and cooperation }\end{array}$} \\
\hline 1.1 Responsibilities and objectives & C & $\begin{array}{l}\text { Legal mandate to supervise is in place but } \\
\text { there could be greater clarity and transparency } \\
\text { in terms of the relationship between the } \\
\text { supervisory and financial stability goals of the } \\
\text { NBB. }\end{array}$ \\
\hline $\begin{array}{l}1.2 \text { Independence, accountability and } \\
\text { transparency }\end{array}$ & LC & $\begin{array}{l}\text { It is not mandatory for the reasons for the } \\
\text { dismissal of the Governor of the NBB to be } \\
\text { publicly disclosed. Staff resources are over- } \\
\text { stretched at a time of elevated stress so } \\
\text { capacity to respond to deteriorating conditions } \\
\text { may be jeopardized. The limited rule making } \\
\text { powers are subject to potential veto by the } \\
\text { government. }\end{array}$ \\
\hline 1.3 Legal framework & C & $\begin{array}{l}\text { The NBB operates within a legal framework } \\
\text { that provides for authorization and ongoing } \\
\text { standards of supervision. See also CP } 1.2\end{array}$ \\
\hline 1.4 Legal powers & C & $\begin{array}{l}\text { A suitable legal framework for banking } \\
\text { supervision is in place including a broad range } \\
\text { of powers for the supervisor. }\end{array}$ \\
\hline 1.5 Legal protection & C & $\begin{array}{l}\text { Appropriate legal protections have been put in } \\
\text { place in respect of banking supervision and } \\
\text { supervisors. }\end{array}$ \\
\hline 1.6 Cooperation & C & $\begin{array}{l}\text { The general framework for exchange of } \\
\text { information is well articulated and there is } \\
\text { evidence, based on the assessors' reviews of } \\
\text { files, that it is operational in practice. The } \\
\text { modalities of cooperation between the NBB } \\
\text { and the FSMA need to be finalized and made } \\
\text { fully operational. }\end{array}$ \\
\hline 2. Permissible activities & C & $\begin{array}{l}\text { The laws provide clear definitions and not only } \\
\text { the NBB but the FSMA, in their activities, have } \\
\text { regard to the importance of ensuring that the } \\
\text { public is not misled into placing deposits with } \\
\text { institutions, which are not authorized for this } \\
\text { purpose. }\end{array}$ \\
\hline 3. Licensing criteria & C & $\begin{array}{l}\text { The NBB has a sound practice in place but has } \\
\text { been reviewing its policies and practices } \\
\text { around its regime for assessing "fit and } \\
\text { proper." }\end{array}$ \\
\hline 4. Transfer of significant ownership & C & $\begin{array}{l}\text { The NBB's application of policies and } \\
\text { procedures in this area are comprehensive and } \\
\text { there is an increasing focus on looking } \\
\text { "upwards" through the shareholding and } \\
\text { ownership structure above the institution. }\end{array}$ \\
\hline
\end{tabular}




\begin{tabular}{|c|c|c|}
\hline 5. Major acquisitions & LC & $\begin{array}{l}\text { The requirements of this principle are met in } \\
\text { relation to the systemic institutions, due to the } \\
\text { NBB's powers to object to strategic decisions } \\
\text { made by such firms. Non-systemic firms have } \\
\text { the potential to undertake a major acquisition } \\
\text { in a non-financial sector without either pre- } \\
\text { notification or pre-approval requirements } \\
\text { being in place, however. }\end{array}$ \\
\hline 6. Capital adequacy & LC & $\begin{array}{l}\text { The current approach to the deduction for } \\
\text { investment in insurance subsidiaries is to } \\
\text { deduct } 100 \text { percent from Total Capital. While } \\
\text { this approach is consistent with the CRD, it is } \\
\text { not, consistent with Basel II for a 50:50 } \\
\text { deduction from Tier } 1 \text { and Tier } 2 \text {. The } \\
\text { application of this deduction from Total Capital } \\
\text { is applicable to Belgium's largest domestic } \\
\text { consolidated banks. This treatment will be } \\
\text { modified to align with the Basel II as of } 1 \\
\text { January 2013. It is the intention of the NBB to } \\
\text { apply the deduction of participations in } \\
\text { insurance companies pursuant to the Basel III } \\
\text { framework in the future. } \\
\text { An aspect of the Belgium banking sector that } \\
\text { was problematic during the crisis involved the } \\
\text { practice of banks granting credit to } \\
\text { shareholders to subscribe to the capital of the } \\
\text { bank where repayment of the loan depended } \\
\text { on the proceeds the shareholder received from } \\
\text { the capital instrument. The implication of this } \\
\text { practice is that capital is not able to absorb } \\
\text { losses and cannot be classified as 'paid up' as } \\
\text { per the definition of capital. The other } \\
\text { dimension of this issue is that published capital } \\
\text { adequacy ratios of banks are artificially } \\
\text { inflated, which weakens the transparency of } \\
\text { the true loss absorbency of capital. } \\
\text { We acknowledge that the own funds } \\
\text { regulation has been amended to address this } \\
\text { issue with a transition period commencing } 1 \\
\text { January } 2014 \text {, although at the time of the } \\
\text { mission, the capital base included these } \\
\text { amounts. }\end{array}$ \\
\hline
\end{tabular}




\begin{tabular}{|c|c|c|}
\hline 7. Risk management process & LC & $\begin{array}{l}\text { Many of the criteria in CP7 require the } \\
\text { supervisor to assess the Board's involvement in } \\
\text { the risk management function. Indeed, the } \\
\text { Principle focuses on Board oversight of risk } \\
\text { management policies and processes. While the } \\
\text { regulations require Boards to approve risk } \\
\text { management strategies and the ICAAP, the } \\
\text { supervisory assessment of the Board's } \\
\text { involvement and understanding of risks and } \\
\text { risk management will not necessarily involve } \\
\text { direct engagement with the full Board } \\
\text { (independent non-executive directors), even } \\
\text { for larger systemic banks on at least an annual } \\
\text { frequency. Without direct engagement with } \\
\text { the full Board to challenge their appreciation } \\
\text { of the risks, the implementation of risk } \\
\text { management and adequacy of capital, it is } \\
\text { difficult to see how the supervisor is able to } \\
\text { arrive at an accurate, timely and } \\
\text { comprehensive view of the Board's oversight } \\
\text { of risk management. }\end{array}$ \\
\hline 8. Credit risk & LC & $\begin{array}{l}\text { There is no requirement in the regulations for } \\
\text { major credit risk exposures over a certain } \\
\text { amount or percentage of the bank's own } \\
\text { funds, to be decided by the bank's senior } \\
\text { management or Board. } \\
\text { Without this requirement, critical credit } \\
\text { decisions can, in practical terms, be made by } \\
\text { officers of the bank that might not be suitably } \\
\text { informed of all risks. An effective delegation } \\
\text { structure will strengthen the risk management } \\
\text { framework to ensure that credit decisions are } \\
\text { only taken at an appropriate level. This will also } \\
\text { help to avoid unnecessary conflicts of interest, } \\
\text { which might arise in relation to the granting of } \\
\text { credit. While a conflicts of interest policy is } \\
\text { required by the regulations, it might prove } \\
\text { inadequate to mitigate this risk. }\end{array}$ \\
\hline 9. Problem assets, provisions, and reserves & C & $\begin{array}{l}\text { Accounting standards govern the preparation } \\
\text { and presentation of general purpose, publicly } \\
\text { disclosed financial statements by banks. }\end{array}$ \\
\hline
\end{tabular}




\begin{tabular}{|c|c|c|}
\hline 10. Large exposure limits & LC & $\begin{array}{l}\text { The LE regime provides for concessions for } \\
\text { smaller banks to exceed the } 25 \text { percent limit } \\
\text { up to } 100 \text { percent own funds if the exposure is } \\
\text { less than } 150 \mathrm{mn} \text { euro. In the event of a default } \\
\text { of the counterparty, smaller banks are typically } \\
\text { less able to raise additional equity and in some } \\
\text { cases, may not have degree of sophistication } \\
\text { in reporting and risk management (such as real } \\
\text { time exposure reporting) to make timely } \\
\text { decisions. CRM can reduce the exposure even } \\
\text { at the } 100 \text { percent threshold which means in } \\
\text { practice, the gross exposure to a single } \\
\text { counterparty can exceed } 100 \text { percent own } \\
\text { funds, which represents significant } \\
\text { concentration risk. }\end{array}$ \\
\hline 11. Exposure to related parties & C & $\begin{array}{l}\text { The prudential requirements regarding } \\
\text { exposures to related parties is not established } \\
\text { in a single regulatory requirement but a } \\
\text { number of regulations that act to mitigate this } \\
\text { risk. An integrated process for the } \\
\text { identification, monitoring and reporting of } \\
\text { exposures to related parties approved by the } \\
\text { board is not explicitly provided for in the } \\
\text { regulations. }\end{array}$ \\
\hline 12. Country and transfer risks & LC & $\begin{array}{l}\text { The NBB has not issued specific guidance on } \\
\text { country and transfer risk (other than guidance } \\
\text { relating to credit risk and concentration risk in } \\
\text { general), and not imposed any more specific } \\
\text { reserves against such risks as required by the } \\
\text { Principle. }\end{array}$ \\
\hline 13. Market risks & C & $\begin{array}{l}\text { The regulatory framework has been revised to } \\
\text { take account of the Basel II.5 enhancements. } \\
\text { Since the crisis, the main trading activities of } \\
\text { Belgium banks have declined to consist mainly } \\
\text { of the management of customer demand. VaR } \\
\text { is the main risk management tool used by } \\
\text { banks to limit positions. }\end{array}$ \\
\hline 14. Liquidity risk & C & $\begin{array}{l}\text { The regulatory requirements for liquidity risk } \\
\text { are relatively well advanced with a quantitative } \\
\text { test similar to the Basel LCR in place since } \\
2011 \text {. Daily reporting for larger systemic banks } \\
\text { is robust. Follow-up of the self assessment } \\
\text { process has not been conduced across all } \\
\text { banks in the sector. }\end{array}$ \\
\hline
\end{tabular}




\begin{tabular}{|c|c|c|}
\hline 15. Operational risk & C & $\begin{array}{l}\text { The supervisor uses a number of tools for } \\
\text { identifying and assessing operational risk. The } \\
\text { frequency of on-site assessments are risk- } \\
\text { based and for the large banking groups, } \\
\text { performed on an annual basis. For medium } \\
\text { sized and small banks, the frequency of on-site } \\
\text { inspections varies between one and four years. } \\
\text { Quantitative and qualitative information is } \\
\text { included in offsite analysis and used in the } \\
\text { scorecarding process. }\end{array}$ \\
\hline 16. Interest rate risk in the banking book & $C$ & $\begin{array}{l}\text { The prudential requirements for managing } \\
\text { interest rate risk in the banking book are well } \\
\text { established in the regulatory framework. The } \\
\text { NBB has made strong efforts to implement } \\
\text { new standards and has embedded interest rate } \\
\text { risk in its core work. }\end{array}$ \\
\hline 17. Internal control and audit & LC & $\begin{array}{l}\text { The supervisory model places reliance on the } \\
\text { credit institution and the external auditor to } \\
\text { verify the effectiveness of the control } \\
\text { environment. The frequency, depth and } \\
\text { comprehensiveness of the supervisors testing } \\
\text { of the internal control environment can be } \\
\text { enhanced. }\end{array}$ \\
\hline 18. Abuse of financial services & LC & $\begin{array}{l}\text { The last FATFs Mutual Evaluation Report was } \\
\text { made in of June } 2005 \text {, with another scheduled } \\
\text { for } 2014 \text {. In the } 2005 \text { report, the level of } \\
\text { compliance of the AML/CFT regulation and } \\
\text { guidance for the financial sector with the } \\
\text { relevant Recommendations appears to be very } \\
\text { satisfactory. } \\
\text { The NBB use a range of supervisory tools to } \\
\text { monitor and supervise this risk. There was } \\
\text { overall not a systematic process governing } \\
\text { how the compliance requirements fit into the } \\
\text { supervisory framework, applied across the } \\
\text { population of banks. } \\
\text { Several criteria in Principle } 18 \text { require the } \\
\text { supervisor to confirm that banks have } \\
\text { sufficient controls and systems in place for } \\
\text { preventing, identifying and reporting potential } \\
\text { abuses of financial services, including money } \\
\text { laundering etc. It was not sufficiently } \\
\text { evidenced that the supervisor had a systematic } \\
\text { process to verify adequacy of risk management } \\
\text { across the population of banks. }\end{array}$ \\
\hline
\end{tabular}




\begin{tabular}{|c|c|c|}
\hline 19. Supervisory approach & $C$ & $\begin{array}{l}\text { The NBB has put in place a sound analytical } \\
\text { process that it is in the process of refreshing } \\
\text { and deepening both in terms of analytical } \\
\text { insight as well as enhancing the underpinning } \\
\text { IT capabilities. The new supervisory tools } \\
\text { ought to support a more forward looking } \\
\text { analysis and also integrate analysis of } \\
\text { insurance risk into the global risk assessment } \\
\text { of groups. }\end{array}$ \\
\hline 20. Supervisory techniques & LC & $\begin{array}{l}\text { The NBB applies a comprehensive supervisory } \\
\text { program to systemic firms. At present, } \\
\text { however, there is no process to identify the } \\
\text { level of supervisory intensity that is } \\
\text { proportionate for the non-systemic firms. } \\
\text { Within the group of non-systemic firms, risk } \\
\text { profiles vary and the minimum levels of } \\
\text { adequate supervisory attention will also vary. } \\
\text { The NBB needs to be certain that it has } \\
\text { correctly identified these minimum levels of } \\
\text { supervisory activity and is capable of } \\
\text { monitoring and updating its plans as } \\
\text { circumstances change. The NBB is aware of this } \\
\text { dimension and has already embarked on } \\
\text { multiple projects that will support a successful } \\
\text { outcome. }\end{array}$ \\
\hline 21. Supervisory reporting & C & $\begin{array}{l}\text { Belgium has a well developed system for } \\
\text { assessing prudential returns as part of its } \\
\text { offsite analysis. Financial analysts within the } \\
\text { integrated supervisory teams, assess prudential } \\
\text { returns, mainly on a quarterly basis, the results } \\
\text { of which feed into the team meetings, which } \\
\text { discuss peer comparisons and suggested } \\
\text { outcomes for future action. }\end{array}$ \\
\hline 22. Accounting and disclosure & C & $\begin{array}{l}\text { BGAAP applies at a solo level and IFRS for } \\
\text { consolidated accounts. There is no concrete } \\
\text { plan to harmonize accounting methodologies. } \\
\text { The different treatment for valuations might } \\
\text { create some lack of consistency in comparing } \\
\text { risk profiles. }\end{array}$ \\
\hline $\begin{array}{l}\text { 23. Corrective and remedial powers of } \\
\text { supervisors }\end{array}$ & C & $\begin{array}{l}\text { The NBB has wide powers of remedial and } \\
\text { corrective action and there is evidence that it is } \\
\text { prepared to use such powers, even if moral } \\
\text { suasion has been effective upon occasion. } \\
\text { Planned legal changes to permit the NBB } \\
\text { Board to apply periodic penalty payments will } \\
\text { be a potentially useful additional power. }\end{array}$ \\
\hline
\end{tabular}




\begin{tabular}{|l|l|l|}
\hline 24. Consolidated supervision & N & $\begin{array}{l}\text { The NBB has the necessary legal powers and } \\
\text { has implemented the necessary regulatory } \\
\text { structure to facilitate the practice of } \\
\text { consolidated supervision. The NBB has } \\
\text { continued to develop its working relationships } \\
\text { with key supervisory authorities to ensure the } \\
\text { quality of group oversight of the systemic } \\
\text { firms in particular. }\end{array}$ \\
\hline 25. Home-host relationships & C & $\begin{array}{l}\text { The NBB places great value on home-host } \\
\text { relationships. Cooperation agreements and } \\
\text { MoUs have been put in place with all relevant } \\
\text { authorities and an increasingly mature } \\
\text { dialogue of exchange of information and joint } \\
\text { activities is being undertaken. }\end{array}$ \\
\hline
\end{tabular}

Aggregate: Compliant (C) $-21^{3}$, Largely compliant (LC) - 9, Materially noncompliant (MNC) - zero, Noncompliant (NC) - None (note: CP 1 is divided into six component for this analysis.)

\section{Recommended action plan and authorities' response}

\section{Recommended action plan}

Table 2 lists the suggested steps for improving compliance. Recommendations are proposed on a prioritized basis.

\footnotetext{
${ }^{3}$ The grading in respect of CP18 (abuse of financial services) is provisional as there was insufficient detail available to make a comprehensive assessment at the time of the review.
} 
Table 2. Recommended Action Plan to Improve Compliance with the Basel Core Principles

\begin{tabular}{|c|c|}
\hline Reference Principle & Recommended Action \\
\hline 1.2 Independence, accountability and transparency & $\begin{array}{l}\text { The reasons for the dismissal of the Governor of the } \\
\text { NBB must be publicly disclosed. Adequacy of staff } \\
\text { resources need to be reviewed. }\end{array}$ \\
\hline 4. Transfer of significant ownership & $\begin{array}{l}\text { The authorities are urged to remedy the lack of legal } \\
\text { obligation for a credit institution to notify its } \\
\text { supervisory authority of a material adverse } \\
\text { development that may negatively affect the suitability } \\
\text { of a major shareholder. }\end{array}$ \\
\hline 5. Major acquisitions & $\begin{array}{l}\text { Laws or regulations should be amended to ensure that } \\
\text { the NBB has the right of pre-approval of a major } \\
\text { acquisition by a credit institution in the non-financial } \\
\text { sector. }\end{array}$ \\
\hline 7. Risk Management & $\begin{array}{l}\text { Continue with the update of the Circular on Internal } \\
\text { Governance. Emphasis on role of Board. Develop a } \\
\text { comprehensive risk management standard, which } \\
\text { articulates the NBB's minimum expectations for risk } \\
\text { management for banks and across a group (leverage off } \\
\text { international efforts). } \\
\text { Develop a standard supervision program for all banks } \\
\text { according to risk profile. Program The baseline } \\
\text { supervisory program should include such activities as } \\
\text { meetings with the non-executive directors (at least } \\
\text { annually), review of Board minutes, onsite review testing } \\
\text { controls and risk management and a meeting with the } \\
\text { external auditor. Minimum supervision program is linked } \\
\text { to the risk scorecard. } \\
\text { When updating the Internal Governance Circular } \\
\text { consider including a section for the Internal Audit } \\
\text { function to formally report to the Audit Committee to } \\
\text { ensure functional and operational independence. } \\
\text { Suggest the internal Governance Circular requires major } \\
\text { policies when approved by the board to be submitted to } \\
\text { the NBB. While this might happen in practice, it } \\
\text { formalizes the expectation. } \\
\text { models (Pillar } 1 \text { ) to be assessed on a regular basis. The } \\
\text { assessment would consider results of annual tests, audit } \\
\text { findings etc. }\end{array}$ \\
\hline
\end{tabular}




\begin{tabular}{|c|c|}
\hline 16. Interest rate risk in the banking book & $\begin{array}{l}\text { The program could be further enhanced as follows: } \\
\text { Write a single regulation to replace multiple } \\
\text { rules texts. Include requirements for stress } \\
\text { testing, a limit framework that reflects risk } \\
\text { appetite. } \\
\text { Strengthen the regulatory framework with a } \\
\text { requirement for a functional and operational } \\
\text { separation of markets and treasury function. } \\
\text { Consider an Asset Liability Committee for all } \\
\text { credit institutions, which will enhance the } \\
\text { quality, timeliness and management of this risk. } \\
\text { Extend cross-sectoral analysis to a greater } \\
\text { number of banks. Improve the identification of } \\
\text { outliers and strengthen the transfer of skills to } \\
\text { supervisor. }\end{array}$ \\
\hline 17. Internal control and audit & $\begin{array}{l}\text { Consider obtaining a positive assurance from the } \\
\text { external auditor as to the design and effectiveness of } \\
\text { controls. This report would extend beyond the scope of } \\
\text { the current engagement of the external auditor, which } \\
\text { is an assessment of the process and documentation of } \\
\text { the self assessment performed by management. }\end{array}$ \\
\hline 20. Supervisory techniques & $\begin{array}{l}\text { The NBB should put in place a systematic supervisory } \\
\text { process to ensure that each institution systematically } \\
\text { receives the appropriate intensity of supervisory } \\
\text { attention proportionate to its profile. }\end{array}$ \\
\hline 21. Supervisory reporting & $\begin{array}{l}\text { Reporting dates for prudential returns, in some } \\
\text { instances lag public reporting. Furthermore, some } \\
\text { prudential returns are submitted only annually such as } \\
\text { concentration risk. Align the reporting dates so that } \\
\text { returns are submitted more timely and more } \\
\text { consistently to enable integrated and timely financial } \\
\text { analysis. }\end{array}$ \\
\hline
\end{tabular}




\section{Authorities' Response to the Assessment}

54. The NBB can subscribe to the general conclusions and the main findings as laid down in this report. The NBB is satisfied with the overall high level of compliance with the 2006 Banking Core Principles and appreciates that recognition has been given to the challenging environment is which the NBB currently performs its supervisory tasks. The challenges stem from the continued crisis conditions and the relatively recent integration of prudential supervision into the NBB, formerly a task performed by the CBFA. During the mission, the NBB had the opportunity to explain the initiatives/reforms underway as a response to these challenges and to indicate how well advanced some of them already are. Discussions with the IMF were thus also a fruitful sounding board for the NBB and we will take into account the advice and recommendations to continue work in this respect.

55. For some of the Banking Core Principles, mainly those for which the NBB received a downgrade, we provide here some more extensive comments to the IMF's assessment or we indicate our future plans to meet the IMF's recommendations.

\section{BCP 1: Objectives, independence, powers, transparency, and cooperation}

56. The NBB will reconsider the adequacy of the supervisory resources in order to achieve the appropriate supervisory intensity and effectiveness in the course of 2013.

\section{BCP 4: Transfer of significant ownership}

57. The obligation for a credit institution to inform the supervisory authority of any material adverse development (affecting the criteria under which the assessment of the suitability of a major shareholder is made) will be provided soon, on the occasion of the next Banking Law's modification.

\section{BCP 5: Major acquisitions}

58. The right of pre-approval by the NBB of a major acquisition by a credit institution in the nonfinancial sector will be provided soon, on the occasion of the next Banking Law's modification.

\section{BCP 6: Capital adequacy}

59. We agree with the conclusion relating to the deduction of insurance company but underline that the regulation will be adapted as from 1 January 2013 on.

60. With regard to the deduction of credits to shareholders that have been used to subscribe capital instruments, we underline that the current regulation is fully in line with the Basel 3 framework and notably the eligibility criterion 11 for common equity tier 1 which states that "the instrument is directly issued and paid-in and the bank can not directly or indirectly have funded the purchase of the instrument. 
61. This last criterion is new with regard to the conditions that the instrument must be directly issued and the bank can not directly or indirectly have funded the purchase of the instrument. As these conditions are new, the NBB has introduced a transitional measure for the deduction of existing credits at the end of December 2010 in line with the transitional measures of the Basel 3 framework. In the meantime, existing credits that are not deducted from own funds are taken into consideration in the pillar 2 decision relating to capital add-ons set by NBB, meaning that the full amount of these credits must be covered by common equity tier 1 . All new credits that have been granted since end 2010 have been deducted from common equity tier 1 .

62. With regard to the transparency issue, we will follow the new European regulation transposing the Basel 3 framework that requires each bank to disclose the impact of any transitional measures to the market (see article 470 of the current draft CCR) from the entry into force of this regulation and the guidelines that EBA will issue with regard to disclosure on own funds (see EBA consultation paper EBA/CP2012/04 Consultation paper on draft implementing standards on disclosure for own funds).

63. In addition to the Basel criterion 11, the current Belgian regulation provides also for the deduction of credits to shareholders when they are not granted at market conditions and when there is no evidence that the shareholders have sufficient revenues on an ongoing basis, other than the distributions on the capital instruments held, to support the payment of interest and repayment of the funding.

64. In conclusion, we consider that the issue of credits to shareholders does not constitute a reason for a downgrade and that the NBB is compliant with principle 6 from 1 January 2013 on (when the insurance participations will be deducted from tier 1 and tier 2).

\section{BCP 7: Risk management}

65. The NBB plans to review its internal governance framework, including risk management, starting in the autumn of 2013. At that moment, we will take into account the IMF's recommendations regarding the Board's oversight role for risk management and on how to integrate risk management and capital setting better.

\section{BCP 8: Credit risk}

66. We largely agree with the assessment but it is unclear whether BCP 8 requires the regulation to prohibit some credit to shareholders because conflicts of interest may arise (and have arisen in the past). The management of conflicts of interest between the bank and the shareholders is already regulated by the provisions of company law and the guidelines of the NBB on internal governance. On the basis of these guidelines, each institution must define a policy relating to conflicts of interest which shall be subject to the scrutiny of the NBB. We agree that these legal provisions and guidelines are not necessary sufficient but NBB has clarified the own funds regulation in order to be able to deduct some transactions made between the bank and its shareholders from the own funds (see above for BCP 6). 


\section{BCP 10: Large exposure limits}

67. The NBB will examine whether to use the national discretion to set a stricter limit on large exposures within smaller institutions when transposing Capital Requirements Directive, Fourth Iteration (CRD IV).

\section{BCP 12: Country and transfer risks}

68. We largely agree with the assessment but underline that the current guidelines of the NBB relating to credit risk management and concentration risk ensure already the compliance with the main principles applicable to the management of country risk (notably obligation to define a policy approved by the board, to set limits, to monitor the evolution of the exposures and the risks, to have an adequate provisioning policy and process). Adding specific guidance on country risk would be mainly a repetition of what is already included in the current guidelines on credit risk and concentration risk.

\section{BCP 16: Interest rate risk in the banking book}

69. Interest rate risk has been recognized as one of the priorities in the NBB's Risk Review 2013. As explained to the IMF, the NBB has set up since 2012 an extensive program to further develop its supervision regarding interest rate risk that runs throughout its different supervision departments. When rolling out this program, the NBB will consider how the recommendations in this field can be translated into the NBB's practice.

\section{BCP 17: Internal control and audit}

70. It is unclear whether the actual $B C P 17$ requires that the supervisor should be satisfied as to the effectiveness of the internal controls. The June 2012 BCBS document requires the internal audit function to provide independent assurance on the quality and effectiveness of a bank's internal control.

71. If the supervisor should be satisfied as to the effectiveness of the internal controls, several options could be examined:

- The Bank could require the internal audit function to adhere to the IIA's International Professional Practices Framework (Practice Advisory 2130-1) and to the recently published principles of the BCBS document about the internal audit function in banks;

- The Bank could require the external auditors to give positive assurance on the design and effectiveness of the internal controls. As for internal controls over financial reporting, a reference could be made to PCAOB standard AS 5 (there is no equivalent in the IAASB suite of standards), for the other internal controls reference could be made to ISAE 3000 . This standard is under revision and would require the Bank to describe in detail what is expected and what constitutes an acceptable internal control framework; 
- It could be envisaged that positive assurance is obtained through on-site inspections performed by the Bank. This could be dealt with in the context of the NOVA project (aiming at a harmonization of and consistency in methods across the supervisory departments). It should however not be expected that such a positive assurance will be obtained on a yearly basis for all supervised institutions and regarding their complete internal control system.

72. We consider that obtaining, in a systematic and sufficiently documented way, comfort as to the design and effectiveness of internal controls is indeed necessary. The report by the external auditor is only one of the building blocks for the control by the NBB and its importance should therefore not be overestimated.

73. To summarize, in our opinion, comfort should be obtained through a pre-defined combination of senior management's self-assessment (as approved by the Board), ICAAP reporting, input from the internal auditors (cf. recent BCBS document about the internal audit function in banks) and from the external auditor, as well as NBB on-site inspections to test these different inputs. This combination is currently the case. We agree however that the process for integrating these different building blocks and for steering the interaction between them could be made somewhat stricter. We will also enhance our own quality assurance on the input of the external auditor. The NBB will include this work when designing baseline supervision (see also BCP 20).

\section{BCP 20: Supervisory techniques}

74. We overall agree with the assessment but like to offer some additional inputs to the points contained in the detailed assessment:

- Supervisory action and planning is generally based on priorities and oriented to high risk institutions. We confirm the need to better document choices and to present supervisory planning and realized actions on the basis of a formally agreed and sector wide methodology;

- Pressure is put on team members to strengthen the internal documentation process, to systematically introduce standard presentation, including comparison to peers, in order to make risk assessment more comprehensive and ensure level playing field;

- The ongoing development of a enhanced scorecard system will strengthen the structured dialogue both with the institutions concerned and with their approved commissioners and the competent supervisory authorities, notably via the colleges of supervisors, will drive the decision making process, and will be systematically used and included in periodic reporting to the Board;

- This enhanced scorecarding will facilitate clustering on a more refined and risk-focused basis and will lead to a more balanced and risk based supervisory planning and subsequent appropriate assignment of staff. 
75. At the time of closing the FSAP mission, the NBB has already started work to implement a baseline supervision approach. We are in the process of identifying the different clusters and as result of this process, we have to define a baseline supervision even for the low risk institutions.

\section{BCP 21: Supervisory reporting}

76. The European Implementing Technical Standards (ITSs) on reporting, currently prepared by the EBA in the context of the future CRD IV, will shorten the remittance dates for prudential returns. These standards will become directly applicable in Belgium. 


\section{DETAILED ASSESSMENT}

77. Table $\mathbf{3}$ below offers the detailed Principle-by-Principle assessment. It provides a "description" of the system with regard to a particular Principle, a grading or "assessment," and a "comments."

Table 3. Detailed Assessment of Compliance with the Basel Core Principles

\begin{tabular}{|c|c|}
\hline Principle 1 & $\begin{array}{l}\text { Objectives, autonomy, powers, and resources. An effective system of banking } \\
\text { supervision will have clear responsibilities and objectives for each authority involved in the } \\
\text { supervision of banks. Each such authority should possess operational independence, } \\
\text { transparent processes, sound governance and adequate resources, and be accountable for } \\
\text { the discharge of its duties. A suitable legal framework for banking supervision is also } \\
\text { necessary, including provisions relating to authorization of banking establishments and } \\
\text { their ongoing supervision; powers to address compliance with laws as well as safety and } \\
\text { soundness concerns; and legal protection for supervisors. Arrangements for sharing } \\
\text { information between supervisors and protecting the confidentiality of such information } \\
\text { should be in place. }\end{array}$ \\
\hline Principle 1(1) & $\begin{array}{l}\text { Responsibilities and objectives. } \\
\text { An effective system of banking supervision will have clear responsibilities and objectives for } \\
\text { each authority involved in the supervision of banks. }\end{array}$ \\
\hline \multicolumn{2}{|l|}{ Essential criteria } \\
\hline EC1 & $\begin{array}{l}\text { Laws are in place for banking, and for the authority (each of the authorities) involved in } \\
\text { banking supervision. The responsibilities and objectives of each of the authorities are } \\
\text { clearly defined and publicly disclosed. }\end{array}$ \\
\hline \multirow[t]{4}{*}{$\begin{array}{l}\text { Description and } \\
\text { findings re EC1 }\end{array}$} & $\begin{array}{l}\text { The legal framework for banking supervision can be found in the Law of } 22 \text { March } 1993 \\
\text { (the "Banking Law") and the Law of } 22 \text { February } 1998 \text { (the "NBB Organic Law"). Under } \\
\text { Articles } 12 \text { bis, 36/2 and 36/3 of the NBB Organic Law, the NBB is responsible for banking } \\
\text { supervision and the Banking Law (Article 1) establishes the legal status and supervision of } \\
\text { credit institutions ("the Banking Law "). The Banking Law further establishes (Article 46) } \\
\text { that the NBB is responsible for ensuring that banks operate according to the Banking Law } \\
\text { and decrees and regulations implementing them. }\end{array}$ \\
\hline & $\begin{array}{l}\text { Although the legal framework provides clarity that banks shall be subject to supervision } \\
\text { and the NBB is the supervisory authority, neither the Banking Law nor the NBB Organic } \\
\text { Law clearly creates publicly stated objectives for NBB in respect of supervision (for } \\
\text { example a number of jurisdictions require that supervision is to be undertaken in order to } \\
\text { achieve or to support the safety and soundness of the supervised institutions). }\end{array}$ \\
\hline & $\begin{array}{l}\text { Belgian regulatory architecture was amended by the law of } 2 \text { July 2010, which introduced } \\
\text { the "twin peaks" model from April } 2011 \text {. Both the Organic Law and the Banking Law have } \\
\text { been amended so that the banking supervisory responsibility has transferred to the NBB, } \\
\text { succeeding the former Banking Finance and Insurance Commission (CBFA). }\end{array}$ \\
\hline & $\begin{array}{l}\text { Following the introduction of the Twin-Peaks model the NBB became responsible for the } \\
\text { micro- and macro-prudential supervision of banks, insurance and stockbroking } \\
\text { investment firms ("sociétés de bourse" - "beursvennootschappen"), and also clearing and } \\
\text { settlement institutions. Correspondingly, the FSMA is responsible for market supervision, } \\
\text { conduct of business and the supervision of certain institutions (UCITS management } \\
\text { companies, asset management companies and investment advisors). }\end{array}$ \\
\hline
\end{tabular}




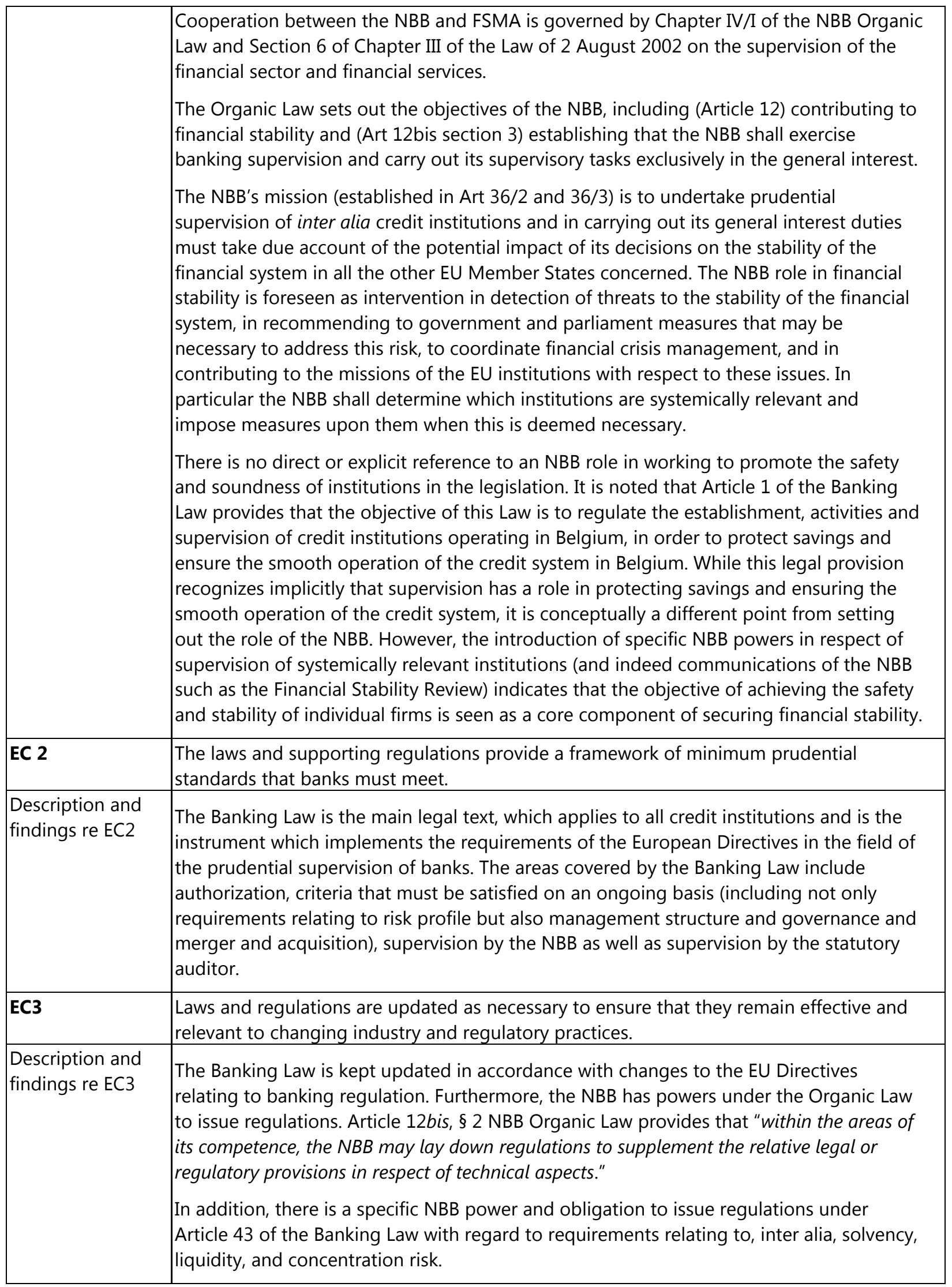




\begin{tabular}{|c|c|}
\hline & $\begin{array}{l}\text { Finally the NBB can and does issue Circulars to clarify its prudential expectations in } \\
\text { respect of some more broadly drafted requirements under the Banking Law where } \\
\text { standards are expected to increase over time (e.g., Circulars in relation to Article } 20 \text { and } \\
\text { Article 20bis). The Circulars do not have the force of regulations and the NBB cannot } \\
\text { impose a sanction solely on the basis of failure to comply with a Circular. However, given } \\
\text { that the Circular is an elaboration of the supervisor's intentions of the manner in which } \\
\text { the law will be applied, sanction could be applied in respect of breach of the underlying } \\
\text { law. }\end{array}$ \\
\hline EC4 & $\begin{array}{l}\text { The supervisor confirms that information on the financial strength and performance of the } \\
\text { industry under its jurisdiction is publicly available. }\end{array}$ \\
\hline $\begin{array}{l}\text { Description and } \\
\text { findings re EC4 }\end{array}$ & $\begin{array}{l}\text { The NBB publishes an annual Financial Stability Review, which provides information on } \\
\text { the strength and performance of the financial sector. The NBB is also legally required } \\
\text { (Article } 28 \text { of the Organic Law) to publish an annual report on its activities, which also } \\
\text { provides an overview of financial stability }\end{array}$ \\
\hline \multicolumn{2}{|l|}{$\begin{array}{l}\text { Additional } \\
\text { criteria }\end{array}$} \\
\hline AC1 & $\begin{array}{l}\text { In determining supervisory programmes and allocating resources, supervisors take into } \\
\text { account the risks posed by individual banks and banking groups and the different } \\
\text { approaches available to mitigate those risks. }\end{array}$ \\
\hline $\begin{array}{l}\text { Description and } \\
\text { findings re } A C 1\end{array}$ & $\begin{array}{l}\text { The NBB applies and is continuing to refine its approach to risk based supervision (please } \\
\text { see wider discussion under CPs } 19 \text { and 20), which incorporates an approach, which } \\
\text { allocates proportionally to identified risks. Recent changes to the legal framework } \\
\text { incorporate the concept of a systemically important institution and supervisory planning } \\
\text { takes these provisions into account. }\end{array}$ \\
\hline $\begin{array}{l}\text { Assessment of } \\
\text { Principle 1(1) } \\
\end{array}$ & Compliant \\
\hline \multirow[t]{3}{*}{ Comments } & $\begin{array}{l}\text { The laws create an overarching legal framework which is applied to banks and which is } \\
\text { amended in a timely manner to take account of national and EU developments. } \\
\text { The principle requires there to be clear objectives and responsibilities for each authority } \\
\text { for involved in the supervision of banks. As a result of allocating supervisory } \\
\text { responsibility to the central bank, the authorities had to amend the Organic Law of the } \\
\text { NBB to reflect its new roles. It is a challenging process to amend regulatory architecture } \\
\text { to incorporate a significant function such as prudential supervision within an established } \\
\text { body that had a pre-existing and very clear mandate such as a central bank. }\end{array}$ \\
\hline & $\begin{array}{l}\text { The NBB Organic Law establishes that the NBB will be responsible for supervising credit } \\
\text { institutions and also that it has a responsibility to detect threats to financial stability. The } \\
\text { legal mandate is thus in place, but the legal mandate does not express the purpose of } \\
\text { prudential supervision (e.g. a responsibility for the safety and soundness of individual } \\
\text { institutions) and it is not stated how the NBB must balance the priorities and demands of } \\
\text { prudential supervision with those of protecting financial stability (e.g., that the safety and } \\
\text { soundness of individual institutions is critical to but not necessarily sufficient to achieve a } \\
\text { broader goal of financial stability). }\end{array}$ \\
\hline & From the perspective of public policy, the legal mandate therefore lacks full clarity and it \\
\hline
\end{tabular}




\begin{tabular}{|c|c|}
\hline & $\begin{array}{l}\text { may not be transparent to the public how the central bank is expected to fulfill its roles. } \\
\text { Therefore it would be helpful if the relationship between the two functions could be } \\
\text { clearly articulated. } \\
\text { It is not essential to amend the NBB Organic Law to address this concern, but it would be } \\
\text { opportune to make amendments during the redrafting of the Law that is intended during } \\
\text { 2013.The NBB may, in any case, wish to consider articulating a focused mission statement } \\
\text { and objective, which they could promulgate on their website in the manner adopted by } \\
\text { some other central bank supervisory authorities. }\end{array}$ \\
\hline Principle 1(2). & $\begin{array}{l}\text { Independence, accountability and transparency. Each such authority should possess } \\
\text { operational independence, transparent processes, sound governance and adequate } \\
\text { resources, and be accountable for the discharge of its duties. }\end{array}$ \\
\hline \multicolumn{2}{|r|}{ e } \\
\hline EC1 & $\begin{array}{l}\text { The operational independence, accountability and governance structures of each } \\
\text { supervisory authority are prescribed by law and publicly disclosed. There is, in practice, no } \\
\text { evidence of government or industry interference which compromises the operational } \\
\text { independence of each authority, or in each authority's ability to obtain and deploy the } \\
\text { resources needed to carry out its mandate. The head(s) of the supervisory authority can be } \\
\text { removed from office during his (their) term only for reasons specified in law. The reason(s) } \\
\text { for removal should be publicly disclosed. }\end{array}$ \\
\hline \multirow[t]{6}{*}{$\begin{array}{l}\text { Description and } \\
\text { findings re EC1 }\end{array}$} & $\begin{array}{l}\text { As noted under CP 1(1), EC1, the supervisory architecture of Belgium was established with } \\
\text { the Law of } 2 \text { July } 2010 \text { (the "Twin Peaks Law"). The Royal Decree of } 3 \text { March } 2011 \\
\text { implemented the law, thus establishing the Twin Peaks model from } 1 \text { April } 2011 \text {. Under } \\
\text { the Twin Peaks model, the NBB is responsible for both the micro- and macro-prudential } \\
\text { supervision of-inter alia-credit institutions. }\end{array}$ \\
\hline & $\begin{array}{l}\text { The Organic Law (Chapter III) sets out the governance and organization of the NBB. There } \\
\text { are five decision-making bodies within the NBB: the Governor, the Board of Directors, the } \\
\text { Council of Regency, the Board of Censors and the Sanctions Committee. }\end{array}$ \\
\hline & $\begin{array}{l}\text { The Governor directs the NBB and presides over the Board of Directors and the Council } \\
\text { of Regency. He is appointed by the King for a renewable term of five years, with no limit } \\
\text { to the number of times that his mandate can be renewed. There is however, an age limit } \\
\text { of } 67 \text {. }\end{array}$ \\
\hline & $\begin{array}{l}\text { The Governor can only be dismissed during his term for reasons specified by Article } 23 \text { of } \\
\text { the Organic Law (i.e., due to serious misconduct or if he or she no longer fulfils the } \\
\text { conditions required for the performance of his or her duties). It is not mandatory for the } \\
\text { reasons for dismissal to be publicly disclosed. }\end{array}$ \\
\hline & $\begin{array}{l}\text { In addition, it should be noted that under Belgian administrative rules, a motivation must } \\
\text { be provided for all administrative acts. This means that the decision of dismissal must } \\
\text { clearly identify the factual and legal elements on which it is based. Hence there is } \\
\text { transparency of the decision vis-à-vis the person it concerns (i.e., the Governor). }\end{array}$ \\
\hline & $\begin{array}{l}\text { Furthermore, Article } 23 \text { grants the Governor the right to challenge a decision of dismissal } \\
\text { in accordance with Article } 14.2 \text { of the statutes of the Euro System of Central Banks. Hence } \\
\text { the decision may be referred to the Court of Justice on grounds of infringement of the } \\
\text { Treaties or of any rule of law relating to their application. In such a case, the judgment } \\
\text { shall be delivered in open court and the judgment is published in the Official Journal. } \\
\text { Hence, in the event that the Governor has challenged a decision to dismiss it is possible } \\
\text { that the reasons for the dismissal may become public. }\end{array}$ \\
\hline
\end{tabular}


Such arrangements provide for greater legal certainty for the position of the Governor and of the independence of the NBB as an institution without however meeting the requirements of the criterion, which states that the reasons for dismissal should be public, not merely known to the individual dismissed, or have the potential to become public in the context of a legal challenge. While the grounds for dismissal are limited the public cannot know whether the incumbent is being dismissed for misconduct or failure to fulfill the conditions for performance of duty (such as grave ill health). This means that transparency intended by this principle is limited.

The Board of Directors is responsible for the administration and management of the NBB and decides on the direction of its policy. Besides the Governor, the Board of Directors consists of at least five and at most seven Directors, appointed by the King upon the recommendation of the Council of Regency. Currently, the Board comprises eight members; in addition there are two special representatives (who are not member of the Board) advising on prudential supervision. This method of nominating the Directors was introduced by law in 1948 to emphasize the public interest character of the NBB's activities. In the preparations for the Law of 28 July 1948 the legislature expressed its desire that the method of appointing the Directors and also the Regents should ensure both the NBB's total independence from individual interests and the technical competence of the candidates.

The Directors are appointed for six years and can only be dismissed for the reasons cited in Article 23 NBB Organic Law. The Governor excepted, the Board is divided equally between Dutch and French speaking members. Currently the Board of Directors consists of seven Directors and the Governor, which totals eight members. In order to avoid any conflict of interests, the Directors may not, under the terms of the Organic Law, except in a limited number of specified instances, perform duties in commercial companies or companies, which are commercial in form, or in public institutions engaged in industrial, commercial or financial activities. They are also prohibited from taking on certain political posts (as members of a parliament, government or ministerial cabinet). Conflict of interest is further managed by the fact that if a member of the Board of Directors has, directly or indirectly, an interest relating to proprietary rights, which conflicts with a decision or transaction of the Board, he must inform the Board and also the auditor and recuse himself from the discussion and decision making, a fact, which must be formally minuted.

The Council of Regency discusses monetary policy, the economic state of Belgium and the EU, the supervisory policy applicable to the sectors under NBB supervision, developments with regard to supervision and other issues of general interest to the NBB. The Council approves the budget, the annual accounts and the Annual Report of the NBB as well determining the rules of procedure of the NBB ("huishoudelijk reglement" /

"règlement d'ordre intérieur"). The Council also determines the wages and pensions of the members of the Board of Directors.

The Council is composed of the Governor, the Directors and ten Regents, with an equal number of French and Dutch speaking regents. The regents are elected by the general meeting for a renewable term of three years. Of the ten regents, five are chosen from names submitted by the Minister of Finance and the remainder from names submitted by the most representative labour organizations, industry and commerce, agriculture and from small and medium-sized enterprises and merchants. Regents may not be members of the administrative, management or supervisory bodies of an institution subject to the supervision of the NBB, nor may they perform management duties in such an institution. The procedure for proposing and appointing the Regents was designed to ensure that 
the various Belgian socioeconomic interests were fairly represented.

Conflict of interest is managed through the Organic Law prohibition on the Regents being members of the administrative, management or supervisory bodies of an institution subject to the supervision of the NBB (Articles 8 , or 12 bis), nor may they perform management duties in such an institution or take on certain political posts (as members of a parliament, government or ministerial cabinet).

The Board of Censors is responsible for supervising the preparation and implementation of the budget and constitutes the audit committee of the NBB and exercises the tasks laid down by Article 21 bis of the Organic Law. Decisions are taken by a majority vote and it meets eight times a year. The Board of Censors reports to the Board of Directors and to the Council of Regency and can make comments and recommendations with regard to the issues that fall within its competence. The Board is composed of ten members including an equal number of French and Dutch speakers. The censors are elected by the general meeting of shareholders of the NBB for a renewable term of three years.

The Sanctions Committee pronounces on the imposition by the NBB of administrative fines ("geldboete"/"amende") and penalties ("dwangsom"/"astreinte").

There are six members of the Sanctions Committee, of which two members plus the chairman are required for a valid decision to be reached. The members are appointed by the King: 1) a State counselor or honorary State counselor, proposed by the First President of the Council of State; 2) a counselor or honorary counselor of the Court of Cassation, proposed by the First President of the Court of Cassation; 3) two magistrates who are neither members of the Court of Cassation, nor of the Brussels Court of Appeal; and 4) two other members. Conflict of interest rules are enshrined in the Organic Law so members may not consider a case in which they have a personal interest. For the three years preceding their appointment, the members of the Sanctions Committee may not have been employed by the NBB either in Board capacity or on the staff. Members of the Sanctions Committee have a term of six years, which is renewable. Members may be dismissed by the King (i.e., the federal government) only if they no longer fulfill the conditions for the performance of their duties or if they have been guilty of serious misconduct. At present the Sanctions Committee does not exist as no appointments have been confirmed by Royal Decree.

Restrictions on eligibility of service: There is an age limit of sixty-seven for the members of the Board of Directors, Council of Regency and the Board of Censors, although there are provisions to allow the completion of a term of service, which in the case of the Governor needs to be granted by Royal Decree. In no case may an office-holder remain in position beyond the age of seventy.

\section{NBB's Legal status and oversight}

The NBB is an "société anonyme de droit public / naamloze vennootschap van publiek recht," i.e., a public institution, which has adopted the form of a public limited liability company. It was created for the purpose of carrying out tasks of "public service."

The NBB has operational and financial autonomy with respect to its supervisory function. The decisions of the NBB in its capacity as administrative authority are subject to a right of appeal at the Council of State, but the scrutiny applies only to the legal process, i.e., assessing the legality of the decision, but not the substance of the decision. In exercising its supervisory responsibilities, the NBB possesses a measure of "discretionary power" but must explain the grounds (the factual basis and legal grounds) behind its decisions and is also subject to principles of consistency and proportionality in its decision making. The 


\begin{tabular}{|c|c|}
\hline & $\begin{array}{l}\text { NBB's decisions to impose administrative fines or penalties, are subject to appeal lodged } \\
\text { only with the Brussels Court of Appeal. } \\
\text { Regulations issued by the NBB require enforcement via Royal Decree ("tutelle } \\
\text { d'approbation" / "goedkeuringsvoogdij"). The NBB attaches great importance to } \\
\text { consultation with firms and their professional associations when preparing regulations } \\
\text { and Circulars. } \\
\text { NBB has financial independence: its expenses for prudential supervision are met by fees } \\
\text { paid by financial institutions. The extent of its authorized expenditures and the manner in } \\
\text { which these expenditures are covered, are laid down in detail in the Royal Decree of } 17 \\
\text { July } 2012 \text {. }\end{array}$ \\
\hline EC2 & $\begin{array}{l}\text { The supervisor publishes objectives and is accountable through a transparent framework } \\
\text { for the discharge of its duties in relation to those objectives. }\end{array}$ \\
\hline $\begin{array}{l}\text { Description and } \\
\text { findings re EC2 }\end{array}$ & $\begin{array}{l}\text { The website of the NBB, its annual report and its annual Financial Stability Review are the } \\
\text { means by which the NBB communicates its results, actions and clearly states the missions } \\
\text { and activities of the NBB as an organization, including the task of prudential supervision. }\end{array}$ \\
\hline EC3 & $\begin{array}{l}\text { The supervisory authority and its staff have credibility based on their professionalism and } \\
\text { integrity. }\end{array}$ \\
\hline $\begin{array}{l}\text { Description and } \\
\text { findings re } E C 3\end{array}$ & $\begin{array}{l}\text { The prudential staff of the NBB are a mix of staff brought from the former CBFA and staff } \\
\text { of the NBB itself. Staff must abide by the code of ethics laid down by the Council of } \\
\text { Regency (in accordance with Article 26, section } 3 \text { of the NBB Organic Law). This code of } \\
\text { ethics includes various obligations aimed at ensuring the integrity of the NBB including, } \\
\text { in particular, a prohibition on trading financial instruments of companies under NBB's } \\
\text { supervision. } \\
\text { Discussions with the industry and professional bodies within Belgium gave a consistent } \\
\text { message that the NBB is seen as accessible, professional and demonstrating technical } \\
\text { expertise, which commands the respect of supervised institutions. } \\
\text { See also EC1 for conflict of interest restrictions for individuals on the Board of Directors and } \\
\text { Council of Regency. }\end{array}$ \\
\hline EC4 & $\begin{array}{l}\text { The supervisor is financed in a manner that does not undermine its autonomy or } \\
\text { independence and permits it to conduct effective supervision and oversight. This includes: } \\
\text { A budget that provides for staff in sufficient numbers and with skills } \\
\text { commensurate with the size and complexity of the institutions supervised. } \\
\text { Salary scales that allow it to attract and retain qualified staff } \\
\text { - The ability to commission outside experts with the necessary professional skills } \\
\text { and independence and subject to necessary confidentiality restrictions to conduct } \\
\text { supervisory tasks } \\
\text { A training budget and programme that provides regular training opportunities for } \\
\text { staff } \\
\text { A budget for computers and other equipment sufficient to equip its staff with the } \\
\text { tools needed to review the banking industry and assess individual banks and } \\
\text { banking groups; and } \\
\text { A travel budget that allows appropriate on-site work. }\end{array}$ \\
\hline $\begin{array}{l}\text { Description and } \\
\text { findings re EC4 }\end{array}$ & The NBB funds its prudential activities through fees levied on the financial institutions \\
\hline
\end{tabular}


that it supervises (Article 12bis, section 4 NBB Organic Law). This principle of primary legislation is further elaborated by the Royal Decree of 17 July 2012 on covering the operating expenses of the NBB in connection with the supervision on financial institutions. Although the NBB budget is subject to parliamentary scrutiny, because the prudential function is independently funded there has been no experience of, and there is no expectation of, pressure being placed on this budget.

The Royal Decree of 17 July 2012 establishes specifically that:

- the fees should cover the effective cost of supervision;

- there should be stability and predictability in the financing burden imposed on supervised institutions;

- the system is pre-financed with subsequent amendments possible at the year- end (either repayment or additional levies as necessary).

The Royal Decree of 17 July 2012 sets a global amount of resources, which increases each year as follows:

a) for personnel costs, the increase of resources is linked to increases applied to the NBB staff.

b) All other expenses are adjusted in line with consumer prices.

Additional amounts added to the levy take account of the real costs driven by coordination and cooperation with other supervisory authorities.

The two sectors the NBB supervises are both levied - the insurance sector on the one hand and the banking and securities sector (investment firms and clearing and settlement institutions) on the other. Each sector is subject to two types of levy. All firms in the sector are subject to a main levy but SIFIs are required to pay a supplementary amount.

There is no ceiling placed on the numbers of staff When taking over the micro-prudential supervision from CBFA in April 2011, the staff dedicated to prudential regulation and supervision numbered around 200 full time employees (FTE). The NBB Board decided to increase the resources by 40 FTE to benefit both banking and insurance sectors.

In September 2012, the staff dedicated to prudential regulation and supervision amounted to around 230 FTE. This includes staff dedicated to prudential regulation, financial stability, supervision of banking and insurance sector as well as market infrastructure, specific operational support and prudential law. Other support functions, such as secretariat to the Board, IT support, are available to the prudential departments but are not included in these figures.

At least 70 percent of the NBB staff dedicated to prudential regulation and supervision are professional executives. Recent studies (e.g., Hudson Banking Salary Survey) show that the compensation offered at NBB is in the top quartile for commensurate roles.

The NBB have identified a general need for IT personnel. Though supervision does not have dedicated IT or HR, it has enjoyed a major IT budget to deliver a global programe to renew the entire IT architecture and which has absorbed up to 50 percent of the IT staff. 


\begin{tabular}{|c|c|}
\hline \multicolumn{2}{|l|}{$\begin{array}{l}\text { Additional } \\
\text { criteria }\end{array}$} \\
\hline AC1 & The head(s) of the supervisory authority is (are) appointed for a minimum term. \\
\hline $\begin{array}{l}\text { Description and } \\
\text { findings re } A C 1\end{array}$ & The Governor of the NBB is appointed for a minimum, renewable term of five years. \\
\hline $\begin{array}{l}\text { Assessment of } \\
\text { Principle 1(2) }\end{array}$ & Largely Compliant \\
\hline \multirow[t]{5}{*}{ Comments } & $\begin{array}{l}\text { Although the supervisory function - which is a department within the central bank - is } \\
\text { not protected by laws ensuring the independence of the functions of the Euro System of } \\
\text { Central Banks, of which the NBB is a member, there are clear lines of accountability, } \\
\text { transparency, separate funding and there is no indication in practice that there is any } \\
\text { interference with the operational independence of the NBB acting in its supervisory } \\
\text { capacity. }\end{array}$ \\
\hline & $\begin{array}{l}\text { Lack of full compliance with this CP derives from the fact it is a requirement of CP1(2) } \\
\text { that the reasons for the removal of the head of the supervisory body must be publicly } \\
\text { disclosed. This is not the case for the NBB. The assessors accept that there are limited } \\
\text { grounds for dismissal and that the motivation for the dismissal must be made known to } \\
\text { the incumbent (i.e., the Governor) and that the incumbent has a right of legal challenge, } \\
\text { which may ultimately result in a judgement that will be made public and which may } \\
\text { disclose the reasons for the dismissal (as discussed under EC1). Nonetheless, and while } \\
\text { accepting that these arrangements support the independence of the NBB, the } \\
\text { arrangements do not meet the criterion set out and the level of transparency falls short } \\
\text { of what is required. }\end{array}$ \\
\hline & $\begin{array}{l}\text { Additionally, it was unclear to the assessors at the time of the mission that the } \\
\text { supervisory functions had adequate resources to deliver the objective of systematic risk } \\
\text { based supervision for all institutions. In mitigation it is acknowleged that there are many } \\
\text { complex factors to be taken into account not least including the need for increase in staff } \\
\text { to be undertaken at a pace at which they can be effectively absorbed into the } \\
\text { organization. It is welcome that the NBB has increased resources in comparison with the } \\
\text { former headcount, and also that there is now no formal ceiling on a headcount. In terms } \\
\text { of resources, the NBB is well placed to fund its needs (through industry levy). The } \\
\text { challenge lies in identifying the scale of future resource needs in the face of current } \\
\text { structural uncertainties (in particular discussions around supervision within the Single } \\
\text { Supervisory Mechanism) and also ensuring that as increases are identified that they can } \\
\text { be appropriately managed and integrated into the supervisory function. Nonetheless, the } \\
\text { NBB is strongly encouraged to continue to seek to reassess the numbers and skill set } \\
\text { needed to deliver their enhanced risk based supervisory processes in a systematic } \\
\text { manner for all their institutions. }\end{array}$ \\
\hline & $\begin{array}{l}\text { It is also noted that while the NBB enjoys some limited rule making powers (as required } \\
\text { under CP1(3)) the rulemaking requires the issuance of a Royal Decree to take legal effect. } \\
\text { As part of the process of obtaining the Royal Decree, the proposed regulation must be } \\
\text { open to ministerial scrutiny and possible veto. In practical terms this has had and is likely } \\
\text { to have limited or nil effect on the independence of the NBB in this capacity, but it would } \\
\text { be preferable for the NBB to have powers to issue binding reglations without this formal } \\
\text { constraint. It is, however, recognised that continued regulatory changes within the EU } \\
\text { (such as the "single rule book") may render this particular point redundant. }\end{array}$ \\
\hline & $\begin{array}{l}\text { Separately, the assessors noted that under the NBB Organic Law (and as reflected in the } \\
\text { Statutes and Corporate Governance Charter) that the Minister of Finance has the right to }\end{array}$ \\
\hline
\end{tabular}




\begin{tabular}{|c|c|}
\hline & $\begin{array}{l}\text { suspend decisions of the NBB. Unlike the functions of the NBB in respect of its duties as } \\
\text { part of the Eurosystem of Central Banks (ESCB), there was no legal carve out clarifying } \\
\text { that the Minister had no vires in respect of prudential supervision. In discussion with the } \\
\text { NBB staff it was understood that the Minister has not exercised this power in practice. } \\
\text { Moreover, it appeared that the intention had been to ensure that prudential supervision } \\
\text { enjoyed the same carve-out as the ESCB and this loophole would be addressed in a re- } \\
\text { writing of the NBB Organic Law planned for 2013. For purposes of good governance and } \\
\text { complete clarity it is recommended that the authorities take this opportunity as they } \\
\text { already plan to do. }\end{array}$ \\
\hline Principle 1(3) & $\begin{array}{l}\text { Legal framework. A suitable legal framework for banking supervision is also necessary, } \\
\text { including provisions relating to authorization of banking establishments and their ongoing } \\
\text { supervision. }\end{array}$ \\
\hline \multicolumn{2}{|l|}{ Essential criteria } \\
\hline $\mathrm{EC1}$ & $\begin{array}{l}\text { The law identifies the authority (or authorities) responsible for granting and withdrawing } \\
\text { banking licenses. }\end{array}$ \\
\hline $\begin{array}{l}\text { Description and } \\
\text { findings re EC1 }\end{array}$ & $\begin{array}{l}\text { The Banking Law (Section I, Article 7) lays down the exclusive competence of the NBB to } \\
\text { authorize a bank and also (Article 57) that the NBB is exclusively authorized to revoke such } \\
\text { authorization. }\end{array}$ \\
\hline EC2 & $\begin{array}{l}\text { The law empowers the supervisor to set prudential rules (without changing laws). The } \\
\text { supervisor consults publicly and in a timely way on proposed changes, as appropriate. }\end{array}$ \\
\hline $\begin{array}{l}\text { Description and } \\
\text { findings re } E C 2\end{array}$ & $\begin{array}{l}\text { In Belgium, in common with all EU member states, many prudential standards are } \\
\text { prescribed in EU legislation and transposed into Belgian law. While the NBB cannot } \\
\text { change laws, it may issue prudential regulations under the Organic Law Article } 12 b i s \text {, } \\
\text { section } 2 \text { NBB), which provides that "within the areas of its competence, the NBB may lay } \\
\text { down regulations to supplement the relative legal or regulatory provisions in respect of } \\
\text { technical aspects." Such regulation only takes legal effect following enforcement by Royal } \\
\text { Decree. The NBB has the option of open consultation on any proposed regulation. } \\
\text { In addition, there is a specific NBB competence for issuing regulations under Article } 43 \text { of } \\
\text { the Banking Law, which requires the NBB to issue regulations with regard to } \\
\text { requirements relating to, inter alia, solvency, liquidity and concentration risk (e.g., the } \\
\text { NBB Own Fund Regulation and the Liquidity Regulation). (See also CP1(1) EC3). } \\
\text { Finally, the Banking Law (Articles 20, section } 4 \text { and 20bis, section 8) states that the NBB } \\
\text { can set out prudential rules with regard to specific topics such as risk management. The } \\
\text { NBB has exercised this power. }\end{array}$ \\
\hline EC3 & $\begin{array}{l}\text { The law or regulations empower the supervisor to obtain information from the banks and } \\
\text { banking groups in the form and frequency it deems necessary. }\end{array}$ \\
\hline $\begin{array}{l}\text { Description and } \\
\text { findings re EC3 }\end{array}$ & $\begin{array}{l}\text { The NBB Organic Law (Article 36/19) provides that the NBB can obtain all necessary } \\
\text { information from the institutions under its supervision. } \\
\text { The Banking Law (Article 44) requires credit institutions to submit financial reports to the } \\
\text { NBB in the manner and frequency prescribed by the NBB. } \\
\text { Furthermore, Article } 46 \text { provides that the NBB may request information on the financial } \\
\text { position, transactions, the organization and operation of credit institutions. The parent of } \\
\text { the consolidated group must submit its financial statement to the NBB according to the } \\
\text { form and frequency specified by the NBB. }\end{array}$ \\
\hline
\end{tabular}




\begin{tabular}{|c|c|}
\hline & $\begin{array}{l}\text { Article } 49 \text { provides that the NBB can obtain necessary information from entities, which } \\
\text { control a credit institution, or which may be non-consolidated subsidiaries of a credit } \\
\text { institution provided that such entities are not already part of the consolidation or the } \\
\text { financial group (conglomerate), which is subject to supplementary supervision. } \\
\text { These articles grant the NBB the right to conduct on-site verification of information it has } \\
\text { received, or to require verification by accredited auditors or foreign experts. } \\
\text { It is a criminal offence under the Banking Law (Article 104, section 1, point 12) to refuse } \\
\text { to give the required information, or wrongful or incomplete information or to prevent the } \\
\text { NBB from carrying out inspection and verification procedures. (See Core Principle 1(4) } \\
\text { below). }\end{array}$ \\
\hline $\begin{array}{l}\text { Assessment of } \\
\text { Principle 1(3) }\end{array}$ & Compliant \\
\hline Comments & $\begin{array}{l}\text { The NBB operates within a legal framework that provides for authorization and ongoing } \\
\text { standards of supervision. }\end{array}$ \\
\hline Principle 1(4) & $\begin{array}{l}\text { Legal powers. A suitable legal framework for banking supervision is also necessary, } \\
\text { including powers to address compliance with laws as well as safety and soundness } \\
\text { concerns. }\end{array}$ \\
\hline Essential criteria & \\
\hline EC1 & $\begin{array}{l}\text { The law and regulations enable the supervisor to address compliance with laws and the } \\
\text { safety and soundness of the banks under its supervision. The law and regulations permit } \\
\text { the supervisor to apply qualitative judgement in safeguarding the safety and soundness of } \\
\text { the banks within its jurisdiction. }\end{array}$ \\
\hline $\begin{array}{l}\text { Description and } \\
\text { findings re EC1 }\end{array}$ & $\begin{array}{l}\text { Under Article } 46 \text { of the Banking Law the NBB is required to ensure that every credit } \\
\text { institution operates in conformity with the Banking Law and its implementing decrees } \\
\text { and regulations. } \\
\text { The law demands that the NBB pay specific attention to qualitative aspects of credit } \\
\text { institutions such as suitability of its risk management, its administrative and accounting } \\
\text { organization and internal control systems; in addition to the quantitative elements such } \\
\text { as the adequacy of its capital. }\end{array}$ \\
\hline EC2 & $\begin{array}{l}\text { The supervisor has full access to banks' board, management, staff and records in order to } \\
\text { review compliance with internal rules and limits as well as external laws and regulations. }\end{array}$ \\
\hline $\begin{array}{l}\text { Description and } \\
\text { findings re EC2 }\end{array}$ & $\begin{array}{l}\text { The NBB has the right to meet the board of a credit institution, its executive management, } \\
\text { its staff and have right to all records. Notably, the Banking Law (Article 46) gives NBB broad } \\
\text { powers to carry out on-site inspections on the firm's premises and read and copy } \\
\text { information in relation to compliance with banking regulations, the accuracy of information } \\
\text { provided by the institution as well as in relation to the adequacy of management, } \\
\text { administration, internal controls, governance and accounting of the institution. }\end{array}$ \\
\hline EC3 & $\begin{array}{l}\text { When, in a supervisor's judgment, a bank is not complying with laws or regulations or it is } \\
\text { or is likely to be engaged in unsafe and unsound practices, the supervisor has the power to: } \\
\text { - take (and/or require a bank to take) prompt remedial action; and } \\
\text { - Impose a range of sanctions (including the revocation of the banking license). }\end{array}$ \\
\hline
\end{tabular}


Description and findings re EC3
The Banking Law (Article 57) grants the NBB a range of remedial measures that it may apply. These measures extend from the appointment of a special commissioner, requirements with regard to solvency, liquidity, risk concentration, to the revocation of the banking license. (See also CP23).

Remedial measures should be distinguished from the administrative sanctions as described in Articles 102 and 103 of the Banking Law and the criminal sanctions as referred to in Articles 104 et seq. of the Banking Law

\section{Remedial measures}

In the event that the NBB uncovers deficiencies or lack of compliance with the laws and regulations it shall determine the timeframe within which the credit institution must rectify the situation (Article 57 Banking Law). Should the deadline not be met, the NBB may impose a number of measures:

- it may appoint a special commissioner, whose approval is required for all or part of the acts and decisions of the credit institution;

- it may impose additional requirements with regard to solvency, liquidity, and risk concentration;

- it may impose restrictions on the variable elements of remuneration;

- it may suspend for a certain period all or part of the credit institution's activities and can require an institution to transfer the shares it holds in accordance with Articles 32, §§ 4 and 5 Banking Law;

- it may order the institution's directors to be replaced or, failing compliance with the order, appoint one or more temporary directors; and finally,

- it may revoke the credit institution's authorization.

It must also be noted that in applying measures under Article 57, the NBB must act according to the principle of proportionality. This means that the measures imposed cannot exceed what it is necessary to remedy the credit institution's situation.

In the case of systemic institutions (where there could be an impact on the stability of the Belgian or international financial system) disposal of the assets or liabilities of the credit institution can be required under Article 57bis through the application of a Royal Decree. The NBB may initiate procedures for such a process, though this competence is shared with the government, which (in such an instance) is obliged to consult with the NBB. To date the powers under Article 57bis have not yet been exercised, although the NBB has reached the stage of initiating the process of disposal.

\section{Administrative sanctions}

The Banking Law provides for two types of administrative sanctions, namely fines and also publication of failure to comply with orders made to adhere to the provisions of the law (or implementing decrees).

Fines are imposed under Article 103, which allows the NBB to require compliance with the laws and regulations and to set a timetable for compliance. The infringement of the laws and regulations themselves can lead to a fine and the failure to comply with an order to rectify non-compliance within the specified timetable leads to a fine.

Thus, if the institution fails to comply with the requirements in the specified period the NBB may impose a fine of up to EUR 2,500,000 per infringement or a maximum of EUR 50,000 euros per each day's delay. 
In addition, the NBB has the right to impose an administrative fine for the infringement of the regulations (i.e., the same offence or same totality of offences for which a deadline for remedial action was set), which shall be between $€ 2,500$ and 2,500,000.

The fine is payable to the Ministry of Finance.

Publication of failure to comply with injunctions ordering it to comply with the provisions of this Law or its implementing decrees is governed by Article 102. In the event that publication might inflict significant damage upon the institution, the notice can be published without names being disclosed.

It should be noted that administrative sanctions would have to be decided upon by the Sanctions Committee and that at present a Sanctions Committee has not yet been convened at the NBB. Appointments to the Sanctions Committee must be ratified by the government and at the time of the mission names had not been confirmed.

\section{Criminal sanctions}

Article 104 Banking Law imposes a range of criminal sanctions for specific breaches of the Banking Law This is outside of the range of the NBB, which may not to impose these sanctions as this is the prerogative of the criminal courts.

Any criminal investigation, or action following such investigation, with regard to the potential breach of the Banking Law and other related regulations by administrators, directors, managers, statutory auditors of financial institutions should be notified to the NBB under the terms of the Banking Law

\section{Potential amendments}

At the time of the mission, the authorities were discussing potential legal changes that would allow for a more administratively efficient approach to imposing periodic penalty payments upon firms as one dimension of corrective and remedial measures. When the legal framework relating to the power of imposing administrative sanctions was imported into the Organic law of the NBB by the Twin Peaks Royal Decree it was provided that the Sanctions Committee was competent to impose fines ("geldboete"/"amende") and periodic penalty payments ("dwangsom"/"astreinte") to the supervised institutions. These two measures are seen as fundamentally different. Periodic penalty payments ("dwangsom"/ "astreinte") are intended to create an incentive to respect a requirement, while the purpose of fines is to punish an illicit behavior on ex post basis4. In the legal framework governing the FSMA (the Law of August 2nd 2002 as modified by the Law of 2 July 2010), however, the imposition of fines was in the competence of the Sanctions Committee and the imposition of periodic penalty payments was the sole competence of the Board of directors. The NBB would like to mirror this is division of responsibility and it is now intended to adopt a new law removing the qualification of "administrative sanction" from the periodic penalty payments ("dwangsom"/ "astreinte"). This would thus allow the adoption of such measures by the Board of Directors without the more elaborate and extensive procedures required at present (Articles 36/9 and seq. of the Organic Law of the NBB).

\footnotetext{
${ }^{4}$ Preparatory Documents, Parliament (Chambre des Représentants), 2001-2002, n50-1842/1, p. 288.
} 


\begin{tabular}{|c|c|}
\hline $\begin{array}{l}\text { Assessment of } \\
\text { Principle 1(4) }\end{array}$ & Compliant \\
\hline Comments & $\begin{array}{l}\text { The NBB enjoys a range of remedial measures that allow for an appropriate degree of } \\
\text { proportionality in its approach to breaches of laws and regulations. It is noted that the } \\
\text { drafting of Article } 57 \text { of the Banking Law usefully takes into consideration that there may } \\
\text { be a necessity for swift action in urgent situations. }\end{array}$ \\
\hline Principle 1(5) & $\begin{array}{l}\text { Legal protection. A suitable legal framework for banking supervision is also necessary, } \\
\text { including legal protection for supervisors. }\end{array}$ \\
\hline \multicolumn{2}{|r|}{ the } \\
\hline EC1 & $\begin{array}{l}\text { The law provides protection to the supervisory authority and its staff against lawsuits for } \\
\text { actions taken and/or omissions made while discharging their duties in good faith. }\end{array}$ \\
\hline $\begin{array}{l}\text { Description and } \\
\text { findings re EC1 }\end{array}$ & $\begin{array}{l}\text { Liability protection for the NBB and its staff is provided under the Organic Law (Article } \\
12 \text { bis, section 3): "the NBB, the members of its bodies and the members of its staff shall } \\
\text { not bear civil liability for their decisions, acts and conduct in the exercise of the legal } \\
\text { tasks of the NBB, save in the event of fraud or gross negligence." } \\
\text { Additionally, civil liability is limited to fraud or gross negligence in cases where persons } \\
\text { have carried out the remedial measures outlined in Article 57bis of the Banking Law (see } \\
\text { CP1(4) EC 3). }\end{array}$ \\
\hline EC2 & $\begin{array}{l}\text { The supervisory authority and its staff are adequately protected against the costs of } \\
\text { defending their actions and/or omissions made while discharging their duties in good faith. }\end{array}$ \\
\hline $\begin{array}{l}\text { Description and } \\
\text { findings re EC2 }\end{array}$ & $\begin{array}{l}\text { In } 2008 \text { an insurance agreement covering the costs of defending actions was concluded for } \\
\text { the NBB staff. This insurance agreement was amended in } 2011 \text { to also cover the NBB staff } \\
\text { working in relation to its prudential supervision tasks. }\end{array}$ \\
\hline $\begin{array}{l}\text { Assessment of } \\
\text { Principle 1(5) }\end{array}$ & Compliant \\
\hline Comments & $\begin{array}{l}\text { Appropriate legal protections have been put in place in respect of banking supervision and } \\
\text { supervisors. }\end{array}$ \\
\hline Principle 1(6) & $\begin{array}{l}\text { Cooperation. Arrangements for sharing information between supervisors and protecting } \\
\text { the confidentiality of such information should be in place. }\end{array}$ \\
\hline \multicolumn{2}{|r|}{ 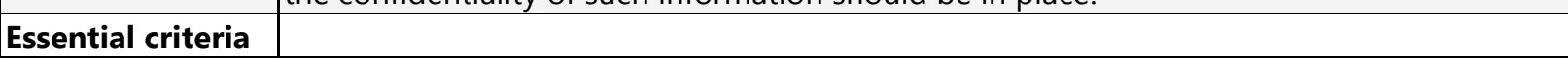 } \\
\hline EC1 & $\begin{array}{l}\text { Arrangements, formal or informal, are in place for cooperation and information sharing } \\
\text { between all domestic authorities with responsibility for the soundness of the financial } \\
\text { system, and there is evidence that these arrangements work in practice, where necessary. }\end{array}$ \\
\hline $\begin{array}{l}\text { Description and } \\
\text { findings re EC1 }\end{array}$ & $\begin{array}{l}\text { EU legislation provides the over-arching legal gateways for exchange of confidential } \\
\text { information between domestic authorities. At present, and following the introduction of } \\
\text { the "Twin Peaks" law there is a deficiency in the domestic legal provision for the exchange } \\
\text { of information between the FSMA and the NBB when acting in its supervisory capacity. } \\
\text { Such information is covered by professional secrecy constraints and requires a specific } \\
\text { exemption, which was omitted, in error, from the law and an amending instrument is } \\
\text { needed. It is hoped that this technical remedy can be achieved shortly, possibly by the end } \\
\text { of } 2012 \text {. } \\
\text { In practical terms exchange of information and cooperation continue at a working level - a } \\
\text { fact confirmed to the assessors by a range of NBB staff - and work has also taken place on } \\
\text { drafting a protocol (MoU) for formalizing the arrangements. At the time of the mission } \\
\text { discussions were continuing between the NBB and the FSMA on whether the protocol } \\
\text { could be agreed or whether refinements would be needed. }\end{array}$ \\
\hline
\end{tabular}




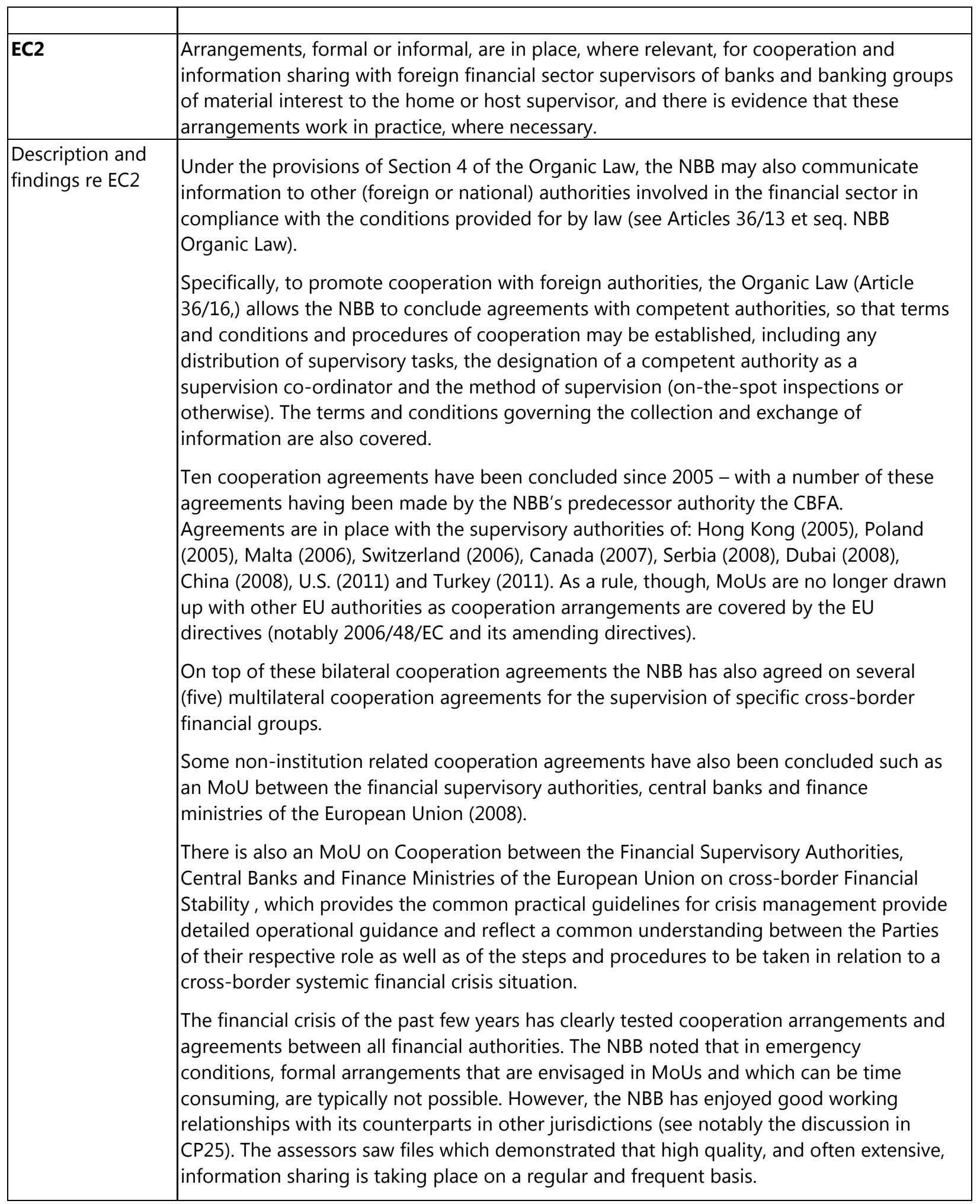




\begin{tabular}{|c|c|}
\hline EC3 & $\begin{array}{l}\text { The supervisor may provide confidential information to another domestic or foreign } \\
\text { financial sector supervisor. The supervisor must take reasonable steps to ensure that any } \\
\text { confidential information released to another supervisor will be used only for supervisory } \\
\text { purposes and will be treated as confidential by the receiving party. The supervisor receiving } \\
\text { confidential information from other supervisors is also required to take reasonable steps to } \\
\text { ensure that the confidential information will be used only for supervisory purposes and will } \\
\text { be treated as confidential. }\end{array}$ \\
\hline $\begin{array}{l}\text { Description and } \\
\text { findings re EC3 }\end{array}$ & $\begin{array}{l}\text { Again, under the provisions and conditions of Section } 4 \text { of the Organic Law, (Articles } 36 / 13 \\
\text { et seq) in accordance with Article } 44(2) \text { of Directive 2006/48/EC provides gateways for the } \\
\text { exchange of confidential information with non-domestic banking supervisory authorities or } \\
\text { other financial sector supervisors. The recipients must be subject to an equivalent } \\
\text { obligation of professional secrecy. }\end{array}$ \\
\hline EC4 & $\begin{array}{l}\text { The supervisor is able to deny any demand (other than a court order or mandate form a } \\
\text { legislative body) for confidential information in its possession. }\end{array}$ \\
\hline $\begin{array}{l}\text { Description and } \\
\text { findings re EC4 }\end{array}$ & $\begin{array}{l}\text { The relevant articles in the NBB Organic Law clearly stipulate that the NBB "may" share } \\
\text { confidential information. As such there is no legal obligation to do so. This is confirmed in } \\
\text { the explanatory documents, which clarify that the communication of confidential } \\
\text { information is an exception to the professional secrecy and is only a possibility, never an } \\
\text { obligation. }\end{array}$ \\
\hline $\begin{array}{l}\text { Assessment of } \\
\text { principle 1(6) }\end{array}$ & Compliant \\
\hline Comments & $\begin{array}{l}\text { The general framework for exchange of information is well articulated and there is } \\
\text { evidence, based on the assessors' reviews of files, that it is operational in practice. } \\
\text { It is important for the authorities to ensure that the drafting oversight in the Twin Peaks } \\
\text { law, which does not provide the formal exemption for the FSMA to exchange confidential } \\
\text { information with the NBB when the latter is acting in its capacity of supervisor, is remedied } \\
\text { at the earliest opportunity. The authorities aim to have the amendment in place before the } \\
\text { end of } 2012 \text {. It is particularly desirable for the NBB and the FSMA to conclude their } \\
\text { protocol governing their working arrangements and exchanges of information to ensure } \\
\text { that each authority has access to full, relevant information that it needs in the discharge of } \\
\text { its own responsibility. The assessors noted that the de facto working level relationships } \\
\text { exist and that exchanges of information have continued to take place, notwithstanding the } \\
\text { current technical legal anomaly. Were, however, the current situation to persist over time } \\
\text { without an MoU there is a clear risk that supervisory relationships might degrade to the } \\
\text { detriment of effective supervision and oversight of groups. }\end{array}$ \\
\hline Principle 2 & $\begin{array}{l}\text { Permissible activities. The permissible activities of institutions that are licensed and } \\
\text { subject to supervision as banks must be clearly defined and the use of the word "bank" in } \\
\text { names should be controlled as far as possible. }\end{array}$ \\
\hline
\end{tabular}




\begin{tabular}{|c|c|}
\hline Essential criteria & \\
\hline EC1 & The term "bank" is clearly defined in laws or regulations. \\
\hline $\begin{array}{l}\text { Description and } \\
\text { findings re EC1 }\end{array}$ & $\begin{array}{l}\text { The term "credit institution" is defined in Article } 1 \text { of the Banking Act. Deposit taking is } \\
\text { prohibited for any institution that is not authorized as a credit institution by the NBB under } \\
\text { Article } 4 \text { of the Banking Law. } \\
\text { The term "credit institution" is drawn from EU legislation (i.e., an institution that extends } \\
\text { credit and also takes deposits), which demands that all credit institutions must be } \\
\text { regulated under EU law. Article } 1 \text { of the Banking Law defines credit institutions as Belgian } \\
\text { or foreign companies whose activities-currently—consist in: 1) receiving deposits or other } \\
\text { repayable funds from the general public and offering credit for their own account; } 2 \text { ) issue } \\
\text { payment instruments under the form of electronic money. It may be noted that the } \\
\text { Electronic Money Law is expected to be amended and will then exclude this electronic } \\
\text { money issuance from the Banking Law and include it in legislation in payment institutions. }\end{array}$ \\
\hline EC2 & $\begin{array}{l}\text { The permissible activities of institutions that are licensed and subject to supervision as } \\
\text { banks are clearly defined either by supervisors, or in laws or regulations. }\end{array}$ \\
\hline & $\begin{array}{l}\text { A credit institution requires a license for the taking of deposits from the general public } \\
\text { and the offering of credit for their own account. At the point of application for a license, } \\
\text { the institution must submit a business plan outlining the planned activities to the NBB } \\
\text { who will permit or refuse authorization to conduct these activities. In principle a banking } \\
\text { license in Belgium provides comprehensive authorization for all activities listed. However, } \\
\text { when an institution wishes to embark on new activities post-licensing and where these } \\
\text { new activities would constitute a change in the basis for granting the license, it must also } \\
\text { notify the NBB who will assess the application typically via Article } 20 \text { of the Banking Law. } \\
\text { The main potential banking activities (a non-exhaustive list) are listed into the law to } \\
\text { facilitate the operation of the EU passport, which permits these activities to be carried out } \\
\text { in the single market if the credit institution has a license to perform these activities from } \\
\text { its home state authority. These activities are: } \\
\text { - } \\
\text { Acceptance of deposits and other repayable funds } \\
\text { - Lending including, inter alia: consumer credit, mortgage credit, factoring, with or } \\
\text { without recourse, financing of commercial transactions } \\
\text { - Financial leasing } \\
\text { - Money transmission services } \\
\text { - } \text { Issuing and administering means of payment (e.g., credit cards, travellers' cheques } \\
\text { and bankers' drafts) } \\
\text { Guarantees and commitments } \\
\text { Trading for own account or for account of customers in: } \\
\text { (a) money market instruments (cheques, bills, certificates of deposit, etc.); } \\
\text { (b) foreign exchange; } \\
\text { (c) financial futures and options; } \\
\text { (d) exchange and interest rate instruments; or } \\
\text { (e) transferable securities. }\end{array}$ \\
\hline
\end{tabular}




\begin{tabular}{|c|c|}
\hline & $\begin{array}{ll}\text { - } & \text { Participation in securities issues and the provision of services related to such issues } \\
- & \text { Advice to undertakings on capital structure, industrial strategy and related questions } \\
\text { - } & \text { Money broking } \\
\text { - } & \text { Portfolio management and advice } \\
\text { - } & \text { Safekeeping and administration of securities } \\
- & \text { Credit reference services } \\
- & \text { Safe custody services }\end{array}$ \\
\hline EC3 & $\begin{array}{l}\text { The use of the word "bank" and any derivations such as "banking" in a name is limited to } \\
\text { licensed and supervised institutions in all circumstances where the general public might } \\
\text { otherwise be misled. }\end{array}$ \\
\hline $\begin{array}{l}\text { Description and } \\
\text { findings re EC3 }\end{array}$ & $\begin{array}{l}\text { Only entities that possess a banking license may make use the word "bank," as protected } \\
\text { by Article } 6 \text { of the Banking Law. } \\
\text { Under the terms of the Banking Law the terms "credit institution," "bank," and any } \\
\text { derivations thereof may - in principle - only be used by a limited number of institutions } \\
\text { and namely by: } \\
\quad \text { - Belgian credit institutions; } \\
\quad \text { foreign credit institutions that perform tasks under the free provision of services or } \\
\quad \text { via the establishment of a branch office; } \\
\quad \text { representative offices. } \\
\text { Some exceptions to that rule exist, for instance: the NBB, the ECB, other international } \\
\text { public banking organizations, and also financial holding companies. } \\
\text { In practice, if the NBB becomes aware of a wrongful use of the term "bank" it will inform } \\
\text { the Office of the Public Prosecutor and the FSMA. In addition, in order to enable the NBB } \\
\text { to verify whether a transaction or an activity falls within the scope of the laws and } \\
\text { regulations it supervises, the NBB can formally require all necessary information from } \\
\text { institutions executing the transaction or performing the activity and any third party that } \\
\text { facilitates such transaction or activity on the basis of Article } 36 / 19 \text { of its organic law. This } \\
\text { information request is subject to penalties in case of non-compliance. There are no recent } \\
\text { examples of this power needing to be used in this context. } \\
\text { The FSMA also plays a role in the detection and prevention of illegal deposit taking firms } \\
\text { or activities. In accordance with the Law of } 2 \text { August } 2002 \text {, (Article } 45 \text {, section } 1 \text { ), the FSMA } \\
\text { is mandated "to contribute towards compliance with the rules aimed at protecting savers } \\
\text { and investors against the illegal offer or supply of financial products or services." The } \\
\text { FSMA, in its market surveillance, seeks to identify any solicitation of deposits or any } \\
\text { offering of investment services by unauthorized persons or companies. In addition to } \\
\text { acting promptly to close down the unlicensed activities, the FSMA will typically also issue } \\
\text { a warning to the general public (via press release and announcement on its website), } \\
\text { although there are no recent examples of the NBB or the FSMA having identified illegal } \\
\text { deposit taking. }\end{array}$ \\
\hline
\end{tabular}




\begin{tabular}{|c|c|}
\hline EC4 & $\begin{array}{l}\text { The taking of deposits from the public is generally reserved for institutions that are licensed } \\
\text { and subject to supervision as banks. }\end{array}$ \\
\hline $\begin{array}{l}\text { Description and } \\
\text { findings re EC4 }\end{array}$ & $\begin{array}{l}\text { The Banking Law requires credit institutions that take deposits from the public to be } \\
\text { licenced and subject to supervision. }\end{array}$ \\
\hline EC5 & $\begin{array}{l}\text { The supervisory or licensing authority publishes, and keeps current, a list of licensed banks } \\
\text { and branches of foreign banks operating within its jurisdiction. }\end{array}$ \\
\hline $\begin{array}{l}\text { Description and } \\
\text { findings re EC5 }\end{array}$ & $\begin{array}{l}\text { Article } 13 \text { of the Banking Law requires the NBB to establish a list of all licensed credit } \\
\text { institutions. The updated list is published on the NBB's website and is notified to the } \\
\text { European Commission. It is subdivided into sections (banks, saving banks, public banks, } \\
\text { investment banks). An annex to the list covers the Belgian financial holding companies. }\end{array}$ \\
\hline $\begin{array}{l}\text { Assessment of } \\
\text { Principle } 2\end{array}$ & Compliant \\
\hline Comments & $\begin{array}{l}\text { The legal framework provides clear definitions and not only the NBB but the FSMA, in their } \\
\text { activities, have regard to the importance of ensuring that the public is not misled into } \\
\text { placing deposits with institutions, which are not authorized for this purpose. }\end{array}$ \\
\hline Principle 3 & $\begin{array}{l}\text { Licensing criteria. The licensing authority must have the power to set criteria and reject } \\
\text { applications for establishments that do not meet the standards set. The licensing process, } \\
\text { at a minimum, should consist of an assessment of the ownership structure and governance } \\
\text { of the bank and its wider group, including the fitness and propriety of Board members and } \\
\text { senior management, its strategic and operating plan, internal controls and risk } \\
\text { management, and its projected financial condition, including its capital base. Where the } \\
\text { proposed owner or parent organization is a foreign bank, the prior consent of its home } \\
\text { country supervisor should be obtained. }\end{array}$ \\
\hline \multicolumn{2}{|r|}{ (1) } \\
\hline EC1 & $\begin{array}{l}\text { The licensing authority could be the banking supervisor or another competent authority. If } \\
\text { the licensing authority and the supervisory authority are not the same, the supervisor has } \\
\text { the right to have its views considered on each specific application. In addition, the licensing } \\
\text { authority provides the supervisor with any information that may be material to the } \\
\text { supervision of the licensed institution. }\end{array}$ \\
\hline $\begin{array}{l}\text { Description and } \\
\text { findings re EC1 }\end{array}$ & In Belgium the supervisory authority and the licensing authority are the same. \\
\hline EC2 & $\begin{array}{l}\text { The licensing authority has the power to set criteria for licensing banks. These may be } \\
\text { based on criteria set in laws or regulations. }\end{array}$ \\
\hline $\begin{array}{l}\text { Description and } \\
\text { findings re EC2 }\end{array}$ & $\begin{array}{l}\text { The conditions that have to be fulfilled in order to obtain a banking license from the NBB } \\
\text { are set out in the Banking Law in particular in the Articles } 15 \text { to } 22 \text {. These conditions relate } \\
\text { to the legal form of a credit institution, initial capital, shareholders, the management of } \\
\text { the credit institution, organizational requirements, the location of the head office and the } \\
\text { membership to a deposit guarantee system. } \\
\text { - } \quad \text { Legal form: Article } 15 \text { of the Banking Law requires that credit institutions are } \\
\text { established as commercial companies. } \\
\text { - Minimum initial capital: Article } 16 \text { of the Banking Law requires a fully deposited } \\
\text { minimum capital of } 6.2 \text { million euro. } \\
\text { - Shareholders: The NBB will only grant an banking license after being informed of the } \\
\text { identities of the shareholders or members, whether direct or indirect, natural or legal } \\
\text { persons, that have qualifying holdings, and of the amounts of those holdings (Article } \\
\text { 17). } \\
\text { - Leaders of the credit institution: The effective management of a credit institution must }\end{array}$ \\
\hline
\end{tabular}




\begin{tabular}{|c|c|}
\hline & 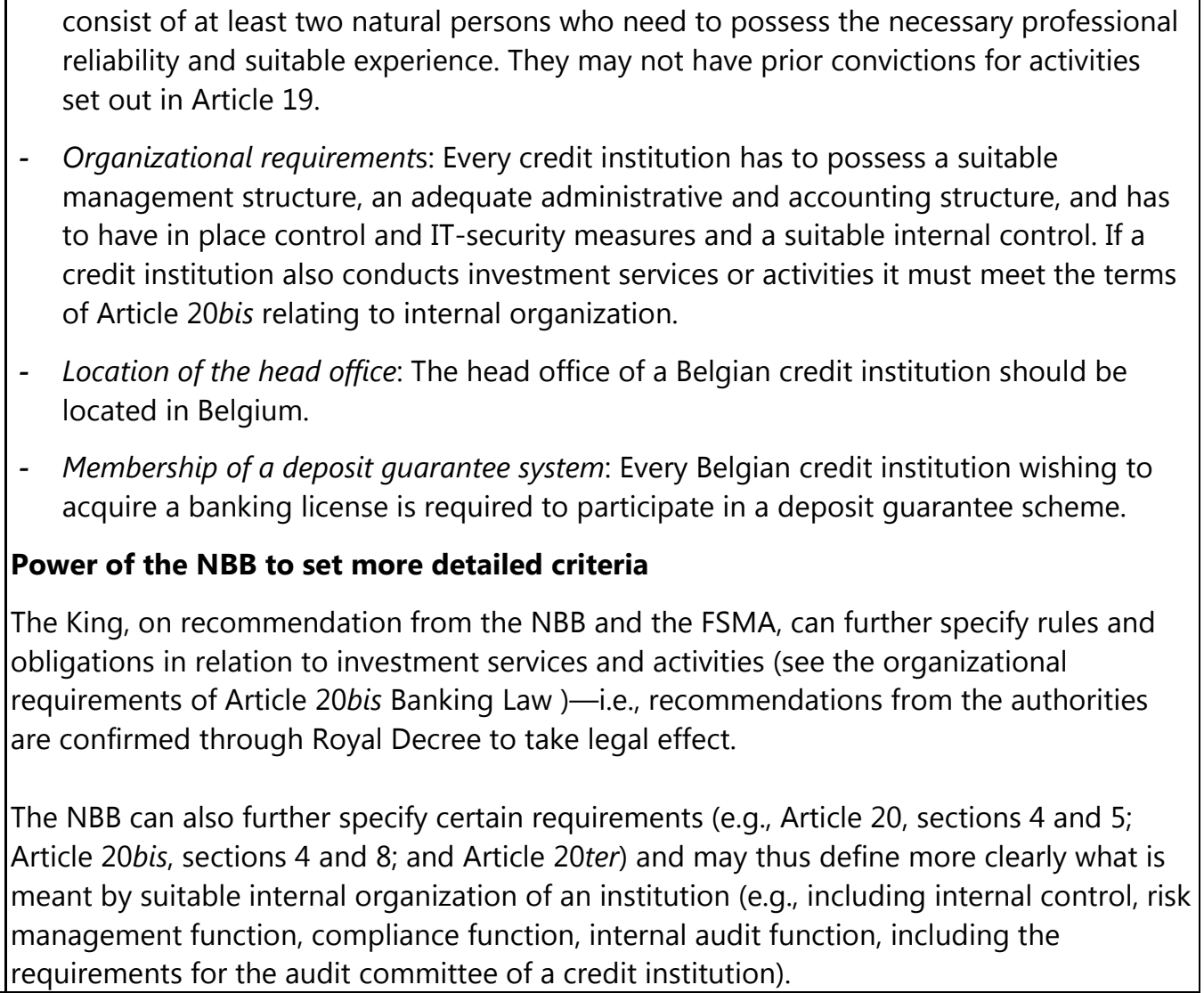 \\
\hline EC3 & The criteria for issuing licenses are consistent with those applied in ongoing supervision. \\
\hline $\begin{array}{l}\text { Description and } \\
\text { findings re EC3 }\end{array}$ & $\begin{array}{l}\text { The conditions for authorization are set out in the Banking Law (Articles 15-22) and must } \\
\text { be met on a continuing basis by the credit institution. }\end{array}$ \\
\hline EC4 & $\begin{array}{l}\text { The licensing authority has the power to reject an application if the criteria are not fulfilled } \\
\text { or if the information provided is inadequate. }\end{array}$ \\
\hline $\begin{array}{l}\text { Description and } \\
\text { findings re EC4 }\end{array}$ & $\begin{array}{l}\text { NBB has the discretionary power to assess the fulfillment of the criteria set out in the } \\
\text { Banking Law It must demonstrate its grounds for having made a decision in the case of a } \\
\text { refusal to grant a license. } \\
\text { The NBB has a Licensing Memorandum, which proposes a two phase procedure for } \\
\text { authorization as a credit institution incorporated in Belgium. The first phase is essentially a } \\
\text { screening phase and is not obligatory but firms are encouraged to use both phases as it is } \\
\text { likely to enhance the chances of a successful application. Similarly, candidates are } \\
\text { encouraged to discuss possible applications with the NBB even prior to embarking on } \\
\text { Phase one. } \\
\text { The first phase is a consideration of the conceptual proposal. Details which must be } \\
\text { included in this submission are listed in the memorandum. On the basis of its analysis, } \\
\text { which will include consultation with any other supervisory authorities who may be relevant } \\
\text { (for example if the credit institution were to be the subsidiary of another credit institution) } \\
\text { the NBB advises the applicant on whether there are issues that have been identified that } \\
\text { would stand in the way of a successful formal application or to invite the candidate to } \\
\text { submit a detailed, formal application which is phase two of the process. The conditions } \\
\text { and formalities that must be met in phase two are also set out in the memorandum. }\end{array}$ \\
\hline
\end{tabular}




\begin{tabular}{|c|c|}
\hline & $\begin{array}{l}\text { At the end of phase two, an accredited auditor or firm of auditors selected by the } \\
\text { applicants in consultation with the NBB but paid for by the candidate is required to } \\
\text { prepare a report to confirm that the conditions for obtaining an authorization have been } \\
\text { satisfied and that an appropriate organization has been developed. Additionally, the NBB } \\
\text { may perform its own on-site visits before making the final authorization decision. } \\
\text { Provided the institution satisfies the conditions laid down in Articles } 15 \text { to } 22 \text { of the } \\
\text { Banking Law the NBB will grant the authorization. When granting authorization, the NBB } \\
\text { may, in the interest of sound and prudent management, impose certain conditions/limits } \\
\text { on the exercise of certain of the activities proposed (Article } 11 \text { of the Banking Law). } \\
\text { A false declaration or the concealment of relevant details may give rise to administrative } \\
\text { sanctions against the enterprise or against the person or persons responsible for } \\
\text { providing the details. }\end{array}$ \\
\hline EC5 & $\begin{array}{l}\text { The licensing authority determines that the proposed legal, managerial, operational and } \\
\text { ownership structures of the bank and its wider group will not hinder effective supervision } \\
\text { on both a solo and a consolidated basis. }\end{array}$ \\
\hline $\begin{array}{l}\text { Description and } \\
\text { findings re EC5 }\end{array}$ & $\begin{array}{l}\text { The Banking Law provides that, as part of the licensing criteria, the governance structure } \\
\text { and organization of a credit institution must be appropriate to the activities and services } \\
\text { proposed. Article } 20 \text { is the legal provision on which the NBB bases its governance policy for } \\
\text { credit institutions (and for financial institutions in general). Section } 7 \text { of Article } 20 \text { provides } \\
\text { that if the credit institution has close links with legal or natural persons these links must not } \\
\text { be an impediment to the prudential supervision of the credit institution on an individual or } \\
\text { solo basis. } \\
\text { A credit institution's governance structure must be tailored to the nature, size, complexity } \\
\text { and risk profile (Article } 20 \text { sections 1-2). } \\
\text { A credit institution has to establish a governance structure at both solo and group level. } \\
\text { Supervision of a firm's governance is based on a combination of legally binding minimum } \\
\text { requirements as laid down in the Banking Law and further detailed supervisory guidance as } \\
\text { laid down in circulars. In } 2007, \text { the former CBFA published a cross-sectoral so-called } \\
\text { "Internal Governance Circular" (PPB-2007-6-CPB-CPA on the CBFA's prudential } \\
\text { expectations on financial institutions' sound governance, March 2007). This Circular is still } \\
\text { in force and expresses the supervisor's prudential expectations (based again on the } \\
\text { principle of proportionality) for an institution's governance structure and organization. } \\
\text { The credit institution must (under Article } 20 \text { and as elaborated in the Circular) submit a } \\
\text { governance memorandum to the NBB and in the memorandum describe its governance } \\
\text { structure including a discussion of the choices it has made. The NBB does not formally } \\
\text { "approve" a governance memorandum, but gives its "nihil obstat," often combined with } \\
\text { further recommendations to improve the governance structure and organization. The } \\
\text { assessors were able to review several governance memorandum as well as a "scorecarding" } \\
\text { assessment (see CP19) of governance within an institution. }\end{array}$ \\
\hline EC6 & $\begin{array}{l}\text { The licensing authority identifies and determines the suitability of major shareholders, } \\
\text { including the ultimate beneficial owners, and others that may exert significant influence. It } \\
\text { also assesses the transparency of the ownership structure and the sources of initial capital. }\end{array}$ \\
\hline
\end{tabular}




\begin{tabular}{|c|c|}
\hline $\begin{array}{l}\text { Description and } \\
\text { findings re EC6 }\end{array}$ & $\begin{array}{l}\text { Article } 17 \text { of the Banking Law requires the NBB to assess the suitability of direct and } \\
\text { indirect (solo or jointly) qualifying shareholders of an institution upon authorization. } \\
\text { Authorization shall be refused if the NBB has any reason to believe that the shareholders } \\
\text { are not able to offer guarantees with regard to the sound and prudent management of } \\
\text { the credit institution. } \\
\text { The NBB checks the ultimate beneficial owners as well as the sources of initial capital. }\end{array}$ \\
\hline EC7 & A minimum initial capital amount is stipulated for all banks. \\
\hline $\begin{array}{l}\text { Description and } \\
\text { findings re EC7 }\end{array}$ & $\begin{array}{l}\text { Articles } 16 \text { and } 23 \text { specify a minimum level of capital of EUR6.2mn. Grandfathering of } \\
\text { institutions with lower capital than the minimum threshold is permitted legally but no such } \\
\text { institutions remain in Belgium. }\end{array}$ \\
\hline EC8 & $\begin{array}{l}\text { The licensing authority, at authorization, evaluates proposed directors and senior } \\
\text { management as to expertise and integrity (fit and proper test), and any potential for } \\
\text { conflicts of interest. The fit and proper criteria include: (i) skills and experience in relevant } \\
\text { financial operations commensurate with the intended activities of the bank; and (ii) no } \\
\text { record of criminal activities or adverse regulatory judgments that make a person unfit to } \\
\text { uphold important positions in a bank. }\end{array}$ \\
\hline $\begin{array}{l}\text { Description and } \\
\text { findings re EC8 }\end{array}$ & $\begin{array}{l}\text { The Banking Law provides that the NBB shall verify whether the persons in charge of the } \\
\text { bank's "senior management" (de facto often the equivalent of "members of the } \\
\text { management committee") are fit and proper and have the adequate experience to carry } \\
\text { out their functions. The assessment of the qualities required, in particular as regards the } \\
\text { necessary expertise and the adequate experience, are also applied to "persons taking part } \\
\text { in the direction or management without participating in the senior management" (de facto } \\
\text { the non-executive directors) (Article18 of the Banking Law ). Furthermore, the Banking Law } \\
\text { (Article 19) states that the directors and managers of the credit institution must not have } \\
\text { convictions or have been prohibited from carrying out their profession. } \\
\text { Banks are required to notify the NBB in advance of any proposal for the appointment, } \\
\text { renewal (or non-renewal) or dismissal of directors and senior managers in the institution's } \\
\text { company officers; of any information and documents necessary to assess the qualities } \\
\text { required of them; and, where applicable, of the distribution of tasks within the governing } \\
\text { bodies (Article 26bis of the Banking Law). } \\
\text { The Circular on the exercise of external functions by directors and managers (PPB-2006-13- } \\
\text { CPB-CPA) provides a definition of senior management, which, broadly, includes the } \\
\text { directors of a board and members of a management committee of a board (if this } \\
\text { committee is established) and any persons who are identified by that management } \\
\text { committee as senior management. } \\
\text { The Circular also includes the concept of "Key staff," which is defined as any person, other } \\
\text { than a senior manager, who fulfills a key function (secretary general, legal affairs, human } \\
\text { resources, communication) or is in charge of independent control functions (such as } \\
\text { internal audit, compliance and risk management). This group of individuals are currently } \\
\text { not formally subject to fit and proper assessment but in practice are often informally } \\
\text { screened. In particular the CFO or CRO of an institution would be subject to assessment if } \\
\text { the CFO/CRO position does not fall within the definition of senior management for that } \\
\text { bank. }\end{array}$ \\
\hline
\end{tabular}


Conflicts of interests, their prevention and management, must be subject to an internal policy of the bank - see principle VIII of the Internal Governance Circular (see EC5 above).

Individuals subject to fit and proper assessments must submit forms to the NBB at the initial appointment to their role and at any subsequent renewal of their mandate. The forms seek to identify information regarding experience and skill as well as integrity and reputation.

- Regarding experience and competence, required details include: education, professional experience in and outside the financial sector, reasons why previous professional posts have ended, the tasks and duties of the new position and so on.

- Regarding integrity/reputation, required details include: any convictions and continuing inquiries that are relevant for supervisory purposes, previous prudential assessments, administrative and disciplinary sanctions and so on.

The assessment is intended as in-depth exercise of judgment and can involve extensive deliberations. At present an interview can be requested by the NBB and in the future interviews are likely to become standard practice for a limited group of persons i.e., members of the management committee, chairperson of the board and chairpersons of specialized committees within the board. It is proposed that these interviews will be held by the Governor or another member of the NBB's Board of Directors.

The fit and proper regime at the NBB was under review at the time of the mission. The NBB had been giving considerable thought to revising the regulation and practices of assessing fit and proper for individuals in credit institutions including clarifying the understanding that individuals must meet such standards on a continuing basis and that the NBB might initiate more frequent checks in the future. A draft Circular had already been prepared for the Board to consider prior to an open consultation with the industry. The key changes in regulation and practice are likely to be:

- A widened scope of application of the fit and proper assessment to include persons responsible for independent control functions (i.e., risk management, internal control and compliance);

- Confirming the obligation of the credit institution to inform the NBB of any material issue that might negatively affect the consideration of a person who is required to be 'fit and proper'.

- More consistent use of interviews with senior NBB staff.

To prepare the new Circular, a major stock-taking exercise of all significant fit \& proper during the last five years was undertaken, in addition to international standards and practices of some other jurisdictions to obtain a deeper understanding of what is intended by "adequate competence \& experience" (= "fit") and "good reputation" ("proper").

In discussion with NBB staff it was clear that much reflection has been given to how skills might be assessed effectively and consistency and the challenges of establishing a view on integrity. The new approach would provide more structure to assess potentially difficult situations. The NBB emphasized that the primary responsibility for appointing suitable persons rests with the institution. 


\begin{tabular}{|c|c|}
\hline & $\begin{array}{l}\text { Internally the NBB has already undertaken some restructuring to create a centralized } \\
\text { function that can systematise the assessment of fit and proper. The changes are intended } \\
\text { to support enhanced efficiency, consistency and depth of analysis. The NBB Board of } \\
\text { Directors must make the final decision on "fit and proper" and now receives advice from } \\
\text { the central unit, which is supplemented by the advice of the relevant supervisory team for } \\
\text { the institution in question. The dual approach is intended to apply a "four eyes" principle } \\
\text { and also to ensure that firm specific expertise is used in cases where more detailed follow } \\
\text { up may be necessary. In view of the likely broadening of the application of fit and proper } \\
\text { testing, the increased efficiency of the centralized function will be valuable. The NBB is also } \\
\text { revising the forms that individuals must complete. }\end{array}$ \\
\hline EC9 & $\begin{array}{l}\text { The licensing authority reviews the proposed strategic and operating plans of the bank. } \\
\text { This includes determining that an appropriate system of corporate governance, risk } \\
\text { management and internal controls, including those related to the detection and prevention } \\
\text { of criminal activities, as well as the oversight of proposed outsourced functions, will be in } \\
\text { place. The operational structure is required to reflect the scope and degree of } \\
\text { sophistication of the proposed activities of the bank }\end{array}$ \\
\hline & $\begin{array}{l}\text { Pursuant to Article } 8 \text { of the Banking Law authorization is granted on the basis of the } \\
\text { assessment of a business plan, which includes a description of the future activities of the } \\
\text { institution and pro formal financial statements and projections.(See also EC10). } \\
\text { As mentioned under EC5, governance arrangements are also scrutinized. Proportionality is } \\
\text { key when setting up and supervising governance arrangements. The institution must } \\
\text { always take into account its size, nature and complexity of its activities (see Article 20, } \\
\text { section } 1 \text {, second paragraph). } \\
\text { Internal control functions (audit, risk management, compliance) must be part of the } \\
\text { governance arrangements a bank must set up; the bank must describe them in its } \\
\text { governance memorandum. (See also CP 17). } \\
\text { Outsourcing arrangements must be in line with the guidelines set out in the "Outsourcing } \\
\text { Circular" (PPB 2004/5). }\end{array}$ \\
\hline EC10 & $\begin{array}{l}\text { The licensing authority reviews pro formal financial statements and projections for the } \\
\text { proposed bank. This includes an assessment of the adequacy of the financial strength to } \\
\text { support the proposed strategic plan as well as financial information on the principal } \\
\text { shareholder of the bank. }\end{array}$ \\
\hline $\begin{array}{l}\text { Description and } \\
\text { findings re EC10 }\end{array}$ & $\begin{array}{l}\text { As noted under EC9 above, Article } 8 \text { of the Banking Law requires that authorization is } \\
\text { contingent upon a suitable business plan, which includes a description of the future } \\
\text { activities, and pro formal financial statements and projections. The NBB requires pro forma } \\
\text { data including projections and sensitivity analysis (covering 2-3 years) to assist its } \\
\text { evaluation of whether the institution may be viable and have sufficient capital to support } \\
\text { the proposed plan on a stand-alone basis. If that is not the case, the license will not be } \\
\text { granted. } \\
\text { The fit and proper character of main shareholders is also evaluated during the licensing } \\
\text { process (and on an ongoing basis). This includes the ability of shareholders to support the } \\
\text { bank if needed (see Article } 24 \text { of the Banking Law). } \\
\text { The assessors discussed a case with NBB staff in which an authorization had been refused } \\
\text { due to the funding arrangements and financial strength of a proposed shareholder. }\end{array}$ \\
\hline
\end{tabular}




\begin{tabular}{|c|c|}
\hline EC11 & $\begin{array}{l}\text { In the case of foreign banks establishing a branch or subsidiary, before issuing a license, } \\
\text { the host supervisor establishes that no objection (or a statement of no objection) from the } \\
\text { home supervisor has been received. For purposes of the licensing process, as well as } \\
\text { ongoing supervision of cross-border banking operations in its country, the host supervisor } \\
\text { assesses whether the home supervisor practices global consolidated supervision. }\end{array}$ \\
\hline & 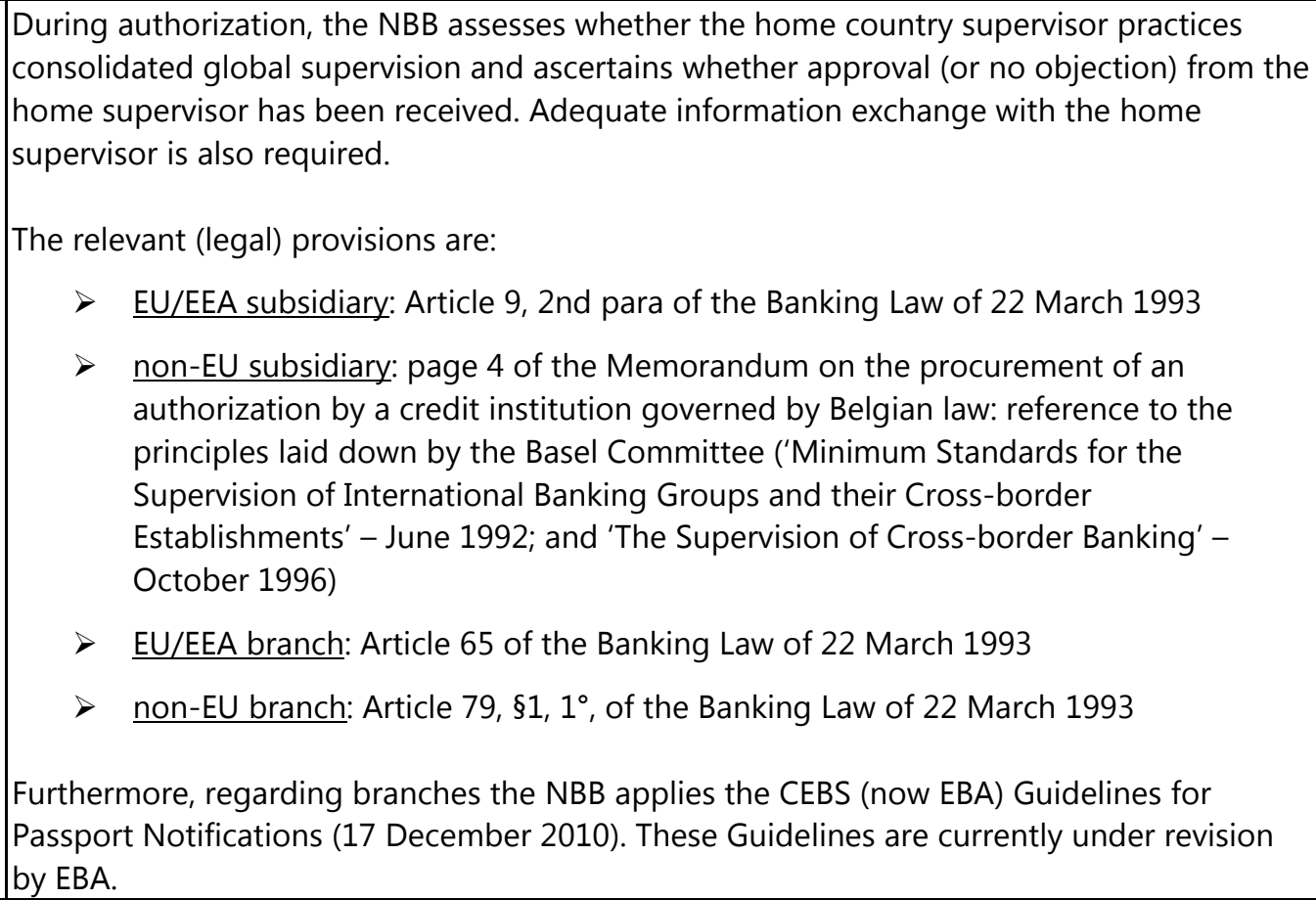 \\
\hline EC12 & $\begin{array}{l}\text { If the licensing, or supervisory, authority determines that the license was based on false } \\
\text { information, the license can be revoked. }\end{array}$ \\
\hline $\begin{array}{l}\text { Description and } \\
\text { findings re } E C 12\end{array}$ & $\begin{array}{l}\text { False declaration or the concealment of relevant details can give rise to administrative and } \\
\text { penal sanctions against the enterprise or against the person or persons responsible for } \\
\text { providing the details. The NBB noted that in such circumstances close consideration } \\
\text { would be given to whether direct revocation was the most appropriate course of action or } \\
\text { whether one of the NBB's other remedial powers might be suitable. For example, in a } \\
\text { situation where it were uncovered that the shareholder(s) was not fit and proper, the NBB } \\
\text { might consider using powers under Article } 25 \text { of the Banking Law to divest the } \\
\text { shareholder of its holding in the credit institution. }\end{array}$ \\
\hline EC13 & $\begin{array}{l}\text { The board, collectively, must have a sound knowledge of each of the types of activities the } \\
\text { bank intends to pursue and the associated risks. }\end{array}$ \\
\hline & $\begin{array}{l}\text { Besides the "fitness" of individuals the NBB can also assess collective "fitness," i.e., whether } \\
\text { the board as a whole possesses sufficient relevant knowledge and experience, and whether } \\
\text { tasks within the board are appropriately divided. Such screening most often happens in the } \\
\text { course of more general governance inspections. This collective aspect will be more } \\
\text { explicitly expressed through the future fit and proper policy, but is already reflected in } \\
\text { supervisory circulars. For example, at present, the Internal Governance Circular (paragraph } \\
\text { 52), explains that the criteria envisaged by the supervisory authority for assessing the } \\
\text { qualities required of non-executive directors will be applied both collectively and on an } \\
\text { individual basis. The NBB discussed with the assessors the need for there to be a } \\
\text { continuous assessment of the suitable composition of the board of the institution. This } \\
\text { should not necessitate a full formal review every time a board appointment was made, but } \\
\text { the NBB would always review the appointment. For example, failure to ensure a key skill }\end{array}$ \\
\hline
\end{tabular}




\begin{tabular}{|c|c|}
\hline & $\begin{array}{l}\text { was covered at the board would trigger follow up. It was noted that the composition of the } \\
\text { board was primarily the responsibility of the institution. It was essential to ensure that the } \\
\text { firms were undertaking their own assessment and not relying on supervisory scrutiny and } \\
\text { approval, even though this was necessary and important function of the supervisors. }\end{array}$ \\
\hline \multicolumn{2}{|l|}{$\begin{array}{l}\text { Additional } \\
\text { criteria }\end{array}$} \\
\hline AC1 & $\begin{array}{l}\text { The assessment of the application includes the ability of the shareholder to supply } \\
\text { additional financial support, if needed. }\end{array}$ \\
\hline $\begin{array}{l}\text { Description and } \\
\text { findings re } A C 1\end{array}$ & $\begin{array}{l}\text { The NBB may evaluate, on this basis of its assessment under Article } 8 \text { of the Banking Law } \\
\text { whether the institution is viable and has sufficient capital to support the proposed plan on } \\
\text { a stand-alone basis. If this is not the case, the license will not be granted. The ability of the } \\
\text { shareholder to supply additional financial support is part of this evaluation. } \\
\text { The fit and proper character of main shareholders is also evaluated during the licensing } \\
\text { process (and on an ongoing basis). This includes the ability of shareholders to support the } \\
\text { bank if needed (see article } 24 \text { of the Banking Law). } \\
\text { As noted above in EC10 the assessors discussed a case with NBB staff in which an } \\
\text { authorization had been refused due to the funding arrangements and financial strength of } \\
\text { a proposed shareholder. }\end{array}$ \\
\hline AC2 & $\begin{array}{l}\text { The licensing or supervisory authority has policies and processes in place to monitor the } \\
\text { progress of new entrants in meeting their business and strategic goals, and to determine } \\
\text { that supervisory requirements outlined in the license approval are being met. }\end{array}$ \\
\hline $\begin{array}{l}\text { Description and } \\
\text { findings re AC2 }\end{array}$ & $\begin{array}{l}\text { There are no specific policies in respect of supervisory practice relating to a new credit } \\
\text { institution. The intensity of the supervisory process will be assessed as part of the normal } \\
\text { risk based supervisory planning cycle. The assessors discussed a case in which it had been } \\
\text { decided that quarterly updates had to be provided to the Board in part to monitor } \\
\text { progress in relation to a number of conditions that had been placed on the credit } \\
\text { institution as a condition of its authorization. }\end{array}$ \\
\hline $\begin{array}{l}\text { Assessment of } \\
\text { Principle } 3\end{array}$ & Compliant \\
\hline Comments & $\begin{array}{l}\text { The NBB are to be commended on their rational and thoughtful review of fit and proper } \\
\text { policies and practices. Despite planned changes to the regulatory architecture of the EU } \\
\text { (details of which were not confirmed at the time of the mission) it is hoped that the NBB } \\
\text { will be able to institute further changes, following internal and external consultation, and } \\
\text { benefit from a deeper and more meaningful (as well as consistent) approach in this field. }\end{array}$ \\
\hline Principle 4 & $\begin{array}{l}\text { Transfer of significant ownership. The supervisor has the power to review and reject any } \\
\text { proposals to transfer significant ownership or controlling interests held directly or indirectly } \\
\text { in existing banks to other parties. }\end{array}$ \\
\hline \multicolumn{2}{|r|}{ (1) } \\
\hline EC1 & $\begin{array}{l}\text { Laws or regulations contain clear definitions of "significant" ownership and "controlling } \\
\text { interest." }\end{array}$ \\
\hline $\begin{array}{l}\text { Description and } \\
\text { findings re } E C 1\end{array}$ & $\begin{array}{l}\text { While the Banking Law does not itself contain definitions of "control," "participation," } \\
\text { "parent company," or "subsidiary" but instead refers to other instruments, including the } \\
\text { Royal Decree of } 23 \text { September } 1993 \text { and the Company Law Code in which these } \\
\text { definitions may be found (Article 3, section 1, point } 2 \text { and Article 44). } \\
\text { The definition of control is set out in the Company Law Code, articles } 5 \text { to } 12 \text {. Moreover, } \\
\text { the NBB extends its scrutiny of the concept of control to any entity, which exercises a } \\
\text { dominant influence. }\end{array}$ \\
\hline
\end{tabular}




\begin{tabular}{|c|c|}
\hline & $\begin{array}{l}\text { For prudential purposes participation is presumed to exist in case of a direct or indirect } \\
\text { holding of } 20 \text { percent. } \\
\text { The Banking Law does define the term "qualified holding" (Article 3, section 1, point 3). A } \\
\text { qualifying holding means a direct or indirect holding in an undertaking, which represents } \\
10 \text { percent or more of the capital or of the voting rights or which makes it possible to } \\
\text { exercise a significant influence over the management of that undertaking. This is } \\
\text { consistent with the definition of a qualifying holding under the European Capital } \\
\text { Requirements Directive (CRD). }\end{array}$ \\
\hline $\mathrm{EC2}$ & $\begin{array}{l}\text { There are requirements to obtain supervisory approval or provide immediate notification of } \\
\text { proposed changes that would result in a change in ownership, including beneficial } \\
\text { ownership, or the exercise of voting rights over a particular threshold or change in } \\
\text { controlling interest. }\end{array}$ \\
\hline $\begin{array}{l}\text { Description and } \\
\text { findings re EC2 }\end{array}$ & 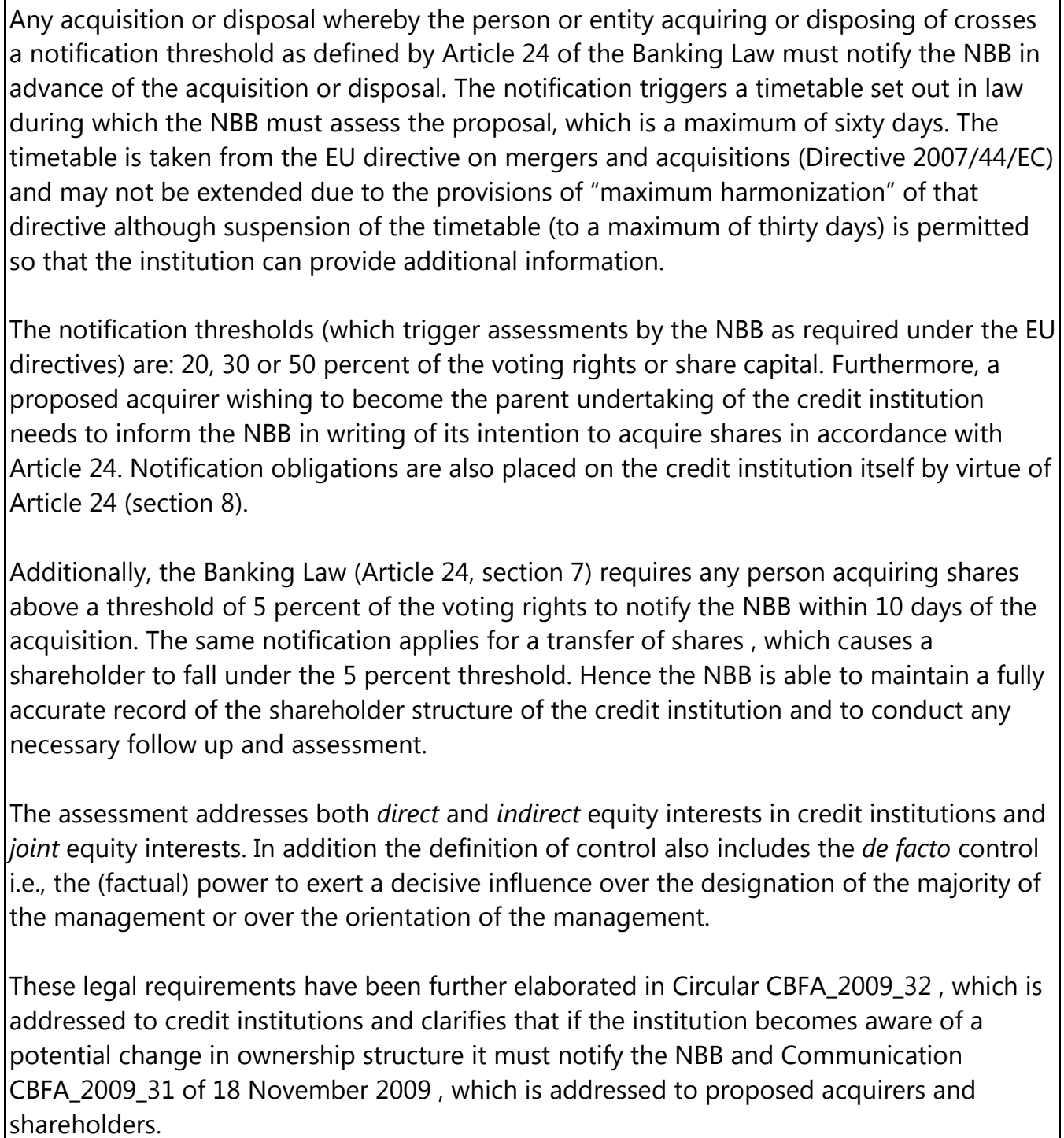 \\
\hline
\end{tabular}




\begin{tabular}{|c|c|}
\hline EC3 & $\begin{array}{l}\text { The supervisor has the power to reject any proposal for a change in significant ownership, } \\
\text { including beneficial ownership, or controlling interest, or prevent the exercise of voting } \\
\text { rights in respect of such investments, if they do not meet criteria comparable to those used } \\
\text { for approving new banks. }\end{array}$ \\
\hline $\begin{array}{l}\text { Description and } \\
\text { findings re EC3 }\end{array}$ & $\begin{array}{l}\text { The Banking Law grants the NBB powers (Article 24, section 3) to assess candidates who } \\
\text { propose to acquire a qualifying holding. If the NBB has not made a decision by the end of } \\
\text { the assessment period it shall be deemed not to have objected. However, the NBB can } \\
\text { object to the proposal on the grounds of incomplete information. The Banking Law } \\
\text { similarly grants the NBB the power of objection. In the event that the application is refused, } \\
\text { an appropriate statement of the grounds for the decision may be made public at the } \\
\text { request of the proposed purchaser. }\end{array}$ \\
\hline EC4 & $\begin{array}{l}\text { The supervisor obtains from banks, through periodic reporting or on-site examinations, the } \\
\text { names and holdings of all significant shareholders or those that exert controlling influence, } \\
\text { including the identities of beneficial owners of shares being held by nominees, custodians } \\
\text { and through vehicles which might be used to disguise ownership. }\end{array}$ \\
\hline \multirow[t]{4}{*}{$\begin{array}{l}\text { Description and } \\
\text { findings re EC4 }\end{array}$} & $\begin{array}{l}\text { The threshold of notification to the NBB for any changes in shareholding is } 5 \text { percent } \\
\text { (Article 24, section } 8 \text { of the Banking Law). The notification must be made within } 10 \text { days of } \\
\text { the change. Under the same legal provision, an institution must also provide an annual } \\
\text { notification to the NBB of the shareholders who have directly or indirectly (and } \\
\text { individually or collectively) have a qualifying holding. The annual submission must also } \\
\text { cover acquisitions and disposals of shares that were not required to have been notified at } \\
\text { the time of the transaction. }\end{array}$ \\
\hline & $\begin{array}{l}\text { A standard reporting format for this information is issued by the NBB a qualifying holding. } \\
\text { The chairman of the board of directors of the institution must countersign the submission } \\
\text { of information on shareholders (provision of false or incomplete information can result in } \\
\text { penalty sanction). }\end{array}$ \\
\hline & $\begin{array}{l}\text { The NBB has recently informed firms that it is adopting a more vigorous "look through" } \\
\text { approach in its assessment of shareholders. The NBB indicated that it would seek to look } \\
\text { through corporate and trust structures. }\end{array}$ \\
\hline & $\begin{array}{l}\text { Additionally, the FSMA is responsible, as the market supervisor, for applying transparency } \\
\text { requirements set out in the Law of } 2 \text { May } 2007 \text { (Title II) regarding the disclosure of major } \\
\text { holdings issuers whose shares are listed in a regulated market. The law transposes the EU } \\
\text { transparency directive. }\end{array}$ \\
\hline EC5 & $\begin{array}{l}\text { The supervisor has the power to take appropriate action to modify, reverse or otherwise } \\
\text { address a change of control that has taken place without the necessary notification to or } \\
\text { approval from the supervisor. }\end{array}$ \\
\hline \multirow[t]{2}{*}{$\begin{array}{l}\text { Description and } \\
\text { findings re EC5 }\end{array}$} & $\begin{array}{l}\text { In the event that the legal notification has not been made for a change of control, Article } \\
24 \text {, section } 6 \text { of the Banking Law provides that that on submission of notification from the } \\
\text { NBB, the President of the Commercial Court, can annul all or part of the decisions taken } \\
\text { by the general assembly of shareholders (in accordance with Article 516, section } 3 \text { of the } \\
\text { Companies Code). }\end{array}$ \\
\hline & $\begin{array}{l}\text { The NBB has not had any experience of this situation arising, however, if the NBB has } \\
\text { reasonable grounds to consider that a person possessing a qualified holding could } \\
\text { hamper the sound and prudent management of the credit institution, Article } 25 \text { of the } \\
\text { Banking Law gives the NBB the right to impose certain measures, such as divesting the } \\
\text { shareholder of his shares or suspending his voting rights. }\end{array}$ \\
\hline
\end{tabular}




\begin{tabular}{|c|c|}
\hline & $\begin{array}{l}\text { In accordance with the Banking Law (Article } 104 \text {, section } 1 \text { ), any person who deliberately } \\
\text { omits to notify the NBB as required by Article } 24 \text { or ignores the objection of the NBB in } \\
\text { this respect or the suspension of the voting rights as foreseen via Article } 25 \text {, may be } \\
\text { subject to criminal sanctions, although the NBB is not the authority that exercises these } \\
\text { specific powers. }\end{array}$ \\
\hline \multicolumn{2}{|l|}{$\begin{array}{l}\text { Additional } \\
\text { criteria }\end{array}$} \\
\hline AC1 & $\begin{array}{l}\text { Laws and regulations provide, or the supervisor ensures, that banks must notify the } \\
\text { supervisor as soon as they become aware of any material information, which may } \\
\text { negatively affect the suitability of a major shareholder. }\end{array}$ \\
\hline $\begin{array}{l}\text { Description and } \\
\text { findings re } \mathrm{ACl}\end{array}$ & $\begin{array}{l}\text { Primary legislation currently does not require a bank to inform the NBB if it would become } \\
\text { aware of any material information, which may negatively affect the suitability of one of its } \\
\text { major shareholders, namely with regard to (i) reputation; (ii) financial soundness; (iii) the } \\
\text { bank's ability to meet its prudential requirements; and (iv) suspicion of money laundering } \\
\text { or financing of terrorism. }\end{array}$ \\
\hline $\begin{array}{l}\text { Assessment of } \\
\text { Principle } 4\end{array}$ & Compliant \\
\hline Comments & $\begin{array}{l}\text { The change of control of an authorized institution is largely governed by EU law, however } \\
\text { not all elements of this principle are captured in EU directives. Broadly, however, the NBB's } \\
\text { application of policies and procedures in this area are comprehensive and it is noticeable } \\
\text { that there is an increasing focus on looking "upwards" through the shareholding and } \\
\text { ownership structure above the institution. Nevertheless the authorities are urged to } \\
\text { remedy the lack of legal obligation for a credit institution to notify its supervisory } \\
\text { authority of a material adverse development that may negatively affect the suitability of a } \\
\text { major shareholder. The assessors welcomed the authorities' indication that appropriate } \\
\text { changes could be put in place on the occasion of the next Banking Law's modification, } \\
\text { which was expected to be soon. }\end{array}$ \\
\hline Principle 5 & $\begin{array}{l}\text { Major acquisitions. The supervisor has the power to review major acquisitions or } \\
\text { investments by a bank, against prescribed criteria, including the establishment of cross- } \\
\text { border operations, and confirming that corporate affiliations or structures do not expose } \\
\text { the bank to undue risks or hinder effective supervision. }\end{array}$ \\
\hline \multicolumn{2}{|l|}{ Essential criteria } \\
\hline EC1 & $\begin{array}{l}\text { Laws or regulations clearly define what types and amounts (absolute and/or in relation to a } \\
\text { bank's capital) of acquisitions and investments need prior supervisory approval. }\end{array}$ \\
\hline $\begin{array}{l}\text { Description and } \\
\text { findings re EC1 }\end{array}$ & $\begin{array}{l}\text { The legal framework in Belgium distinguishes between institutions, which are deemed to be } \\
\text { systemically relevant and those which are not. In brief, there are clear thresholds and } \\
\text { powers for the NBB to be pre-notified and approve acquisitions by systemic institutions. } \\
\text { These are subject to some pre-notification and pre-approval requirements but the regime } \\
\text { is more complex and is not complete. } \\
\text { With respect to systemically relevant institutions: } \\
\text { The NBB is obliged under the NBB Organic Law (Article 36/3, section 2) to determine, which } \\
\text { institutions are systemically relevant. These institutions are, in turn, required to submit any } \\
\text { strategic decision to the NBB for approval. The NBB must specify (and publish), which } \\
\text { decisions are to be deemed as strategic, though it should be noted that the legal provision } \\
\text { itself states that strategic decisions should be understood to mean: }\end{array}$ \\
\hline
\end{tabular}




\begin{tabular}{|c|c|}
\hline & $\begin{array}{l}\text { "notably decisions to acquire or establish another institutions, to set up a joint venture } \\
\text { established in another state, to conclude cooperation agreements or agreements on capital } \\
\text { investment or acquisition of a branch of activity, merger or demerger" } \\
\text { The Circular (CREFS_2010_01) provides the guidance forseen under the NBB Organic Law, } \\
\text { and establishes that decisions, which have an impact exceeding the following thresholds } \\
\text { shall be deemed systemic: of investment of at least10 percent of the total consolidated } \\
\text { balance sheet or income and revenue or } 5 \text { percent of capital and reserves. } \\
\text { For non-systemic institutions: } \\
\text { Article } 33 \text { bis of the Banking Law provides that any credit institution which plans to acquire } \\
\text { or create a non-domestic subsidiary must provide advance notification to the NBB. The } \\
\text { period of notice is not specified in the legislation. } \\
\text { Further, Article } 30 \text { states that mergers or transfers of assets between domestic credit } \\
\text { institutions or between credit institutions and financial institutions are subject to prior } \\
\text { approval by the NBB. If the supervisory authority fails to act within a } 3 \text { month period its } \\
\text { approval will be deemed to have been given. } \\
\text { Additionally, there are certain limits in place on shareholdings and participations which } \\
\text { would, de facto, impose some constraint on the nature and magnitude of possible } \\
\text { acquisitions. Shareholding and participations held by credit institutions are regulated via } \\
\text { Article } 32 \text { (in particular section } 5 \text { ) of the Banking Law, which defines the conditions and } \\
\text { limits for such shareholdings and participations. Section } 5 \text { provided that no single } \\
\text { shareholding may exceed } 10 \text { percent and that the total amount of all shareholdings may } \\
\text { not exceed } 35 \text { percent of its own funds. A credit institution may never own qualifying } \\
\text { holdings exceeding } 15 \text { percent of its own funds and the total amount of all shareholdings } \\
\text { may never exceed } 60 \text { percent of these own funds. Article } 32 \text { also provides a trading book } \\
\text { exemption so that shares in trading portfolios would not be regarded as an acquisition. }\end{array}$ \\
\hline EC2 & Laws or regulations provide criteria by which to judge individual proposals. \\
\hline $\begin{array}{l}\text { Description and } \\
\text { findings re EC2 }\end{array}$ & $\begin{array}{l}\text { Article } 30 \text { of the Banking Law provides that the NBB can refuse authorization of merger or } \\
\text { transfer of activities on the grounds of concerns relating to sound and prudent } \\
\text { management in the case of mergers between credit institutions or the transfer of activities } \\
\text { between credit institutions or credit institutions and other financial institutions. } \\
\text { For the systemically relevant institutions there are broad criteria stated in the NBB Organic } \\
\text { Law (Article 36/3, section 2), namely whether the proposals would "go against sound and } \\
\text { prudent management of the system-relevant financial institution or are liable to have a } \\
\text { significant effect on the stability of the financial system." } \\
\text { As touched on in EC1, mergers and acquisitions involving credit institutions and non- } \\
\text { financial institutions do not require regulatory pre-approval (unless the credit institution in } \\
\text { question was a systemic institution). However, once the NBB is aware of such an acquisition } \\
\text { and were the authority to have concerns, the acquisition may be considered ex post by the } \\
\text { NBB and assessed against the general conditions of the Banking Law (Article } 20 \text { which sets } \\
\text { out minimum requirements for credit institutions). }\end{array}$ \\
\hline
\end{tabular}




\begin{tabular}{|c|c|}
\hline & $\begin{array}{l}\text { Also as noted above (EC1), Article } 32 \text { of the Banking Law sets out the conditions and limits } \\
\text { under which a credit institution may own shareholdings (directly or indirectly) in other } \\
\text { undertakings, although these are restrictions on the credit institutions rather than criteria } \\
\text { with which to judge the suitability of a specific proposal. }\end{array}$ \\
\hline EC3 & $\begin{array}{l}\text { Consistent with licensing requirements, among the objective criteria that the supervisor } \\
\text { uses is that any new acquisitions and investments do not expose the bank to undue risks or } \\
\text { hinder effective supervision. The supervisor can prohibit banks from making major } \\
\text { acquisitions / investments (including the establishment of foreign branches or subsidiaries) } \\
\text { in countries with secrecy laws or other regulations prohibiting information flows deemed } \\
\text { necessary for adequate consolidated supervision }\end{array}$ \\
\hline $\begin{array}{l}\text { Description and } \\
\text { findings re EC3 }\end{array}$ & $\begin{array}{l}\text { The extent to which the NBB has legal powers to prohibit major acquisitions or investments } \\
\text { made by credit institutions is discussed under EC1 above. } \\
\text { As discussed above (EC1) systemically relevant institutions must submit strategic decisions } \\
\text { to the NBB and may be opposed if considered to have the potential to undermine the } \\
\text { soundness of the institution or of financial stability in general. } \\
\text { Further, and in respect of all credit institutions, Article } 30 \text { of the Banking Law provides that } \\
\text { the NBB can refuse authorization of merger or transfer of activities on the grounds of } \\
\text { concerns relating to sound and prudent management in the case of mergers between } \\
\text { credit institutions or the transfer of activities between credit institutions or credit } \\
\text { institutions and other financial institutions. } \\
\text { The NBB can object to the establishment of a non-domestic branch of an institution under } \\
\text { Article } 34 \text { of the Banking Law The grounds for objection include an adverse impact on the } \\
\text { organization, financial position or supervision of the credit institution. When establishing a } \\
\text { foreign subsidiary, the credit institution must pre-notify the NBB (pursuant to Article 33bis } \\
\text { of the Banking Law ). Pre-notification allows the NBB the opportunity to investigate } \\
\text { whether the non-domestic subsidiary might have an adverse impact on the credit } \\
\text { institution and the NBB enjoys wide powers, if necessary, to prevent a credit institution's } \\
\text { activities. In deciding whether to invoke such powers, the NBB would consider whether the } \\
\text { establishment of the non-domestic subsidiary was compatible with the requirements of } \\
\text { Article } 20, \text { which sets out a range of organizational requirements. Finally, the "close links" } \\
\text { requirement (Article 20, section } 7 \text { of the Banking Law ) provides a further legal power to the } \\
\text { NBB to object if the "close links" of the credit institution were to hinder the individual or } \\
\text { consolidated supervision on the said institution. }\end{array}$ \\
\hline EC4 & $\begin{array}{l}\text { The supervisor determines that the bank has, from the outset, adequate financial and } \\
\text { organizational resources to handle the acquisition/investment. }\end{array}$ \\
\hline $\begin{array}{l}\text { Description and } \\
\text { findings re EC4 }\end{array}$ & $\begin{array}{l}\text { On a legal basis, Article } 30 \text { of the Banking Law provides the NBB with the power to deny a } \\
\text { merger or acquisition involving other financial institutions on grounds related to the sound } \\
\text { and prudent management of a credit institution, (providing that the objection is made } \\
\text { within three months of having been notified). } \\
\text { The NBB can object to an acquisition or investment on the grounds set out in Article } 20 \text { of } \\
\text { the Banking Law regarding organizational requirements for example if the establishment of } \\
\text { foreign subsidiaries or branches would compromise a suitable management structure, } \\
\text { administrative and accountancy organization, control and security measures with regard to } \\
\text { electronic data-processing or internal control of the concerned credit institution. }\end{array}$ \\
\hline
\end{tabular}




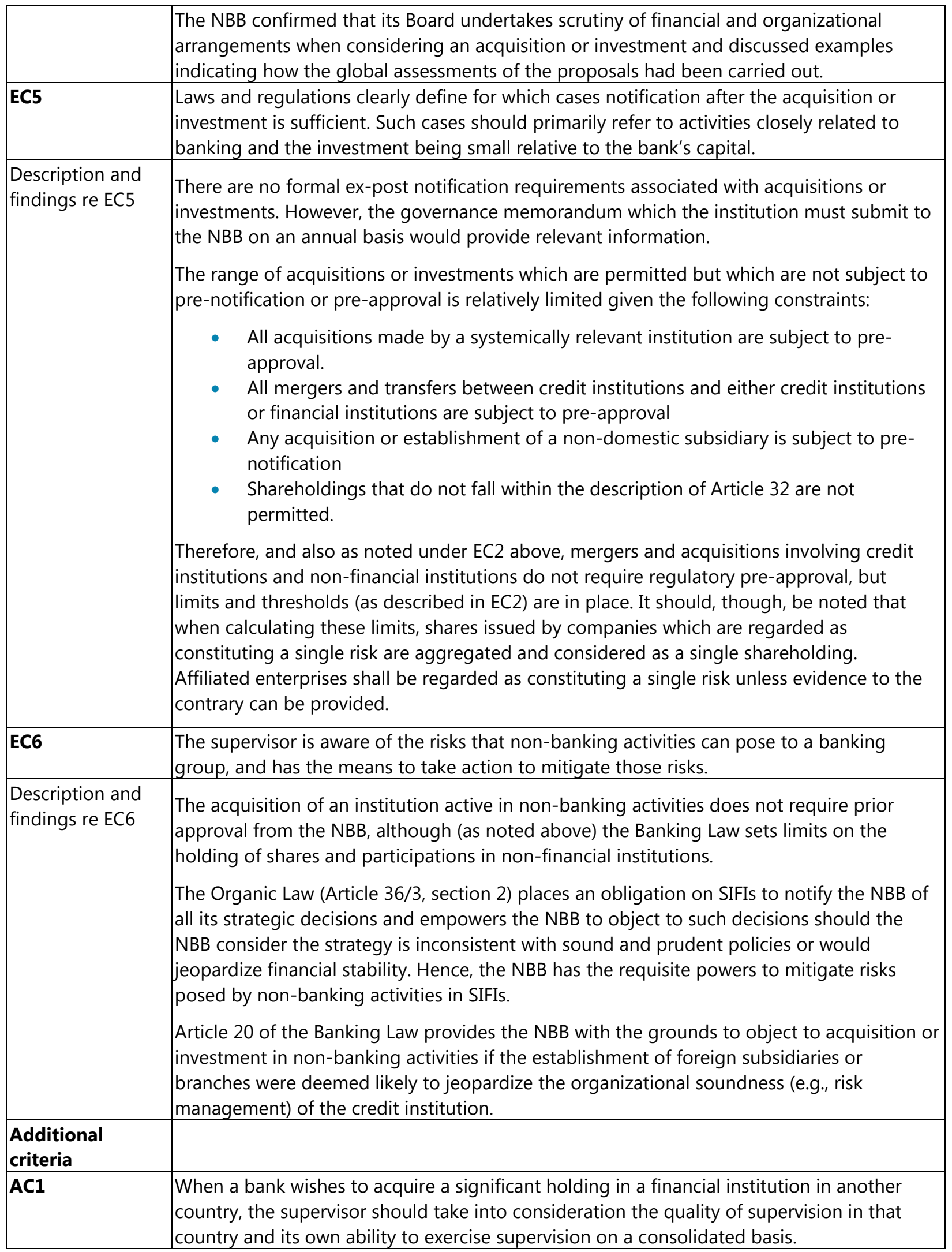




\begin{tabular}{|c|c|}
\hline $\begin{array}{l}\text { Description and } \\
\text { findings re } A C 1\end{array}$ & $\begin{array}{l}\text { Although there is no explicit law or regulation requiring this, the NBB confirmed that it } \\
\text { would take the quality of supervision of a host jurisdiction into account when assessing a } \\
\text { major acquisition. The NBB further indicated that its practice was to establish relationships } \\
\text { and MoUs as necessary with relevant host jurisdictions to facilitate supervision (noting that } \\
\text { the MoU itself could not be signed with a jurisdiction that was non-compliant with key } \\
\text { elements such as professional secrecy requirements). }\end{array}$ \\
\hline $\begin{array}{l}\text { Assessment re } \\
\text { Principle } 5\end{array}$ & Largely Compliant. \\
\hline Comments & $\begin{array}{l}\text { The requirements of this principle are met in relation to the systemically relevant } \\
\text { institutions, largely due to the NBB's extensive powers to scrutinize and, if necessary, object } \\
\text { to strategic decisions made by systemically relevant institutions. For the much smaller non- } \\
\text { systemically relevant sector of the market, the principle is largely but not wholly met. The } \\
\text { degree of non-compliance is not extensive and relates to the potential to undertake a } \\
\text { major acquisition in a non-financial sector without either pre-notification or pre-approval } \\
\text { requirements being in place. It is recognized that there are a range of mitigating factors } \\
\text { already in place, including extensive powers of ex poste intervention by the NBB if deemed } \\
\text { necessary, a baseline of reporting to the NBB provided by the governance memorandum } \\
\text { and also the fact that there are clear limits placed on investments that may be made in } \\
\text { non-financial sectors. Furthermore, a credit institution obtains its authorization on the basis } \\
\text { of its program of operations, which in the case of a major acquisition in a non-financial } \\
\text { sector could be considered to occur. While notification requirements are not imposed on } \\
\text { firms, a departure from their approved program of operations is likely to promote } \\
\text { disclosure of intention by the firm to the supervisor before the acquisition takes place. } \\
\text { Nonetheless, it is recommended that at minimum pre-notification procedures are put in } \\
\text { place. In the interests of completeness and over-arching regulatory clarity and } \\
\text { transparency, it is recommended that the NBB be given powers of pre-approval for any } \\
\text { acquisition or investment that exceeds a defined benchmark. The } 5 \text { percent threshold, } \\
\text { which is a commonly used standard to denote significant shareholdings might be a suitable } \\
\text { benchmark to consider. }\end{array}$ \\
\hline Principle 6 & $\begin{array}{l}\text { Capital adequacy. Supervisors must set prudent and appropriate minimum capital } \\
\text { adequacy requirements for banks that reflect the risks that the bank undertakes, and must } \\
\text { define the components of capital, bearing in mind its ability to absorb losses. At least for } \\
\text { internationally active banks, these requirements must not be less than those established in } \\
\text { the applicable Basel requirement. }\end{array}$ \\
\hline \multicolumn{2}{|l|}{ Essential criteria } \\
\hline EC1 & $\begin{array}{l}\text { Laws and regulations require all banks to calculate and consistently maintain a minimum } \\
\text { capital adequacy ratio. Laws, regulations or the supervisor define the components of } \\
\text { capital, ensuring that emphasis is given to those elements of capital available to absorb } \\
\text { losses. }\end{array}$ \\
\hline
\end{tabular}




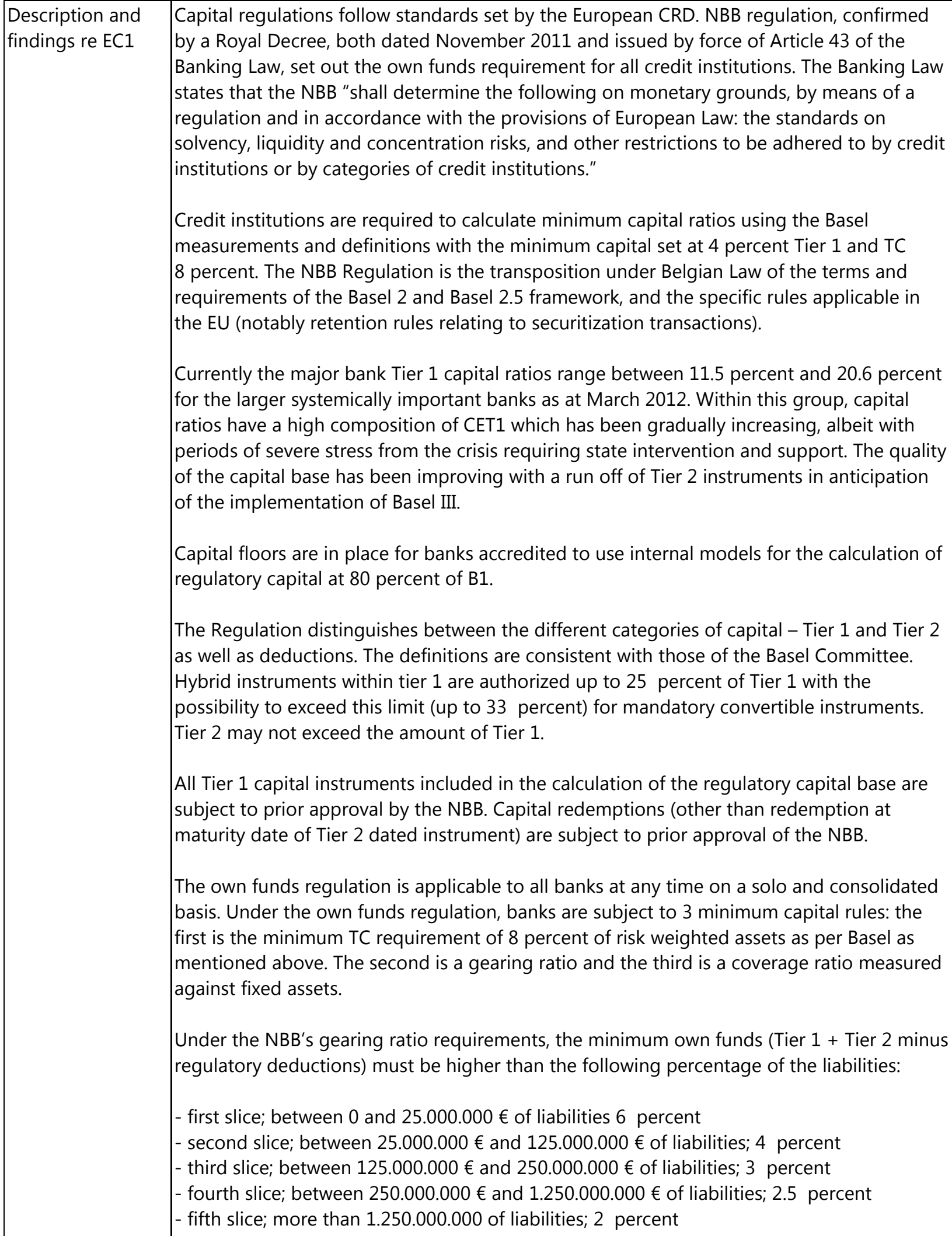

The Regulation distinguishes between the different categories of capital - Tier 1 and Tier 2 as well as deductions. The definitions are consistent with those of the Basel Committee. Hybrid instruments within tier 1 are authorized up to 25 percent of Tier 1 with the possibility to exceed this limit (up to 33 percent) for mandatory convertible instruments. Tier 2 may not exceed the amount of Tier 1.

All Tier 1 capital instruments included in the calculation of the regulatory capital base are subject to prior approval by the NBB. Capital redemptions (other than redemption at maturity date of Tier 2 dated instrument) are subject to prior approval of the NBB.

The own funds regulation is applicable to all banks at any time on a solo and consolidated basis. Under the own funds regulation, banks are subject to 3 minimum capital rules: the first is the minimum TC requirement of 8 percent of risk weighted assets as per Basel as mentioned above. The second is a gearing ratio and the third is a coverage ratio measured against fixed assets.

Under the NBB's gearing ratio requirements, the minimum own funds (Tier $1+$ Tier 2 minus regulatory deductions) must be higher than the following percentage of the liabilities:

- first slice; between 0 and $25.000 .000 €$ of liabilities 6 percent

- second slice; between $25.000 .000 €$ and $125.000 .000 €$ of liabilities; 4 percent

- third slice; between $125.000 .000 €$ and $250.000 .000 €$ of liabilities; 3 percent

- fourth slice; between $250.000 .000 €$ and $1.250 .000 .000 €$ of liabilities; 2.5 percent

- fifth slice; more than 1.250 .000 .000 of liabilities; 2 percent 
Under the coverage ratio, own funds (Tier $1+$ Tier 2 - deductions) must be higher than fixed assets that are not already deduced from own funds.

The own funds reporting requirements for credit institutions described in the Banking Law requires each credit institution to provide the NBB on a regular basis with a detailed and comprehensive calculation of its regulatory capital requirement in respect of its specific risk profile.

Capital requirements cover credit, market and operational risk as Pillar 1 risks. The methodology to calculate risk weighted assets is consistent with the Basel 2 and Basel 2.5 framework. The NBB will consider besides the Pillar 1 risks also Pillar 2 risks as part of its annual SREP and assessment of banks' ICAAP.

The NBB receives quarterly reports on capital adequacy as well as six monthly and annual accounts audited by the external auditor. Included in the annual accounts is the bank's analysis of its specific risk profile; inputs for such analysis are both quantitative and qualitative and are drawn from prudential reporting, external audit reports and assessments by NBB-inspectors. The result of the analysis is reflected in the RAS (Scorecarding tool) and is used to set, if necessary, additional capital requirements (Pillar 2 process) to individual banks.

Prudential filters applied by the NBB include: unrealized gains and losses on AFS bonds portfolio are neutralized; unrealized gains on AFS equity portfolio are recognized in Tier 2 (unrealized losses are deduced from Tier 1); and Deferred tax assets are deduced when they exceed 10 percent of tier 1 (with the exception of DTA relating to unrealized losses on AFS bond portfolio that are neutralized).

At present, the NBB-services are preparing a revision of the CAD-requirements in view of the new EU-proposals relating to the transposition of the Basel III framework.

A feature of the Belgium banking sector that was problematic during the crisis involved the practice of banks granting credit to shareholders to subscribe to the capital of the bank where repayment of the loan depended on the proceeds the shareholder received from the capital instrument. The implication of this practice is the effective absorption capacity of capital.

Article II. 1 of the own funds regulation was amended in 2010 to clarify the requirements relating to the deduction of credits to shareholders. Article II.1 states that if the institution provides funding directly or indirectly to the shareholder to subscribe to acquire a capital instrument of the bank, the corresponding amount of capital is not recognized in equity. While capital will be deducted for instances of this practice after 31 December 2010, those capital instruments continue to be included and will commence being deducted from 1 January 2014 at a rate of 20 percent per year until fully deducted bv 1 January 2018. The result being that at the time of the review, the amounts that had been accrued prior to December 2010 continued to be counted in the capital base of banks that are published.

While the own funds regulation has been amended, at the time of the mission, these amounts are still being included in the published capital ratios for systemically important banks. This weakens the transparency of the true loss absorbency of capital. 


\begin{tabular}{|c|c|}
\hline & $\begin{array}{l}\text { While the investment is deducted when Pillar } 2 \text { capital ratios are assessed, published capital } \\
\text { ratios are artificially inflated. } \\
\text { Paragraph } 49 \text { (i) of the Basel II capital framework states that "the key element of capital on } \\
\text { which the main emphasis should be placed is equity capital and disclosed reserves. This key } \\
\text { element of capital is the only element common to all countries' banking systems; it is } \\
\text { wholly visible in the published accounts and is the basis on which most market judgments } \\
\text { of capital adequacy are made; and it has a crucial bearing on profit margins and a bank's } \\
\text { ability to compete. This emphasis on equity capital and disclosed reserves reflects the } \\
\text { importance the Committee attaches to securing an appropriate quality, and the level, of the } \\
\text { total capital resources maintained by major banks." } \\
\text { EC1 explicitly refers to the need for the regulations to emphasize those elements of capital } \\
\text { that absorb losses. The NBB was clearly aware of this risk and had adjusted the risk } \\
\text { assessment process when setting minimum capital adequacy ratios. }\end{array}$ \\
\hline EC2 & $\begin{array}{l}\text { At least for internationally active bank, the definition of capital, the method of calculation } \\
\text { and the ratio required are not lower than those established in the applicable Basel } \\
\text { requirement. }\end{array}$ \\
\hline $\begin{array}{l}\text { Description and } \\
\text { findings re EC2 }\end{array}$ & $\begin{array}{l}\text { The definition of capital, the method of calculation and required minimum ratios are the } \\
\text { same for all credit institutions and are based on the European Capital Requirements } \\
\text { Directive (CRD). The Basel II.5 requirements implemented in CRD3 are in effect in Europe } \\
\text { and implemented in Belgium. } \\
\text { In terms of Basel III, banks are implementing transition plans to comply with the definitions, } \\
\text { and higher ratios. } \\
\text { In calculating risk weighted assets, banks are authorized to use a standardized method or } \\
\text { an internal model (IRB approach) with the prior approval of the NBB. Under the } \\
\text { standardized approach, the risk weight is a function of the external rating of the } \\
\text { counterparty. Under the internal approach the risk weight is a function of the internal rating } \\
\text { of the counterparty and the loss given default. Banks may also use a model to estimate the } \\
\text { loss given default. } \\
\text { For market risk, banks may use a standardized or an internal model (VaR) to calculate risk } \\
\text { weighted assets. Under the internal model approach, banks may estimate the capital } \\
\text { requirements relating to the general and the specific market risk of their trading positions } \\
\text { subject to the prior authorization of the NBB. } \\
\text { For operational risk, banks have the option of using a basic indicator approach, the } \\
\text { standardized approach or an internal model approach (AMA). Under the standardized } \\
\text { approach the operational risk requirement is a percentage of the average revenues of the } \\
\text { institution (the percentage is set in function of the activities). The use of the AMA approach } \\
\text { is subject to the prior authorization of the NBB. } \\
\text { Revaluation gains, when related to equities or real estates may be accounted as part of Tier } \\
\text { 2. Tier } 2 \text { may not represent more than } 100 \text { percent of Tier } 1 . \text { In terms of prudential filters, } \\
\text { the main deductions are: }\end{array}$ \\
\hline
\end{tabular}




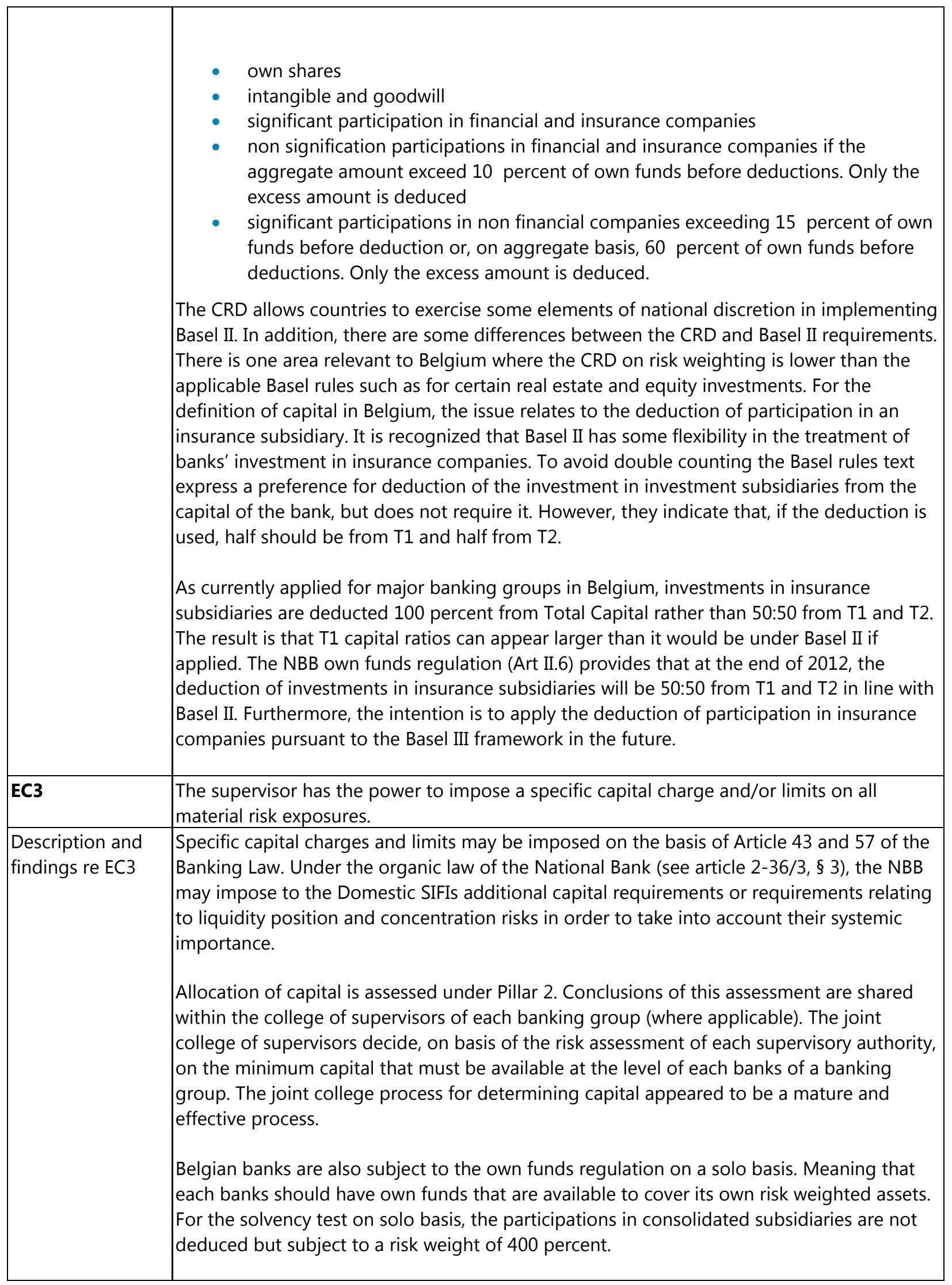




\begin{tabular}{|c|c|}
\hline EC4 & $\begin{array}{l}\text { The required capital ratio reflects the risk profile of individual banks. Both on-balance sheet } \\
\text { and off-balance sheet risks are included. }\end{array}$ \\
\hline $\begin{array}{l}\text { Description and } \\
\text { findings re EC4 }\end{array}$ & $\begin{array}{l}\text { The minimum capital ratios are calculated based on the Basel II methodology for Pillar } 1 \\
\text { and cover credit, market and operational risks. The methodology takes into account the } \\
\text { amount of the exposures and the risks of these exposures. All exposures (on and off } \\
\text { balance, derivatives) are taken into account for the calculation of minimum capital } \\
\text { requirements. } \\
\text { The specific risk profile of the institution is assessed by the NBB and, on basis of this } \\
\text { assessment, NBB sets capital add-ons above the minimum capital requirements in order to } \\
\text { take into account the risks not captured by the minimum capital requirements (Pillar } 2 \\
\text { approach). The main objective of the capital assessment by the NBB is to determine } \\
\text { whether "an institution has sufficient capital/own funds, as well as an adequate } \\
\text { policy/process on the matter, to face its current and future risks." An important feature of } \\
\text { the capital assessment is that it is forward looking. }\end{array}$ \\
\hline EC5 & $\begin{array}{l}\text { Capital adequacy requirements take into account the conditions under which the banking } \\
\text { system operates. Consequently, laws and regulations in a particular jurisdiction may set } \\
\text { higher capital adequacy standards than the applicable Basel requirements. }\end{array}$ \\
\hline $\begin{array}{l}\text { Description and } \\
\text { findings re EC5 }\end{array}$ & $\begin{array}{l}\text { The NBB may set higher capital requirements on basis of its Pillar } 2 \text { assessment. The Pillar } 2 \\
\text { assessment is a well defined process within the NBB's supervisory framework. } \\
\text { All banks will be assessed through the risk scorecarding tool which is at the centre of the } \\
\text { risk assessment process. The scorecard captures both quantitative and qualitative metrics } \\
\text { across a range of categories. The scorecard will take into account both bank specific but } \\
\text { also environmental factors into the assessment. } \\
\text { In addition to the output from the risk scorecard, the supervisor will assess the ICAAP. The } \\
\text { ICAAP assessment will potentially involve an offsite inspection or onsite review, an } \\
\text { assessment of the Pillar } 1 \text { estimates from the bank (and economic capital numbers if } \\
\text { available) and an evaluation of approaches to the calculation of Pillar } 1 \text { capital such as risk } \\
\text { diversification, model risk etc. In addition to the ICAAP assessment, the results of stress } \\
\text { testing are taken into consideration and so is the capital needs under the SREP. Interest } \\
\text { rate risk in the banking book is a Pillar } 2 \text { risk. In general, the worse result of the three tests } \\
\text { will be used as the capital add-on. Through this process, the capital decision takes into } \\
\text { consideration a full range of risks. }\end{array}$ \\
\hline EC6 & $\begin{array}{l}\text { Laws or regulations clearly give the supervisor authority to take measures should a bank fall } \\
\text { below the minimum capital ratio. }\end{array}$ \\
\hline
\end{tabular}




\begin{tabular}{|c|c|}
\hline $\begin{array}{l}\text { Description and } \\
\text { findings re EC6 }\end{array}$ & $\begin{array}{l}\text { Article } 43 \text { s3 states that "If the Bank deems that a credit institution's policy on its own funds } \\
\text { requirement is not appropriate to the institution's risk profile, it may, without prejudice to } \\
\text { the provisions of Article 57, with regard to the goals mentioned in Article } 1 \text { of this Law, lay } \\
\text { down requirements on solvency, liquidity, concentration risks and risk positions in addition } \\
\text { to those mentioned in s1."Art } 57 \text { stipulates that "if the NBB finds that a credit institution is } \\
\text { not operating in accordance with the provisions of this Law.....or does not have sufficient } \\
\text { guarantees of its solvency.....it shall determine the deadline within which the situation must } \\
\text { be rectified." The law gives the NBB broad powers to remedy if a bank falls below minimum } \\
\text { capital ratios. }\end{array}$ \\
\hline EC7 & $\begin{array}{l}\text { Where the supervisor permits banks to use internal assessments of risk as inputs to the } \\
\text { calculation of regulatory capital, such assessments must adhere to rigorous qualifying } \\
\text { standards and be subject to the approval of the supervisor. If banks do not continue to } \\
\text { meet these qualifying standards on an ongoing basis, the supervisor may revoke its } \\
\text { approval of the internal assessments. }\end{array}$ \\
\hline $\begin{array}{l}\text { Description and } \\
\text { findings re EC7 }\end{array}$ & $\begin{array}{l}\text { The use of internal models to calculate regulatory capital is subject to the prior approval of } \\
\text { the NBB. The qualifying standards are defined in the own funds regulations and are in line } \\
\text { with the Basel II and II. } 5 \text { frameworks. } \\
\text { The requirements are identical to those proposed by the Basel Committee. Each internal } \\
\text { model must be approved formally by the NBB before using it for the capital calculations. } \\
\text { With regard to internationally active banking groups, the decision to approve a model is } \\
\text { made after consultation with relevant supervisors as was evidenced through the } \\
\text { documentation (within the college of supervisors). } \\
\text { The approval is only granted if the banks meet all the criteria of the regulation. These } \\
\text { criteria relate to the use test, governance and risk management framework, independence } \\
\text { of risk management and development of internal models, the adequacy of the rating } \\
\text { system, the internal validation process, the documentation, the data collection, the } \\
\text { conservatism of the different estimates. Belgium has } 8 \text { banks approved to use internal } \\
\text { models for credit risk, } 3 \text { for operational risk and } 4 \text { banks approved for market risk. At the } \\
\text { time of approving an internal model to calculate regulatory capital, the NBB will attach } \\
\text { conditions to the approval to allow for periodic monitoring of the model and assess results } \\
\text { of implementation. }\end{array}$ \\
\hline \multicolumn{2}{|l|}{$\begin{array}{l}\text { Additional } \\
\text { criteria }\end{array}$} \\
\hline AC1 & $\begin{array}{l}\text { For non-internationally active banks, the definition of capital, the method of calculation and } \\
\text { the capital required are broadly consistent with the principles of applicable Basel } \\
\text { requirements relevant to internationally active banks. }\end{array}$ \\
\hline $\begin{array}{l}\text { Description and } \\
\text { findings re } A C 1\end{array}$ & $\begin{array}{l}\text { There is no difference between the minimum capital requirements rules for internationally } \\
\text { or non-internationally active banks. As discussed in EC2, the own funds regulation differs } \\
\text { from Basel II in relation to the deduction of investments in insurance subsidiaries, however } \\
\text { the NBB has taken steps to align regulations with BII and BIII. }\end{array}$ \\
\hline AC2 & $\begin{array}{l}\text { For non-internationally active banks and their holding companies, capital adequacy ratios } \\
\text { are calculated and applied in a manner generally consistent with the applicable Basel } \\
\text { requirement, as set forth in the footnote to the Principle. }\end{array}$ \\
\hline
\end{tabular}




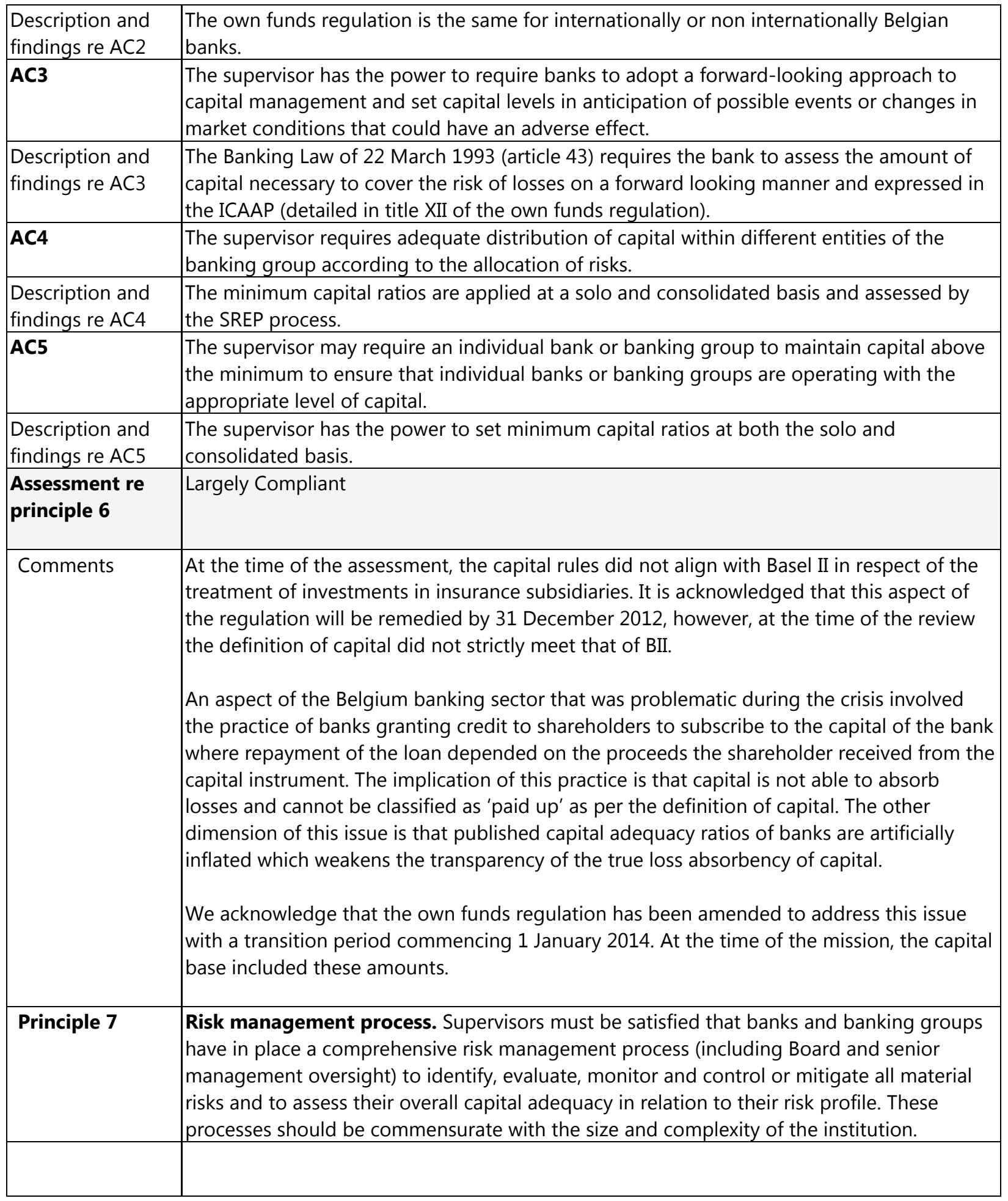




\begin{tabular}{|c|c|}
\hline EC1 & $\begin{array}{l}\text { Individual banks and banking groups are required to have in place comprehensive risk } \\
\text { management policies and processes to identify, evaluate, monitor and control or mitigate } \\
\text { material risks. The supervisor determines that these processes are adequate for the size and } \\
\text { nature of the activities of the bank and the banking group and are periodically adjusted in } \\
\text { the light of the changing risk profile of the bank or banking group and external market } \\
\text { developments. If the supervisor determines that the risk management processes are } \\
\text { inadequate, it has the power to require a bank or banking group to strengthen them. }\end{array}$ \\
\hline $\begin{array}{l}\text { Description and } \\
\text { findings re EC1 }\end{array}$ & 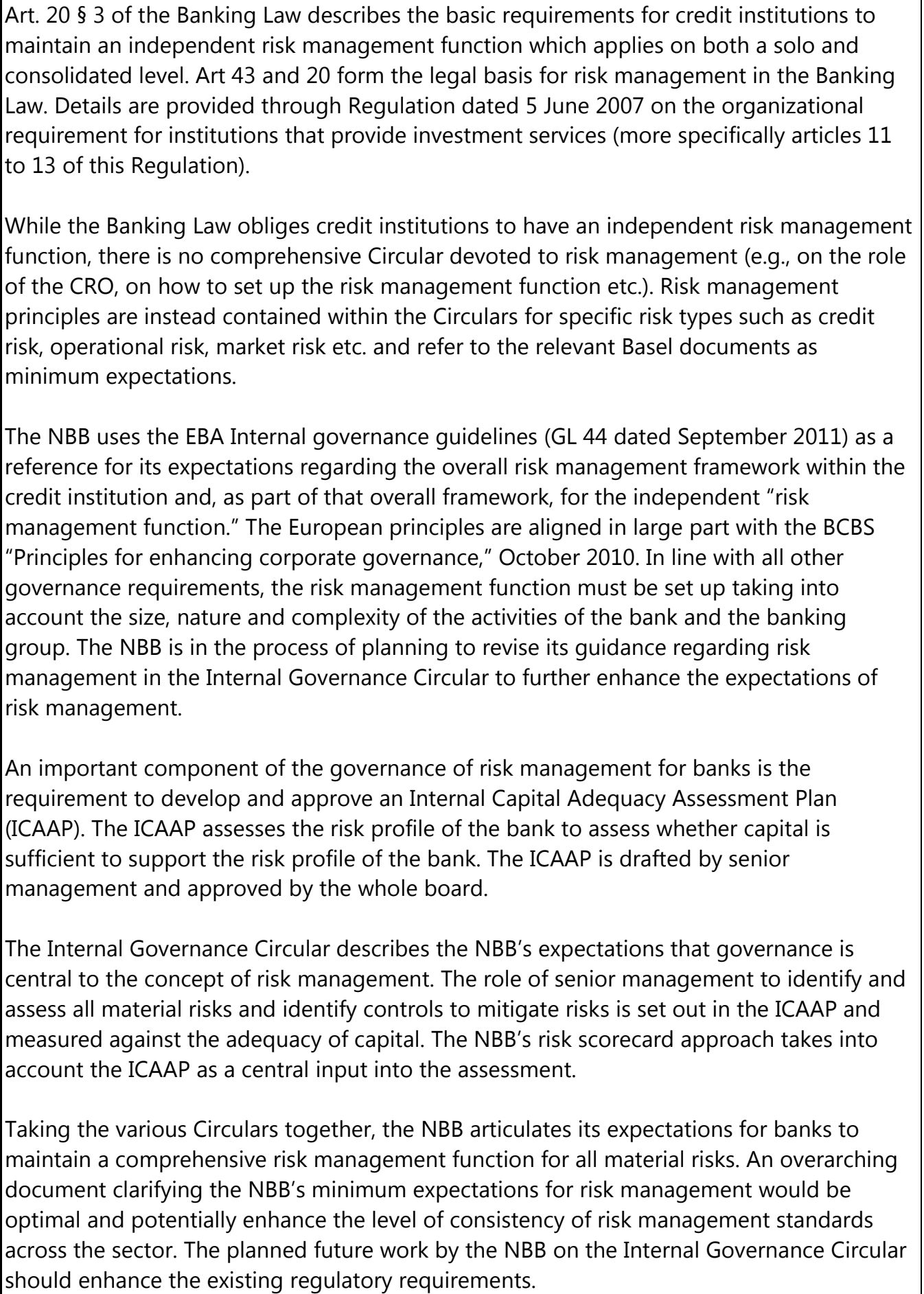 \\
\hline
\end{tabular}




\begin{tabular}{|c|c|}
\hline & 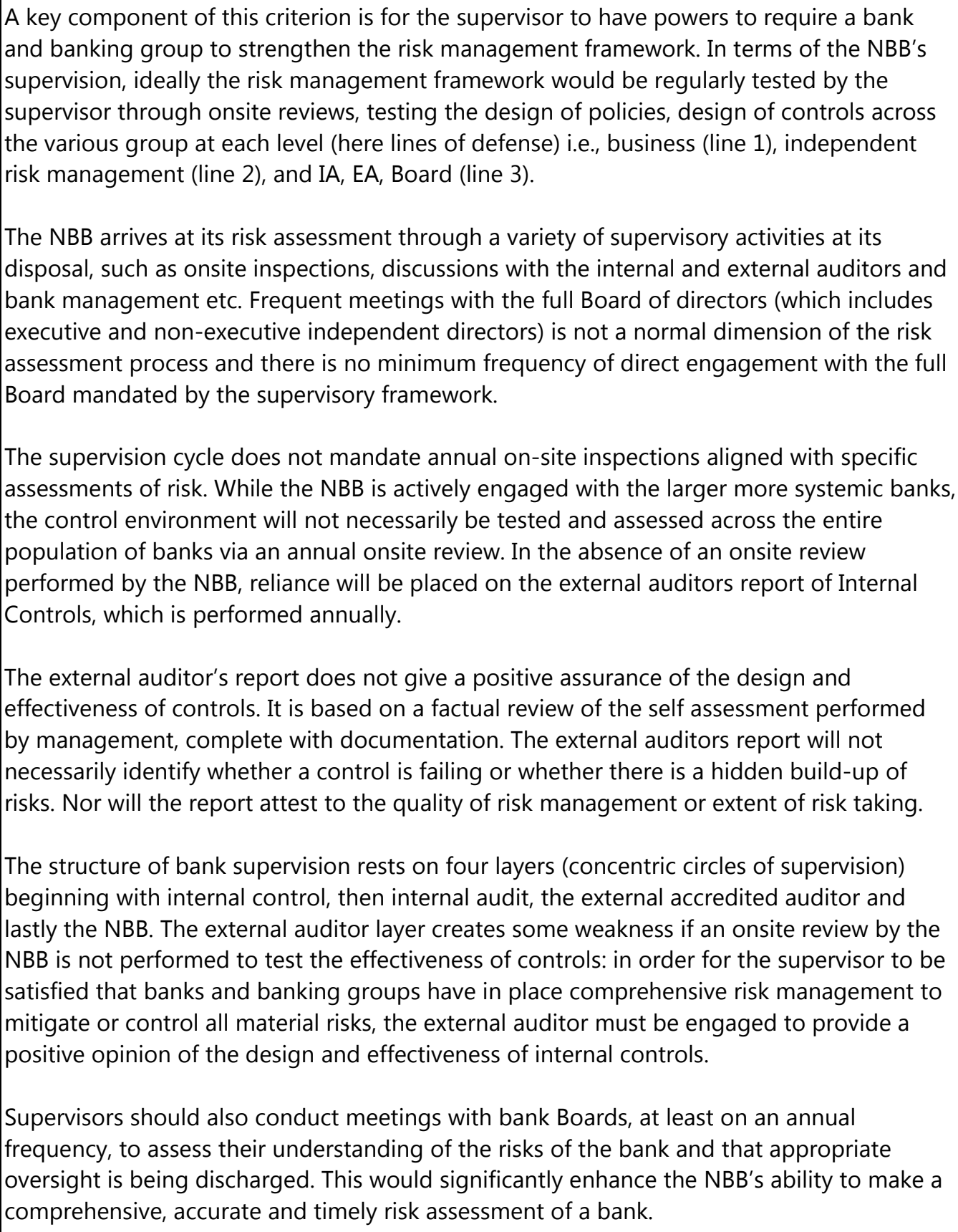 \\
\hline EC2 & $\begin{array}{l}\text { The supervisor confirms that banks and banking groups have appropriate risk management } \\
\text { strategies that have been approved by the board. The supervisor also confirms that the } \\
\text { board ensures that policies and processes for risk-taking are developed, appropriate limits } \\
\text { are established, and senior management takes steps necessary to monitor and control all } \\
\text { material risks consistent with the approved strategies. }\end{array}$ \\
\hline $\begin{array}{l}\text { Description and } \\
\text { findings re EC2 }\end{array}$ & $\begin{array}{l}\text { The Internal Governance Circular requires the Board of Directors to regularly assess and } \\
\text { approve the financial institution's general policy and strategy guidelines, which will include } \\
\text { risk management. }\end{array}$ \\
\hline
\end{tabular}




\begin{tabular}{|c|c|}
\hline & 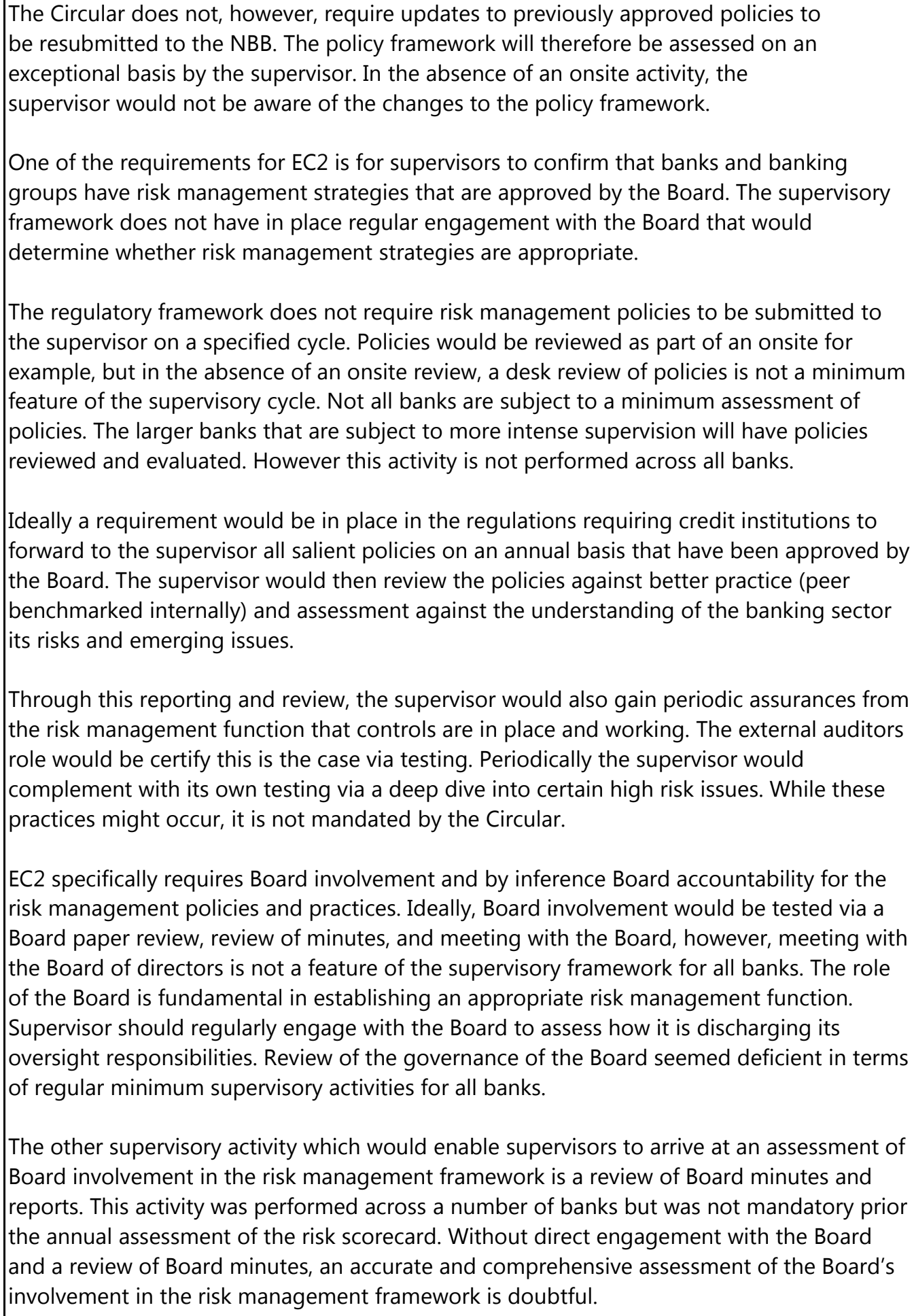 \\
\hline EC3 & $\begin{array}{l}\text { The supervisor determines that risk management strategies, policies, processes and limits } \\
\text { are properly documented, reviewed and updated, communicated within the bank and } \\
\text { banking group, and adhered to in practice. The supervisor determines that exceptions to } \\
\text { established policies, processes and limits receive the prompt attention of and authorization } \\
\text { by the appropriate level of management and the Board where necessary. }\end{array}$ \\
\hline
\end{tabular}




\begin{tabular}{|c|c|}
\hline $\begin{array}{l}\text { Description and } \\
\text { findings re EC3 }\end{array}$ & $\begin{array}{l}\text { NBB regulations require governance arrangements and risk management to be } \\
\text { documented, reviewed and updated through the governance memorandum of the bank. } \\
\text { However the regulations do not require policies to be submitted to the NBB when reviewed } \\
\text { or updated. The Board and senior management must approve the governance } \\
\text { memorandum. The memorandum will be adjusted each time a significant change that } \\
\text { impact the governance structure occurs. The NBB requires that this process take place at } \\
\text { least annually, which is adequate. } \\
\text { As discussed in EC1, the Internal Governance Circular articulates certain expectations of the } \\
\text { risk management function, however, it does not immediately follow that the supervisor will } \\
\text { perform a review of the policies and processes at a minimum frequency for all banks. } \\
\text { A critical aspect of EC3 is for supervisors to be satisfied that policies are communicated } \\
\text { within the banking group and adhered to in practice. Supervisory activity would need to } \\
\text { test or obtain assurances that the policies are adhered to. Exception reporting is an } \\
\text { important aspect of EC3. Supervisors endeavor to develop a level of comfort that policies } \\
\text { and processes are in place that identify, monitor and report to Board exceptions to policy. } \\
\text { One example of a useful of exception reporting for credit risk is loans approved outside of } \\
\text { policy or number of overrides (i.e., scorecards). Reporting such as exceptions to policy and } \\
\text { overrides helps to ensure Boards are kept aware of the degree to which policy is being } \\
\text { adhered to i.e., risk appetite can change through the application of the policy without the } \\
\text { policy changing. } \\
\text { The self assessment by management will describe and test the control environment and set } \\
\text { out remediation activities throughout the next year to address any deficiencies. External } \\
\text { audit will then perform a review of the self assessment. The results of the self assessment } \\
\text { and the external auditor's report will be submitted to the supervisor annually for all banks. } \\
\text { In the absence of any other triggers from the ICAAP, quarterly analysis etc, this report will } \\
\text { confirm the integrity of the control environment and risk management. }\end{array}$ \\
\hline EC4 & $\begin{array}{l}\text { The supervisor determines that senior management and the board understand the nature } \\
\text { and level of risk being taken by the bank and how this risk relates to adequate capital } \\
\text { levels. The supervisor also determines that senior management ensure that the risk } \\
\text { management policies and processes are appropriate in the light of the bank's risk profile } \\
\text { and business plan and that they are implemented effectively. This includes a requirement } \\
\text { that senior management regularly reviews and understand the implications (and } \\
\text { limitations) of the risk management information that it receives. The same requirement } \\
\text { applies to the board in relation to risk management information presented to it in a format } \\
\text { suitable for board oversight. }\end{array}$ \\
\hline $\begin{array}{l}\text { Description and } \\
\text { findings re EC4 }\end{array}$ & $\begin{array}{l}\text { One of the expectations of EC4 is that the supervisor arrives at an assessment of the } \\
\text { Board's understanding of the nature and level of risk being taken by the bank and how } \\
\text { this risk relates to adequate capital levels. Banks are required to prepare an ICAAP } \\
\text { annually which the NBB will use in its risk assessment. The ICAAP is a central feature of } \\
\text { the risk assessment process performed by the supervisor at least annually as an input } \\
\text { into the risk scorecard. However, as part of this process, an assessment of the Board's } \\
\text { involvement in the ICAAP is not necessarily performed across all banks. The ICAAP } \\
\text { document is reviewed, but the Board is not challenged as to its involvement. Without } \\
\text { regular contact with the Board, the assessment as to the Board's understanding of the } \\
\text { risk profile and adequacy of capital relies on a review of the ICAAP document rather than } \\
\text { the Board's understanding or extent of involvement in this process. }\end{array}$ \\
\hline
\end{tabular}




\begin{tabular}{|c|c|}
\hline & $\begin{array}{l}\text { Article XII.3 of NBB Regulation 15/11/2011 details the requirements associated with the } \\
\text { ICAAP. Paragraph } 9 \text { specifically states that "The credit institution shall be in a position to } \\
\text { provide complete information regarding its ICAAP to the NBB." While it is clear that the } \\
\text { regulations require banks to produce an ICAAP regularly, the regulations do not appear } \\
\text { to require the ICAAP to be submitted to the NBB, although this is an expectation of the } \\
\text { supervisors. } \\
\text { For the larger banks the engagement with senior management will be much more } \\
\text { frequent i.e., quarterly than for smaller banks. Engagement with the board however, is } \\
\text { less frequent and for independent non-executive directors it was not clear that direct } \\
\text { engagement was undertaken. }\end{array}$ \\
\hline EC5 & $\begin{array}{l}\text { The supervisor determines that the banks have an internal process for assessing their } \\
\text { overall capital adequacy in relation to their risk profile, and reviews and evaluates bank's } \\
\text { internal capital adequacy assessments and strategies. The nature of the specific } \\
\text { methodology used for this assessment will depend on the size, complexity and business } \\
\text { strategy of a bank. Non-complex banks may opt for a more qualitative approach to capital } \\
\text { planning. }\end{array}$ \\
\hline $\begin{array}{l}\text { Description and } \\
\text { findings re EC5 }\end{array}$ & $\begin{array}{l}\text { The basis for this criterion is outlined in the Banking Law Article } 43 \text { with a specific } \\
\text { requirement for capital risk management are contained in several Circulars, including: NBB } \\
\text { Regulation 15/11/2011, article XII.1.; Circular CBFA_2011_03 dated 27 January 2011, } \\
\text { comments to Title XII.; and Circular PPB-2007-15-CPB-CPA, } 18 \text { December 2007, related to } \\
\text { the prudential expectations on ICAAP. Lastly, CEBS guidelines on the Application of the } \\
\text { Supervisory Review Process under Pillar 2, January } 2006 \text {. } \\
\text { Banks are required to submit the ICAAP on at least an annual basis. The NBB assesses the } \\
\text { ICAAP as part of the SREP process for all banks on an annual basis. The ICAAP considers } \\
\text { the risk profile of the bank in relation to the nature of business, size and complexity of its } \\
\text { activities and considers whether capital is adequate. } \\
\text { The capital setting process takes into account the ICAAP and the risk score which is a } \\
\text { comprehensive assessment of the bank across all risk categories. While the ICAAP was } \\
\text { demonstrated to be integral to the supervisor's annual risk assessment of banks, it was not } \\
\text { clear how the supervisor became satisfied that the ICAAP was integrated into the risk } \\
\text { management and capital settings of the bank. While the ICAAP is required to be signed by } \\
\text { senior management and the Board, this does not by itself ensure that the process is } \\
\text { integrated into the risk management framework. To determine that the bank has an } \\
\text { internal process for assessing overall capital adequacy in relation to the risk profile the } \\
\text { supervisor would need to perform a number of activities which tests and evaluates the risk } \\
\text { management framework as well as the capital planning and forecasting process. }\end{array}$ \\
\hline EC6 & $\begin{array}{l}\text { Where banks and banking groups use models to measure components of risk, the } \\
\text { supervisor determines that banks perform periodic and independent validation and testing } \\
\text { of the models and systems. }\end{array}$ \\
\hline $\begin{array}{l}\text { Description and } \\
\text { findings re EC6 }\end{array}$ & $\begin{array}{l}\text { There is no minimum cycle for banks that are accredited to use internal models to } \\
\text { demonstrate to the NBB a proper and independent validation. When models are approved, } \\
\text { typically the NBB will apply conditions of approval. The terms and conditions will typically } \\
\text { include the requirement to submit data relating to performance and monitoring over a } \\
\text { defined period. The ongoing submission of data, however, is not mandated over the life of } \\
\text { the model. Nor will the terms and conditions necessarily require notification if model } \\
\text { validation is not completed as per plan or results fail to meet acceptable standards. }\end{array}$ \\
\hline
\end{tabular}




\begin{tabular}{|c|c|}
\hline & $\begin{array}{l}\text { Typically the NBB will perform a comprehensive review of a bank's suite of models via } \\
\text { alternative triggers such as a request to introduce a new model. The quantitative models } \\
\text { team regularly engages with the industry and will in practice engage with accredited banks } \\
\text { regularly. Nonetheless, there is no requirement for an internal model user to advise the } \\
\text { NBB if the model's discriminatory ability degrades below a certain level. }\end{array}$ \\
\hline \multicolumn{2}{|r|}{ 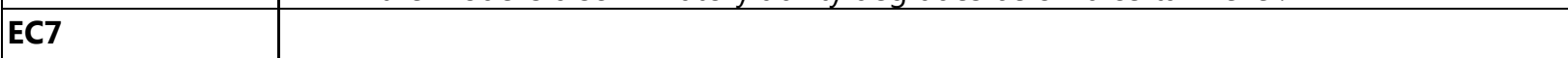 } \\
\hline $\begin{array}{l}\text { Description and } \\
\text { findings re EC7 }\end{array}$ & $\begin{array}{l}\text { Banking Law of } 22 \text { March 1993, Article } 20 \text { sets out the general requirements related to the } \\
\text { safe and sound organization and adequate internal control of credit institutions. NBB } \\
\text { Regulation 15/11/2011, article XII.3 related to the ICAAP. Circular PPB-2007-1-CPB, } 8 \\
\text { February 2007, updated } 27 \text { January 2011, comments to article XII.3. Circular NBB_2011_09 } \\
\text { dated } 20 \text { December } 2011 \text { on the governance of credit institutions. } \\
\\
\text { The bank's ICAAP is an important supervisory tool required of all banks to assess the risk } \\
\text { profile and capital adequacy on an annual basis. The NBB will perform an assessment on } \\
\text { the ICAAP to assess risks. }\end{array}$ \\
\hline EC8 & $\begin{array}{l}\text { The supervisor determines that banks have policies and processes in place to ensure that } \\
\text { new products and major risk management initiatives are approved by the board or a } \\
\text { specific committee of the board. }\end{array}$ \\
\hline $\begin{array}{l}\text { Description and } \\
\text { findings re EC8 }\end{array}$ & $\begin{array}{l}\text { NBB's Circular regarding Internal Governance develops a governance framework for } \\
\text { activities which might change the risk profile of the bank such as the introduction of } \\
\text { complex structures and/or offshore activities. The Circular states "Launching activities in } \\
\text { foreign jurisdictions and/or setting up or selling new complex structures should be subject } \\
\text { to a process of internal approval involving the compliance function and/or actuarial } \\
\text { function. Internal control on these activities is in proportion with their importance and the } \\
\text { associated risks." } \\
\text { In these circumstances, the independent control functions of the financial institution and } \\
\text { the statutory auditor should have unlimited access to the information and structures, as } \\
\text { required by their respective tasks. The auditor should be kept informed of any significant } \\
\text { development in the relevant activities. }\end{array}$ \\
\hline EC9 & $\begin{array}{l}\text { The supervisor determines that banks and banking groups have risk evaluation, monitoring } \\
\text { and control or mitigation functions with duties clearly segregated from risk-taking } \\
\text { functions in the bank, and which report on risk exposures directly to senior management } \\
\text { and the board. }\end{array}$ \\
\hline $\begin{array}{l}\text { Description and } \\
\text { findings re EC9 }\end{array}$ & $\begin{array}{l}\text { The relevant regulation is the Internal Controls Circular, which sets out certain minimum } \\
\text { expectations for the independent risk management function and the way it should be } \\
\text { organized. The RCF should be an institution's central organizational feature, structured so it } \\
\text { can implement risk policies and control the risk management framework. Large, complex } \\
\text { and sophisticated institutions may consider establishing dedicated RCFs for each material } \\
\text { business line. However, there should be in the institution a central RCF (including where } \\
\text { appropriate a Group RCF in the parent company of a group) to deliver a holistic view on all } \\
\text { the risks. } \\
\text { The NBB rules require the RCF to be independent of the business and support units whose } \\
\text { risks it controls but not be isolated from them. It should possess sufficient knowledge on } \\
\text { risk management techniques and procedures and on markets and products. Interaction } \\
\text { between the operational functions and the RCF should facilitate the objective that all the } \\
\text { institution's staff bears responsibility for managing risk. }\end{array}$ \\
\hline
\end{tabular}




\begin{tabular}{|c|c|}
\hline & $\begin{array}{l}\text { The Internal Governance Circular also contains some general principles regarding the } \\
\text { concept of "independent" control function. However, what is not specified in the } \\
\text { regulations is for the requirement that risk exposures are reported directly to senior } \\
\text { management and to the Board. The most clear example of this relates to the credit risk } \\
\text { framework, which does not require exposures over a certain percentage of own funds to } \\
\text { be approved by the Board. Equally, the Circular does not require exceptions to policy to be } \\
\text { reported to senior management or the Board. }\end{array}$ \\
\hline EC10 & $\begin{array}{l}\text { The supervisor issues standards related to, in particular, credit risk, market risk, liquidity risk, } \\
\text { interest rate risk in the banking book and operational risk. }\end{array}$ \\
\hline $\begin{array}{l}\text { Description and } \\
\text { findings re EC10 }\end{array}$ & $\begin{array}{l}\text { The supervisor has issued specific guidance in relation to credit, market, liquidity. Interest } \\
\text { rate risk and operational risk. In these cases the NBB has used explicit reference to the } \\
\text { relevant Basel documents to express its minimum expectations. }\end{array}$ \\
\hline \multicolumn{2}{|l|}{$\begin{array}{l}\text { Additional } \\
\text { criteria }\end{array}$} \\
\hline AC1 & $\begin{array}{l}\text { The supervisor requires larger and more complex banks to have a dedicated unit(s) } \\
\text { responsible for risk evaluation, monitoring and control or mitigation for material risk areas. } \\
\text { The supervisor confirms that this unit (these units) is (are) subject to periodic review by the } \\
\text { internal audit function. }\end{array}$ \\
\hline $\begin{array}{l}\text { Description and } \\
\text { findings re } A C 1\end{array}$ & $\begin{array}{l}\text { The expectations of the NBB in respect of systemic and larger banks to have dedicated risk } \\
\text { management units are established in the application of the proportionality rules which set } \\
\text { that higher standards for complex banks presenting higher risk appetites and risk profiles. }\end{array}$ \\
\hline AC2 & $\begin{array}{l}\text { The supervisor requires banks to conduct rigorous, forward-looking testing that identifies } \\
\text { possible events or changes in market conditions that could adversely impact on the bank. }\end{array}$ \\
\hline $\begin{array}{l}\text { Description and } \\
\text { findings re } A C 2\end{array}$ & $\begin{array}{l}\text { NBB expects institutions to develop, in the course of their ICAAP, rigorous capital planning } \\
\text { and stress testing exercises. } \\
\text { NBB expects institutions to develop a sound, comprehensive and rigorous stress testing } \\
\text { framework that should encompass all the material risks (both on- and off balance sheet) } \\
\text { relevant for the banking group and should be based on a "building block" approach. } \\
\text { Such approach will require adequate and sound stress testing governance structures } \\
\text { implying actual, reviewed and efficient use of the stress tests programs and results; the use } \\
\text { of a range of methodologies undertaking both simple sensitivity analyses and more } \\
\text { complex scenario stress testing with a range of severity; a multi-layered approach to stress } \\
\text { testing programmes, from simple portfolio-level to comprehensive firm-wide scenario } \\
\text { analyses; actual and adequate interactions/implications between the outcomes of stress } \\
\text { tests and management intervention/mitigating actions; and finally, the use of rigorous } \\
\text { stress tests to assess the viability of the institution's capital plan in adverse circumstances in } \\
\text { the context of ICAAP. To develop adequate stress testing framework institutions must } \\
\text { follow the } 17 \text { principles included in the CEBS's Guidelines on stress testing. }\end{array}$ \\
\hline AC3 & $\begin{array}{l}\text { The supervisor requires banks and banking groups to have in place appropriate policies } \\
\text { and processes for assessing other material risks not directly addressed in the subsequent } \\
\text { CPs, such as reputational and strategic risks. }\end{array}$ \\
\hline $\begin{array}{l}\text { Description and } \\
\text { findings re AC3 }\end{array}$ & $\begin{array}{l}\text { NBB expects institutions to take account of all material risks, including business, strategic } \\
\text { and reputation risks, in the course of their ICAAP exercise. If not satisfied with the scope } \\
\text { defined by institutions, NBB is empowered to take the necessary remedial actions, } \\
\text { including the definition of additional capital requirements. }\end{array}$ \\
\hline
\end{tabular}




\begin{tabular}{|c|c|}
\hline $\begin{array}{l}\text { Assessment of } \\
\text { Principle } 7\end{array}$ & Largely Compliant \\
\hline Comments & $\begin{array}{l}\text { Many of the criteria in CP7 require the supervisor to assess the Board's involvement in the } \\
\text { risk management function. Indeed, the Principle focuses on Board oversight of risk } \\
\text { management policies and processes. While the regulations require Boards to approve risk } \\
\text { management strategies and the ICAAP, the supervisory assessment of the Board's } \\
\text { involvement and understanding of risks and risk management will not necessarily involve } \\
\text { direct engagement with the Board (independent non-executive directors), even for larger } \\
\text { systemic banks on at least an annual frequency. Without direct engagement with the Board } \\
\text { to challenge their appreciation of the risks, the implementation of risk management and } \\
\text { adequacy of capital, it is difficult to see how the supervisor is able to arrive at an accurate, } \\
\text { timely and comprehensive view of the Board's oversight of risk management. } \\
\text { Annual meetings will the Board would assist the supervisor to make accurate, timely and } \\
\text { comprehensive assessments of the Boards' involvement in the risk management framework } \\
\text { as an input in the annual risk assessment process. } \\
\text { The documentation requirements for the internal governance memorandum, the ICAAP } \\
\text { reporting and the internal control statement could be made more explicit/ better aligned } \\
\text { to ensure that all material Board approved policies are submitted to the NBB on at least an } \\
\text { annual basis. } \\
\text { The Internal Governance Circular should require notification to the NBB if an accredited } \\
\text { model fails annual validation with a remediation plan. }\end{array}$ \\
\hline Principle 8 & $\begin{array}{l}\text { Credit risk. Supervisors must be satisfied that banks have a credit risk management } \\
\text { process that takes into account the risk profile of the institution, with prudent policies and } \\
\text { processes to identify, measure, monitor and control credit risk (including counterparty risk). } \\
\text { This would include the granting of loans and making of investments, the evaluation of the } \\
\text { quality of such loans and investments, and the ongoing management of the loan and } \\
\text { investment portfolios. }\end{array}$ \\
\hline \multicolumn{2}{|l|}{ Essential criteria } \\
\hline EC1 & $\begin{array}{l}\text { The supervisor determines, and periodically confirms, that a bank's Board approves, and } \\
\text { periodically reviews, the credit risk management strategy and significant policies and } \\
\text { processes for assuming, identifying, measuring, controlling and reporting on credit risk } \\
\text { (including counterparty risk). The supervisor also determines, and periodically confirms, } \\
\text { that senior management implements the credit risk strategy approved by the Board and } \\
\text { develops the aforementioned policies and processes. }\end{array}$ \\
\hline $\begin{array}{l}\text { Description and } \\
\text { findings re } E C 1\end{array}$ & $\begin{array}{l}\text { The Banking Law does not make specific reference to credit risk management. The Banking } \\
\text { Law does, however, refer more generally to risk management (Art 20). The NBB issued a } \\
\text { Circular NBB_2011_09 of } 20 \text { December } 2011 \text { on internal control which references the Basel } \\
\text { Document "Principles of Credit Risk Management" of } 2000 \text { as a standard for banks in } \\
\text { assessing the adequate organization of their credit risk functions. } \\
\text { To satisfy the requirements described in this criterion the NBB relies upon the Basel } \\
\text { principles. The NBB will assess compliance with the principles through three main activities: } \\
\text { 1. On site examinations. Onsite inspections will assess all aspects of the credit } \\
\text { risk process, as set out in the inspection manual. Aside from inspections relating to } \\
\text { credit risk activities, onsite inspections validate internal model on credit risk focus, }\end{array}$ \\
\hline
\end{tabular}




\begin{tabular}{|c|c|}
\hline & $\begin{array}{l}\text { not only on the statistical methodology, but also on the quality of the credit risk } \\
\text { management and organization. } \\
\text { 2. Report of the management on internal control; The Circular letter } \\
\text { NBB_2011_09 of } 20 \text { December } 2011 \text { on internal control requires the bank } \\
\text { management to assess the internal control, including with regard to the credit } \\
\text { activities, and report the conclusions to the NBB. } \\
\text { 3. Reports of accredited auditors: accredited auditors are required, as part of } \\
\text { their duties, to maintain a permanent information file with the NBB giving a } \\
\quad \text { banks with which they have mandate. Credit risk is a key focus of these files. The } \\
\text { supervisors regularly assess the quality of these files. } \\
\text { The result of the assessment is summarized in the scorecard relating to credit risk. The } \\
\text { offsite analysis based on quarterly data submitted by all banks on a solo and consolidated } \\
\text { basis forms the foundation for credit risk assessment by the supervisor. } \\
\text { There was evidence of detailed horizontal analysis, which had been performed on specific } \\
\text { thematic issues such as mortgage portfolios, sovereign credit risk etc. The analysis was of } \\
\text { high quality. } \\
\text { If an onsite review is warranted, inspections will assess all aspects of the credit risk } \\
\text { management process. For banks accredited to use internal models, a separate Circular } \\
\text { applies to the bank and a more extensive onsite assessment will be involved. } \\
\text { The Circular for credit risk does not require credit risk policies to be submitted to NBB } \\
\text { when reviewed and approved by the board or in the event that material changes are made } \\
\text { such as in the instance of limits and delegations. Changes in policy often flag a change in } \\
\text { underwriting approach and potentially a change in risk appetite. The NBB does, however, } \\
\text { mane other mechanisms by which it can detect material changes in policies. } \\
\text { in the NBB's Circular on credit risk. Overall, the regulatory framework appears consistent } \\
\text { with this criterion. }\end{array}$ \\
\hline EC2 & $\begin{array}{l}\text { The supervisor requires, and periodically confirms, that such policies and processes } \\
\text { establish an appropriate and properly controlled credit risk environment, including: } \\
\text { - a well documented strategy and sound policies and processes for assuming credit } \\
\text { risk; } \\
\text { well defined criteria and policies and processes for approving new exposures as } \\
\text { well as renewing and refinancing existing exposures, identifying the appropriate }\end{array}$ \\
\hline
\end{tabular}




\begin{tabular}{|c|c|}
\hline & $\begin{array}{l}\text { approval authority for the size and complexity of the exposures; } \\
\text { effective credit administration policies and processes, including continued analysis } \\
\text { of a borrower's ability and willingness to repay under the terms of the debt, } \\
\text { monitoring of documentation, legal covenants, contractual requirements and } \\
\text { collateral, and a classification system that is consistent with the nature, size and } \\
\text { complexity of the bank's activities or, at the least, with the asset grading system } \\
\text { prescribed by the supervisor; } \\
\text { comprehensive policies and processes for reporting exposures on an ongoing } \\
\text { basis; } \\
\text { comprehensive policies and processes for identifying problem assets; and } \\
\text { prudent lending controls and limits, including policies and processes for } \\
\text { monitoring exposures in relation to limits, approvals and exceptions to limits. }\end{array}$ \\
\hline & $\begin{array}{l}\text { This criterion expects the supervisor to perform two types of activities: the first is a regular } \\
\text { review of policies. This activity will cover the requirements for banks to have credit risk } \\
\text { management strategies, sound policies that cover all aspects of credit risk including } \\
\text { problem assets. The regulations, which are based on the Basel principles, do not require } \\
\text { banks to submit policies on a minimum cycle i.e., annually. Policies will be reviewed as part } \\
\text { of an onsite review or if triggered by an exception. Policies will also be reviewed by Internal } \\
\text { Audit. } \\
\text { Policies might also be reviewed through other supervisory activities such as horizontal } \\
\text { analysis, however it is not mandated that the supervisor would review and assess credit risk } \\
\text { policies and strategies prior to updating the scorecard. For the larger systemic banks, the } \\
\text { NBB will be in constant contact with many sources of qualitative and quantitative } \\
\text { information pertaining to credit risk. } \\
\text { The second aspect of this criterion is for the supervisor to confirm that practices align with } \\
\text { policy and are prudent. In practice, the minimum supervision cycle for onsite reviews will } \\
\text { depend upon the result of the risk scorecard. While the criterion does not prescribe a } \\
\text { specific timeframe, scorecards are updated on an annual cycle. For the larger systemic } \\
\text { banks it was evidenced that annual reviews are performed that comprehensively cover this } \\
\text { criterion. However, for the broader population of banks, the frequency of supervisory } \\
\text { activities to assess whether credit practices aligned with policies was not mandated. }\end{array}$ \\
\hline EC3 & $\begin{array}{l}\text { The supervisor requires, and periodically confirms, that banks make credit decisions free of } \\
\text { conflicts of interest and on an arm's length basis. }\end{array}$ \\
\hline $\begin{array}{l}\text { Description and } \\
\text { findings re EC3 }\end{array}$ & $\begin{array}{l}\text { This criterion requires that credit risk decisions are free of conflicts of interest and credit } \\
\text { decisions are made on an arms' length basis. EC3 expects banks to have a policy framework } \\
\text { that covers credit decisions across the organization. The supervisor should ensure policies } \\
\text { are implemented and controls are in place that confirm policies are designed appropriately, } \\
\text { implemented effectively, working as needed and no incidence of conflict. Article } 28 \text { of the } \\
\text { Banking Law states that credit to a member of the Board or senior management shall be } \\
\text { granted at arm's length (under the same considerations as credit to other customers). } \\
\text { The NBB will obtain confirmation of compliance with the various regulations from a variety } \\
\text { of sources: internal control report, external auditor, internal audit. Article } 523 \text { of the } \\
\text { Company Law prohibits a member of the Board from participating in a decision when that } \\
\text { member has a potential conflict of interest. This applies for credit applications from a } \\
\text { shareholder or a Board member. } \\
\text { Under the own funds regulation (see title II of own funds regulations), even if the credit is } \\
\text { granted on arm's length basis, the credit amount will be deduced from own funds if the }\end{array}$ \\
\hline
\end{tabular}




\begin{tabular}{|c|c|}
\hline & $\begin{array}{l}\text { credit has been use to increase the own funds of the institution or if there's some doubt } \\
\text { about the ability of the shareholder to redeem the credit. } \\
\text { Pursuant to Article } 28 \text { of the Banking Law of } 22 \text { March } 1993 \text {, a credit extended to a member } \\
\text { of the board or senior management shall be granted at arm's length condition (same } \\
\text { condition as credit granted to the customers). } \\
\text { The weakness in the credit risk framework is in relation to the granting of credit to major } \\
\text { shareholders to purchase own shares that would increase the own funds of the bank. These } \\
\text { decisions are not subject to any particular oversight framework and with only guidance that } \\
\text { they should be made under similar conditions to other customers. In practice, it would be } \\
\text { difficult for the bank, or an officer of the bank, to refuse credit especially in an instance } \\
\text { where the bank needed to raise capital. Furthermore, there is no requirement in the } \\
\text { regulations for major credit risk exposures over a certain amount (or percentage of the } \\
\text { bank's own funds), to be decided by the bank's senior management or Board. In effect, } \\
\text { critical credit decisions could potentially be made by officers of the bank that are under the } \\
\text { direction of senior management. } \\
\text { This issue has clearly been problematic for the Belgium financial sector in the recent past. } \\
\text { We see evidence that the NBB has taken sound measures to account for situations where } \\
\text { the bank grants credit to a major shareholder (or to the member of the Board) to increase } \\
\text { own funds by deducting the amount from own funds calculation in Pillar } 2 \text {. Nonetheless, } \\
\text { the lack of a clear prohibition in the regulation leaves open the potential for conflicts of } \\
\text { interest to occur in the future. }\end{array}$ \\
\hline EC4 & $\begin{array}{l}\text { The supervisor has full access to information in the credit and investment portfolios and to } \\
\text { the bank officers involved in assuming, managing, controlling and reporting on credit risk. }\end{array}$ \\
\hline $\begin{array}{l}\text { Description and } \\
\text { findings re EC4 }\end{array}$ & $\begin{array}{l}\text { NBB has full access to all information of a credit nature as per Article } 46 \text { of the Banking Law } \\
\text { that states "NBB may, for the purpose of the prudential supervision do the following: } \\
\text { 1. Require all information relating to the organization, the function, the situation and the } \\
\text { operations of a credit institution; } \\
\text { 2. Carry out onsite examination; } \\
\text { 3. Have access to all documents and information. }\end{array}$ \\
\hline \multicolumn{2}{|l|}{$\begin{array}{l}\text { Additional } \\
\text { criteria }\end{array}$} \\
\hline $\mathrm{ACl}$ & $\begin{array}{l}\text { The supervisor requires that the credit policy prescribes that major credit risk exposures } \\
\text { exceeding a certain amount or percentage of the bank's capital are to be decided by the } \\
\text { bank's senior management. The same applies to credit risk exposures that are especially } \\
\text { risky or otherwise not in line with the mainstream of the bank's activities. }\end{array}$ \\
\hline $\begin{array}{l}\text { Description and } \\
\text { findings re } A C 1\end{array}$ & $\begin{array}{l}\text { There is no specific provision in the law/regulation, which requires a bank to have an } \\
\text { approval by the senior management if a credit exposure exceeds a certain amount or risk. } \\
\text { Each bank is required to define the credit policy including the delegation of powers with } \\
\text { regard to credit granting, which should take into account the size and the risk of credit } \\
\text { exposures. }\end{array}$ \\
\hline
\end{tabular}




\begin{tabular}{|c|c|}
\hline & $\begin{array}{l}\text { So while credit institutions are required to define their credit risk policy, there is no } \\
\text { mandatory delegation hierarchy where loans over a certain amount or percentage of own } \\
\text { funds would only be approved by senior management or the Board. }\end{array}$ \\
\hline AC2 & $\begin{array}{l}\text { The supervisor determines that banks have in place policies and processes to identify, } \\
\text { measure, monitor and control counterparty credit risk exposure, including potential future } \\
\text { exposure sufficient to capture the material risks inherent in individual products or } \\
\text { transactions. These processes should be commensurate with the size or complexity of the } \\
\text { individual bank. }\end{array}$ \\
\hline $\begin{array}{l}\text { Description and } \\
\text { findings re } A C 2\end{array}$ & $\begin{array}{l}\text { These requirements are part of the Basel principles, which is the standard used by the NBB. } \\
\text { Assessments of compliance with these requirements are made through on-site inspections, } \\
\text { report of the bank management on internal control and reports of the accredited auditors. }\end{array}$ \\
\hline AC3 & $\begin{array}{l}\text { The supervisor determines that banks have policies and processes to monitor the total } \\
\text { indebtedness of entities to which they extend credit. }\end{array}$ \\
\hline $\begin{array}{l}\text { Description and } \\
\text { findings re } A C 3\end{array}$ & $\begin{array}{l}\text { This requirement is covered adequately by the NBB's existing regulations, which rely upon } \\
\text { the Basel principles. Compliance with these requirements is assessed through on-site } \\
\text { inspections, report of the bank management on internal control and reports of the } \\
\text { Accredited auditors. } \\
\text { The result of the assessment is summarized in the scorecard relating to credit risk. The NBB } \\
\text { sets minimum requirements obliging the bank to monitor the credit quality of the entities } \\
\text { to which they extend credit and so on, to review the internal rating of the counterparty is a } \\
\text { minimum requirements as part of its authorization of a bank to use an internal model for } \\
\text { credit risk to calculate the minimum solvency requirements. Compliance with this } \\
\text { requirement is assessed also during the validation process of IRB Models. }\end{array}$ \\
\hline $\begin{array}{l}\text { Assessment of } \\
\text { Principle } 8\end{array}$ & Largely Compliant \\
\hline Comments & $\begin{array}{l}\text { There is no requirement in the regulations for major credit risk exposures over a certain } \\
\text { amount or percentage of the bank's own funds, to be decided by the bank's senior } \\
\text { management or board. } \\
\text { Without this requirement, critical credit decisions can in practical terms be made by officers } \\
\text { of the bank who might not be suitably informed of all risks. An effective delegation } \\
\text { structure will strengthen the risk management framework to ensure that credit decisions } \\
\text { are only taken at an appropriate level. This will also help to avoid unnecessary conflicts of } \\
\text { interest, which might arise in relation to the granting of credit. While a conflicts of interest } \\
\text { policy is required by the regulations, it might prove inadequate at fully mitigating this risk. }\end{array}$ \\
\hline Principle 9 & $\begin{array}{l}\text { Supervisors must be satisfied that banks establish and adhere to adequate policies and } \\
\text { processes for managing problem assets and evaluating the adequacy of provisions and } \\
\text { reserves. }\end{array}$ \\
\hline \multicolumn{2}{|l|}{ Essential criteria } \\
\hline EC1 & $\begin{array}{l}\text { Laws, regulations or the supervisor require banks to formulate specific policies and } \\
\text { processes for identifying and managing problem assets. In addition, laws, regulations or } \\
\text { the supervisor require periodic review by banks of their problem assets (at an individual } \\
\text { level or at a portfolio level for credits with homogenous characteristics) and asset } \\
\text { classification, provisioning and write-offs. }\end{array}$ \\
\hline
\end{tabular}


Description and findings re EC1
The regulatory framework governing problem assets, provisions and reserves consists of two layers. First, the accounting framework contains requirements governing the valuation and presentation of assets and liabilities in both general purpose financial statements and in prudential returns. Second, prudential regulation contains additional provisions on the management of credit risk and the solvency treatment of problem assets, provisions and reserves.

Accounting standards govern the preparation and presentation of general purpose, publicly disclosed financial statements by banks. The prudential framework refers to the standards in the accounting law and makes them applicable to the preparation and presentation of the prudential information that banks must report on a regular basis to the NBB for solvency purposes. As such, the capital adequacy requirements (in particular for credit risk) are predicated on the values attributed to loans in the accounts of the banks and therefore depends on the accounting classification and provisioning as applied to the loans pursuant to the accounting standards.

The accounting framework in Belgium consists of two regimes, BGAAP for banks prepared on a solo basis and IFRS for consolidated accounts.

The RD covering BGAAP articulates a general standard and definition for banks to identify impaired loans, distinguishing two degrees of problem assets: "loans with uncertain outcome" and "doubtful loans" (article 35 of the RD). Further distinctions are made depending on the nature of the problems (commercial credit risk and country-related risk). This RD implements the European Directive 86/635/EEC of 8 December 1986 on the annual accounts and consolidated accounts of banks and other financial institutions.

A loan classified as doubtful will require an individual (specific) provision in the expectation that full payment of the outstanding principal and interest will not be paid. A loan classified as uncertain will be assigned a general provision for the part that is uncertain. Under the "uncertain outcome" category - as this category is defined in a principle-based way "t there are in practice different subcategories used by banks for internal monitoring and assessment, such as: uncertain still performing; uncertain but 90 days past due; doubtful but recourse guaranteed; or incurred but not reported. It is noted that for prudential purposes (art. VI.87 of the NBB regulation on own fund of 15/11/2011), an exposure is "defaulted" when past-due for more than 90 daysand/or it is probable that the debtor will not meet all its commitment (except under special measures such as resorting to guarantees). An exposure that is classified as "uncertain" or "doubtful" in the BGAAP financial statements shall be considered as "defaulted" for prudential purposes (see comments on article VI.87 in the circular letter).

Pursuant to Royal Decree of 23 September 1992, the consolidated accounts of credit institution must be prepared in accordance with IFRS. The application of IFRS at consolidated level is, for banks and investment firms, mandatory since 2006. Under IFRS, identification and treatment of problem assets, provision and reserves is governed by IAS39 (Financial Instruments: recognition and measurement) and, for assets other than financial instruments, IAS36 (Impairment of assets).

Review of loan classification is one of the central tasks performed by the external auditor, as part of the financial audit which is performed half yearly and annually-the annual audit consisting of a positive assurance. 


\begin{tabular}{|c|c|}
\hline & $\begin{array}{l}\text { All banks have to report provisioning data as part of the quarterly prudential returns } \\
\text { requirements (Schema A, tables } 50.10 \text { to 50.15). Detail has to be provided for the gross } \\
\text { outstanding amounts, available credit lines and guarantees and collateral. } \\
\text { The credit risk management framework requires banks to maintain adequate policies and } \\
\text { processes for the oversight and collection of past due or otherwise doubtful loans. In } \\
\text { practice banks have to determine policies and procedures regarding provisions and write- } \\
\text { offs separately for loans "with uncertain outcome" and for those with "high probability of } \\
\text { incomplete recovery." The assessment of the appropriateness of such policies is part of the } \\
\text { accredited external auditor. } \\
\text { The NBB is empowered to require institutions to: } \\
\quad \text { - Strengthen their credit policies and procedures; } \\
\quad \text { Provide for additional provisioning if the level thereof is deemed unsatisfactory; if } \\
\text { such requirement is not respected, the NBB may impose a capital add on under } \\
\text { the Pillar } 2 \text { process or a deduction from regulatory own funds for the calculation of } \\
\text { the solvency ratio. } \\
\text { The accounting provides the basis for banks to formulate policies and processes for } \\
\text { problem assets. The governance regulations require policies to be reviewed on an annual } \\
\text { basis. }\end{array}$ \\
\hline $\mathrm{EC2}$ & $\begin{array}{l}\text { The supervisor confirms the adequacy of the classification and provisioning policies and } \\
\text { processes of a bank and their implementation; the reviews supporting this opinion may be } \\
\text { conducted by external experts. }\end{array}$ \\
\hline $\begin{array}{l}\text { Description and } \\
\text { findings re EC2 }\end{array}$ & $\begin{array}{l}\text { The external auditor is charged with confirming the adequacy of the classification of } \\
\text { provisioning policies and processes, unless an onsite review is performed or other } \\
\text { exceptional circumstances. } \\
\text { The auditor performs a financial audit and will test whether provisioning aligns with the } \\
\text { definitions in the accounting standards. Review of loan classifications is one of the central } \\
\text { tasks entrusted to the external auditor of banks, who has to give an opinion on the } \\
\text { correctness of loan classification and provisioning in terms of the financial audit on an } \\
\text { annual basis. A limited review will be performed semi-annually. The auditor also confirms } \\
\text { the reliability of prudential returns. The external auditor is specially accredited by the NBB. } \\
\text { Under BGAAP, article } 27 \text { bis of the RD of } 23 \text { November } 1992 \text { specifies the methodology to } \\
\text { be used for recognizing interest on some specific assets (e.g., zero coupon bonds, } \\
\text { perpetual or loans with fixed constant payments). Interest on financial assets that are part } \\
\text { of the banking book is recognized on the basis of the effective interest rate methodology } \\
\text { (article 35ter, \$4 of the RD). Otherwise, accrued but not collected interest can be } \\
\text { recognized in P\&L and interest is normally not added to principal. } \\
\text { As mentioned above, BGAAP distinguishes two degrees of problem assets: "loans with } \\
\text { uncertain outcome" and "doubtful loans" (article } 35 \text { of the RD). Further distinctions are } \\
\text { made depending on the nature of the problems (commercial credit risk and country- } \\
\text { related risk). } \\
\text { At consolidated level (where IFRS apply), IFRS7 (Financial Instruments: Disclosures) requires } \\
\text { entities to disclose additional information on their financial assets that are either past due }\end{array}$ \\
\hline
\end{tabular}




\begin{tabular}{|c|c|}
\hline & $\begin{array}{l}\text { or impaired (IFRS7, paragraph 37). Based on this disclosure requirement, the prudential } \\
\text { financial reporting FINREP requires credit institutions to report detailed information on } \\
\text { their past due assets (template } 10 \text { of FINREP) to the NBB.). } \\
\text { Under the prudential framework, defaulted loans receive a specific treatment (notably a } \\
\text { higher risk weight in the standardized approach and a probability of default of } 100 \text { percent } \\
\text { in the IRB model approach). Defaulted loans include "non performing loan (= past due } \\
\text { loans from more } 90 \text { days), loans that have been restructured with a loss for the bank, and } \\
\text { loans that are likely to default in the near future. } \\
\text { As both BGAAP and IFRS are principle-based accounting standards, they do not require the } \\
\text { recognition of minimum amounts of provisions. } \\
\text { The classification of loans and valuation practices and the controls that are around these } \\
\text { two practices have a material impact on the level and adequacy of provisioning. Both of } \\
\text { these practices are principally confirmed by the external auditor. The extent of analysis by } \\
\text { the NBB in these two areas is not established within the supervisory framework on a } \\
\text { minimum supervision cycle. Clearly when performing an onsite review the classification of } \\
\text { loans will be included in the inspection. However the cycle for an onsite credit review for all } \\
\text { banks is not explicitly tied to a risk score or minimum cycle. } \\
\text { For the larger systemic banks, more scrutiny is in practice paid to this process, and receives } \\
\text { greater attention from onsite credit risks visits, periodic contact with the external auditor, } \\
\text { onsite reviews of controls and meetings with senior compliance officers and independent } \\
\text { risk management. }\end{array}$ \\
\hline EC3 & $\begin{array}{l}\text { The system for classification and provisioning takes into account off-balance sheet } \\
\text { exposures. }\end{array}$ \\
\hline & $\begin{array}{l}\text { At solo level, Article } 35, \S 1 \text { of the RD of } 23 \text { September } 1992 \text { requires banks to monitor, and } \\
\text { when necessary provision off-balance sheet exposures. Pursuant to this provision, account } \\
\text { must be taken of the risk that the counterparty does not meet its contractual commitments. } \\
\text { Article } 35 \text { allows banks to determine the impairment amount item by item or at portfolio } \\
\text { level (based on statistical information collected by the bank and taking account of the } \\
\text { economic conditions and the bank's policy in respect of such items). Article } 35 \text { also } \\
\text { specifies the classification applicable to off balance sheet items depending on whether the } \\
\text { risk attached thereto is "doubtful" or "with uncertain outcome." Further distinctions are } \\
\text { made depending on the nature of the problems (commercial credit risk and country- } \\
\text { related risk). } \\
\text { At consolidated level, under IFRS most if not all exposures will be reflected on balance } \\
\text { sheet. Either as a specific asset (financial instrument, insurance contract, lease contract...) } \\
\text { and, in this respect, will be subject to the impairment requirements applicable for that class } \\
\text { of asset, or as a provision pursuant to IAS37 (Provisions, Contingent Liabilities and } \\
\text { Contingent Assets). IAS37 requires entities to recognize a provision when it has present } \\
\text { obligation, which meets the condition of IAS37.14 (past event, probable outflow of } \\
\text { resources embodying economic benefits and reliable estimate of the obligation). Pursuant }\end{array}$ \\
\hline
\end{tabular}




\begin{tabular}{|c|c|}
\hline & $\begin{array}{l}\text { to IAS37.27 and seq. only contingent liabilities and contingent assets are not recognized on } \\
\text { the balance sheet; these are disclosed in the notes to the accounts. }\end{array}$ \\
\hline EC4 & $\begin{array}{l}\text { The supervisor determines that banks have appropriate policies and processes to ensure } \\
\text { that provisions and write-offs reflect realistic repayment and recovery expectations. }\end{array}$ \\
\hline $\begin{array}{l}\text { Description and } \\
\text { findings re EC } 4\end{array}$ & $\begin{array}{l}\text { Compliance with the accounting frameworks (BGAAP or IFRS) requires banks to have } \\
\text { appropriate policies and processes to ensure that provisions and write-offs reflect realistic } \\
\text { repayment and recovery expectations. } \\
\text { In terms of the BGAAP (solo) requirements, valuations, depreciations, write-offs and } \\
\text { provisions must meet the criteria of prudence, sincerity and good faith. They must be } \\
\text { accounted for systematically on the basis of methodologies adopted by the credit } \\
\text { institution. Exposures must account for all foreseeable risk, possible losses and } \\
\text { depreciations, which find their origin in past events that occurred before the balance-sheet } \\
\text { date (or after). } \\
\text { Article } 35 \text { of the RD of September } 1992 \text { requires credit institutions to apply a forward } \\
\text { looking approach in this respect and to reflect realistic repayment and recovery } \\
\text { expectations. } \\
\text { The impact of collateral is not defined under BGAAP (solo accounts). It generally accepted } \\
\text { that collateral is taken into account only when determining the level of provision. } \\
\text { For prudential purposes, further quantitative requirements apply on the treatment of } \\
\text { collateral pursuant to the chapter V of the NBB Regulation of } 15 / 11 / 2011 \text { on "own funds." } \\
\text { In accordance with article V18, banks can take into the account the value of collaterals } \\
\text { when determining the weighted volume of risk to which they are exposed (compensation } \\
\text { into the classification is possible in limited cases as set out in article V.21). Section IVIV of } \\
\text { Chapter V describes the methodologies to be used for the impact of the risk reducing } \\
\text { effect of collaterals. For instance, financial instruments are at fair value, corrected for } \\
\text { volatility (V.55 and V.58). }\end{array}$ \\
\hline EC5 & $\begin{array}{l}\text { The supervisor determines that banks have appropriate policies and processes, and } \\
\text { organizational resources for the early identification of deteriorating assets, for ongoing } \\
\text { oversight of problem assets, and for collecting on past due obligations. }\end{array}$ \\
\hline $\begin{array}{l}\text { Description and } \\
\text { findings re EC5 }\end{array}$ & $\begin{array}{l}\text { Compliance with accounting standards requires implicitly that banks have appropriate } \\
\text { policies and processes, and organizational resources for the early identification of } \\
\text { deteriorating assets, for ongoing oversight of problem assets, and for collecting on past } \\
\text { due obligations. } \\
\text { The credit portfolio is subject to testing by the external auditor to determine } \\
\text { appropriateness of loan classification and adequacy of provisions as well as compliance } \\
\text { with valuation policies. For larger loans the oversight is more intense and more frequent. } \\
\text { The supervisory process for the larger systemic banks is well defined, however this is not } \\
\text { defined for all banks. }\end{array}$ \\
\hline EC6 & $\begin{array}{l}\text { rmed on a periodic basis, and in relevant detail, or has access to } \\
\text { hg the classification of credits and assets and provisioning. }\end{array}$ \\
\hline
\end{tabular}




\begin{tabular}{|c|c|}
\hline $\begin{array}{l}\text { Description and } \\
\text { findings re EC6 }\end{array}$ & $\begin{array}{l}\text { As part of the regular prudential reporting, all banks have to file separate, detailed and } \\
\text { comprehensive reports with the NBB on doubtful and impaired loans on a quarterly basis. } \\
\text { For banks that are approved to use internal models, the NBB will receive information when } \\
\text { requested and will provide a detailed analysis of loan classifications and provisioning. } \\
\text { For all banks, annual accounts must be submitted to the NBB. Annual accounts provide } \\
\text { details consistent with the requirements of this criterion. Where necessary, the Bank can } \\
\text { and does request further specific information deemed necessary to for verify and assess the } \\
\text { banks' position in relation to problem assets, provisioning and reserving. Clear evidence for } \\
\text { larger systemic banks, which had received consistent supervision respond to ad hoc } \\
\text { requests. } \\
\text { Article } 44 \text { and } 46 \text { of the Banking Law gives the NBB the power to request from each credit } \\
\text { institution all information it deems necessary to fulfill its supervisory duties. The regulations } \\
\text { clearly provide for this power and evidence that this was exercised by the NBB. }\end{array}$ \\
\hline EC7 & $\begin{array}{l}\text { The supervisor has the power to require a bank to increase its levels of provisions and } \\
\text { reserves and/or overall financial strength if it deems the level of problem assets to be of } \\
\text { concern. }\end{array}$ \\
\hline $\begin{array}{l}\text { Description and } \\
\text { findings re } E C 7\end{array}$ & $\begin{array}{l}\text { The National Bank of Belgium is not empowered to modify the level of provisions reported } \\
\text { by the credit institutions neither in their general purpose financial statements (i.e., in their } \\
\text { accounts). However, corrections can be required by the Bank for prudential purposes, } \\
\text { pursuant to article II.1, §1.b.v of the NBB Regulation of } 15 / 11 / 2011 \text { on own funds. This } \\
\text { article determines the elements that must be deducted from accounting own funds, in } \\
\text { order to determine the regulatory own fund. In this frame, the deduction mentioned in } \\
\text { element (v) of this article relates to the possible and predictable losses and costs for which, } \\
\text { in the opinion of the NBB, the necessary impairment or provisions have not been } \\
\text { accounted for. } \\
\text { In practice, if the NBB identifies weaknesses in provisioning, it has a number of tools to } \\
\text { remedy, such as to apply an adjustment to regulatory own funds. } \\
\text { NBB may also decide, under the Pillar } 2 \text { process, to set a capital add on, above the } \\
\text { minimum solvency requirements, to take into account the potential risk of under } \\
\text { estimation of provision on some exposures (Art } 46 \& 57 \text { ). }\end{array}$ \\
\hline EC8 & $\begin{array}{l}\text { The supervisor assesses whether the classification of the credits and assets and the } \\
\text { provisioning is adequate for prudential purposes. If provisions are deemed to be } \\
\text { inadequate, the supervisor has the power to require additional provisions or to impose } \\
\text { other remedial measures. }\end{array}$ \\
\hline $\begin{array}{l}\text { Description and } \\
\text { findings re } E C 8\end{array}$ & $\begin{array}{l}\text { The NBB has the capacity and power to review loan classification. In practice, the } \\
\text { assessment of the classification of credits and assets will depend upon the risk profile and } \\
\text { impact of the bank. At a minimum, the NBB will receive a self assessment from } \\
\text { management of the bank including a question as to the frequency of review of loan } \\
\text { classifications. There is also a reliance on the external auditor for reviewing policies. } \\
\text { Adequacy of loan classification practices is a standard feature of onsite reviews, for those } \\
\text { banks that are subject to regular onsite review. As stated above, the NBB has the power to } \\
\text { adjust the level of own funds if provisions are assessed as inadequate. }\end{array}$ \\
\hline
\end{tabular}




\begin{tabular}{|c|c|}
\hline EC9 & $\begin{array}{l}\text { The supervisor requires banks to have appropriate mechanisms in place for periodically } \\
\text { assessing the value of risk mitigants, including guarantees and collateral. The valuation of } \\
\text { collateral is required to reflect the net realizable value. }\end{array}$ \\
\hline $\begin{array}{l}\text { Description and } \\
\text { findings re EC9 }\end{array}$ & $\begin{array}{l}\text { Chapter V of the NBB Regulation of } 15 / 11 / 2011 \text { on own funds sets out qualitative } \\
\text { (including periodic assessment requirements - article V.28.\$1) and quantitative } \\
\text { requirements that apply to guarantees and collateral. Specific valuation methods apply } \\
\text { depending on the type of collateral (section IV of Chapter V) so as to obtain a reliable net } \\
\text { realizable value or market value. } \\
\text { The regulations require management to establish a process whereby the risk profile of the } \\
\text { bank's counterparties must be properly determined and continuously monitor in order to } \\
\text { determine (a) the potential losses and the impairments or provisions needed to cover } \\
\text { theses losses and (b) the risk weighted value of the credit for capital adequacy purposes. } \\
\text { These process must include sufficient consideration of benchmark or, where available, } \\
\text { market information on the client. }\end{array}$ \\
\hline EC10 & $\begin{array}{l}\text { Laws, regulations or the supervisor establish criteria for assets to be identified as impaired, } \\
\text { e.g., loans are identified as impaired when there is reason to believe that all amounts due } \\
\text { (including principal and interest) will not be collected in accordance with the contractual } \\
\text { terms of the loan agreement. }\end{array}$ \\
\hline $\begin{array}{l}\text { Description and } \\
\text { findings re EC10 }\end{array}$ & $\begin{array}{l}\text { At a solo level, loans, receivables and debt securities are identified as impaired under } \\
\text { different categories of exposures: } \\
\text { - } \quad \text { for debt securities and receivable held as financial fixed assets, when repayment at } \\
\text { maturity is partly or fully uncertain or compromised (article } 29, \S 2.2 \text { of the RD); } \\
\text { - for all other assets held within the banking book, account must furthermore be } \\
\text { taken of the risk that the counterparty does not meet its contractual commitments } \\
\text { (see also above for the specific requirements for the impairment of problem assets } \\
\text { (article } 35 \text { of the RD); } \\
\text { assets held within the trading book are valued at their market price which normally } \\
\text { reflects all expectations regarding credit risk. } \\
\text { Although these principles are generally high-level, under BGAAP assets are basically } \\
\text { identified as impaired when there is a reason to believe that all amounts due will not be } \\
\text { collected in accordance with the contractual terms of the loan agreement. Prudential } \\
\text { reports require banks to report problem assets by type of assets and by nature of the } \\
\text { problem and by valuation approach (portfolio or individual asset approach). } \\
\text { For accounts that are prepared on a consolidated basis, a financial asset or a group of } \\
\text { financial assets is impaired when there is objective evidence of impairment with a loss } \\
\text { event having an impact on the estimated future cash flows. The "incurred loss" model } \\
\text { implies that losses expected as result of future events, no matter how likely, are not } \\
\text { recognized. Under IFRS, expected losses on loans, receivable and debt securities are not } \\
\text { recognized and do not lead to impairment testing. }\end{array}$ \\
\hline
\end{tabular}




\begin{tabular}{|c|c|}
\hline EC11 & $\begin{array}{l}\text { The supervisor determines that the Board receives timely and appropriate information on } \\
\text { the condition of the bank's asset portfolio, including classification of credits, the level of } \\
\text { provisioning and major problem assets. }\end{array}$ \\
\hline $\begin{array}{l}\text { Description and } \\
\text { findings re EC11 }\end{array}$ & $\begin{array}{l}\text { The NBB Regulation of } 15 / 11 / 2011 \text { on own funds contains a number of governance } \\
\text { requirements on the monitoring and internal reporting (up to the Board) on the various } \\
\text { risks to which the bank is exposed, including asset classification and provisioning. } \\
\text { The Board and senior management are responsible for the preparation of BGAAP financial } \\
\text { accounts every six months. Senior management is responsible for all other information } \\
\text { reported to the NBB and must confirm twice a year that this information if compliant with } \\
\text { reporting standards (article } 44 \text { of the Law of } 22 \text { March 1993). In addition, Pillar III reports } \\
\text { are published pursuant to Chapter XIV of the he NBB Regulation of 15/11/2011 on the own } \\
\text { funds and contain a level of detail regarding credit quality. }\end{array}$ \\
\hline EC12 & $\begin{array}{l}\text { The supervisor requires that valuation, classification and provisioning for large exposures } \\
\text { are conducted on an individual item basis. }\end{array}$ \\
\hline $\begin{array}{l}\text { Description and } \\
\text { findings re EC12 }\end{array}$ & $\begin{array}{l}\text { The accounting law requires impaired exposures to be treated on an individual basis for } \\
\text { valuation and provisions. There was no expressed requirement within the regulations for } \\
\text { valuation, classification and provisioning for large exposures to be conducted on an } \\
\text { individual item basis. }\end{array}$ \\
\hline \multicolumn{2}{|l|}{$\begin{array}{l}\text { Additional } \\
\text { criteria }\end{array}$} \\
\hline AC1 & $\begin{array}{l}\text { Loans are required to be classified when payments are contractually a minimum number of } \\
\text { days in arrears (e.g., 30, 60, } 90 \text { days). Refinancing of loans that would otherwise fall into } \\
\text { arrears does not lead to improved classification for such loans. }\end{array}$ \\
\hline $\begin{array}{l}\text { Description and } \\
\text { findings re } A C 1\end{array}$ & $\begin{array}{l}\text { No such specific requirements exist in this regard under BGAAP (RD of } 23 \text { September 1992) } \\
\text { except that, as indicated above, doubtful loans must be treated separately and reported as } \\
\text { such to the supervisor (article 35, \$2.d of the RD). } \\
\text { At consolidated level (where IFRS apply), IFRS7 (Financial Instruments: Disclosures) requires } \\
\text { entities to disclose additional information on their financial assets that are either past due } \\
\text { or impaired (IFRS7, paragraph 37). Based on this disclosure requirement, the prudential } \\
\text { financial reporting FINREP requires credit institutions to report to the National Bank } \\
\text { detailed information on their past due assets (template } 10 \text { of FINREP). } \\
\text { See also assessment of compliance with Principle } 8 \text { on credit risk. }\end{array}$ \\
\hline $\begin{array}{l}\text { Assessment of } \\
\text { Principle } 9\end{array}$ & Compliant \\
\hline Comments & $\begin{array}{l}\text { The NBB should mandate a minimum supervisory cycle with an appropriate mix of offsite } \\
\text { and onsite reviews of the adequacy of the classification and provisioning policies and } \\
\text { processes of a bank and its implementation. The cycle would ideally be risk-based. . }\end{array}$ \\
\hline Principle 10 & $\begin{array}{l}\text { Large exposure limits. Supervisors must be satisfied that banks have policies and } \\
\text { processes that enable management to identify and manage concentrations within the } \\
\text { portfolio, and supervisors must set prudential limits to restrict bank exposures to single } \\
\text { counterparties or groups of connected counterparties. }\end{array}$ \\
\hline
\end{tabular}




\begin{tabular}{|c|c|}
\hline Essential criteria & \\
\hline $\mathrm{EC1}$ & $\begin{array}{l}\text { Laws or regulations explicitly define, or the supervisor has the power to define, a "group of } \\
\text { connected counterparties" to reflect actual risk exposure. The supervisor may exercise } \\
\text { discretion in applying this definition on a case by case basis. }\end{array}$ \\
\hline $\begin{array}{l}\text { Description and } \\
\text { findings re } E C 1\end{array}$ & $\begin{array}{l}\text { The Belgium regulation on large exposures (LE) is the transposition of the European Capital } \\
\text { Requirement Directive (CRD Directive 2006/48/EC). This is incorporated into the regulatory } \\
\text { framework through NBB Regulation 15/11/2011, Article X.5. } \\
\text { The LE Regime uses the definition of "same counterparty," which is consistent with the CRD } \\
\text { (Article 4), being defined as a natural person or a legal person or a group of (natural or } \\
\text { legal) persons who must be regarded as a whole from the point of view of risk. The concept } \\
\text { of control is further clarified in a Circular (CBFA_2011_03 dated } 27 \text { January 2011) in relation } \\
\text { to the own funds regulation for credit institutions and investment firms. } \\
\\
\text { The CRD provides for national discretion and the Belgium framework has exercised } \\
\text { discretions in relation to the treatment of intra-group transactions. }\end{array}$ \\
\hline EC2 & $\begin{array}{l}\text { Laws, regulations or the supervisor set prudent limits on large exposures to a single } \\
\text { counterparty or a group of connected counterparties. "Exposures" include all claims and } \\
\text { transactions, on-balance sheet as well as off-balance sheet. The supervisor confirms that } \\
\text { senior management monitors these limits and that they are not exceeded on a solo or } \\
\text { consolidated basis. }\end{array}$ \\
\hline & $\begin{array}{l}\text { The LE regime applied in Belgium is largely identical to the Directive } 2006 / 48 / E C \text {. The LE } \\
\text { Rules apply to all credit institutions and investment firms incorporated in Belgium, on a } \\
\text { solo and consolidated level. The regime applies similarly to financial holdings (consolidated } \\
\text { basis only). } \\
\text { As per Article X.5. of the Royal Decree } 15 / 11 / 2011 \text {, an LE is defined as an institution's } \\
\text { exposure to a client or group of connected clients where its value is equal to or exceeds } \\
10 \text { percent of its own funds. In terms of the limit framework, banks are required to adhere } \\
\text { to the following definitions: } \\
\qquad \quad 10 \text { percent or more of a bank's capital is defined as a large exposure; and } \\
\quad 25 \text { percent of a bank's capital is the limit for an individual large exposure to a } \\
\quad \text { counterparty or a group of connected counterparties. } \\
\text { Consistent with the EU Directive, several types of exposures are not captured in the LE } \\
\text { regime, including: in the case of foreign exchange transactions, exposures incurred in the } \\
\text { ordinary course of settlement during the two working days following payment; for the } \\
\text { purchase or sale of securities, exposures incurred in the ordinary course of settlement } \\
\text { during five working days following payments or delivery of the securities whichever the } \\
\text { earlier etc. } \\
\text { For off-balance sheet the exposure value is calculated as its balance-sheet value (i.e., no risk } \\
\text { weight, degree of risk or conversion factor is applicable in this context). The exposure value } \\
\text { for derivatives, repurchase transactions, securities or commodities lending or borrowing } \\
\text { transactions, long settlement transactions and margin lending transactions are determined } \\
\text { according to the Credit Counterparty Risk provisions (i.e., MtM Method, Original Exposure } \\
\text { Method, Standardized Method, Internal Model Method). }\end{array}$ \\
\hline
\end{tabular}




\begin{tabular}{|c|c|}
\hline & $\begin{array}{l}\text { The LE regime allows for smaller banks to exceed the } 25 \text { percent limit. In this instance, } \\
\text { where the client is an institution, the value shall not exceed } 25 \text { percent of the credit } \\
\text { institution's own funds or EUR } 150 \text { million, whichever is the higher, provided that the sum } \\
\text { of exposure values after taking into account eligible credit risk mitigation techniques to all } \\
\text { connected clients that are not institutions does not exceed } 25 \text { percent of the credit } \\
\text { institution's own funds. } \\
\text { Where the amount of EUR } 150 \text { million is higher than } 25 \text { percent of the own funds of the } \\
\text { lending credit institution, the value of the exposure, after credit risk mitigation, shall not } \\
\text { exceed "a reasonable limit in terms of the credit institution's own funds." That limit is } \\
\text { determined by the credit institution itself, consistent with its policies and procedures to } \\
\text { address and control concentration risk and shall not be higher than } 100 \text { percent of the } \\
\text { credit institution's own funds. } \\
\text { Therefore the LE regime permits smaller banks to extend exposures of up to } 100 \text { percent of } \\
\text { capital after taking credit risk mitigation into account. This concession significantly weakens } \\
\text { the regime and exposes smaller banks to considerable risk. In practice, smaller banks do } \\
\text { not have access to deep capital markets to quickly raise capital in the event an exposure to } \\
\text { an obligor defaults or becomes impaired. Smaller banks typically have less sophisticated } \\
\text { risk management systems to monitor and manage exposures with real time data and thus } \\
\text { are less able to respond in a timely fashion to changes in risk profile. } \\
\text { A small sample of LE data sighted as part of this assessment indicates that the exposures of } \\
\text { banks to single counterparties are not insignificant: } \\
\text { Bank } 1 \text { : individual exposure to other credit institution after CRM } 71 \text { percent; } \\
\text { sovereigns over } 10 \text { percent approx } 150 \text { percent. } \\
\text { Bank 2: Group } 155 \text { percent } \\
\text { Bank } 3: 300 \text { percent sovereign. } \\
\text { Bank } 4 \text { Unable to report March } 2012 \\
\text { Bank } 6: \text { Aggregate LE to } 6 \text { corporates above } 10 \text { percent in total approx } 70 \text { percent } \\
\text { Total Capital. }\end{array}$ \\
\hline EC3 & $\begin{array}{l}\text { The supervisor determines that a bank's management information systems identify and } \\
\text { aggregate on a timely basis exposure to individual counterparties and groups of connected } \\
\text { counterparties. }\end{array}$ \\
\hline $\begin{array}{l}\text { Description and } \\
\text { findings re EC3 }\end{array}$ & $\begin{array}{l}\text { Article } \mathrm{X} 13 \text { requires that credit institutions have in place adequate organizational and } \\
\text { internal control systems enabling them to identify, record, monitor and manage all large } \\
\text { exposures according to their internal policies and procedures. }\end{array}$ \\
\hline EC4 & $\begin{array}{l}\text { The supervisor confirms that a bank's risk management policies and processes establish } \\
\text { thresholds for acceptable concentrations of credit and require that all material } \\
\text { concentrations be reviewed and reported periodically to the Board. }\end{array}$ \\
\hline $\begin{array}{l}\text { Description and } \\
\text { findings re EC4 }\end{array}$ & $\begin{array}{l}\text { The Circular relating to risk management for large exposures was first published in } 2006 \\
\text { (Circular PPB-2006-17-CPB of } 20 \text { December 2006) and describes best practices and } \\
\text { reporting requirements under Pillar } 2 \text { for sectoral and geographical concentrations. This } \\
\text { Circular was updated more recently by Circular CBFA_2010_27 of } 16 \text { December } 2010 \\
\text { following the publication of CEBS/EBA guidelines on risk concentrations (GL } 31 \text { - } 2 \\
\text { September 2010). The Circular requires a bank to have adequate arrangements in place for } \\
\text { actively controlling, monitoring and mitigating concentration risk. Banks should also use } \\
\text { internal limits, thresholds or similar concepts, as appropriate. }\end{array}$ \\
\hline
\end{tabular}




\begin{tabular}{|c|c|}
\hline EC5 & $\begin{array}{l}\text { The supervisor regularly obtains information that enables concentrations within a bank's } \\
\text { portfolio, including sectoral, geographical and currency exposures, to be reviewed. The } \\
\text { supervisor has the power to require banks to take remedial actions in cases where } \\
\text { concentrations appear to present significant risks. }\end{array}$ \\
\hline $\begin{array}{l}\text { Description and } \\
\text { findings re EC5 }\end{array}$ & $\begin{array}{l}\text { Reporting requirements of COREP Pillar } 1 \text { table } 90.18 \text { require, on a quarterly basis, that } \\
\text { institutions report all their large exposures (top } 20 \text { for IRB banks). The information } \\
\text { requested includes: category of exposure, amount of credit risk mitigation, indirect } \\
\text { exposures, total exposures before and after weightings, distinction banking and trading } \\
\text { book. The example of LE reporting submitted by the NBB does not however, provide } \\
\text { sectoral, geographical or currency detail. } \\
\text { For financial holding companies reporting of LE data is on a six monthly basis, which } \\
\text { accounts for the absence of data reported by Bank } 4 \text { in EC2.Quaretrly reporting for financial } \\
\text { holding companies that are material has been initiated to help comply with EBA reporting } \\
\text { requests. } \\
\text { The NBB only receives geographical concentration data from regulated banks on an annual } \\
\text { basis, as opposed to more frequently such as the quarterly frequency of other prudential } \\
\text { returns. The EC requires "regular" information of a geographical and sectoral nature be } \\
\text { provided to the supervisor. The majority of prudential reporting is quarterly, which allows } \\
\text { the supervisor to perform an integrated and comprehensive risk assessment. The reporting } \\
\text { could be increased to allow supervisors to respond to risk signals in a timely fashion } \\
\text { especially where exposures within the same asset class demonstrate divergent risks } \\
\text { depending upon geographical characteristics. }\end{array}$ \\
\hline \multicolumn{2}{|l|}{$\begin{array}{l}\text { Additional } \\
\text { criteria }\end{array}$} \\
\hline AC1 & $\begin{array}{l}\text { Banks are required to adhere to the following definitions: } \\
\text { - } 10 \text { percent or more of a bank's capital is defined as a large exposure; and } \\
25 \text { percent of a bank's capital is the limit for an individual large exposure to a } \\
\text { counterparty or a group of connected counterparties. }\end{array}$ \\
\hline $\begin{array}{l}\text { Description and } \\
\text { findings re } A C 1\end{array}$ & $\begin{array}{l}\text { As foreseen by EU Directive, some temporary deviations are authorized ex ante under } \\
\text { conditions for large concentrations resulting from trading book positions. } \\
\text { The NBB has indicated that minor deviations from the above limits may be acceptable, } \\
\text { especially if explicitly temporary or related to very small or specialized banks. }\end{array}$ \\
\hline $\begin{array}{l}\text { Assessment of } \\
\text { Principle } 10\end{array}$ & Largely compliant \\
\hline Comments & $\begin{array}{l}\text { The LE regime permits small banks to extend exposures of up to } 100 \text { percent of capital } \\
\text { after taking account of credit risk mitigation. This significantly weakens the regime for this } \\
\text { group of banks, allowing those banks the ability to build-up excessive risk concentrations. } \\
\text { In practice, smaller banks do not have access to deep capital markets to quickly raise } \\
\text { capital in the event an exposure to an obligor defaults or becomes impaired. Smaller banks } \\
\text { typically have less sophisticated risk management systems to monitor and manage } \\
\text { exposures with real time data and thus are less able to respond to changes in risk in a }\end{array}$ \\
\hline
\end{tabular}




\begin{tabular}{|c|c|}
\hline & $\begin{array}{l}\text { timely fashion. } \\
\text { The credit risk management framework does not require large exposures to be } \\
\text { approved/reviewed by senior management or the Board. Without this requirement, } \\
\text { excessively large exposures could be made by less experienced staff of the bank that are } \\
\text { not in the position to monitor risk concentrations (the credit risk framework is discussed in } \\
\text { CP8). } \\
\text { The substance of this Principle requires supervisors to establish prudential limits to restrict } \\
\text { bank exposures to single counterparties or groups of connected counterparties. } \\
\text { Furthermore, without the requirement for large exposures to be approved/reviewed by the } \\
\text { Board could result in smaller banks approving large exposures, which results in a build-up } \\
\text { of excessive risk. }\end{array}$ \\
\hline Principle 11 & $\begin{array}{l}\text { Exposures to related parties. In order to prevent abuses arising from exposures (both on } \\
\text { balance sheet and off balance sheet) to related parties and to address conflict of interest, } \\
\text { supervisors must have in place requirements that banks extend exposures to related } \\
\text { companies and individuals on an arm's length basis; these exposures are effectively } \\
\text { monitored; appropriate steps are taken to control or mitigate the risks; and write-offs of } \\
\text { such exposures are made according to standard policies and processes. }\end{array}$ \\
\hline \multicolumn{2}{|r|}{ ( } \\
\hline EC 1 & $\begin{array}{l}\text { Laws or regulations explicitly provide, or the supervisor has the power to provide, a } \\
\text { comprehensive definition of "related parties." This should consider the parties identified in } \\
\text { the footnote to the Principle. The supervisor may exercise discretion in applying this } \\
\text { definition on a case by case basis. }\end{array}$ \\
\hline $\begin{array}{l}\text { Description and } \\
\text { findings re } E C 1\end{array}$ & $\begin{array}{l}\text { The Belgium regulatory framework for related party exposures is comprised of a number of } \\
\text { separate documents. } \\
\text { There is no specific Circular explicitly defining related party exposure. However, Article } 28 \\
\text { of the BL, requires "each credit institution to grant loans, credit facilities or guarantees to its } \\
\text { officers or managers under the same conditions, up to the same amounts and against the } \\
\text { same securities as those applicable to their clients." Article } 28 \text { also requires reporting to the } \\
\text { NBB of related party transactions to companies or institutions in which their officers or } \\
\text { managers or spouses personally own a direct or indirect qualifying holding. What is missing } \\
\text { from the definition in Article } 28 \text { is a reference to transactions with material shareholders of } \\
\text { the credit institution. Without a reference to material or significant shareholders, it is } \\
\text { questionable whether the definitions contained within the Banking Law could be } \\
\text { considered comprehensive. Further, loans to shareholders could potentially be a feature } \\
\text { across the banking sector and not an insignificant practice in Belgium banking. } \\
\text { To some extent, the LE regime is applicable as it provides limits on exposures to } \\
\text { counterparties, though the LE regime does not define a related party nor does it explicitly } \\
\text { reference related parties. } \\
\text { The Belgium accounting law as well as regulation over supplementary supervision } \\
\text { (transposing the EU Directive on conglomerates) define groups and related companies. } \\
\text { Identification of group relationships, both up- and downstream, is required. In this case, the } \\
\text { accounting law provides a more comprehensive set of definitions and importantly includes } \\
\text { shareholders. }\end{array}$ \\
\hline
\end{tabular}




\begin{tabular}{|c|c|}
\hline & 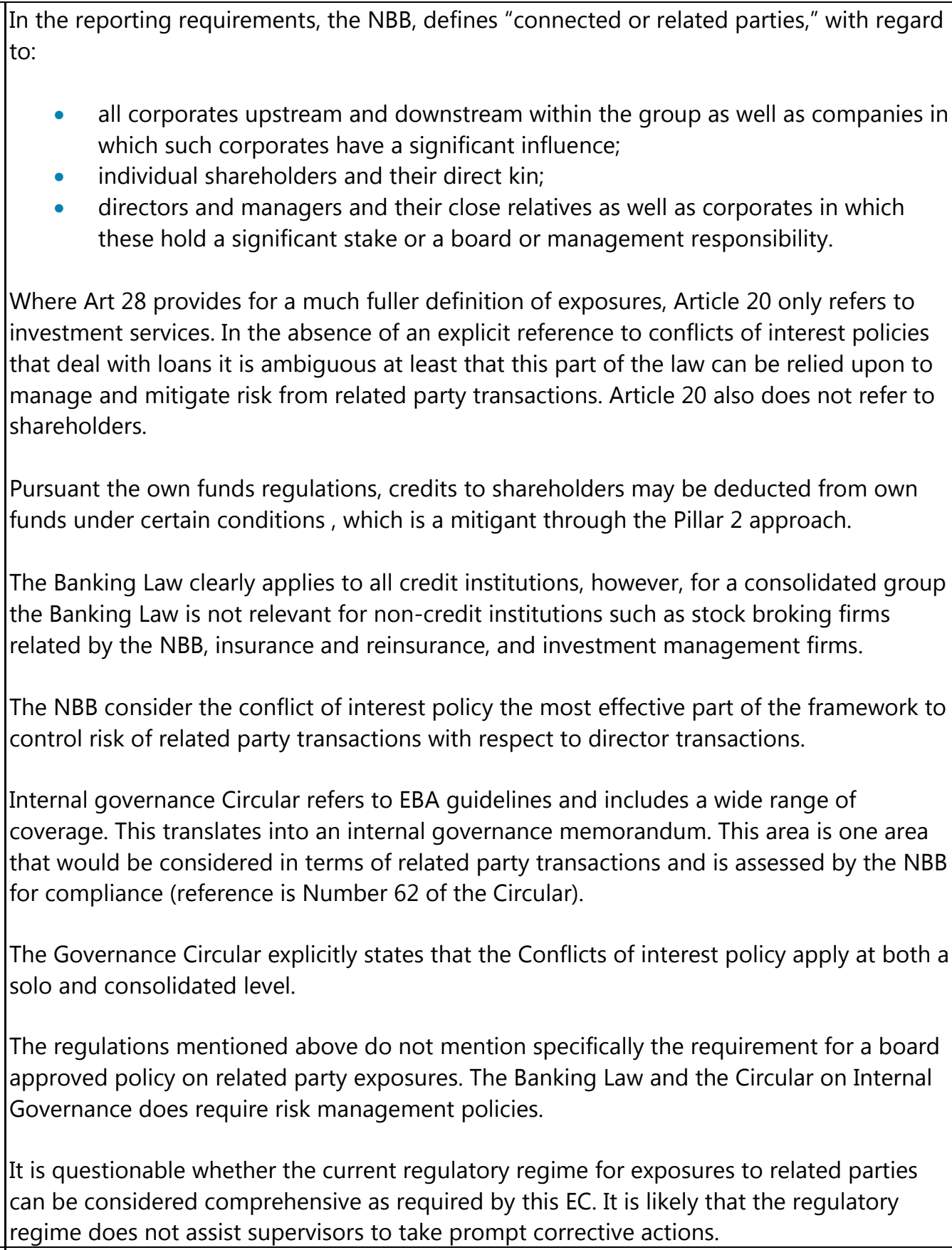 \\
\hline EC2 & $\begin{array}{l}\text { Laws, regulations or the supervisor require that exposures to related parties may not be } \\
\text { granted on more favorable terms (ie for credit assessment, tenor, interest rates, } \\
\text { amortization schedules, requirement for collateral) than corresponding exposures to non- } \\
\text { related counterparties. }\end{array}$ \\
\hline $\begin{array}{l}\text { Description and } \\
\text { findings re EC2 }\end{array}$ & $\begin{array}{l}\text { The Banking Law requires integrity policy (article 20, } \S 3 \text { ). The Banking Law does not } \\
\text { however require the policy to include specific measures to manage and mitigate the risks } \\
\text { associated with exposures to related parties or provide definitions of related parties. Article } \\
20 \text { bis } \$ 2 \text { does explicitly make reference to measures to prevent conflicts of interests } \\
\text { between banks and directors and employees for what concerns investment services. Article } \\
28 \text { explicitly states that credit institutions are by law requested to grant credits, directly or } \\
\text { indirectly, and issue guarantees to their directors and managers at the same conditions }\end{array}$ \\
\hline
\end{tabular}




\begin{tabular}{|c|c|}
\hline & than those prevailing for their customer and breaches are criminally prosecutable. \\
\hline EC3 & $\begin{array}{l}\text { The supervisor requires that transactions with related parties and the write-off of related- } \\
\text { party exposures exceeding specified amounts or otherwise posing special risks are subject } \\
\text { to prior approval by the bank's Board. The supervisor requires that Board members with } \\
\text { conflicts of interest are excluded from the approval process. }\end{array}$ \\
\hline $\begin{array}{l}\text { Description and } \\
\text { findings re EC3 }\end{array}$ & $\begin{array}{l}\text { The regulations relevant to exposures to related parties as described in EC1 do not refer to } \\
\text { requirements for write-off or limits that would need to be approved by the board. It is } \\
\text { questionable whether the regulatory framework works together in practice to allow } \\
\text { supervisors the ability to appropriately mitigate and monitor this risk or provide at least } \\
\text { guidance about write offs. } \\
\text { Strategic decision requirement in the Banking Law (include reference) could be considered } \\
\text { as a possible way to capture the risk of transactions with a related party of a certain } \\
\text { importance. As far as they are considered a strategic decision, they require decision by the } \\
\text { bank's Board and prior approval by the NBB. It is very unclear, however, how banks would } \\
\text { interpret the application of the strategic decisions requirements to related parties and as } \\
\text { such difficult to consider this a reliable mechanism for board approval. } \\
\text { The provisions in the Sound Governance Circular (PPB-2007-6-CPA) relating to a conflicts } \\
\text { of interest policy do not give guidance about how exposures to related parties should be } \\
\text { treated to account for their specific prudential risk. The Circular describes a number of } \\
\text { appropriate ways to manage conflicts of interest, however there is not a level of detail that } \\
\text { aligns with the requirements in this criterion. The result being that a bank could have in } \\
\text { place a conflicts of interest policy, which takes account of the Circular but does not } \\
\text { adequately mitigate the special risks associated with exposures to related parties. For } \\
\text { example, there is no reference to the need for exposures to related parties to be approved } \\
\text { by board. }\end{array}$ \\
\hline EC4 & $\begin{array}{l}\text { The supervisor requires that banks have policies and processes in place to prevent persons } \\
\text { benefiting from the exposure and/or persons related to such a person from being part of } \\
\text { the process of granting and managing the exposure. }\end{array}$ \\
\hline $\begin{array}{l}\text { Description and } \\
\text { findings re EC4 }\end{array}$ & $\begin{array}{l}\text { The Internal Governance Circular (principle VIII) requires that internal conduct rules are } \\
\text { enacted and that appropriate measures are taken by the bank regarding, amongst other } \\
\text { things, conflicts of interests. }\end{array}$ \\
\hline EC5 & $\begin{array}{l}\text { Laws or regulations set, or the supervisor has the power to set on a general or case by case } \\
\text { basis, limits for exposures to related parties, to deduct such exposures from capital when } \\
\text { assessing capital adequacy, or to require collateralisation of such exposures. When limits } \\
\text { are set on aggregate exposures to related parties those are at least as strict as those for } \\
\text { single counterparties, or groups of connected counterparties. }\end{array}$ \\
\hline $\begin{array}{l}\text { Description and } \\
\text { findings re EC5 }\end{array}$ & $\begin{array}{l}\text { In its regulation on capital adequacy, the supervisor has reserved itself the right, for all } \\
\text { exposures granted under more favorable terms than "at arm's length" }{ }^{5} \text {, to deduct such } \\
\text { exposures from the own funds, thus requiring full coverage of these exposures by own } \\
\text { funds. Credit granted to shareholders in order to subscribe capital instruments, or when } \\
\text { there's no evidence that the shareholders may redeem the credit on basis of other financial } \\
\text { resources than its investments in the related bank, shall also be deduced from own funds. }\end{array}$ \\
\hline
\end{tabular}

\footnotetext{
${ }^{5}$ Regardless of the counterpart or its relationship to the bank or its leaders.
} 


\begin{tabular}{|c|c|}
\hline & $\begin{array}{l}\text { This requirement was recently introduced. } \\
\text { The relevant regulations and rules text include: NBB Regulation 15/11/2011, article II.1; } \\
\text { Circular PPB-2007-1-CPB, comments to article II.1 §§ } 1 \text { and 5; and } \\
\text { Large exposure regime (see CP 10). } \\
\text { The LE regime provides for exemptions for intra-group transactions, which would negate } \\
\text { the limit framework. } \\
\text { In practice, the NBB also deals with this risk via its Pillar } 2 \text { assessment and deducts from } \\
\text { capital accordingly. } \\
\text { In terms of intra-group exposures, the Belgian rules were modified during the transposition } \\
\text { of Directive 2009/111/EC (CRD II), which does not impose limits on intra-group } \\
\text { transactions. The NBB has commenced a transition to a tougher requirement, which will } \\
\text { impose a limit of } 100 \text { percent of own funds for intra-group transactions, mainly where the } \\
\text { group counterparty is domiciled outside of Belgium. In practice, the treatment of intra- } \\
\text { group exposures under the Large Exposure Regime will apply to Belgian institutions within } \\
\text { a cross-border group. A transitional period until } 31 \text { December } 2012 \text { has been permitted } \\
\text { until the new treatment comes into force. Existing LE rules currently in place include: } \\
\text { 1. For those exposures to group entities, which receive a } 0 \text { percent risk weight under } \\
\text { the Standardised Approach, no limit is applicable. } \\
\text { 2. Subject to NBB's prior approval, exposures to a domestically regulated subsidiary, } \\
\text { the parent company or a subsidiary of that parent company, are exempted from } \\
\text { the LE Regime provided that the following conditions are met: (a) funding is } \\
\text { mainly provided by professional counterparts and (b) non-professional deposits } \\
\text { are limited in volume relative to the Belgian banking sector. } \\
\text { 3. Exposures to subsidiaries subject to a control on a consolidated basis are } \\
\text { exempted from the LE Regime. } \\
\text { 4. Exposures to the parent company or other subsidiaries of that parent company, } \\
\text { that are subject to a control on a consolidated basis or equivalent, are subject to } \\
\text { the Large Exposure Regime up to } 25 \text { percent of own funds. In practice, the limit is } \\
\text { thus set at } 100 \text { percent of the own funds. }\end{array}$ \\
\hline EC6 & $\begin{array}{l}\text { The supervisor requires banks to have policies and processes to identify individual } \\
\text { exposures to related parties as well as the total amount of such exposures, and to monitor } \\
\text { and report on them through an independent credit review process. The supervisor confirms } \\
\text { that exceptions to policies, processes and limits are reported to the appropriate level of } \\
\text { senior management and, if necessary, to the Board, for timely action. The supervisor also } \\
\text { confirms that senior management monitors related party transactions on an ongoing basis, } \\
\text { and that the Board also provides oversight of these transactions. }\end{array}$ \\
\hline & $\begin{array}{l}\text { The Belgium rules text for exposures to related parties does not specifically address the } \\
\text { requirements in this criterion. } \\
\text { The criterion refers to the supervisor requiring banks to identify total amount of exposures } \\
\text { to related parties. The relevant text of the Banking Law (regulations do not include a limit } \\
\text { framework that would apply. The other aspect of this criterion relates to the need for an } \\
\text { independent credit review process for related party exposures. In the case of exposures to } \\
\text { material shareholders, the Circular for Internal Governance is not referred to in the Banking } \\
\text { Law it is not apparent how a bank would design its policy framework to account for this risk } \\
\text { and ensure an independent credit approval process would be established. }\end{array}$ \\
\hline
\end{tabular}




\begin{tabular}{|c|c|}
\hline & $\begin{array}{l}\text { Board approval and oversight is not explicit within the regulations to exercise governance } \\
\text { (principle VIII) do not align with the with the requirements of this EC. } \\
\text { An integrated process for the identification, monitoring and reporting are approval by the } \\
\text { board but is not explicitly provided for in the regulations.. If each of the regulations are } \\
\text { applied specifically to related party exposures, the special risks of exposures to related } \\
\text { parties might be addressed. There is however, an inherent weakness in the regulatory } \\
\text { framework where there is reliance on various regulations to mitigate a specific risk, where } \\
\text { the regulations are not designed with the intent of mitigating that risk. }\end{array}$ \\
\hline EC7 & The supervisor obtains and reviews information on aggregate exposures to related parties. \\
\hline $\begin{array}{l}\text { Description and } \\
\text { findings re EC7 }\end{array}$ & $\begin{array}{l}\text { In the reporting provided to the NBB by credit institutions on a solo basis, information on } \\
\text { related companies, their balance sheet, their profit and loss account and the off-balance } \\
\text { sheet commitments is submitted. In the public annual accounts on a solo basis, banks have } \\
\text { to disclose any transactions with a related companies or individuals. On a consolidated } \\
\text { basis, this information is based on the international accounting standard IAS } 24 \text { "Related } \\
\text { party disclosures" and these disclosures are made public. In the reporting transmitted to } \\
\text { the NBB on consolidated basis, information on balance sheet, profit and loss account and } \\
\text { off-balance sheet items is included. }\end{array}$ \\
\hline $\begin{array}{l}\text { Assessment of } \\
\text { Principle } 11\end{array}$ & Compliant \\
\hline Comments & $\begin{array}{l}\text { An integrated process for the identification, monitoring and reporting of exposures to } \\
\text { related parties approved by the board is not explicitly provided for in the regulations. }\end{array}$ \\
\hline Principle 12 & $\begin{array}{l}\text { Country and transfer risks. Supervisors must be satisfied that banks have adequate } \\
\text { policies and processes for identifying, measuring, monitoring and controlling country risk } \\
\text { and transfer risk in their international lending and investment activities, and for maintaining } \\
\text { adequate provisions and reserves against such risks. }\end{array}$ \\
\hline \multicolumn{2}{|r|}{ (1) } \\
\hline EC1 & $\begin{array}{l}\text { The supervisor determines that a bank's policies and processes give due regard to the } \\
\text { identification, measurement, monitoring and control of country risk and transfer risk. } \\
\text { Exposures are identified and monitored on an individual country basis (in addition to the } \\
\text { end-borrower/end-counterparty basis). Banks are required to monitor and evaluate } \\
\text { developments in country risk and in transfer risk and apply appropriate countermeasures. }\end{array}$ \\
\hline $\begin{array}{l}\text { Description and } \\
\text { findings re EC1 }\end{array}$ & $\begin{array}{l}\text { The NBB has not issued specific guidance on country and transfer risk (other than guidance } \\
\text { relating to credit risk and concentration risk in general). As a result, country and transfer } \\
\text { risk is a subset of credit risk and the regulatory framework for country and transfer risk } \\
\text { consists of the credit risk Circular (Circular letter NBB_2011_09 of } 20 \text { December 2011) on } \\
\text { internal control, which uses as its base the Basel Document "Principles of Credit Risk } \\
\text { Management" of } 2000 . \\
\text { When banks extend credit internationally, an assessment of the credit risk is made against } \\
\text { the principles of credit risk generally rather than with an explicit consideration of country } \\
\text { and transfer risk. The result of the assessment is summarized in the credit risk scorecard } \\
\text { which is updated at least annually. The assessment criteria are those described in the Basel }\end{array}$ \\
\hline
\end{tabular}




\begin{tabular}{|c|c|}
\hline & $\begin{array}{l}\text { Document "Principles of Credit Risk Management" of 2000, although this document does } \\
\text { not refer to country and transfer risk. It could be argued that Principle 3: of the BCBS } \\
\text { document informs this requirement, which states "Banks should identify and manage } \\
\text { credit risk inherent in all products and activities. Banks should ensure that the risks of } \\
\text { products and activities new to them are subject to adequate risk management procedures } \\
\text { and controls before being introduced or undertaken." However, without there is no } \\
\text { minimum expectations of risk management. } \\
\text { The NBB assesses compliance with credit risk of which country and transfer risk is a subset } \\
\text { through its main supervisory activities i.e., onsite examinations; report to management on } \\
\text { credit risks; and reports of an accredited auditor. } \\
\text { Without specific requirements for country and transfer risk, it is not certain how the NBB } \\
\text { would ensure that banks are applying a consistent risk management approach or whether } \\
\text { indeed there is a minimum standard that would be expected. No specific guidance has } \\
\text { been produced for banks outside of the general BCBS credit risk framework. } \\
\text { The lack of explicit guidance also impacts the work of the external auditors. It weakens the } \\
\text { quality of the control reports that the NBB utilizes: self assessment of internal controls and } \\
\text { the external auditors report. } \\
\text { In the assessment of estimates of PD and LGD for internal model users, there is } \\
\text { consideration of country risks. Indeed, the NBB recently assessed more specifically the } \\
\text { exposures to sovereign assets within the eurozone and the PD/LGD assigned to these } \\
\text { exposure in order to assess the appropriateness of these estimates. But internal model } \\
\text { accreditation is a small percentage of the regulated population (in terms of number of } \\
\text { accredited banks for internal models) and the assessment by the NBB was initiated after } \\
\text { considerable issues with this portfolio where transfer risk had crystallized. } \\
\text { The NBB has issued a Circular letter (Circular letter CBFA_2010-27 of } 13 \text { December 2010) } \\
\text { relating more specifically to the management and monitoring of risk concentration. The } \\
\text { Circular does include reference to sectoral and geographical concentrations. This addition } \\
\text { enhances the regulatory framework somewhat. }\end{array}$ \\
\hline EC2 & $\begin{array}{l}\text { The supervisor confirms that banks have information systems, risk management systems } \\
\text { and internal control systems that accurately monitor and report country exposures and } \\
\text { ensure adherence to established country exposure limits. }\end{array}$ \\
\hline $\begin{array}{l}\text { Description and } \\
\text { findings re } E C 2\end{array}$ & $\begin{array}{l}\text { Pursuant the different rules mentioned in EC1, (Basel Document "Principles of Credit Risk } \\
\text { Management" of } 2000 \text { and Circular letter CBFA_2010-27 of } 13 \text { December } 2010 \text { - banks are } \\
\text { required to identify, control and report country risk exposures. This is a general } \\
\text { requirement rather than specifically relating to this criterion. } \\
\text { The assessment of compliance with country and transfer risks is the same as described in } \\
\text { EC1. } \\
\text { Exposure to country risk is mainly assessed through prudential reporting. Quarterly reports } \\
\text { to the NBB (table } 40.80 \text { ) indicate the amount of assets and debts according to the } \\
\text { localization of the counterparties. On an annual basis, each institutions report also (table } \\
90.34 \text { of prudential reporting), on consolidated basis, their risk exposures (as defined by } \\
\text { the solvency regulation) per country when these exposures exceed } 3 \text { pc of their own funds. } \\
\text { These reports enable the NBB to monitor the evolution of country risk. The NBB receive }\end{array}$ \\
\hline
\end{tabular}




\begin{tabular}{|c|c|}
\hline & $\begin{array}{l}\text { quarterly and annual information, which allows them to assess a bank's exposure to } \\
\text { countries. } \\
\text { The NBB also carries out periodic assessments of risk of some countries where Belgian } \\
\text { banks have material exposures to better assess the risks taken by these banks and } \\
\text { challenge them. These macro-financial analyses incorporate developments in the real and } \\
\text { the financial sector include as well an assessment of the main risks. These analyses are } \\
\text { presented in the Macro Financial Committee and the NBB Board of Directors. The main } \\
\text { countries that have been considered are: Greece, Spain, Italy, Hungary, Ireland, The } \\
\text { Netherlands, France and Germany (which a specific attention on the real estate market for } \\
\text { these three last countries). This is exceptional analysis rather than part of the quarterly } \\
\text { monitoring that would be performed by supervisory teams. }\end{array}$ \\
\hline EC3 & $\begin{array}{l}\text { There is supervisory oversight of the setting of appropriate provisions against country risk } \\
\text { and transfer risk. There are different international practices, which are all acceptable as } \\
\text { long as they lead to risk-based results. These include: } \\
\text { - The supervisor (or some other official authority) decides on appropriate minimum } \\
\text { provisioning by setting fixed percentages for exposures to each country. } \\
\text { The supervisor (or some other official authority) sets percentage ranges for each } \\
\text { country, and the banks may decide, within these ranges, which provisioning to } \\
\text { apply for the individual exposures. } \\
\text { The bank itself (or some other body such as the national bankers' association) sets } \\
\text { percentages or guidelines or even decides for each individual loan on the } \\
\text { appropriate provisioning. The provisioning will then be judged by the external } \\
\text { auditor and/or by the supervisor. }\end{array}$ \\
\hline $\begin{array}{l}\text { Description and } \\
\text { findings re EC3 }\end{array}$ & $\begin{array}{l}\text { The NBB has not issued specific guidance of appropriate provisions against country and } \\
\text { transfer risk. There are specific examples where the NBB has required value adjustments on } \\
\text { exposures such as in the case of Greek sovereign bonds to haircut the value in trading } \\
\text { books. } \\
\text { Nonetheless, there was no evidence of supervisors assessing country and transfer risk with } \\
\text { a consistent framework using minimum provisions or fixed percentages to exposures on a } \\
\text { country by country basis. } \\
\text { Since the introduction of IFRS accounting rules on consolidated basis, NBB has no power to } \\
\text { impose additional value adjustments covering specifically country and transfer risk at an } \\
\text { early stage. NBB may nevertheless require additional value adjustments for own funds } \\
\text { purposes when it assesses, on case by case basis, that the institution has not made a } \\
\text { sufficiently prudent adjustments. On the basis of an assessment of value adjustments made } \\
\text { by insurance and banks, NBB has issued some recommendations (additional value } \\
\text { adjustment) to some institutions. } \\
\text { For banks using IRB Models, the NBB will assess whether models take into account the } \\
\text { country risks for the calibration of PD and LGD. However, data suggests a significant } \\
\text { divergence in estimates exist for LGD estimates as an example: we saw reports, which } \\
\text { showed that estimates of LGD for Greek Sovereign bonds ranged from } 20 \text { percent to } 70 \\
\text { percent; Portugal from } 10 \text { percent to } 40 \text { percent; Ireland } 10 \text { percent to } 40 \text { percent. While it is } \\
\text { not expected that internal models will produce precisely the same estimates, the } \\
\text { divergence and impact on RWA's for quite significant portfolios could be considered }\end{array}$ \\
\hline
\end{tabular}




\begin{tabular}{|c|c|}
\hline & $\begin{array}{l}\text { material. } \\
\text { At a minimum, the annual assessment of the ICAAP (including stress testing process) } \\
\text { provides the NBB with an opportunity to assess the level of these risks and the adequacy of } \\
\text { the policies and procedures for identifying and monitoring the country and transfer risk. } \\
\text { While the NBB is able to point to some oversight and supervisory actions, monitoring is not } \\
\text { yet systematic and ongoing. }\end{array}$ \\
\hline EC4 & $\begin{array}{l}\text { The supervisor obtains and reviews sufficient information on a timely basis on the country } \\
\text { risk and transfer risk of individual banks. }\end{array}$ \\
\hline $\begin{array}{l}\text { Description and } \\
\text { findings re EC4 }\end{array}$ & $\begin{array}{l}\text { Credit institution report to the NBB on a quarterly basis (table } 41.80 \text { ), the amount of assets } \\
\text { and debts according to the localization of the counterparties. On an annual basis, each } \\
\text { institutions report also (table } 90.34 \text { of prudential reporting), on consolidated basis, their } \\
\text { risk exposures (as defined by the solvency regulation) per country when these exposures } \\
\text { exceed } 3 \text { pc of their own funds. These reports enable the NBB to monitor the evolution of } \\
\text { country risk. } \\
\text { While the consolidated requirements of the reporting structure are clear, the solo } \\
\text { requirements are not. Annual reporting is not sufficiently timely. The reporting } \\
\text { requirements in Belgium require annual returns to be lodged by no later than six months } \\
\text { after the end of financial year, which in practice together with the lag in supervisors } \\
\text { reviewing the data, would not be sufficiently timely for the supervisors to react timely to a } \\
\text { build-up in risks. }\end{array}$ \\
\hline $\begin{array}{l}\text { Assessment of } \\
\text { Principle } 12\end{array}$ & Largely compliant \\
\hline Comment & $\begin{array}{l}\text { The NBB has not issued specific guidance on country and transfer risk (other than guidance } \\
\text { relating to credit risk and concentration risk in general), and may not impose any more } \\
\text { specific reserves against such risks. }\end{array}$ \\
\hline Principle 13 & $\begin{array}{l}\text { Market risk. Supervisors must be satisfied that banks have in place policies and processes } \\
\text { that accurately identify, measure, monitor and control market risks; supervisors should have } \\
\text { powers to impose specific limits and/or a specific capital charge on market risk exposures, } \\
\text { if warranted. }\end{array}$ \\
\hline Essential criteria & \\
\hline EC1 & $\begin{array}{l}\text { The supervisor determines that a bank has suitable policies and processes that clearly } \\
\text { articulate roles and responsibilities related to the identification, measuring, monitoring and } \\
\text { control of market risk. The supervisor is satisfied that policies and processes are adhered to } \\
\text { in practice and are subject to appropriate Board and senior management oversight. }\end{array}$ \\
\hline $\begin{array}{l}\text { Description and } \\
\text { findings re EC1 }\end{array}$ & $\begin{array}{l}\text { The core of the market risk regulatory framework is a general reference in Article } 20 \text { of the } \\
\text { Banking Law regarding a sound and safe banking organization. The more specific market } \\
\text { risk requirements contained in the Circulars listed below align with the European Directive } \\
\text { (revised most recently } 2010 / 76 / E U \text { of } 24 \text { November 2010): } \\
\text { - NBB Regulation } 15 / 11 / 2011 \text {, articles I.6 and IX.84. } \\
\text { Circular NBB_2012_03, } 10 \text { May 2012, transposing the CEBS/EBA guidelines related } \\
\text { to the management of operational risks in market-related activities. }\end{array}$ \\
\hline
\end{tabular}




\begin{tabular}{|c|c|}
\hline & 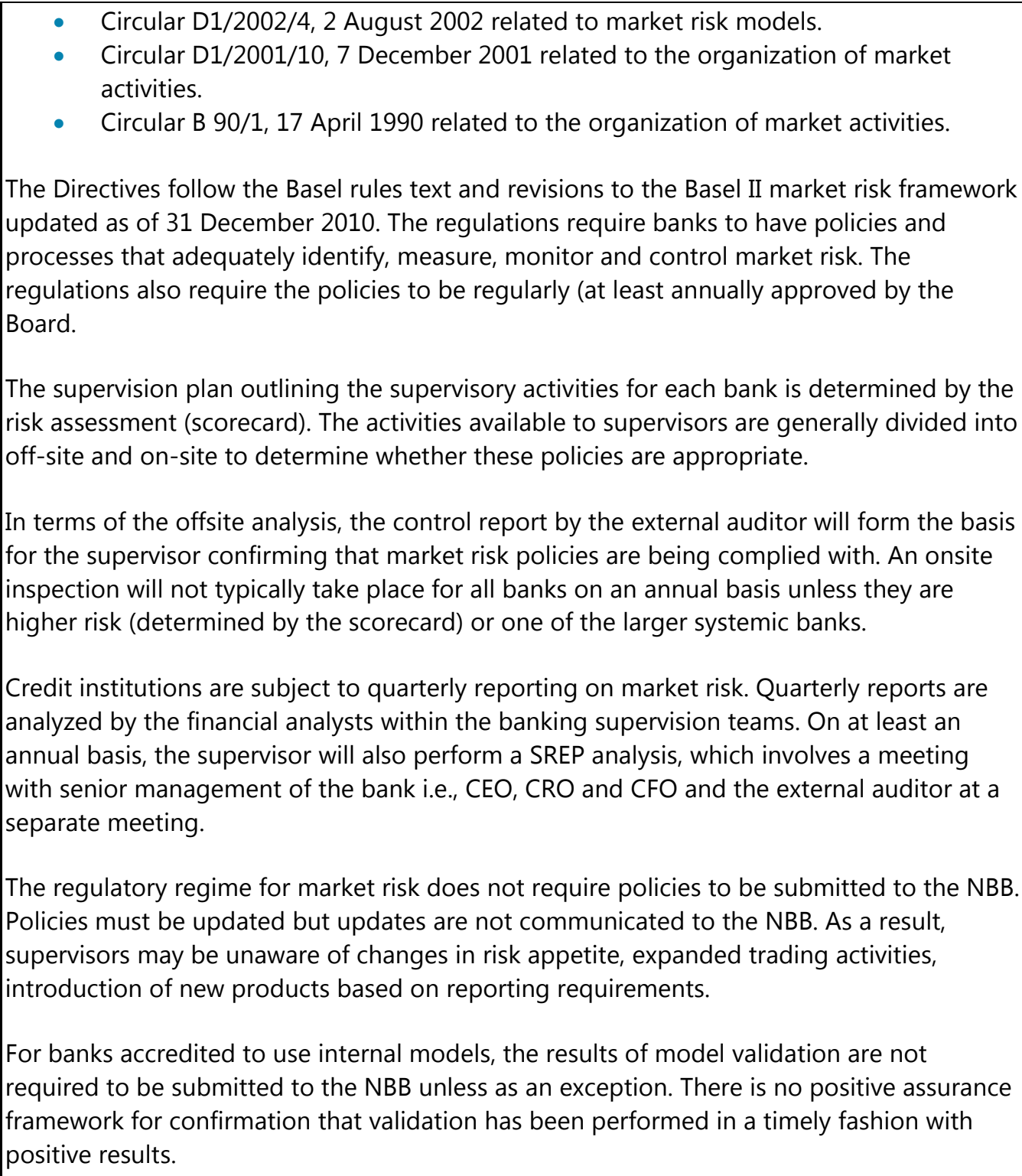 \\
\hline EC2 & $\begin{array}{l}\text { The supervisor determines that the bank has set market risk limits that are commensurate } \\
\text { with the institution's size and complexity and that reflect all material market risks. Limits } \\
\text { should be approved by the Board or senior management. The supervisor confirms that any } \\
\text { limits (either internal or imposed by the supervisor) are adhered to. }\end{array}$ \\
\hline $\begin{array}{l}\text { Description and } \\
\text { findings re EC2 }\end{array}$ & $\begin{array}{l}\text { The suite of market risk Circulars described in EC1 entail a number of requirements to } \\
\text { impose market risk limits on trading book activity. The most common market risk } \\
\text { measurement tool is Value-at-Risk (VaR) to limit positions. A weakness in the regulatory } \\
\text { framework is that there is no specified minimum for the period to calculate VaR. It appears } \\
\text { banks are using a range of minimum periods. The lack of consistent rule weakens the } \\
\text { ability of offsite analysis to compare and contrast peers and to identify outliers. } \\
\text { Typically Belgium credit institutions will develop limits based on sensitivities such as basis } \\
\text { point values (BPV) - global and per time bucket - or delta/vega's, liquidity limits, limits per } \\
\text { counterparty, stop loss limits, stress tests. While supervisors will perform periodic financial }\end{array}$ \\
\hline
\end{tabular}




\begin{tabular}{|c|c|}
\hline & $\begin{array}{l}\text { analysis (based on quarterly and annual submission), the main method employed by the } \\
\text { NBB to assess compliance with market risk limits is via onsite examinations. } \\
\text { The frequency of an onsite review is based on the output from the scorecard process, but } \\
\text { will be considered at least annually for banks with large or more complex portfolios and } \\
\text { trading strategies. The frequency of onsite reviews is considerably less than on an annual } \\
\text { basis for the majority of banks where the supervisory cycle would exceed one year. } \\
\text { The BCBS texts require Boards and senior management to approve market risk limits. The } \\
\text { current approach is to assess limit breaches as part of the annual SREP program. The } \\
\text { regulatory regime is not precise about the requirement for limit breaches to be reported } \\
\text { immediately to the NBB. The absence of this requirement combined with the potential for } \\
\text { fast pace of market volatility is a weakness and could inhibit the ability of the supervisor to } \\
\text { take prompt corrective action if required. It is recognized however, that traded markets } \\
\text { activity in the sector is not extensive and in run off for many banks. Nonetheless, at a time } \\
\text { when risk aversion abates, enhanced reporting of limit compliance, possibly quarterly, } \\
\text { could strengthen the early warning indicators supervisors receive. }\end{array}$ \\
\hline EC3 & $\begin{array}{l}\text { The supervisor is satisfied that there are systems and controls in place to ensure that all } \\
\text { transactions are captured on a timely basis, and that the banks' marked to market positions } \\
\text { are revalued frequently, using reliable and prudent market data (or, in the absence of } \\
\text { market prices, internal or industry-accepted models). The supervisor requires banks to } \\
\text { establish and maintain policies and processes for considering valuation } \\
\text { adjustments/reserves for positions that otherwise cannot be prudently valued, including } \\
\text { concentrated, less liquid, and stale positions. }\end{array}$ \\
\hline $\begin{array}{l}\text { Description and } \\
\text { findings re EC3 }\end{array}$ & $\begin{array}{l}\text { NBB Regulation 15/11/2011, Articles I.6 \& I.7 relates to ensuring rigorous and prudent } \\
\text { valuation practices by institutions. NBB's supervisory and audit teams are in charge of } \\
\text { verifying the compliance of institutions with these principles and the frequency of their } \\
\text { work will depend upon the output from the scorecard. } \\
\text { Off-site controls are mainly based on the analysis of the quarterly prudential reports } \\
\text { (COREP tables) as well as on institutions' internal risk reports, submitted annually. The } \\
\text { quarterly reporting forms the basis for interviews with institutions' market risk management } \\
\text { (frequency quarterly for larger banks and annually for all others). All credit institutions are } \\
\text { required to measure and report their trading book positions per instrument categories in } \\
\text { the prudential reporting on capital adequacy (COREP tables } 90.10 \text { to } 90.15 \text { ). } \\
\text { Onsite examinations are the main tool to assess the adequacy of bank policies and } \\
\text { processes for valuation adjustments on less liquid positions. The NBB will perform } \\
\text { interviews with banks to make the assessment. It is not clear on what information the NBB } \\
\text { will form a view about the appropriateness of valuations unless they receive a very detailed } \\
\text { report, which goes beyond the existing reporting requirements. There is evidence to } \\
\text { suggest that the NBB has acted to address valuations for Greek sovereign bonds in trading } \\
\text { portfolios, however, indicating that it is able and willing to examine emerging risks as they } \\
\text { are identified. } \\
\text { On-site assignments are performed in order to verify ongoing compliance with the } \\
\text { regulations and Circulars mentioned above. The scorecarding system is using an indicator } \\
\text { of materiality based on the ratio "notional amount of trading derivatives / balance sheet } \\
\text { total" and an indicator of riskiness based on the capital requirements for market risk. The }\end{array}$ \\
\hline
\end{tabular}




\begin{tabular}{|c|c|}
\hline & $\begin{array}{l}\text { quantitative indicators will not give any information about quality of risk management or } \\
\text { risk appetite. } \\
\text { Horizontal analysis is also performed by the specific market risk teams in order to identify } \\
\text { possible areas of concern. Liaison with the external auditor is a key component of reviewing } \\
\text { the valuation of mark to market positions and the accuracy of valuations. Like many banks } \\
\text { globally, the liquidity of market risk portfolios and therefore the valuation has been an } \\
\text { issue for Belgium banks. }\end{array}$ \\
\hline EC4 & $\begin{array}{l}\text { The supervisor determines that banks perform scenario analysis, stress testing and } \\
\text { contingency planning, as appropriate, and periodic validation or testing of the systems } \\
\text { used to measure market risk. The supervisor confirms that the approaches are integrated } \\
\text { into risk management policies and processes, and results are taken into account in the } \\
\text { bank's risk-taking strategy. }\end{array}$ \\
\hline $\begin{array}{l}\text { Description and } \\
\text { findings re EC4 }\end{array}$ & $\begin{array}{l}\text { Two Circulars set the requirements for periodic scenario analysis: NBB Regulation } \\
\text { 15/11/2011, articles IX.84 and IX.85; and Circular D1/2002/4, } 2 \text { August } 2002 \text { specifically } \\
\text { related to market risk models. The Circulars align with the EU Directive and the BCBS } \\
\text { recommendations, elements such as back testing, validation and stress testing in the } \\
\text { context of market risk internal models. The use test is also one criterion that is considered } \\
\text { when validating internal models. } \\
\text { The supervisory activity is less well defined and developed. In practice, a credit institution } \\
\text { with a moderate risk score will not require supervisory attention such as an onsite } \\
\text { examination to actively test effectiveness of the control environment by the supervisor. } \\
\text { Furthermore, it is not clear in the requirements that the results of stress testing and } \\
\text { scenario analysis needs to be submitted to the supervisor, or indeed if stress tests or } \\
\text { scenarios breach limits need to be reported to the supervisor. }\end{array}$ \\
\hline \multicolumn{2}{|l|}{$\begin{array}{l}\text { Additional } \\
\text { criteria }\end{array}$} \\
\hline AC1 & $\begin{array}{l}\text { The supervisor requires that market data used to value trading book positions are verified } \\
\text { by a function independent of the lines of business. To the extent that the bank relies on } \\
\text { modeling for the purposes of valuation, the bank is required to ensure that the model is } \\
\text { independently tested. }\end{array}$ \\
\hline $\begin{array}{l}\text { Description and } \\
\text { findings re } A C 1\end{array}$ & $\begin{array}{l}\text { NBB Regulation 15/11/2011, articles I.6 and I.7. In particular, article I.6 (b) determines that } \\
\text { internal control systems should ensure that information used to value trading book } \\
\text { positions is made independent from (and verified independently of) the dealing room. } \\
\text { Article I.7 § } 4 \text { specifies that the valuation model should be developed or approved by an } \\
\text { independent unit (i.e., independent from the dealing room). }\end{array}$ \\
\hline $\begin{array}{l}\text { Assessment of } \\
\text { Principle } 13\end{array}$ & Compliant \\
\hline Comments & $\begin{array}{l}\text { Consider implementing a number of additional early warning indicators for market risk to } \\
\text { complement existing market risk measurement tools, mainly VaR. Measures might include } \\
\text { risk tolerances across a number of market risk metrics and clearly linked to a risk appetite } \\
\text { statement. Other tools to identify changes in risk might include notification of new product } \\
\text { approvals. }\end{array}$ \\
\hline
\end{tabular}




\begin{tabular}{|c|c|}
\hline Principle 14 & $\begin{array}{l}\text { Liquidity risk. Supervisors must be satisfied that banks have a liquidity management } \\
\text { strategy that takes into account the risk profile of the institution, with prudent policies and } \\
\text { processes to identify, measure, monitor and control liquidity risk, and to manage liquidity } \\
\text { on a day-to-day basis. Supervisors require banks to have contingency plans for handling } \\
\text { liquidity problems. }\end{array}$ \\
\hline Essential criteria & \\
\hline EC1 & $\begin{array}{l}\text { The supervisor sets liquidity guidelines for banks. These guidelines take into consideration } \\
\text { undrawn commitments and other off-balance sheet liabilities, as well as existing on- } \\
\text { balance sheet liabilities. }\end{array}$ \\
\hline $\begin{array}{l}\text { Description and } \\
\text { findings re EC1 }\end{array}$ & 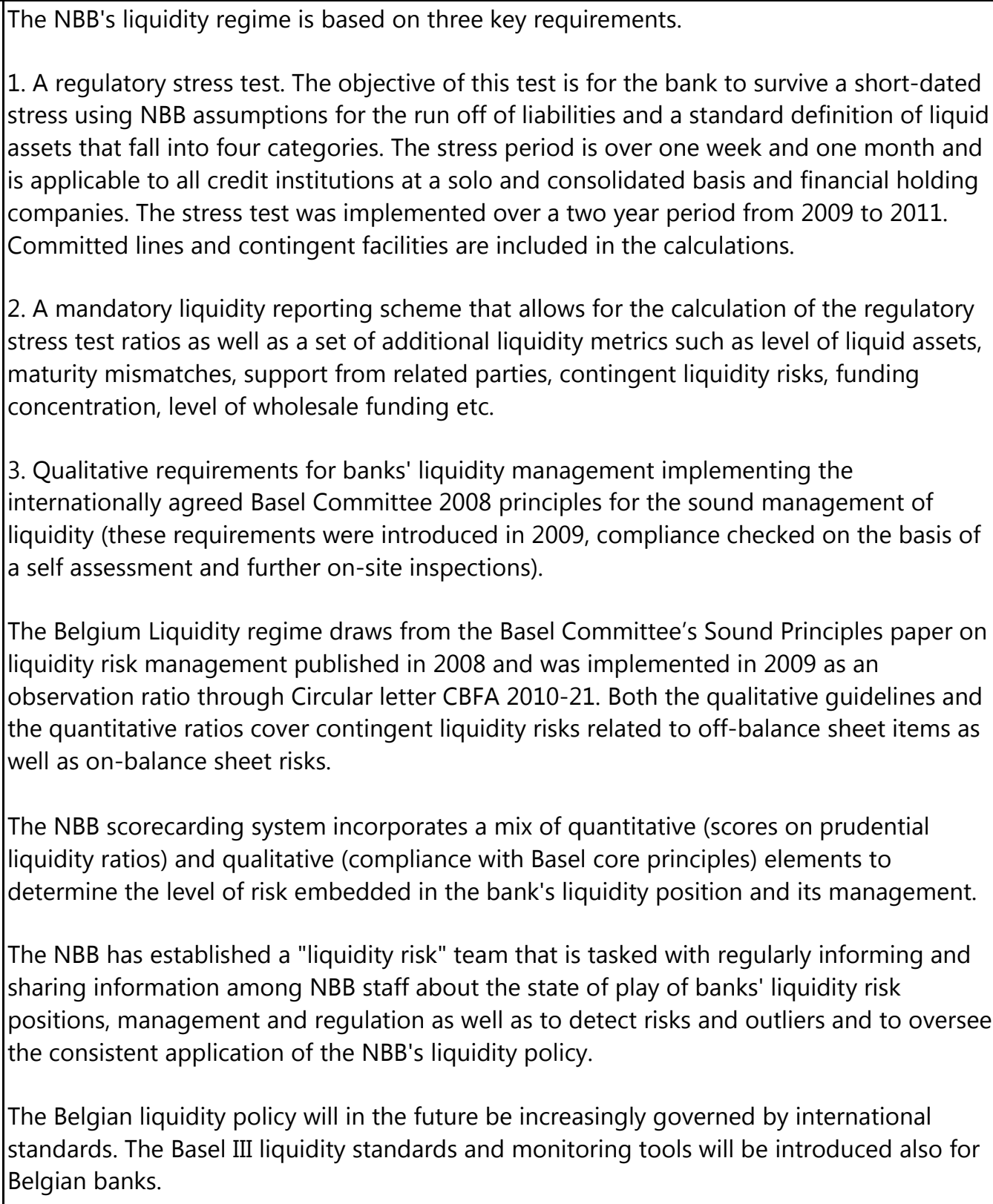 \\
\hline
\end{tabular}




\begin{tabular}{|c|c|}
\hline & $\begin{array}{l}\text { The NBB monitors the liquidity position of major banks on a daily basis through } \\
\text { management information and calls with banks' treasurers. The NBB has in place daily } \\
\text { liquidity reporting for the larger systemically important credit institutions. This is a mix of } \\
\text { top down qualitative information from those in the markets area of the NBB and bottom } \\
\text { up bank specific information. } \\
\text { Since 2006, the NBB has organized and conducted annual liquidity stress test exercises and } \\
\text { high level meetings on liquidity risk with the major banks. The } 2011 \text { liquidity (stress-test) } \\
\text { exercise focused on three main areas: } 1 \text { ) developments in the Belgian regulatory stress test } \\
\text { ratio for liquidity risk and other indicators of liquidity risk calculated by the NBB based on } \\
\text { prudential reporting; and 2) the results of the QIS on Basel III liquidity standards and 3) the } \\
\text { internal liquidity stress tests of banks. At the end of the exercise, the NBB produces a } \\
\text { feedback note analyzing each bank's results and comparing them with their peers. } \\
\text { The regulatory stress test allows intra-group support to meet the test and there is no limit } \\
\text { as to the extent of intra-group support. The implication being that in extremis, credit } \\
\text { institutions within a group would not have to hold a minimum level of own-liquidity (on its } \\
\text { own balance sheet) to meet the test. Furthermore, the group providing the liquidity is not } \\
\text { assumed to be under stress, which assumes no contagion and fungible excess liquidity at } \\
\text { the parent. The assumption of unlimited intra-group support means the stress is not a } \\
\text { stand-alone test of a credit institution. } \\
\text { The other observation regarding the stress test is that credit institutions only need to meet } \\
\text { the test on an aggregate basis and not across individual currencies in the liabilities } \\
\text { schedule. }\end{array}$ \\
\hline EC2 & $\begin{array}{l}\text { The supervisor confirms that banks have a liquidity management strategy, as well as } \\
\text { policies and processes for managing liquidity risk, which have been approved by the Board. } \\
\text { The supervisor also confirms that the Board has an oversight role in ensuring that policies } \\
\text { and processes for risk-taking are developed to monitor, control and limit liquidity risk, and } \\
\text { that management effectively implements such policies and processes. }\end{array}$ \\
\hline $\begin{array}{l}\text { Description and } \\
\text { findings re EC2 }\end{array}$ & $\begin{array}{l}\text { The minimum expectations of the NBB in regards to a liquidity policy framework are } \\
\text { described in the BCBS Sound Principles - specifically Principle } 3 \text {. The liquidity regime } \\
\text { requires banks to develop a strategy, policies and practices to manage liquidity risk and to } \\
\text { ensure that the bank maintains sufficient liquidity and for the board of directors to review } \\
\text { and approve these at least annually. } \\
\text { The supervisory activity to confirm that banks have effectively implemented such policies } \\
\text { and processes will be the qualitative requirement. The qualitative requirements apply to all } \\
\text { credit institutions. When the BCBS document was introduced all institutions performed a } \\
\text { self assessment against the principles in the document. The outcome of the assessment } \\
\text { was entered into the scorecard creating a risk-based assessment of liquidity risk } \\
\text { management. The ongoing evaluation of the effectiveness of risk management for liquidity } \\
\text { is focusing on specific requirements such as stress tests, governance, monitoring systems, } \\
\text { reporting, intra-group relations etc. rather than a fully-fledged assessment of the full } \\
\text { spectrum of BCBS requirements for all banks. More attention is paid to the liquidity } \\
\text { management in banks that exhibit less robust liquidity positions. }\end{array}$ \\
\hline
\end{tabular}




\begin{tabular}{|c|c|}
\hline EC3 & $\begin{array}{l}\text { The supervisor determines that a bank's senior management has defined (or established) } \\
\text { appropriate policies and processes to monitor, control and limit liquidity risk; implements } \\
\text { effectively such policies and processes; and understands the nature and level of liquidity } \\
\text { risk being taken by the bank. }\end{array}$ \\
\hline $\begin{array}{l}\text { Description and } \\
\text { findings re EC3 }\end{array}$ & $\begin{array}{l}\text { The regulatory regime requires a bank's senior management to develop policies and } \\
\text { practices to manage liquidity risk articulated in principle } 5 \text { of the BCBS document adopted } \\
\text { by the NBB. The main means of confirming that the policies and practices are implemented } \\
\text { effectively is the annual internal control report, the external audit reports, and the annual } \\
\text { meeting with credit institutions. Onsite examinations will be performed where required. }\end{array}$ \\
\hline EC4 & $\begin{array}{l}\text { The supervisor requires banks to establish policies and processes for the ongoing } \\
\text { measurement and monitoring of net funding requirements. The policies and processes } \\
\text { include considering how other risks (e.g., credit, market and operational risk) may impact } \\
\text { the bank's overall liquidity strategy, and require an analysis of funding requirements under } \\
\text { alternative scenarios, diversification of funding sources, a review of concentration limits, } \\
\text { stress testing, and a frequent review of underlying assumptions to determine that they } \\
\text { continue to be valid. }\end{array}$ \\
\hline $\begin{array}{l}\text { Description and } \\
\text { findings re } E C 4\end{array}$ & $\begin{array}{l}\text { The BCBS Principles for Sound Liquidity Risk Management sets out the requirements to } \\
\text { satisfy this criterion. Principle } 5 \text { of this document requires banks to have a sound process } \\
\text { for identifying, measuring, monitoring and controlling liquidity risk. Principle } 6 \text { requires } \\
\text { credit institutions to monitor and control liquidity across legal entities, business lines and } \\
\text { currencies taking into account limitations to the transferability of liquidity. The regulatory } \\
\text { framework is clear regarding policies and processes. } \\
\text { While Principle } 6 \text { requires the establishment of a funding strategy that provides for } \\
\text { effective diversification the fact that the regulatory stress test does not limit the extent of } \\
\text { intra-group support to meet the outflow of funds is contrary to the diversification principle. } \\
\text { The NBB regulatory stress test ratios for liquidity risk compare the potentially required } \\
\text { liquidity (net stressed outflows calculated as the sum of the stressed mismatch and a } \\
\text { percentage of the bank's contingent claims) with the liquidity available to the bank } \\
\text { (calculated as the liquidity buffer composed of unencumbered liquid assets and the } \\
\text { potential support from related parties) for a one week and one month horizon, both on a } \\
\text { consolidated and a legal entity basis. The ratio actually uses the same methodology as the } \\
\text { forthcoming Basel III Liquidity Coverage Ratio but includes different parameters and } \\
\text { definitions. } \\
\text { These ratios were used as internal measures until the financial crisis, introduced as non- } \\
\text { binding observation ratios in } 2009 \text { and as binding regulatory standards since the beginning } \\
\text { of } 2011 \text {. A ratio higher than } 100 \text { percent implies a liquidity shortage if the stress scenario } \\
\text { would materialize at the reporting date (potentially required liquidity > potentially available } \\
\text { liquidity). The assumptions do allow some less stringent ideas: full convertibility between } \\
\text { currencies (within a time frame of one week). } \\
\text { The Belgian liquidity standard, compared to the LCR, is generally less severe with regard to } \\
\text { the definition of the liquidity buffer, but this is compensated by stricter assumptions on the } \\
\text { stress scenario and liquidity outflows. }\end{array}$ \\
\hline
\end{tabular}




\begin{tabular}{|c|c|}
\hline EC5 & $\begin{array}{l}\text { The supervisor obtains sufficient information to identify those institutions carrying out } \\
\text { significant foreign currency liquidity transformation. Where a bank or banking group's } \\
\text { foreign currency business, either directly, or indirectly through lending in foreign exchange } \\
\text { to domestic borrowers, is significant, or where a particular currency in which the bank has } \\
\text { material exposure is experiencing problems, the supervisor requires the bank to undertake } \\
\text { separate analysis of its strategy for each currency individually and, where appropriate, set } \\
\text { and regularly review limits on the size of its cash flow mismatches for foreign currencies in } \\
\text { aggregate and for each significant individual currency. }\end{array}$ \\
\hline & $\begin{array}{l}\text { The liquidity reporting scheme is reported separately for the position in EUR, the aggregate } \\
\text { position in convertible currencies (G-10 + EU countries' official currencies) and individual } \\
\text { positions in non-convertible currencies. Separate reporting of the position in convertible } \\
\text { currencies (mainly USD positions) is only delivered by the major banks. } \\
\text { In the context of the monitoring of the Basel III Liquidity Coverage Ratio the NBB require } \\
\text { banks to fill in LCR templates in USD if their positions are significant. For banks that } \\
\text { maintain significant positions Principle } 5 \text { of the qualitative requirements (Basel principles) } \\
\text { determines that a bank should assess its foreign currency needs, determine acceptable } \\
\text { mismatches, be capable to manage risk arising from foreign currency deposits and foreign } \\
\text { currency assets funded in domestic currency and develop contingency strategies. } \\
\text { Belgian banks submit a standardized liquidity reporting scheme (tables } 90.31-33 \text { ) to the } \\
\text { NBB on a monthly basis. The reporting tables incorporate information on the } \\
\text { unencumbered liquid assets, projected in- and outflows, contingent liquidity risks etc. of } \\
\text { the firm. Reporting is submitted both on a entity level as well as the consolidated level. } \\
\text { The Bank Performance Report (BPR) calculates a number of prudential liquidity metrics on } \\
\text { the basis of this input. These ratios are complemented with data on funding concentration } \\
\text { and the standing in debt markets (short term credit ratings) of firms to determine the } \\
\text { quantitative elements of the institution's score for liquidity risk. } \\
\text { Horizontal analysis will assess potential outliers for these ratios in order to signal potential } \\
\text { outliers to the operational supervisors and the NBB's hierarchy. This analysis is incorporated } \\
\text { in a quarterly liquidity and funding review that is presented to the NBB Board. } \\
\text { The NBB also receives the major banks' liquidity management info daily on the basis of } \\
\text { which the following standard liquidity dashboard is edited and distributed within the NBB: } \\
\text { Not all banks are required to test their liquidity by currency and to ensure sufficient } \\
\text { diversification of their funding sources by currency. }\end{array}$ \\
\hline EC6 & $\begin{array}{l}\text { The supervisor determines that banks have contingency plans in place for handling liquidity } \\
\text { problems, including informing the supervisor. }\end{array}$ \\
\hline $\begin{array}{l}\text { Description and } \\
\text { findings re EC6 }\end{array}$ & $\begin{array}{l}\text { Principle } 11 \text { of the Sound Principles requires banks to have a formal contingency funding } \\
\text { plan that clearly sets out the strategies for addressing liquidity shortfalls in emergency } \\
\text { situations. These plans have been effectively activated by a number of institutions during } \\
\text { the last few years. At the introduction of the revised qualitative requirements in } 2009, \\
\text { compliance was checked on the basis of a self assessment and an implementation plan } \\
\text { generated by the banks. On-site inspections were conducted at a selected number of } \\
\text { individual institutions, including all large banks, to check compliance, though not across all }\end{array}$ \\
\hline
\end{tabular}




\begin{tabular}{|c|c|}
\hline & $\begin{array}{l}\text { credit institutions and investment firms were not included. Contingency funding plans are } \\
\text { not required to be submitted or vetted by the NBB on an ongoing basis. } \\
\text { While all credit institutions were required to complete a self assessment against the sounds } \\
\text { principles upon introduction, fully-fledged inspections were not carried out across the } \\
\text { broader population of banks. Dedicated deep dive inspections into banks identified as } \\
\text { outliers are however conducted. Nevertheless, since the self assessment exercise, no } \\
\text { indication that the NBB intends to carry out of a systematic follow up to monitor how } \\
\text { banks are progressing, especially if significant remedial action required. } \\
\text { The NBB's liquidity reporting scheme and ratios cover position in euro, the aggregate of } \\
\text { convertible currencies and important positions in individual non-convertible currencies } \\
\text { (virtually non-existing). If foreign currency funding risks are relevant to the bank's business } \\
\text { the NBB's qualitative guidelines require banks to assess currency mismatches (see } \\
\text { standards' assessment), foresee contingency measures and analyze the issue non- } \\
\text { convertibility of currencies in their stress testing. } \\
\text { The issue of foreign currency risk is included the annual stress testing exercise but the NBB } \\
\text { does not require banks to perform individual stress tests for specific currencies. The new } \\
\text { European Basel III LCR stress test reporting that will be introduced from next year onwards } \\
\text { will complement the NBB reporting scheme and will require each bank to report in each } \\
\text { currency in which the bank has a significant position. }\end{array}$ \\
\hline \multicolumn{2}{|l|}{$\begin{array}{l}\begin{array}{l}\text { Additional } \\
\text { criteria }\end{array} \\
\end{array}$} \\
\hline $\mathrm{AC1}$ & $\begin{array}{l}\text { The supervisor determines that, where a bank conducts its business in multiple currencies, } \\
\text { foreign currency liquidity strategy is separately stress-tested, and the results of such tests } \\
\text { are a factor in determining the appropriateness of mismatches. }\end{array}$ \\
\hline $\begin{array}{l}\text { Description and } \\
\text { findings re } A C 1\end{array}$ & $\begin{array}{l}\text { Principle } 5 \text { of the Sound Principles sets out the requirements for a bank to assess its foreign } \\
\text { currency needs and determine acceptable mismatches. Principle } 9 \text { on stress testing requires } \\
\text { banks to include the issue of FX convertibility and access to foreign exchange markets in its } \\
\text { tests if relevant to its business. }\end{array}$ \\
\hline AC2 & $\begin{array}{l}\text { The supervisor confirms that banks periodically review their efforts to establish and } \\
\text { maintain relationships with liability holders, maintain the diversification of liabilities, and } \\
\text { aim to ensure their capacity to sell assets. }\end{array}$ \\
\hline $\begin{array}{l}\text { Description and } \\
\text { findings re } A C 2\end{array}$ & $\begin{array}{l}\text { The NBB adopted the Basel Committee's September } 2008 \text { Principles for Sound Liquidity } \\
\text { Risk Management as its set of qualitative guidelines according to which it expects banks to } \\
\text { govern their liquidity risk management. Principle } 7 \text { of these requirements refers to funding } \\
\text { diversification and to the maintenance of market access as an essential component of } \\
\text { ensuring funding diversity. A bank is requested to build strong relationships with current } \\
\text { and potential investors, develop markets for assets sales and strengthen arrangements } \\
\text { under which it can borrow secured or unsecured. }\end{array}$ \\
\hline
\end{tabular}




\begin{tabular}{|c|c|}
\hline $\begin{array}{l}\text { Assessment of } \\
\text { Principle } 14\end{array}$ & Compliant \\
\hline Comments & $\begin{array}{l}\text { The regulatory requirements for liquidity risk are well advanced with a quantitative test } \\
\text { similar to the Basel LCR in place since } 2011 \text {. Daily reporting for larger systemic banks } \\
\text { robust. } \\
\text { Consider applying certain limitations to either the timing or the extent to which intra-group } \\
\text { support can meet the regulatory stress test. This will strengthen the individual liquidity } \\
\text { position of a bank. }\end{array}$ \\
\hline Principle 15 & $\begin{array}{l}\text { Operational risk. Supervisors must be satisfied that banks have in place risk management } \\
\text { policies and processes to identify, assess, monitor and control/mitigate operational risk. } \\
\text { These policies and processes should be commensurate with the size and complexity of the } \\
\text { bank. }\end{array}$ \\
\hline \multicolumn{2}{|r|}{ ( } \\
\hline EC1 & $\begin{array}{l}\text { The supervisor requires individual banks to have in place risk management policies and } \\
\text { processes to identify, assess, monitor and mitigate operational risk. These policies and } \\
\text { processes are adequate for the size and complexity of the bank's operations, and the } \\
\text { supervisor confirms that they are periodically adjusted in the light of the bank's changing } \\
\text { risk profile and external market developments. }\end{array}$ \\
\hline $\begin{array}{l}\text { Description and } \\
\text { findings re } E C 1\end{array}$ & $\begin{array}{l}\text { Articles } 20,46 \text { and } 43 \text { of the Banking Law set the regulatory framework for operational risk. } \\
\text { Article } 43 \text { forms the basis for the NBB Regulation of } 15 \text { November } 2011 \text { on the capital of } \\
\text { credit institutions and investment firms, which includes Pillar } 1 \text { and Pillar } 2 \text { requirements for } \\
\text { operational risk and other risk categories. Title VIII of the NBB Capital regulation lays down } \\
\text { the Pillar } 1 \text { capital requirements for operational risk. Title XII holds the Pillar } 2 \text { ICAAP and } \\
\text { SREP regulation (including for operational risk). The NBB Capital regulation mirrors the } \\
\text { European CRD/CAD Directives, which are largely consistent with the Basel Capital Accord. } \\
\text { NBB's Communication NBB_2011_05 of } 27 \text { October } 2011 \text { formally advised banks that the } \\
\text { BCBS Principles for the Sound Management of Operational Risk of June } 2011 \text { set new } \\
\text { prudential expectations and that these principles will be used when assessing a bank's } \\
\text { operational risk management. } \\
\text { Qualitative criteria prescribed by the NBB Regulation of } 15 \text { November } 2011 \text { on the capital } \\
\text { of credit institutions and investment firms (and by the guidelines to that Regulation) for } \\
\text { banks using the Standardized Approach or the Advanced Measurement Approach, imposes } \\
\text { additional and specific requirements regarding these elements, mainly based on EBA/CEBS } \\
\text { guideline. } \\
\text { The NBB has issued a number of specific Circulars regarding components of operational } \\
\text { risk such as sound management of outsourcing, of business continuity planning and of } \\
\text { financial services providing via the internet. Additional recommendations regarding } \\
\text { business continuity management for systematically important institutions were issued by } \\
\text { the Committee for Financial Stability on October } 20 \text { th, } 2004 \text {. } \\
\text { On and off-site supervision of operational risk at individual banks is performed by the } \\
\text { supervisor and, specifically for information technology aspects and for mathematical model } \\
\text { validations, by the risk specialist teams. Under the umbrella of the Risk Committee, a }\end{array}$ \\
\hline
\end{tabular}




\begin{tabular}{|c|c|}
\hline & $\begin{array}{l}\text { dedicated "Operational Risk Team" has been established providing a structured forum for } \\
\text { regular information sharing between those different departments, for dealing with possible } \\
\text { level playing field considerations, etc. } \\
\text { A separate committee (OCCO) monitors the implementation of the additional } \\
\text { recommendations issued on October 20th, } 2004 \text { regarding business continuity } \\
\text { management by the systematically important institutions. Operational risk is a dedicated } \\
\text { risk category in the overall periodic scorecard. } \\
\text { The NBB requires banks to put in place a comprehensive operational risk management } \\
\text { framework through the application of the BCBS Sound Principles. The provisions of the } \\
\text { Circular are applied on a proportional basis by the NBB depending upon the risk profile } \\
\text { through the scorecard. Relevant changes in risk profile have to be reported to the NBB in } \\
\text { effective management reports on internal controls as prescribed by Circular letter } 2011 \text {-09 } \\
\text { of } 20 \text { December 2009. } \\
\text { The quarterly reporting for operational risk for those credit institutions using the basic } \\
\text { indicator and Standardized approach does not have a level of granularity that would } \\
\text { identify changes in risk profile. } \\
\text { A new supervisory process has been added for the larger credit institutions to submit to } \\
\text { the NBB a new product approval document, which appears to be a good tool in } \\
\text { periodically assessing the risk management framework as it applies to new lines of } \\
\text { business. While the new product approval document is available to the NBB, there is no } \\
\text { requirement to be submitted to the NBB. }\end{array}$ \\
\hline EC2 & $\begin{array}{l}\text { The supervisor requires that banks' strategies, policies and processes for the management } \\
\text { of operational risk have been approved and are periodically reviewed by the Board. The } \\
\text { supervisor also requires that the Board oversees management in ensuring that these } \\
\text { policies and processes are implemented effectively. }\end{array}$ \\
\hline $\begin{array}{l}\text { Description and } \\
\text { findings re EC2 }\end{array}$ & $\begin{array}{l}\text { The BCBS document explicitly refers to the role of the Board of directors in approving } \\
\text { policies for operational risk (Principles } 1,3 \& 4 \text { ). As a Pillar } 1 \text { risk and part of the risk } \\
\text { scorecard, operational risk will be assessed at least annually by the supervisor as part of the } \\
\text { SREP. For higher risk banks, operational risk might be assessed on a more regular basis on } \\
\text { a case by case basis. The principle tools used by banks for identifying and assessing } \\
\text { operational risks are: } \\
\text { i) descriptions of business processes with their key risks and key controls } \\
\text { ii) periodic self assessments (e.g., scenarios) } \\
\text { iii) loss data registration (including performing a "lessons learned" analysis) } \\
\text { iv) testing/monitoring the operational effectiveness of the key controls } \\
\text { v) internal risk reporting. } \\
\text { These tools serve as an input for the effective management's reports on internal controls. }\end{array}$ \\
\hline
\end{tabular}




\begin{tabular}{|c|c|}
\hline & $\begin{array}{l}\text { EC2 requires Board oversight of operational risk and that the policies and processes have } \\
\text { been approved by the Board and vetted by senior management. It is expected that there } \\
\text { would be a review and approval of operational risk management policies by Board at least } \\
\text { annually (and more frequently if the environment or business is changing). } \\
\text { While the regulatory framework requires Board oversight, it is not a requirement that } \\
\text { policies are submitted to the NBB on an annual basis. }\end{array}$ \\
\hline EC3 & $\begin{array}{l}\text { The supervisor is satisfied that the approved strategy and significant policies and processes } \\
\text { for operational risk are implemented effectively by management. }\end{array}$ \\
\hline $\begin{array}{l}\text { Description and } \\
\text { findings re EC3 }\end{array}$ & 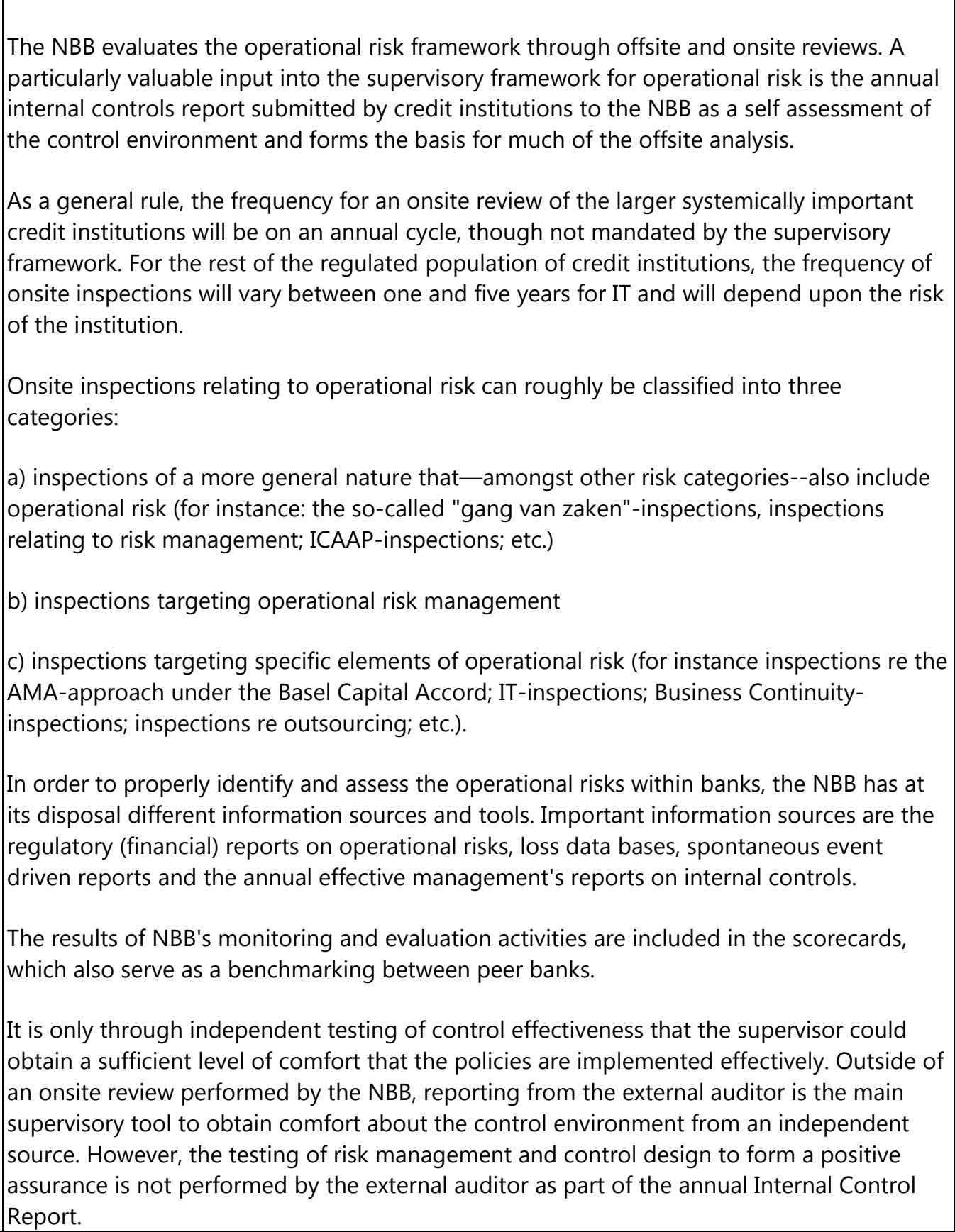 \\
\hline
\end{tabular}




\begin{tabular}{|c|c|}
\hline & $\begin{array}{l}\text { An onsite review must be performed periodically to derive comfort that implementation is } \\
\text { effective. The frequency would be determined by the risk profile using other evidence such } \\
\text { as discussions with senior management, BPR etc. }\end{array}$ \\
\hline EC4 & $\begin{array}{l}\text { The supervisor reviews the quality and comprehensiveness of the bank's business } \\
\text { resumption and contingency plans to satisfy itself that the bank is able to operate as a } \\
\text { going concern and minimise losses, including those that may arise from disturbances to } \\
\text { payment and settlement systems, in the event of severe business disruption. }\end{array}$ \\
\hline $\begin{array}{l}\text { Description and } \\
\text { findings re EC4 }\end{array}$ & $\begin{array}{l}\text { The NBB requirements for business continuity are captured in the BCBS principles (in } \\
\text { particular Principle } 10 \text { regarding business resilience and continuity). In addition, a } \\
\text { dedicated Circular letter PPB 2005/2 of } 10 \text { March 2005, provides guidance on sound } \\
\text { business continuity management practices. } \\
\text { An assessment of the adequacy of the business resumption and contingency plans is } \\
\text { included in the standard onsite examination. } \\
\text { The supervisory process for the larger systemic credit institutions appears to be relatively } \\
\text { well established, however, the processes for the wider population of banks is less } \\
\text { established. While all credit institutions are required to perform regular BCP and DR testing, } \\
\text { the NBB will not necessarily receive the results of that testing. Should a credit institution fail } \\
\text { its own test or the test identifies certain weaknesses, there is no requirement that the NBB } \\
\text { be notified. }\end{array}$ \\
\hline EC5 & $\begin{array}{l}\text { The supervisor determines that banks have established appropriate information technology } \\
\text { policies and processes that address areas such as information security and system } \\
\text { development, and have made investments in information technology commensurate with } \\
\text { the size and complexity of operations. }\end{array}$ \\
\hline $\begin{array}{l}\text { Description and } \\
\text { findings re EC5 }\end{array}$ & $\begin{array}{l}\text { EC5 is seeking to determine the extent of specific IT requirements in the operational risk } \\
\text { regulations. IT is critical to banking operations and as such reliable and stable IT is an } \\
\text { important contributor to financial stability. Given its importance specific requirements by } \\
\text { the NBB have been put in place in addition to the more general operational risk } \\
\text { requirements. } \\
\text { The BCBS principles (in particular principle } 9, \S \S 47 \text { to 53) cover elements of IT. In addition, } \\
\text { the dedicated Circular letter PPB } 2005 / 2 \text { of } 10 \text { March } 2005 \text { of the CBFA providing guidance } \\
\text { on sound business continuity management practices includes specific ICT-related guidance. } \\
\text { A dedicated Circular letter CBFA_2009_17 of } 9 \text { April } 2009 \text { contains the NBB's prudential } \\
\text { expectations relating to the provision of financial services via the Internet. These } \\
\text { expectations refer to legal risks, operational risks and reputational risks, and include } \\
\text { aspects such as management responsibility, contractual relationships, security, availability, } \\
\text { continuity, outsourcing, client identification, an attachment to that Circular letter provides } \\
\text { specific sound practices relating to the management of Internet security risks and are } \\
\text { presented to banks according to the "comply or explain" principle. } \\
\text { Onsite examinations are critical for EC5. The NBB has a team of eight IT risk specialists, } \\
\text { which cover approximately } 170 \text { firms regulated by the NBB. It is challenging for this small } \\
\text { team to cover the regulated population. The NBB uses the risk scorecard to help identify } \\
\text { higher risk banks, critical to directing scarce resources to the highest risk banks. This places }\end{array}$ \\
\hline
\end{tabular}




\begin{tabular}{|c|c|}
\hline & a high reliance on the effectiveness of the risk scorecard to identify at risk banks. \\
\hline EC6 & $\begin{array}{l}\text { The supervisor requires that appropriate reporting mechanisms are in place to keep the } \\
\text { supervisor apprised of developments affecting operational risk at banks in their } \\
\text { jurisdictions. }\end{array}$ \\
\hline $\begin{array}{l}\text { Description and } \\
\text { findings re EC6 }\end{array}$ & $\begin{array}{l}\text { EC6 requires appropriate reporting to the authorities of operational risk metrics. The BCBS } \\
\text { Principles (in particular principle } 8 \text { ) covers some elements of this criterion. Important } \\
\text { sources of information for the NBB are the effective management reports on internal } \\
\text { controls (Circular letter NBB_2011_09 of } 20 \text { December 2011) that have to be transmitted to } \\
\text { the NBB annually by all credit institutions. } \\
\text { The legal framework requiring strategic decisions (including those regarding operational } \\
\text { risk) to be submitted to the NBB, is also a useful tool. In addition, the NBB receives the } \\
\text { following reporting: } \\
\text { in a quarterly table (90.16) all banks report their operational risk capital } \\
\text { requirement calculations } \\
\quad \text { in a yearly table (90.17) all AMA banks report their past year's operational risk } \\
\quad \text { losses } \\
\quad \text { banks have to report spontaneously events such as major frauds or suspect } \\
\text { operations regarding market-risk related activities (Circular letter NBB_2012_03 of } \\
\quad \text { in May 2012), any security incidents Internet services or IT infrastructure security } \\
\text { incidents (Circular letter CBFA_2009_17 of } 9 \text { April 2009) and material outsourcing } \\
\text { arrangements (Circular letter PPB 2004/5 of } 22 \text { June 2004).. } \\
\text { Furthermore, Circular letter CBFA_2009_19 of } 8 \text { May } 2009 \text { (relating to the mission of a } \\
\text { bank's external auditor as co-operator to prudential supervision) holds specific reporting } \\
\text { tasks (see Section F re information exchange) requesting the external auditor to } \\
\text { communicate certain events spontaneously (some of which may be operational risk related) } \\
\text { to the NBB. }\end{array}$ \\
\hline EC7 & $\begin{array}{l}\text { The supervisor confirms that legal risk is incorporated into the operational risk } \\
\text { management processes of the bank. }\end{array}$ \\
\hline $\begin{array}{l}\text { Description and } \\
\text { findings re EC7 }\end{array}$ & $\begin{array}{l}\text { EC7 requires explicit consideration of legal risk as part of the operational risk management } \\
\text { process. There is no explicit reference to legal risk in the BCBS document. This is a } \\
\text { deficiency in the operational risk framework. }\end{array}$ \\
\hline EC8 & $\begin{array}{l}\text { The supervisor determines that banks have established appropriate policies and processes } \\
\text { to assess, manage and monitor outsourced activities. The outsourcing risk management } \\
\text { programme should cover: } \\
\text { - conducting appropriate due diligence for selecting potential service providers; } \\
\text { - } \quad \text { structuring the outsourcing arrangement; } \\
\text { - ensuring an effective control environment; and } \\
\text { Outsourcing policies and processes should require the institution to have comprehensive } \\
\text { contracts and/or service level agreements with a clear allocation of responsibilities between } \\
\text { the outsourcing provider and the bank. }\end{array}$ \\
\hline
\end{tabular}




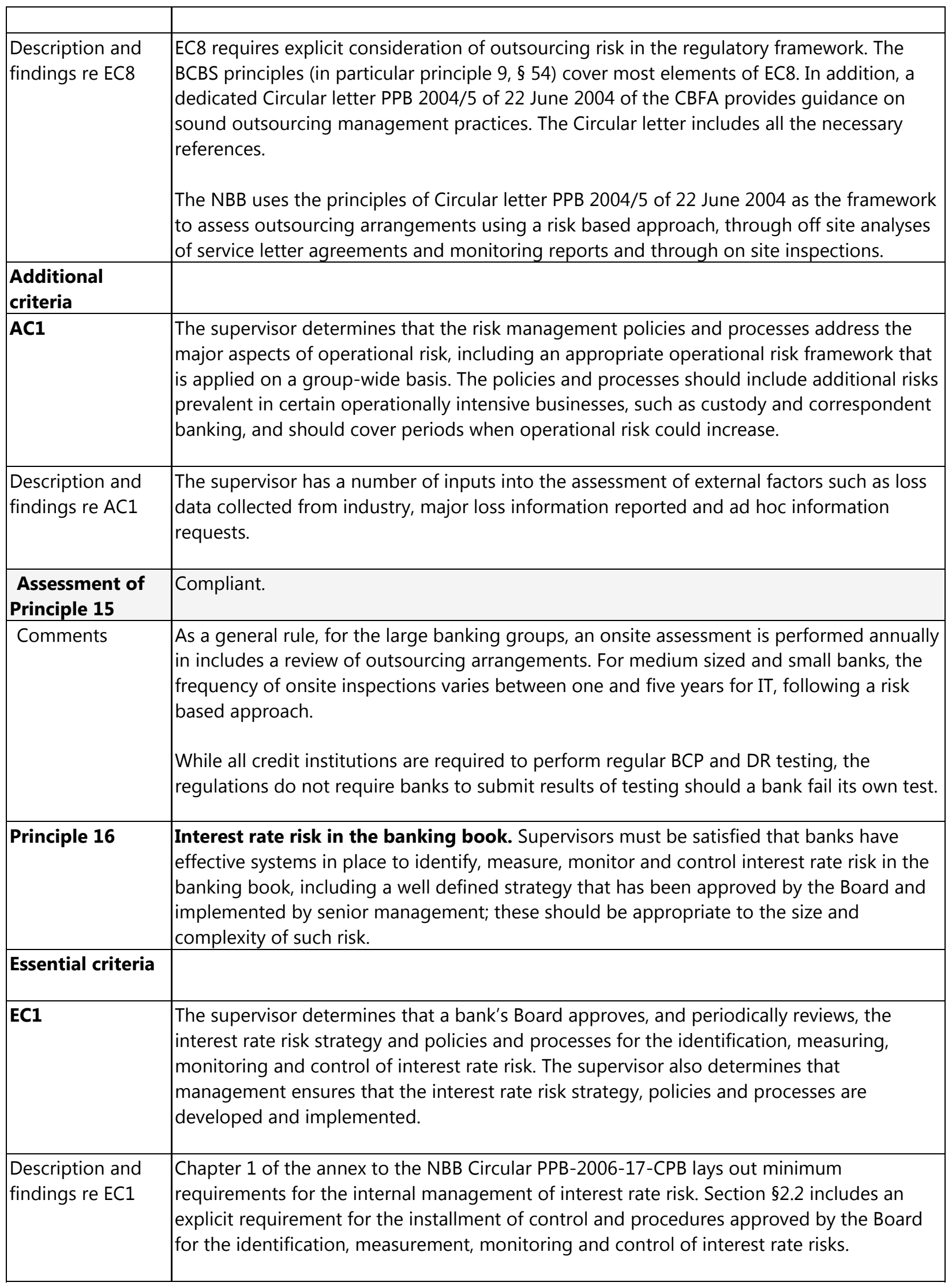


The Circular also requires internal risk limits and an internal control system to be developed in accordance with the strength of the institution and that there should be sufficient flows of information with the supervisor. The Circular requires the Board to be involved in determining strategies and approving all important policies, as well as the effective supervision of the implementation.

The regulatory framework requires involvement of the Board in setting policies and processes. The NBB guidelines are strongly aligned with the relevant international texts of $B C B S$ and CEBS/EBA.

The Circular treats both qualitative aspects (adequacy of internal risk management and risk measurement systems) and quantitative aspects, in line with the international rules and guidance (BCBS \& CEBS). The Circular explicitly references the two documents as the basis of the NBB's expectations. These texts are quasi completely aligned with each other and at its turn. The circular incorporates them into the Belgian, which provides for a flexible way to pick up progress made at the EBA and the likely developments in the banking union. The NBB's IRRBB regime has two main features:

1. Regulatory IRRBB stress test ratios requiring banks to hold sufficient capital to cover economic value losses related to adverse structural interest rate changes in order not to be identified as an outlier bank..

2. Qualitative requirements for banks' IRRBB management implementing the internationally agreed Basel Committee 2004 principles for the management and supervision of interest rate risk, and implementing the CEBS 2006 "Technical aspects of the management of interest rate risk arising from non-trading activities under the supervisory review process."

The NBB organizes annual IRRBB stress test exercises as part of the European solvency stress tests, which integrate both interest rate risk and spread scenarios.

The NBB scorecarding system incorporates a mix of the quantitative (scores on IRRBB ratios) and qualitative (compliance with Basel core principles) criteria. To further strengthen the supervisory toolkit for IRRBB, the NBB is developing a tool to monitor the IRRBB position of major banks on a quarterly basis.

The NBB has observed divergences in approaches used by banks to measure and calculate IRRBB, and take this into account in its supervisory appraisal of reported IRRBB indicators. Going forward, the NBB will further analyze both the qualitative and quantitative aspects of these divergences to ensure a full comprehension of interest rate risks. Concerning qualitative aspects, attention will be paid to factors such as i.e., combining views of ALM and treasury departments on IRRBB and ensuring the functional separation between Head of Treasury and Head of Markets at banks.

While the regulatory framework is clear and comprehensive regarding the Board's involvement, the supervisory framework is less clear to determine how well the Board is meeting its obligations set out in this criterion. The frequency of engagement with the board by the supervisor is not mandated by the supervisory framework. In practice, the supervisor will meet frequently with the larger systemic banks, which would typically include the CFO, CEO and CRO. The engagement does not, however, extend systematically 


\begin{tabular}{|c|c|}
\hline & $\begin{array}{l}\text { to the board of directors of all banks. } \\
\text { The supervisor does perform assessments of board reports carried out at least annually } \\
\text { when the scorecard is updated as part of the SREP. The board reporting and minutes cover } \\
\text { a number of risk areas. }\end{array}$ \\
\hline EC2 & $\begin{array}{l}\text { The supervisor determines that banks have in place comprehensive and appropriate } \\
\text { interest rate risk measurement systems and that any models and assumptions are validated } \\
\text { on a regular basis. It confirms that banks' limits reflect the risk strategy of the institution } \\
\text { and are understood by and regularly communicated to relevant staff. The supervisor also } \\
\text { confirms that exceptions to established policies, processes and limits should receive the } \\
\text { prompt attention of senior management, and the Board where necessary. }\end{array}$ \\
\hline $\begin{array}{l}\text { Description and } \\
\text { findings re } E C 2\end{array}$ & 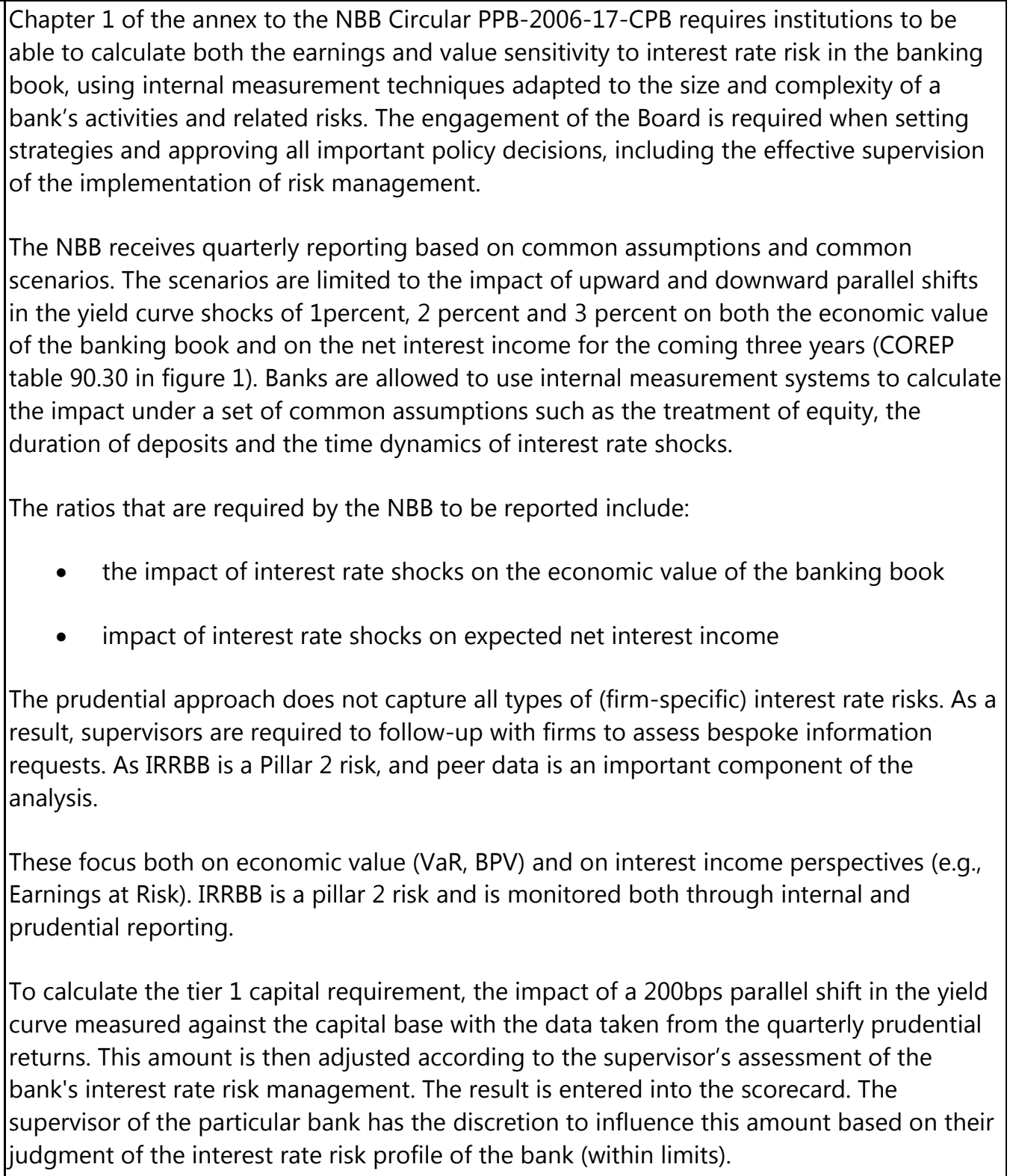 \\
\hline
\end{tabular}




\begin{tabular}{|c|c|}
\hline & $\begin{array}{l}\text { As IRRBB is a Pillar } 2 \text { risk, the internal models used to calculate this risk are not required to } \\
\text { be approved by the NBB. In this context, there might be a divergence in quality of } \\
\text { modeling, quality of data inputs into the models, differences in assumptions and modeling } \\
\text { approaches all leading to different model outputs. Without a detailed analysis of the } \\
\text { various factors, an appreciation of the inherent risk profile might be difficult to identify let } \\
\text { alone compare against a peer group. } \\
\text { The NBB recognizes that more attention should go to the follow-up of risk positions by } \\
\text { supervisors (i.e., inputs to the calculations), and to the profitability component in measuring } \\
\text { the risk. Enhancements of reporting does not always include all material exposures and } \\
\text { risks. }\end{array}$ \\
\hline EC3 & $\begin{array}{l}\text { The supervisor requires that banks periodically perform appropriate stress tests to measure } \\
\text { their vulnerability to loss under adverse interest rate movements. }\end{array}$ \\
\hline $\begin{array}{l}\text { Description and } \\
\text { findings re EC3 }\end{array}$ & $\begin{array}{l}\text { The requirement for banks to perform period stress tests is clearly set out in the } \\
\text { regulations. } \$ 2.2 \text { of chapter } 1 \text { of the annex to the NBB Circular PPB-2006-17-CPB states that } \\
\text { in accordance with international guidelines on IRRBB, the interest rate risk management } \\
\text { function of banks should include the incorporation of possible stress scenarios such as } \\
\text { considerable shocks, changes in correlations and changes in behavioral assumptions. } \\
\text { In practice, the NBB has observed through inspections that many banks do perform interest } \\
\text { rate risk stress tests, largely focused on the impact of a set of different interest rate } \\
\text { scenarios, both general and specific to the institutions (e.g., basis risk). More attention } \\
\text { seems needed in stress testing changes in behavioral assumption (e.g., duration of } \\
\text { deposits, convexity in prepayments). It is also unclear to what extent top management is } \\
\text { exposed to the results. The sophistication of stress testing practices at the non-systemic } \\
\text { banks is an area for improvement. }\end{array}$ \\
\hline \multicolumn{2}{|l|}{$\begin{array}{l}\text { Additional } \\
\text { criteria }\end{array}$} \\
\hline AC1 & $\begin{array}{l}\text { The supervisor has the power to obtain from banks the results of their internal interest rate } \\
\text { risk measurement systems, expressed in terms of the threat to economic value, including } \\
\text { using a standardized interest rate shock on the banking book. }\end{array}$ \\
\hline $\begin{array}{l}\text { Description and } \\
\text { findings re } A C 1\end{array}$ & $\begin{array}{l}\text { Banks report the results of their internal interest rate risk measurement systems quarterly, } \\
\text { expressed in terms of the threat to economic value and net interest income. For the larger } \\
\text { systemic banks, the analysis of this data is relatively well developed and comprehensive. } \\
\text { Requirements under chapter } 1 \text { of the annex to the NBB Circular PPB-2006-17-CPB require } \\
\text { banks report quarterly the outcome of a standardized interest rate shock on the banking } \\
\text { book (COREP table 90.30). The Banking Law sets out powers for the NBB to obtain any } \\
\text { reporting it considers relevant to the supervision of a credit institution. }\end{array}$ \\
\hline AC2 & $\begin{array}{l}\text { The supervisor assesses whether the internal capital measurement systems of banks } \\
\text { adequately capture the interest rate risk in the banking book. }\end{array}$ \\
\hline $\begin{array}{l}\text { Description and } \\
\text { findings re AC2 }\end{array}$ & $\begin{array}{l}\text { The annual analysis of the ICAAP is the main exercise that considers the internal capital } \\
\text { measurement system. The ICAAP review includes IRRBB as a Pillar } 2 \text { risk. For certain large } \\
\text { complex banks, the NBB base prudential capital requirements on the internal analysis, for }\end{array}$ \\
\hline
\end{tabular}




\begin{tabular}{|c|c|}
\hline & $\begin{array}{l}\text { other banks the NBB has opted to use the SREP analysis as these better capture the interest } \\
\text { rate risk in the banking book. }\end{array}$ \\
\hline$A C 3$ & $\begin{array}{l}\text { The supervisor requires stress tests to be based on reasonable worst case scenarios and to } \\
\text { capture all material sources of risk, including a breakdown of critical assumptions. Senior } \\
\text { management is required to consider these results when establishing and reviewing a bank's } \\
\text { policies, processes and limits for interest rate risk }\end{array}$ \\
\hline $\begin{array}{l}\text { Description and } \\
\text { findings re AC3 }\end{array}$ & $\begin{array}{l}\text { The requirement for the stress tests to consider a worst case scenario is not explicitly } \\
\text { mentioned. }\end{array}$ \\
\hline AC4 & $\begin{array}{l}\text { Interest rate risk management at large institutions is assigned to ALM departments, which } \\
\text { report separately from risk-taking departments. From a functional perspective, the NBB } \\
\text { regulations and guidance do not formally require a separation of staff responsible for } \\
\text { Treasury and markets activity and this has been a prudential issue for the NBB. However, } \\
\text { recent on-site examinations of liquidity risk management and of dealing room activities of } \\
\text { large banks have resulted in specific NBB recommendations to separate the treasury } \\
\text { function and such risk-taking activities. } \\
\text { Even though such supervisory actions and the growing awareness of the large banks result } \\
\text { in increasing adherence to this best practices, this matter remains a specific area for } \\
\text { attention by the NBB. }\end{array}$ \\
\hline $\begin{array}{l}\text { Description and } \\
\text { findings re AC4 }\end{array}$ & $\begin{array}{l}\text { Interest rate risk management at large institutions is assigned to ALM departments, which } \\
\text { report separately from risk-taking departments. From a functional perspective, the NBB } \\
\text { does not require separation of staff responsible for Treasury and markets activity and this } \\
\text { has been a prudential issue for the NBB. } \\
\text { This is a specific area for attention by the NBB to require function separation of treasury } \\
\text { staff and markets staff. }\end{array}$ \\
\hline $\begin{array}{l}\text { Assessment of } \\
\text { Principle } 16\end{array}$ & Compliant \\
\hline Comments & $\begin{array}{l}\text { The regulatory and supervisory framework for managing interest rate risk is well } \\
\text { established and executed. The NBB has made strong efforts to implement new standards } \\
\text { and has embedded interest rate risk in its core work. The program could be further } \\
\text { enhanced as follows: } \\
\text { - Write a single regulation to replace multiple rules texts. Include requirements for } \\
\text { stress testing, limit that NBB reflects their risk appetite. } \\
\text { Strengthen the regulatory framework with a requirement for a functional and } \\
\text { operational separation of markets and treasury function. } \\
\text { Requirement of an ALCO for all credit institutions, which will enhance the quality, } \\
\text { timeliness and management of this risk. } \\
\text { Extend cross-sectoral analysis to a greater number of banks. Improve the } \\
\text { identification of outliers and strengthen the transfer of skills to supervisor. }\end{array}$ \\
\hline
\end{tabular}




\begin{tabular}{|c|c|}
\hline Principle 17 & $\begin{array}{l}\text { Internal control and audit. Supervisors must be satisfied that banks have in place internal } \\
\text { controls that are adequate for the size and complexity of their business. These should } \\
\text { include clear arrangements for delegating authority and responsibility; separation of the } \\
\text { functions that involve committing the bank, paying away its funds, and accounting for its } \\
\text { assets and liabilities; reconciliation of these processes; safeguarding the bank's assets; and } \\
\text { appropriate independent internal audit and compliance functions to test adherence to } \\
\text { these controls as well as applicable laws and regulations. }\end{array}$ \\
\hline Essential criteria & \\
\hline EC1 & $\begin{array}{l}\text { Laws, regulations or the supervisor establish the responsibilities of the Board and senior } \\
\text { management with respect to corporate governance to ensure that there is effective control } \\
\text { over a bank's entire business. }\end{array}$ \\
\hline $\begin{array}{l}\text { Description and } \\
\text { findings re EC1 }\end{array}$ & 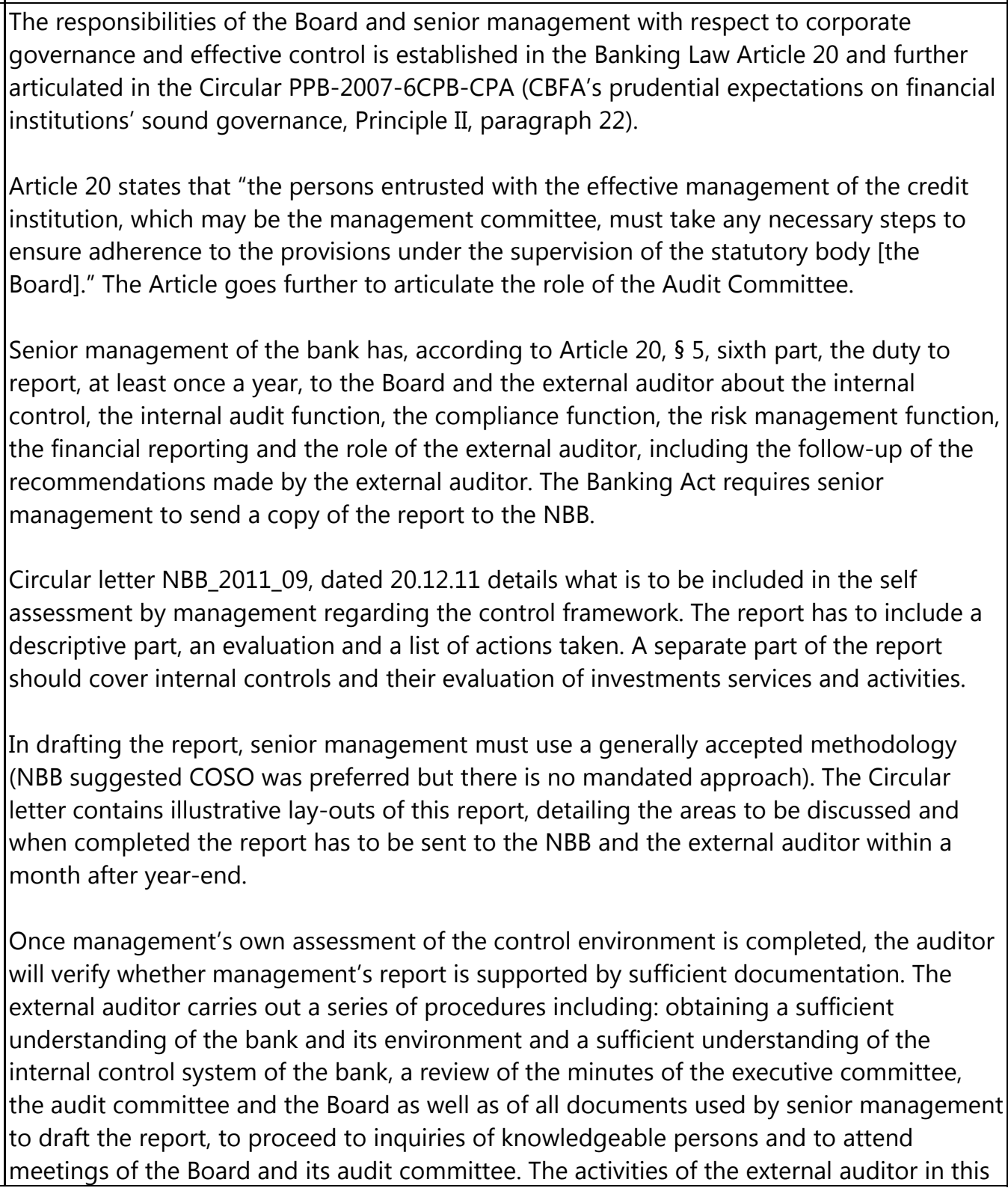 \\
\hline
\end{tabular}




\begin{tabular}{|c|c|}
\hline & regard are set out in Circular letter CBFA_2009_19 dated 20.12.2011. \\
\hline EC2 & $\begin{array}{l}\text { The supervisor determines that banks have in place internal controls that are adequate for } \\
\text { the nature and scale of their business. These controls are the responsibility of the Board } \\
\text { and/or senior management and deal with organizational structure, accounting policies and } \\
\text { processes, checks and balances, and the safeguarding of assets and investments. More } \\
\text { specifically, these controls address: } \\
\text { - Organizational structure: definitions of duties and responsibilities, including clear } \\
\text { delegation of authority (for example, clear loan approval limits), decision-making } \\
\text { policies and processes, separation of critical functions (for example, business } \\
\text { origination, payments, reconciliation, risk management, accounting, audit and } \\
\text { compliance). } \\
\text { Accounting policies and processes: reconciliation of accounts, control lists, } \\
\text { information for management. } \\
\text { Checks and balances (or "four eyes principle"): segregation of duties, cross- } \\
\text { checking, dual control of assets, double signatures. } \\
\text { Safeguarding assets and investments: including physical control. }\end{array}$ \\
\hline $\begin{array}{l}\text { Description and } \\
\text { findings re EC2 }\end{array}$ & $\begin{array}{l}\text { Article } 20, \S 1 \text { of the Banking Law sets out the requirements for internal controls such as: } \\
\text { organizational structure; administrative and accounting organization; control and security } \\
\text { measures relating to electronic data processing; and an appropriate internal control. The } \\
\text { requirements are further set out in the Circular letter D1 } 97 / 4 \text { dated } 30.06 .97 \text { about internal } \\
\text { controls and internal audit (currently under revision to be updated) in line with the BCBS } \\
\text { document about The internal audit function in banks)... } \\
\text { The auditor's report is received and reviewed by the NBB. It is used in the overall } \\
\text { scorecarding approach to help make an assessment of risk management and audit } \\
\text { functions. Supervisors will also take account of the remedial actions undertaken by } \\
\text { management. If there is no adverse information, the external audit report will not trigger } \\
\text { any action by the NBB. Importantly, there is no systematic verification by the NBB of the } \\
\text { completeness or comprehensiveness of management's self assessment or the work of the } \\
\text { external auditor Verification is done in the context of the off-site examinations, the on-site } \\
\text { inspections or when periodically meeting with the external auditor and the head of the } \\
\text { internal audit function (according to Circular letter D1 } 97 / 4 \text { dated } 30.06 .97 \text { ). } \\
\text { While the regulations appear to be satisfactory, the process entails a self assessment } \\
\text { process by management and certification by the auditor regarding the process. There is no } \\
\text { positive assurance as to the design of controls or to the effectiveness of controls. It would } \\
\text { also appear that the NBB does not conduct its own testing of the control environment. } \\
\text { The external auditor, based on the report of senior management, examines the internal } \\
\text { control measures taken by the bank and sends his/her observations to the NBB with a copy } \\
\text { to the bank. These legal obligations are complemented by two Circular letters. In providing } \\
\text { the report, the auditor is not required to give a positive assurance of the control } \\
\text { environment. The Circular does not provide guidance regarding the extent of testing } \\
\text { required to arrive at the audit opinion. Moreover, there was no automatic supervisory } \\
\text { activity for the NBB to examine the control testing of the auditor. }\end{array}$ \\
\hline
\end{tabular}




\begin{tabular}{|c|c|}
\hline EC3 & $\begin{array}{l}\text { Laws, regulations or the supervisor place the responsibility for the control environment on } \\
\text { the Board and senior management of the bank. The supervisor requires that the Board and } \\
\text { senior management understand the underlying risks in their business and are committed to } \\
\text { a strong control environment. }\end{array}$ \\
\hline $\begin{array}{l}\text { Description and } \\
\text { findings re EC3 }\end{array}$ & $\begin{array}{l}\text { When certain quantitative thresholds have been passed (balance sheet total, turn-over, } \\
\text { number of employees), a credit institution is indeed required to set up an Audit Committee } \\
\text { (see art. } 20 \text { \$2bis, third paragraph of the Banking Law ). At subsidiary level, it may be } \\
\text { possible, under certain conditions, to obtain a waiver of this requirement in case there is an } \\
\text { Audit committee at group level (art. } 20 \text { §2bis, fourth paragraph). } \\
\text { The minimum tasks of the Audit Committee are described in art. } 20 \S 5 \text {, second paragraph. } \\
\text { The audit committee does not itself make decisions and must report to the Board, which } \\
\text { thenmakes necessary decisions upon the recommendations of the committee. } \\
\text { In the case where the credit institution must set up a Board Audit Committee or a } \\
\text { Remuneration Committee, at least one member of these committees must be a non- } \\
\text { executive director that meets the independence criteria as set out in art. } 526 \text { ter of the } \\
\text { Company Law Code (art. } 20 \S 2 \text { bis, first paragraph and } \$ 2 \text { ter, first paragraph Banking Law). } \\
\text { While the NBB requires at least one independent director at the subsidiary level, as a } \\
\text { counterweight for the group influence, it is questionable whether a single independent } \\
\text { director is satisfactory. The requirement is in accordance with article } 41 \text { of the European } \\
\text { Directive } 2006 / 43 / E C \text { of } 17.05 .2006 \text {. } \\
\text { According to the law and the related Circular letter, senior management should set up an } \\
\text { adequate internal control system and ensure that it is assessed at least once a year. At least } \\
\text { once a year, the senior management reports to the Board on the state of the internal } \\
\text { control system, through the audit committee if one exists. The NBB supervises the correct } \\
\text { implementation of these requirements via its on-site and off-site examinations. }\end{array}$ \\
\hline EC4 & $\begin{array}{l}\text { The supervisor has the power to require changes in the composition of the Board and } \\
\text { senior management to address any prudential concerns related to the satisfaction of these } \\
\text { criteria. }\end{array}$ \\
\hline $\begin{array}{l}\text { Description and } \\
\text { findings re EC4 }\end{array}$ & $\begin{array}{l}\text { Fit and proper powers allow for the NBB to change the composition of the Board as it has a } \\
\text { collective element and has been expanded to extend to executive and non-executive } \\
\text { directors. The Communication includes the Fit \& Proper forms as per the CBFA } 200920 \text { of } 8 \\
\text { May } 2009 \text { permits the NBB to issue an opinion regarding the reappointment of a non } \\
\text { executive director. However, the Circular does not extend to persons who perform control } \\
\text { functions at the highest level (compliance officer, auditor general, risk manager, appointed } \\
\text { actuary) or senior managers and are these are therefore beyond the scope of the NBB's } \\
\text { powers. } \\
\text { Even though (see EC } 8 \text { of Principle 3), it is part of a credit institution's overall governance } \\
\text { obligations that persons appointed to prudentially significant executive services or key } \\
\text { functions (internal audit officer, compliance officer, risk management officer, appointed } \\
\text { actuary, etc.) are fit and proper and have the necessary knowledge and experience. The } \\
\text { NBB can evaluate this as well as part of overall governance supervision. The fit and proper } \\
\text { requirements are not explicitly extended to persons outside of the directors of board, but } \\
\text { this will be covered in the upcoming new fit and proper regulation. }\end{array}$ \\
\hline
\end{tabular}




\begin{tabular}{|c|c|}
\hline EC5 & $\begin{array}{l}\text { The supervisor determines that there is an appropriate balance in the skills and resources } \\
\text { of the back office and control functions relative to the front office/business origination. }\end{array}$ \\
\hline $\begin{array}{l}\text { Description and } \\
\text { findings re EC5 }\end{array}$ & $\begin{array}{l}\text { Circular letter B90/1 dated } 17.04 .90 \text { specifically describes how market activities should be } \\
\text { organized, managed and followed-up. It describes the various risks including exchange } \\
\text { risks, interest rate risk, liquidity risk, counterparty risk and country risk. The Circular } \\
\text { emphasizes the importance of an appropriate organizational structure. Supervisory testing } \\
\text { of implementation would come from a number of inputs: annual internal controls, external } \\
\text { auditor report confirming management's self assessment, contact with the credit institution } \\
\text { and onsite inspections. } \\
\text { Onsite inspection would be the most effective supervisory activity in arriving at this } \\
\text { determination but would not necessarily be performed annually for all credit institutions. } \\
\text { Risk scorecarding will determine the onsite review cycle. }\end{array}$ \\
\hline EC6 & $\begin{array}{l}\text { The supervisor determines that banks have a permanent compliance function that assists } \\
\text { senior management in managing effectively the compliance risks faced by the bank. The } \\
\text { compliance function must be independent of the business activities of the bank. The } \\
\text { supervisor determines that the Board exercises oversight of the management of the } \\
\text { compliance function. }\end{array}$ \\
\hline $\begin{array}{l}\text { Description and } \\
\text { findings re EC6 }\end{array}$ & $\begin{array}{l}\text { Article 20, § 3, third part of the Banking Act complemented by Circular letter D1 2001/13 } \\
\text { dated 18.12.01 on the compliance function (under revision) require all banks to have an } \\
\text { independent and effective compliance function. The same article requires banks to } \\
\text { elaborate an integrity policy, which is regularly updated based on a risk assessment. } \\
\text { The integrity policy covers at least all relevant laws, including money laundering, financing } \\
\text { of terrorism, fraud, discrimination, and internal codes. The compliance function ensures the } \\
\text { effective implementation of the integrity policy of the bank. } \\
\text { Banks have one compliance function under the responsibility of a member of senior } \\
\text { management. The compliance function is responsible for compliance with all laws and } \\
\text { regulations. The new draft Circular letter is a joint document of the NBB and the FSMA and } \\
\text { lists the various legislation, each regulator is responsible for (e.g., money laundering is a } \\
\text { responsibility of the NBB and rules of conduct a responsibility of the FSMA). Nevertheless, } \\
\text { article 20, § } 4 \text { of the banking act states that there is one compliance function under the } \\
\text { responsibility of the NBB. } \\
\text { The new draft Circular letter has been published for consultation. }\end{array}$ \\
\hline EC7 & $\begin{array}{l}\text { The supervisor determines that banks have an independent, permanent and effective } \\
\text { internal audit function charged with (i) ensuring that policies and processes are complied } \\
\text { with and (ii) reviewing whether the existing policies, processes and controls remain } \\
\text { sufficient and appropriate for the bank's business. }\end{array}$ \\
\hline $\begin{array}{l}\text { Description and } \\
\text { findings re EC7 }\end{array}$ & $\begin{array}{l}\text { Article 20, } \S 3 n \text { second part of the banking act complemented by circular letter D1 } 97 / 4 \\
\text { dated } 30.06 .97 \text { on internal control system and internal audit function require banks to have } \\
\text { an independent and effective internal audit function. } \\
\text { The internal audit function } \\
\text { - provides the bank's senior management with an independent assurance about the } \\
\text { adequacy and effectiveness of the internal control system; }\end{array}$ \\
\hline
\end{tabular}




\begin{tabular}{|c|c|}
\hline & 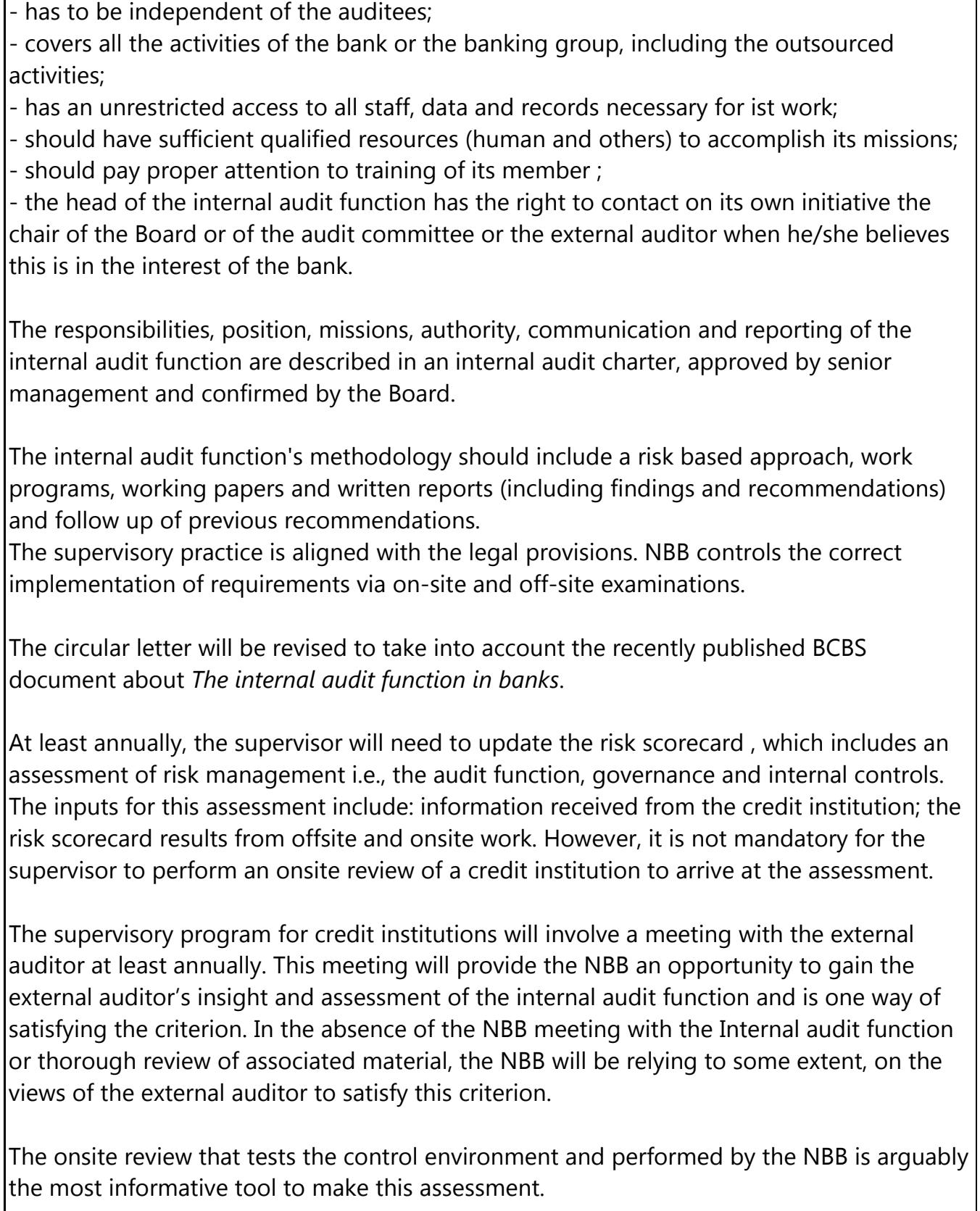 \\
\hline EC8 & $\begin{array}{l}\text { The supervisor determines that the internal audit function: } \\
\text { has sufficient resources, and staff that are suitably trained and have relevant } \\
\text { experience to understand and evaluate the business they are auditing; } \\
\text { has appropriate independence, including reporting lines to the Board and status } \\
\text { within the bank to ensure that senior management reacts to and acts upon its } \\
\text { recommendations; } \\
\text { has full access to and communication with any member of staff as well as full } \\
\text { access to records, files or data of the bank and its affiliates, whenever relevant to } \\
\text { the performance of its duties; } \\
\text { employs a methodology that identifies the material risks run by the bank; } \\
\text { - prepares an audit plan based on its own risk assessment and allocates its }\end{array}$ \\
\hline
\end{tabular}




\begin{tabular}{|c|c|}
\hline & $\begin{array}{l}\text { resources accordingly; and } \\
\text { has the authority to assess any outsourced functions. }\end{array}$ \\
\hline $\begin{array}{l}\text { Description and } \\
\text { findings re EC8 }\end{array}$ & $\begin{array}{l}\text { There is no systematic process for the supervisor to make an assessment of the internal } \\
\text { audit function across all banks on at least an annual cycle. The NBB may obtain the internal } \\
\text { audit plan and will be informed of major adverse audit findings. Whilst these inputs might } \\
\text { come to the attention of the NBB, there was no systematic supervisory process to ensure } \\
\text { this is so for smaller banks. For the larger systemic banks, the frequency of engagement } \\
\text { with the internal audit function was clearly apparent. }\end{array}$ \\
\hline \multicolumn{2}{|l|}{$\begin{array}{l}\text { Additional } \\
\text { criteria }\end{array}$} \\
\hline AC1 & $\begin{array}{l}\text { In those countries with a unicameral Board structure (as opposed to a bicameral structure } \\
\text { with a Supervisory Board and a Management Board), the supervisor requires the Board to } \\
\text { include a number of experienced non-executive directors. }\end{array}$ \\
\hline $\begin{array}{l}\text { Description and } \\
\text { findings re } A C 1\end{array}$ & $\begin{array}{l}\text { The NBB strongly recommends that the Board is made of a majority of non-executive } \\
\text { directors but this is not mandated. } \\
\text { Where the financial institution has instituted a management committee, it should allocate } \\
\text { the functions of e.g., chairman of the board of directors and chairman of the management } \\
\text { committee to different persons, namely a non-executive and an executive director } \\
\text { respectively. }\end{array}$ \\
\hline AC2 & $\begin{array}{l}\text { The supervisor requires the internal audit function to report to an audit committee, or an } \\
\text { equivalent structure. }\end{array}$ \\
\hline $\begin{array}{l}\text { Description and } \\
\text { findings re AC2 }\end{array}$ & $\begin{array}{l}\text { The primary reporting line of the internal audit function is to senior management. Senior } \\
\text { management has to inform the Board at least once a year about the state of the internal } \\
\text { control system through the audit committee. This existing practice will be revised to take } \\
\text { into account the recently published BCBS document about The internal audit function in } \\
\text { banks: awaiting the formal transposition of this BCBS document, the NBB has taken a } \\
\text { proactive approach towards principle } 12 \text { of this document. }\end{array}$ \\
\hline AC3 & $\begin{array}{l}\text { In those countries with a unicameral Board structure, the supervisor requires the audit } \\
\text { committee to include experienced non-executive directors. }\end{array}$ \\
\hline $\begin{array}{l}\text { Description and } \\
\text { findings re AC3 }\end{array}$ & $\begin{array}{l}\text { Article } 20, \S 2 \text { bis of the banking act requires states that only non-executive directors may be } \\
\text { member of the audit committee. }\end{array}$ \\
\hline AC4 & $\begin{array}{l}\text { Laws or regulations provide, or the supervisor ensures, that banks must notify the } \\
\text { supervisor as soon as they become aware of any material information, which may } \\
\text { negatively affect the fitness and propriety of a Board member or a member of the senior } \\
\text { management. }\end{array}$ \\
\hline $\begin{array}{l}\text { Description and } \\
\text { findings re AC4 }\end{array}$ & $\begin{array}{l}\text { This is not explicitly provided for in laws or regulations, but as part of a general } \\
\text { transparency obligation towards the supervisor, there is an expectation that banks would } \\
\text { do so. } \\
\text { Also, the current NBB's fit and proper test is repeated every time a director must be re- } \\
\text { appointed (which is in Belgian corporate practice usually every three to six years), so }\end{array}$ \\
\hline
\end{tabular}




\begin{tabular}{|c|c|}
\hline & $\begin{array}{l}\text { regular re-assessment is done in practice. } \\
\text { As mentioned under EC } 8 \text { of principle 3, the NBB's fit \& proper policy is under review and } \\
\text { an ongoing reporting obligation around the fit \& proper character is envisaged. }\end{array}$ \\
\hline $\begin{array}{l}\text { Assessment of } \\
\text { Principle } 17\end{array}$ & Largely Compliant \\
\hline Comments & $\begin{array}{l}\text { The NBB will perform a variety of supervisory activities on a risk-based protocol (e.g., off- } \\
\text { site examinations, the on-site inspections or meeting with the external auditor and the } \\
\text { head of the internal audit function). However, there is no fixed or mandated frequency of } \\
\text { onsite examinations by the NBB to test the effectiveness of the control environment for all } \\
\text { banks. These issues are however recurring themes of the NBB's supervision. Indeed, it is } \\
\text { apparent that for the larger systemic banks assessment of controls and internal audit is } \\
\text { performed regularly. For the smaller banks, the frequency is not mandated at a minimum. } \\
\text { In the absence of an onsite review performed by the NBB, considerable reliance is placed } \\
\text { on the external auditor to verify the effectiveness of the control environment. The } \\
\text { frequency, depth and comprehensiveness of the testing of the control environment by the } \\
\text { NBB should be mandated at a minimum frequency of annually. }\end{array}$ \\
\hline Principle 18 & $\begin{array}{l}\text { Abuse of financial services. Supervisors must be satisfied that banks have adequate } \\
\text { policies and processes in place, including strict "know-your-customer" rules, that promote } \\
\text { high ethical and professional standards in the financial sector and prevent the bank from } \\
\text { being used, intentionally or unintentionally, for criminal activities. }\end{array}$ \\
\hline Essential criteria & \\
\hline EC1 & $\begin{array}{l}\text { Laws or regulations clarify the duties, responsibilities and powers of the banking supervisor } \\
\text { and other competent authorities, if any, related to the supervision of banks' internal } \\
\text { controls and enforcement of the relevant laws and regulations regarding criminal activities. }\end{array}$ \\
\hline $\begin{array}{l}\text { Description and } \\
\text { findings re EC1 }\end{array}$ & $\begin{array}{l}\text { AML/CFT obligations of financial institutions are defined by the Law of } 11 \text { January } 1993 \text { on } \\
\text { the prevention of the use of the financial system for money laundering and terrorism } \\
\text { financing and modified by the Laws of } 18 \text { January } 2010 \text { and } 26 \text { November 2011, the } \\
\text { Programme Law (I) of } 29 \text { March } 2012 \text { and the Royal Decrees of } 6 \text { May 2010, } 3 \text { March } 2011 \\
\text { and } 2 \text { June } 2012 \text {. } \\
\text { The rules on practical enforcement of that Law were defined, for the financial sector, by the } \\
\text { Regulation of } 23 \text { February } 2010 \text { of the Banking, Finance and Insurance Commission on the } \\
\text { prevention of money laundering and terrorism financing approved by the Royal Decree of } \\
16 \text { March } 2010 \text {. } \\
\text { As regards coercive measures and sanctions in the field of AML/CFT, the provisions were } \\
\text { described in } \S 512 \text { of Belgium's REM of June } 2005 \text {. }\end{array}$ \\
\hline EC2 & $\begin{array}{l}\text { The supervisor must be satisfied that banks have in place adequate policies and processes } \\
\text { that promote high ethical and professional standards and prevent the bank from being } \\
\text { used, intentionally or unintentionally, for criminal activities. This includes the prevention } \\
\text { and detection of criminal activity, and reporting of such suspected activities to the } \\
\text { appropriate authorities. }\end{array}$ \\
\hline
\end{tabular}




\begin{tabular}{|c|c|}
\hline & $\begin{array}{l}\text { Since } 1 \text { April } 2011 \text { the NBB is charged with the regulation, monitoring and sanctioning as } \\
\text { regards AML/CFT for credit institutions as well as stockbroking firms, insurance } \\
\text { undertakings, settlement institutions and institutions equivalent to settlement institutions, } \\
\text { payment institutions and electronic money institutions. } \\
\text { The NBB has a range of processes at its disposal to become satisfied with banks risk } \\
\text { management for this Principle: offsite analysis; onsite reviews; meetings with internal and } \\
\text { external auditors; meetings with compliance officers/MROs etc. A systematic supervision } \\
\text { plan for all credit institutions was not evidenced, which would help determine how the } \\
\text { supervisory tools are deployed in a risk-based approach. In a situation where an onsite } \\
\text { review or meeting with auditors is not performed, the NBB will rely on information such the } \\
\text { annual activity reports submitted by the senior management of the financial institution (per } \\
\text { Article } 35 \S 4 \text {, of the CBFA regulation of } 23 \text { February 2010). } \\
\text { Where the NBB deems necessary, credit institutions are required to submit off-site } \\
\text { reporting on particular occasions. When the } 2010 \text { rules were put in place all banks were } \\
\text { required to report on the transition to new rules with escalation of process where answers } \\
\text { were unsatisfactory. A further review of compliance is planned for December } 2012 \text {. The } \\
\text { NBB has also undertaken special reviews acting on information received from the financial } \\
\text { intelligence unit. } \\
\text { It was not evidenced from the review that the NBB had performed an assessment of } \\
\text { transition plans for compliance with the new rules systematically across the population of } \\
\text { banks to become satisfied with the adequacy of policies and processes to satisfy Principle } \\
18 \text {. }\end{array}$ \\
\hline EC3 & $\begin{array}{l}\text { In addition to reporting to the financial intelligence unit or other designated authorities, } \\
\text { banks report to the banking supervisor suspicious activities and incidents of fraud when } \\
\text { they are material to the safety, soundness or reputation of the bank. }\end{array}$ \\
\hline & $\begin{array}{l}\text { Financial institutions are not required to transmit a copy of all suspicious transactions that } \\
\text { are sent to the CTIF/CFI in accordance with the Law of } 11 \text { January } 1993 \text { on AML/CFT to the } \\
\text { NBB. The minimum reporting requirements for reporting is the annual activity report of the } \\
\text { AML officer. } \\
\text { However, under Article 39, § 2, of that Law, the competent supervisory authorities "may } \\
\text { require from the organizations and individuals subject to their supervision (...) all the } \\
\text { information they deem appropriate as regards the manner in which these organizations and } \\
\text { individuals implement Articles } 7 \text { to } 20,23 \text { to } 30 \text { and 33." Similarly, Article } 46 \text {, paragraph } 4 \text {, of } \\
\text { the Banking Law of } 22 \text { March } 1993 \text { states that "the Bank may ask for information about the } \\
\text { financial positions and transactions of credit institutions, and also about the way in which } \\
\text { they are organized and operate." These provisions also apply to suspicious transaction } \\
\text { reports submitted to the CTIF/CFI. } \\
\text { In the absence of immediate reporting requirements to the NBB of suspicious transactions, } \\
\text { the NBB must rely on other sources of information to become aware of situations where a } \\
\text { particular financial institution fails to correctly comply with its reporting obligations, which } \\
\text { may inhibit the NBB's ability to react quickly and enforce prompt corrective action. } \\
\text { The CTIF is obliged to inform the NBB in all cases where a bank has failed to comply with } \\
\text { reporting obligations. The NBB is obliged to inform the CTIF when it imposes a sanction } \\
\text { related to a failure to report. }\end{array}$ \\
\hline
\end{tabular}




\begin{tabular}{|c|c|}
\hline EC4 & $\begin{array}{l}\text { The supervisor is satisfied that banks establish "know-your-customer" }(\mathrm{KYC}) \text { policies and } \\
\text { processes, which are well documented and communicated to all relevant staff. Such policies } \\
\text { and processes must also be integrated into the bank's overall risk management. The KYC } \\
\text { management program, on a group-wide basis, has as its essential elements: } \\
\text { a customer acceptance policy that identifies business relationships that the bank } \\
\text { will not accept; } \\
\text { a customer identification, verification and due diligence program; this } \\
\text { encompasses verification of beneficial ownership and includes risk-based reviews } \\
\text { to ensure that records are updated and relevant; } \\
\text { policies and processes to monitor and recognize unusual or potentially suspicious } \\
\text { transactions, particularly of high-risk accounts; } \\
\text { escalation to the senior management level of decisions on entering into business } \\
\text { relationships with high-risk accounts, such as those for politically exposed persons, } \\
\text { or maintaining such relationships when an existing relationship becomes high-risk; } \\
\text { and } \\
\text { clear rules on what records must be kept on consumer identification and individual } \\
\text { transactions and their retention period. Such records should have at least a five year } \\
\text { retention period. }\end{array}$ \\
\hline & $\begin{array}{l}\text { In the } 2005 \text { mutual assessment of Belgium, the FATF deemed the procedures in place in the } \\
\text { Belgian financial sector to be largely compliant with Recommendation } 5 \text { (know-your- } \\
\text { customer), including measures for identification and verification of identity of customers } \\
\text { and beneficial owners and the exercise of due diligence in respect of business relationships } \\
\text { and occasional transactions. The existing provisions were also deemed to be largely } \\
\text { compliant with Recommendation } 6 \text { (PEPs). } \\
\text { The requirement of written reports relating to unusual transactions and the obligation to } \\
\text { submit these reports to the AML/CFT officer in the financial institution were described in } \\
\text { Belgium's } 2005 \text { REM (see in particular } \S 335,338,341 \text { and section } 3.6 .1 \text { ). The FATF deemed } \\
\text { the mechanisms for monitoring the operations and business relationships to be fully } \\
\text { compliant with Recommendation } 11 \text { (unusual transactions). } \\
\text { As regards the group approach, the FATF deemed the system in place in the financial } \\
\text { sector to be largely compliant with Recommendation } 22 . \\
\text { Article } 16, \S 2, \text { of the Law of } 11 \text { January } 1993 \text { on preventing use of the financial system for } \\
\text { purposes of money laundering and terrorist financing requires that; "... credit institutions ... } \\
\text { set up a coordinated program and introduce a coordinated structure and coordinated } \\
\text { procedures for the entity they form with their subsidiaries and branches regarding their } \\
\text { obligations with respect to the prevention of money laundering and terrorist financing." } \\
\text { The } 2010 \text { regulation, incorporates by reference the BCBS "Consolidated Know Your } \\
\text { Customer Risk Management" paper dated of October } 2004 \text { (introduction to section 10.3.2). } \\
\text { The Circular requires each financial group with a Belgian parent to develop a global } \\
\text { AML/CFT risk management program that must be effectively implemented by each entity } \\
\text { of the group; to include, inter alia the client identification process and the customers } \\
\text { acceptance policy; }\end{array}$ \\
\hline
\end{tabular}




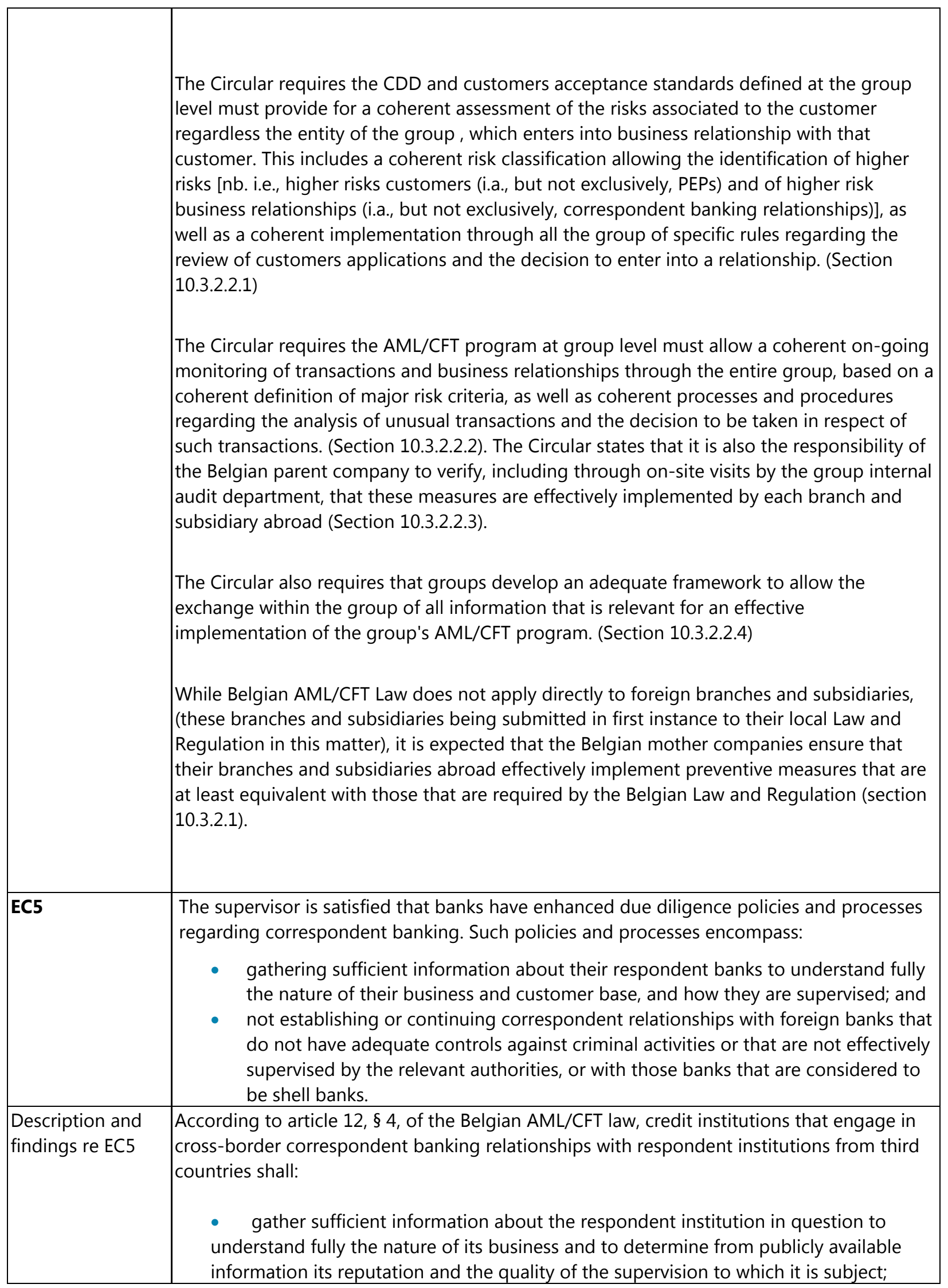




\begin{tabular}{|c|c|}
\hline & $\begin{array}{l}\text { assess the respondent institution's anti-money laundering and anti-terrorist } \\
\text { financing controls; } \\
\text { obtain approval from a sufficiently senior management level before establishing } \\
\text { new relationships; } \\
\text { - document in writing the respective responsibilities of each institution; } \\
\text { institution has verified the identity of and performed ongoing due diligence on the } \\
\text { customers having direct access to accounts of the correspondent and that it is able to } \\
\text { provide relevant customer due diligence data to the correspondent institution, upon } \\
\text { request. } \\
\text { They shall not enter into or continue a correspondent banking relationship with a } \\
\text { shell bank and shall take appropriate measures to ensure that they do not engage in or } \\
\text { continue correspondent banking relationships with a bank that is known to permit its } \\
\text { accounts to be used by a shell bank. } \\
\text { The regulations satisfy the criterion for enhanced due diligence policies and processes } \\
\text { regarding correspondent banking. The supervisory activities perform a comprehensive } \\
\text { assessment of the due diligence policies and processes was not evidenced during the } \\
\text { review. }\end{array}$ \\
\hline EC6 & $\begin{array}{l}\text { The supervisor periodically confirms that banks have sufficient controls and systems in } \\
\text { place for preventing, identifying and reporting potential abuses of financial services, } \\
\text { including money laundering. }\end{array}$ \\
\hline $\begin{array}{l}\text { Description and } \\
\text { findings re EC6 }\end{array}$ & $\begin{array}{l}\text { Compliance with requirements to have such controls in place forms part of the off-site } \\
\text { monitoring and of the on -site inspection program. The NBB has demonstrated that it } \\
\text { undertakes detailed examinations of this are of concern while on-site. As described above, } \\
\text { periodic off-site reporting has also been undertaken. } \\
\text { It is unclear how monitoring of compliance is done for those small banks that are subject } \\
\text { only infrequently to on-site inspections. }\end{array}$ \\
\hline EC7 & $\begin{array}{l}\text { The supervisor has adequate enforcement powers (regulatory and/or criminal prosecution) } \\
\text { to take action against a bank that does not comply with its obligations related to criminal } \\
\text { activities. }\end{array}$ \\
\hline $\begin{array}{l}\text { Description and } \\
\text { findings re EC7 }\end{array}$ & $\begin{array}{l}\text { According to Article } 40 \text { of the Belgian AML/CFT Law, the NBB may, in case of non- } \\
\text { compliance by financial institutions with Articles } 7 \text { to } 20,23 \text { to } 30 \text { and } 33 \text { of this Law, with } \\
\text { Regulation (EC) No } 1781 / 2006 \text { of the European Parliament and of the Council of } 15 \\
\text { November } 2006 \text { on information on the payer accompanying transfers of funds or with their } \\
\text { implementing decrees: } \\
\text { - publish, in accordance with terms it determines, the decisions and measures it shall } \\
\text { adopt; and } \\
\quad \text { impose an administrative fine of not less than EUR } 250 \text { and not more than EUR } 1 \\
250 \text { 000. } \\
\text { The AML/CFT Law explicitly states that this specific sanction power is additional to the } \\
\text { measures laid down by other laws or regulations. The NBB can thus use all its enforcement } \\
\text { powers as laid down by the Law of } 22 \text { March } 1993 \text { in case a credit institution fails to comply } \\
\text { with the AML/CFT legal or regulatory requirements. }\end{array}$ \\
\hline
\end{tabular}




\begin{tabular}{|c|c|}
\hline EC8 & $\begin{array}{l}\text { The supervisor must be satisfied that banks have: } \\
\text { the relevant risk management policies, processes and controls. The supervisor must } \\
\text { have access to their reports; } \\
\text { management level, and appointed a relevant dedicated officer to whom potential } \\
\text { abuses of the bank's financial services (including suspicious transactions) shall be } \\
\text { reported; } \\
\text { adequate screening policies and processes to ensure high ethical and professional } \\
\text { standards when hiring staff; and } \\
\text { ongoing training programmes for their staff on KYC and methods to detect criminal and } \\
\text { suspicious activities. }\end{array}$ \\
\hline $\begin{array}{l}\text { Description and } \\
\text { findings re EC8 }\end{array}$ & $\begin{array}{l}\text { The internal controls and internal audit function as contemplated under CP } 17 \text { also } \\
\text { cover the AML/CFT measures in place. } \\
\text { By virtue of Article } 18 \text { of the Law of } 11 \text { January } 1993 \text {, "the organizations and } \\
\text { individuals subject to supervision (...) shall appoint one or more persons in charge of } \\
\text { implementation of this Law within their organization or profession. These persons shall } \\
\text { be responsible primarily with the implementation of the measures and procedures } \\
\text { referred to in Articles } 16 \text { and } 17 \text { as well as the examination of written reports prepared } \\
\text { in accordance with Article 14, § 2, so as to adopt, if necessary, measures as required } \\
\text { under Articles } 23 \text { to } 28 . " \\
\text { - According to Article } 17 \text {, second indent, of the AML/CFT Law, the institutions and } \\
\text { persons subject to that law shall introduce appropriate procedures upon recruitment } \\
\text { or appointment of their employees, or upon appointment of their representatives, to } \\
\text { verify whether they show appropriate reliability depending on the risks associated with } \\
\text { the tasks and duties to be carried out. } \\
\text { - According to Article } 17 \text {, first indent, of the AML/CFT Law, the institutions and } \\
\text { persons subject to that law shall take appropriate measures to make their employees } \\
\text { and representatives aware of the provisions of this Law. These measures include the } \\
\text { participation of their employees and representatives in special training programmes to } \\
\text { help them recognize transactions and facts that may be related to money laundering } \\
\text { or terrorist financing and to instruct them on how to proceed in such cases. }\end{array}$ \\
\hline EC9 & $\begin{array}{l}\text { The supervisor determines that banks have clear policies and processes for staff to report } \\
\text { any problems related to the abuse of the banks' financial services to either local } \\
\text { management or the relevant dedicated officer or to both. The supervisor also confirms that } \\
\text { banks have adequate management information systems to provide managers and the } \\
\text { dedicated officers with timely information on such activities. }\end{array}$ \\
\hline $\begin{array}{l}\text { Description and } \\
\text { findings re EC9 }\end{array}$ & $\begin{array}{l}\text { In addition to the text in EC8, banks are required to develop and implement adequate first } \\
\text { line (i.e., ex ante and human) monitoring and second line (i.e., ex post and automated) } \\
\text { monitoring of all transactions and business relationships allowing the detection of } \\
\text { "atypical" transactions and the filling of internal written reports to the AML/CFT officer who } \\
\text { his responsible for the analysis of these reports and the determination if transactions } \\
\text { concerned are suspicious in the sense of the law and need to be reported to the FIU. } \\
\text { In the framework of the "first line monitoring" system that banks are required to } \\
\text { implement, staff members who become aware that a transaction is atypical are required to } \\
\text { fill an internal written report to the AML/CFT officer. The latter must have access to all } \\
\text { needed information allowing him to conduct his analysis of these transactions and to } \\
\text { determine if the transaction is suspicious and if a suspicious transaction report must be }\end{array}$ \\
\hline
\end{tabular}




\begin{tabular}{|c|c|}
\hline & $\begin{array}{l}\text { filled with the FIU. } \\
\text { It was not evidenced that the supervisor had a process in place to systematically review } \\
\text { banks' policies and processes to satisfy this criterion across the banking population. }\end{array}$ \\
\hline EC10 & $\begin{array}{l}\text { Laws and regulations ensure that a member of a bank's staff who reports suspicious activity } \\
\text { in good faith either internally or directly to the relevant authority cannot be held liable. }\end{array}$ \\
\hline $\begin{array}{l}\text { Description and } \\
\text { findings re EC10 }\end{array}$ & $\begin{array}{l}\text { Article } 32 \text { of the Law of } 11 \text { January } 1993 \text { on AML/CFT explicitly provides that no civil, } \\
\text { criminal or disciplinary proceedings may be instituted nor any professional sanctions } \\
\text { imposed against persons or organizations referred to in the Law, or against their managers, } \\
\text { employees or representatives, on the basis of a suspicious transaction report to the } \\
\text { CTIF/CFI made in good faith. }\end{array}$ \\
\hline EC11 & $\begin{array}{l}\text { The supervisor is able to inform the financial intelligence unit and, if applicable, other } \\
\text { designated authority of any suspicious transactions. In addition, it is able, directly or } \\
\text { indirectly, to share with relevant judicial authorities information related to suspected or } \\
\text { actual criminal activities. }\end{array}$ \\
\hline $\begin{array}{l}\text { Description and } \\
\text { findings re EC11 }\end{array}$ & $\begin{array}{l}\text { Article } 31 \text { of the Law of } 11 \text { January } 1993 \text { on AML/CFT states that "the supervisory authorities } \\
\text { referred to in Article } 39 \text { who find in the course of inspections they perform with organizations } \\
\text { and individuals within their jurisdiction, or in any other manner, facts that could be related to } \\
\text { money laundering or terrorism financing, are required to immediately notify in writing or by } \\
\text { electronic means the Belgian Financial Intelligence Processing Unit." } \\
\text { Professional secrecy provisions imposed on the bank, its managers and its employees (see } \\
\text { the answer provided as regards principle 1.6) do not apply where they are called upon to } \\
\text { testify in court. }\end{array}$ \\
\hline EC12 & $\begin{array}{l}\text { The supervisor is able, directly or indirectly, to cooperate with the relevant domestic and } \\
\text { foreign financial sector supervisory authorities or share with them information related to } \\
\text { suspected or actual criminal activities where this information is for supervisory purposes. }\end{array}$ \\
\hline $\begin{array}{l}\text { Description and } \\
\text { findings re EC12 }\end{array}$ & $\begin{array}{l}\text { The mechanisms as regards cooperation with foreign counterparts are described in } \\
\text { paragraphs } 829-836 \text { of REM } 2005 \text {. }\end{array}$ \\
\hline \multicolumn{2}{|l|}{$\begin{array}{l}\text { Additional } \\
\text { criteria }\end{array}$} \\
\hline AC1 & $\begin{array}{l}\text { If not done by another authority, the supervisor has in-house resources with specialist } \\
\text { expertise for addressing criminal activities. }\end{array}$ \\
\hline $\begin{array}{l}\text { Description and } \\
\text { findings re } A C 1\end{array}$ & [This was not able to be fully assessed during the time of the assessment.] \\
\hline $\begin{array}{l}\text { Assessment of } \\
\text { Principle } 18\end{array}$ & Largely Compliant \\
\hline Comments & $\begin{array}{l}\text { The IMF (Mr. Richard Lalonde, Legal Department), the FATF and the Belgian delegation } \\
\text { agreed previous to the on-site visit of the assessment team that this FSAP examination } \\
\text { would not include a comprehensive assessment of the AML/CFT measures in place. These } \\
\text { measures will be assessed by the FATF against its new } 40 \text { Recommendation in the fall of } \\
\text { 2014. As agreed, the assessment of CP18 is thus based on succinct information. }\end{array}$ \\
\hline
\end{tabular}




\begin{tabular}{|c|c|}
\hline & $\begin{array}{l}\text { Several criteria in Principle } 18 \text { require the supervisor to confirm that banks have sufficient } \\
\text { controls and systems in place for preventing, identifying and reporting potential abuses of } \\
\text { financial services, including money laundering etc. It was not sufficiently evidenced that the } \\
\text { supervisor had a systematic process to verify adequacy of risk management across the } \\
\text { population of banks. }\end{array}$ \\
\hline Principle 19 & $\begin{array}{l}\text { Supervisory approach. An effective banking supervisory system requires that supervisors } \\
\text { develop and maintain a thorough understanding of the operations of individual banks and } \\
\text { banking groups, and also of the banking system as a whole, focusing on safety and } \\
\text { soundness, and the stability of the banking system. }\end{array}$ \\
\hline \multicolumn{2}{|r|}{ t } \\
\hline $\mathrm{EC1}$ & $\begin{array}{l}\text { The supervisor has policies and processes in place to develop and maintain a thorough } \\
\text { understanding of the risk profile of individual banks and banking groups. }\end{array}$ \\
\hline $\begin{array}{l}\text { Description and } \\
\text { findings re EC1 }\end{array}$ & $\begin{array}{l}\text { The NBB employs a Supervisory Review and Evaluation Process (SREP) which is a } \\
\text { comprehensive system building on multiple inputs to assess the risk profile of an institution } \\
\text { and to determine the appropriate supervisory actions that should flow from that analysis. } \\
\text { The SREP builds on a range of information inputs which include: } \\
\text { - direct supervisory reporting from the firm; } \\
\text { - } \quad \text { direct supervisory contit institution's Internal Capital Adequacy Assessment Process (ICAAP); } \\
\text { The SREP focuses on the institution's exposure to risks, the adequacy of an institution's } \\
\text { risks identification, measure and monitoring processes, the adequacy of an institution's } \\
\text { own funds and capital resources, and compliance with prudential regulations and } \\
\text { requirements. Quantitative and qualitative assessment of risks as well as their management } \\
\text { by institutions are an essential component of the SREP. Analysis of all risk components is } \\
\text { supported by a structured "scorecarding" approach (see EC3). } \\
\text { On the basis of the analysis of the scorecard, the ICAAP and stress tests the NBB concludes } \\
\text { on a final assessment of the firm's risk profile and devises the supervisory actions that are } \\
\text { needed including the capital decision for the entity or group. In the case of groups that are } \\
\text { active within the EU there will be joint decisions made on the capital adequacy of the group } \\
\text { and its component entities as required by the CRD (2006/48/EC as revised). Of the four } \\
\text { systemic firms in Belgium, the NBB is the host supervisor of two and the home supervisor } \\
\text { for two. } \\
\text { The assessors discussed the process, reviewed documents, which illustrated the process } \\
\text { and discussed the supervisory process with individual banks. }\end{array}$ \\
\hline EC2 & $\begin{array}{l}\text { The supervisor monitors and assesses trends, developments and risks for the banking } \\
\text { system as a whole. The supervisor also takes into account developments in non-bank } \\
\text { financial institutions through frequent contact with their regulators. }\end{array}$ \\
\hline $\begin{array}{l}\text { Description and } \\
\text { findings re EC2 }\end{array}$ & $\begin{array}{l}\text { A global assessment of risks and trends for the banking sector is carried out and is mainly } \\
\text { performed by the Prudential Policy and Financial Stability department. Regular horizontal } \\
\text { analysis is performed on various risks and issues (such as liquidity risks, capital, market risks }\end{array}$ \\
\hline
\end{tabular}


or business models). These analyses are also supported by peer reviews when data are available. Example of recent studies are: sovereign risks (global risk, solvency by comparing PDs and LGD of banks for these exposures, accounting methods), credit risks and in particular corporate risks and interest rate risks. These analyses are regularly presented to the NBB Board, which decides upon policy actions if risks are considered to be significant. These horizontal analyses complement the vertical analysis performed by the operational department, which aims at assessing the risk of individual institution.

Furthermore, the internal NBB architecture has developed a broader framework for risk assessment through the introduction (July 2011) of two new committees - the Risk Committee and Macro-Financial Committee. The objective of the new committees is to enhance the quality of the risk based dimension of supervision by taking into account the macro and micro dimension and their interaction.

The main objectives of the Risk Committee are to: (i) provide the Board with advice on relevant regulatory and supervisory issues; (ii) foster cooperation and create synergies among the prudential departments, by directing or steering the analysis of horizontal teams and (iii) provide horizontal analysis on different risks such as liquidity, accounting or solvency (based on input from the risk teams). The RC also acts as a key point between the Board and the risk teams of experts, which have been created within the prudential departments, and the RC can act as a "project manager" for longer term projects (additional monitoring tools are being developed).

The Macro-Financial Committee (MFC) seeks to foster the interaction and the synergies between the core central bank activities of the NBB and supervision. In particular, the objectives of the Macro-financial Committee are (i) to enhance the cooperation and create synergies in the field of macro-prudential surveillance among different NBB departments, in particular, Research, Statistics, Financial Markets and prudential policy department, the department of microeconomic information and International and Eurosystem Coordination; (ii) to enhance the exchange of information in particular on macro-financial development on a cross border basis with jurisdictions, which are of particular relevance to Belgian financial institutions and on issues, which may affect financial stability; and (iii) to provide the Risk Committee and the Board of Directors with information on new macro-financial risks and suggest areas of future analysis.

Analysis and risks identified in the MFC are communicated to the prudential departments, for example regular country analyses. While it is recognized that it can be very challenging to translate analysis of the macro-environment into concrete policy actions, this is the objective of the MFC. To date there have been tangible outputs from the MFC in a number of areas, such as stress testing of specific risks, country exposures and business models.

Working together, the common objectives of the RC and MFC are to determine, each year, the main risks to financial stability, which need to be analyzed by the prudential departments (in essence a "top-down" prioritization). This objective is the newly introduced annual "Risk Review." Issues, which have been identified for the coming year include: real estate, liquidity, interest rates, slow growth. Secondly the committees are to develop macro-prudential policies.

The main trends, developments and risks of the Belgian financial system are summarized in the NBB's annual Financial Stability Review. 


\begin{tabular}{|c|c|}
\hline & $\begin{array}{l}\text { Discussion with NBB staff indicated that the introduction of the RC and MFC had been } \\
\text { valuable in identifying issues that previously would not have surfaced in a timely manner. }\end{array}$ \\
\hline EC3 & $\begin{array}{l}\text { The supervisor uses a methodology for determining and assessing on an ongoing basis the } \\
\text { nature, importance and scope of the risks to which individual banks or banking groups are } \\
\text { exposed. The methodology should cover, inter alia, the business focus, the risk profile and } \\
\text { the internal control environment, and should permit relevant comparisons between banks. } \\
\text { Supervisory work is prioritized based on the results of these assessments. }\end{array}$ \\
\hline $\begin{array}{l}\text { Description and } \\
\text { findings re EC3 }\end{array}$ & 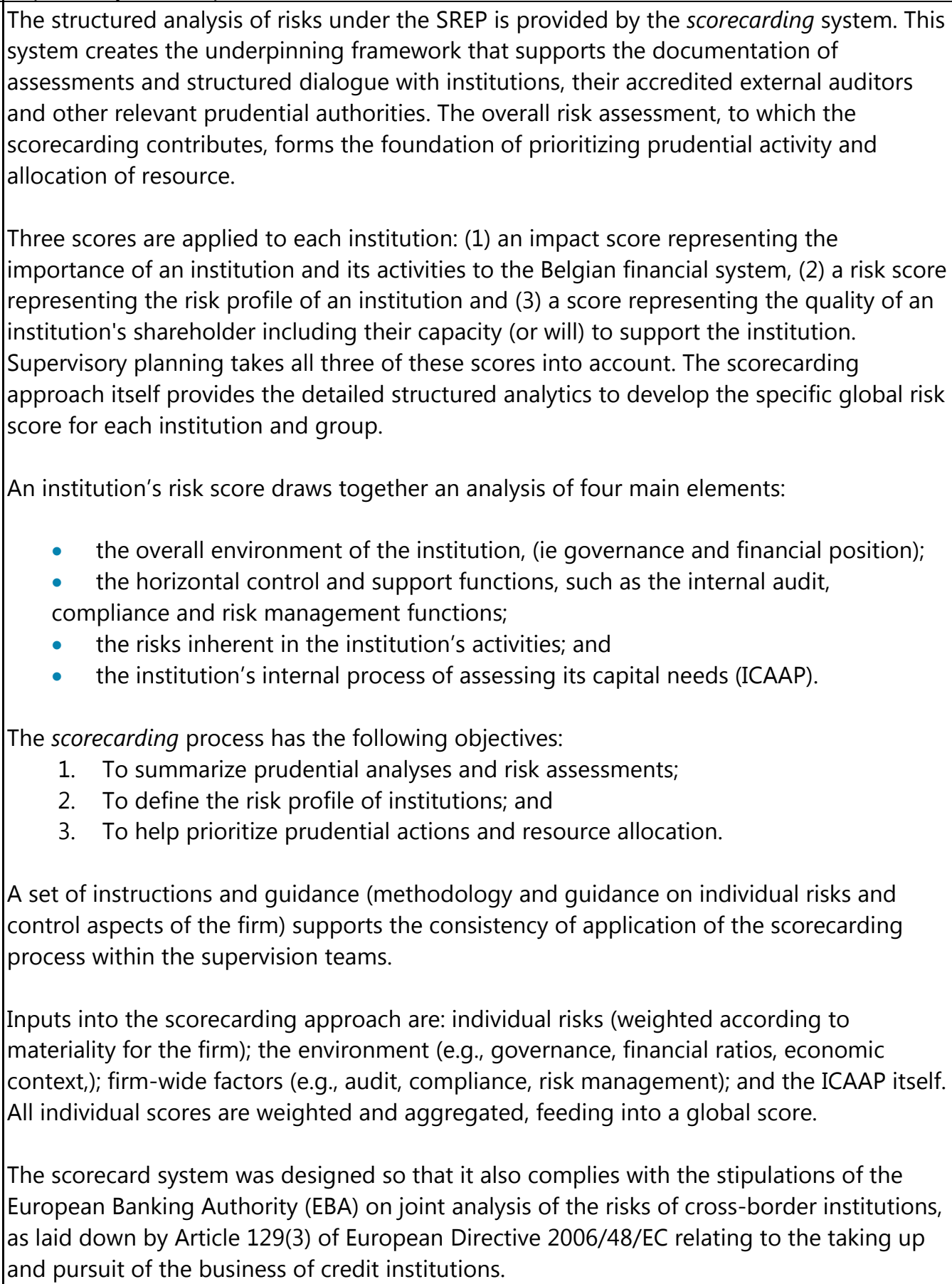 \\
\hline
\end{tabular}




\begin{tabular}{|c|c|}
\hline & $\begin{array}{l}\text { A scoring scale covering both quantitative assessment of the level of risks and qualitative } \\
\text { aspects of the quality of management control is applied. If the level of risk or quality of } \\
\text { control is, for some reason, unknown, it is assigned a level " } 3 \text { " score, which could trigger } \\
\text { prudential actions to remedy the lack of information. } \\
\text { There is an annual validation process before the information contained in the scorecarding } \\
\text { system is archived (at this point it is a historical, point in time, reference for the risk profile } \\
\text { of the institution) and the next scorecard is opened. Indeed the next scorecard cannot be } \\
\text { opened until the previous one has been validated and archived. The validation process } \\
\text { takes place at the end of the calendar year and involves peer group checking at peer group } \\
\text { and divisional level (ie more than one layer of hierarchy) to obtain a clear view on } \\
\text { consistency of approach. } \\
\text { Together with the review of the ICAAP and stress tests, the output of the scorecarding } \\
\text { process feeds into the overall risk assessment of the institution and is the basis on which } \\
\text { supervisory actions will be determined and planned. Within the EU joint decisions are now } \\
\text { made for the capital adequacy of groups and the individual solo entities within the group. } \\
\text { The final capital decision must be approved by the NBB board. In the context of the joint } \\
\text { EU decision making process, the various competent authorities are encouraged to reach a } \\
\text { joint decision. This means that the overall group decision is made by the NBB for } \\
\text { consolidated groups. In these scenarios, a member state with an incorporated entity always } \\
\text { has the right to make the final decision, even if not agreed by the college. However, the EU } \\
\text { directives have created mediation mechanisms and also introduced a requirement to have } \\
\text { regard to the impact of an individual capital decision on the stability of other group entities } \\
\text { and neighboring jurisdictions. }\end{array}$ \\
\hline EC4 & $\begin{array}{l}\text { The supervisor confirms banks' and banking groups' compliance with prudential } \\
\text { regulations and other legal requirements. }\end{array}$ \\
\hline $\begin{array}{l}\text { Description and } \\
\text { findings re EC4 }\end{array}$ & $\begin{array}{l}\text { This confirmation is performed in the context of the SREP, which as noted in EC1 has a } \\
\text { range of inputs, including both off-site assessment and focused on-site activity with the } \\
\text { supervised institutions. A major component of supervisory assessment of prudential and } \\
\text { legal compliance is the annual submission of the institution's self assessment of the quality } \\
\text { of its internal controls. (Note that the external auditors must give an opinion on the } \\
\text { completeness and accuracy of this report - please see CP17 and EC1 of CP20). }\end{array}$ \\
\hline EC5 & $\begin{array}{l}\text { The supervisor requires banks to notify it of any substantive changes in their activities, } \\
\text { structure and overall condition, or as soon as they become aware of any material adverse } \\
\text { developments, including breach of legal or prudential requirements. }\end{array}$ \\
\hline $\begin{array}{l}\text { Description and } \\
\text { findings re EC5 }\end{array}$ & $\begin{array}{l}\text { The NBB expects all institutions to promptly notify its supervisory contacts should major } \\
\text { developments emerge or be contemplated. Indeed a substantive change in activities (for a } \\
\text { systemic firm) would require approval as a strategic decision and the NBB would expect to } \\
\text { be made aware of such changes to ensure the firm remained in compliance with Article } 20 \\
\text { of the Banking Law. In addition, the external auditors are expected to alert the NBB should } \\
\text { they become aware of any material breach of regulation or adverse change (please see also } \\
\text { EC1 of (P20). }\end{array}$ \\
\hline EC6 & $\begin{array}{l}\text { The supervisor has an adequate information system, which facilitates the processing, } \\
\text { monitoring and analysis of prudential information. The system aids the identification of } \\
\text { areas requiring follow-up action. }\end{array}$ \\
\hline
\end{tabular}




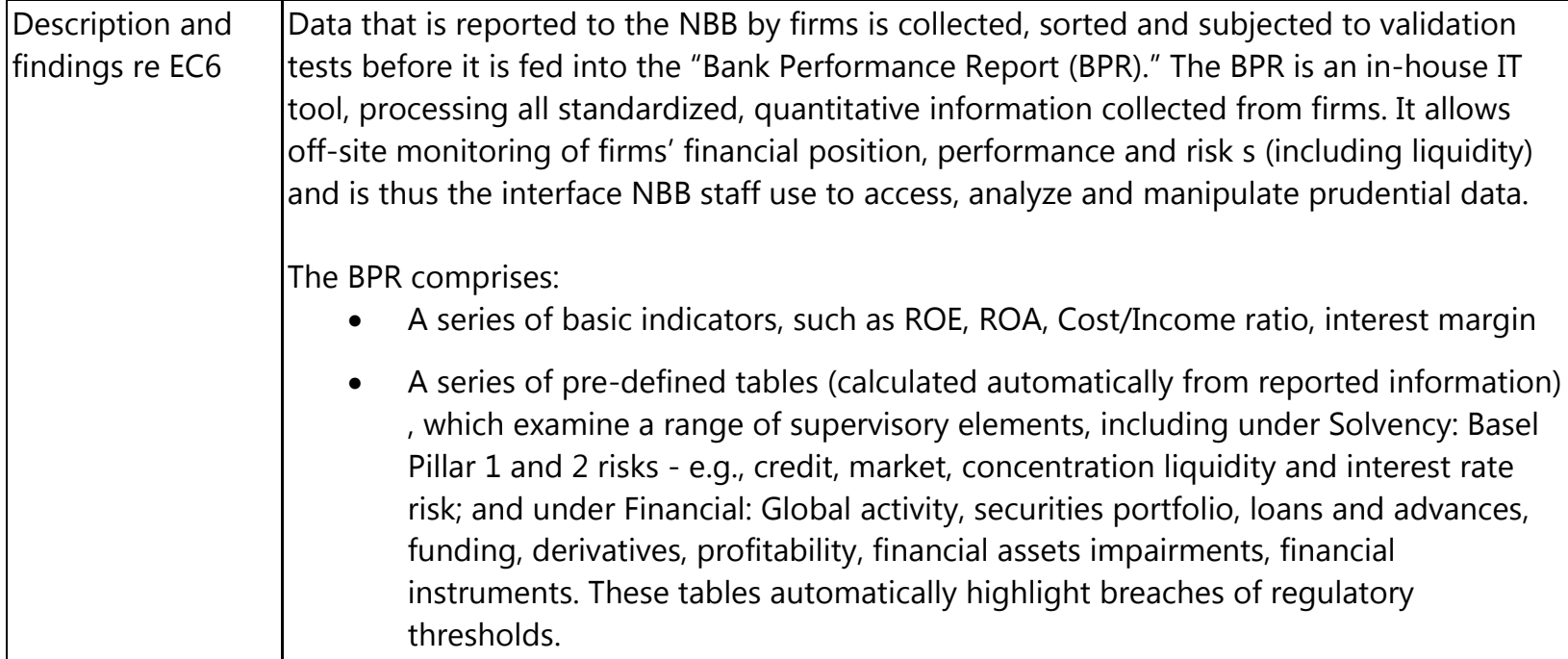

- A series of basic indicators, such as ROE, ROA, Cost/Income ratio, interest margin

- A series of pre-defined tables (calculated automatically from reported information) , which examine a range of supervisory elements, including under Solvency: Basel Pillar 1 and 2 risks - e.g., credit, market, concentration liquidity and interest rate risk; and under Financial: Global activity, securities portfolio, loans and advances, funding, derivatives, profitability, financial assets impairments, financial instruments. These tables automatically highlight breaches of regulatory thresholds.

- Pre-defined dashboard, providing an overall picture of the firm with key figures on performance, financial and solvency

The BPR system permits analysis by entity, by risk, by peer group, over time (identifying trends or new developments) and a considerable degree of flexible manipulation of data is possible. Be-spoke templates can be created by staff using Excel to create ad hoc analysis or reports and such templates can be saved.

There is a shared ("ecorporate") database for banks, their external auditors and the NBB, which houses a number of qualitative reports such as the external auditor reports, the internal control reports and information on the quality of shareholders. This shared database provides an easy monitoring tool to ensure that the reports held are updated in a timely manner.

The Scorecarding database contains all the files (solo and consolidated basis) of firms' individual scorecards. The database receives an automatic feed of prudential data that updates the quantitative components of the relevant risk cards and which proposes a risk score. The analyst can over-ride this score but should provide justifications for doing so (such information is input and held within the data base).

The database is flexible and can be interrogated for peer analysis or for the update and analysis of an individual entity. In other words, the scorecarding application can produce bespoke reporting documents to provide feedback on the risk profile of a given institution for a peer group or industry sectoral group. Equally, the database can deliver "global" assessment card or individual assessment cards (by risk element/theme). Finally, the scorecarding application produces a benchmark table.

The scorecarding application does not provide an automatic prompt for regular updating, although the date at which a scorecard was last refreshed is held on the system. It is intended that scorecards should be updated regularly and at the very least in preparation for a major supervisory activity such as college of supervisor work on a joint capital assessment, or following an on-site inspection by NBB staff. 


\begin{tabular}{|c|c|}
\hline & $\begin{array}{l}\text { A dashboard has recently been designed in order to provide an overview of an institution's } \\
\text { risk profile, its position amongst its peers and the wider industry. } \\
\text { The existing supervisory tools provide considerable scope for a wide range of information } \\
\text { to be interrogated both on a horizontal view across the system at a point in time or for a } \\
\text { more "through time" historical analysis for trend analysis. However, the } \\
\text { NBB has identified a number of enhancements to its supervisory tools, which it wishes to } \\
\text { put in place. To this end it has embarked on a program ("PRIME") with a range of key } \\
\text { projects including in particular, "Risk profiles" the next generation scorecarding (new IT } \\
\text { environment but also more advanced analytical underpinning) and the development of a } \\
\text { "Macrodashboard" which will better integrate micro and macro prudential data. } \\
\text { Additionally the project will make the NBB ready for and support the integration of new } \\
\text { reporting required by the incoming changes to regulation of CRD4 and Solvency } 2 \text {. }\end{array}$ \\
\hline \multicolumn{2}{|l|}{$\begin{array}{l}\text { Additional } \\
\text { criteria }\end{array}$} \\
\hline $\mathrm{AC1}$ & $\begin{array}{l}\text { The supervisor employs a well defined methodology designed to establish a forward- } \\
\text { looking view on the risk profile of banks, positioning the supervisor better to address } \\
\text { proactively any serious threat to the stability of the banking system from any current or } \\
\text { emerging risks. }\end{array}$ \\
\hline $\begin{array}{l}\text { Description and } \\
\text { findings re } A C 1\end{array}$ & $\begin{array}{l}\text { Although there are no specific "forward looking" or "early warning" indicators, the } \\
\text { methodologies and processes mentioned above under EC1 to EC3 are intended to provide } \\
\text { a forward-looking perspective upon which pro-active supervision can be built, for example } \\
\text { by seeking to pay attention to the development of trends (in risk exposure and } \\
\text { management control). }\end{array}$ \\
\hline $\begin{array}{l}\text { Assessment of } \\
\text { Principle } 19\end{array}$ & Compliant \\
\hline Comments & $\begin{array}{l}\text { The supervisory staff of the NBB are conducting an excellent quality of supervision. Staff } \\
\text { demonstrated a strong command of their portfolios, a view which was reinforced by the } \\
\text { banks the Assessors met with. A sample review of analyses and reports by the NBB } \\
\text { supervisors indicated that thorough and professional work is being undertaken. } \\
\text { Supervisory resource is allocated on a risk based principle taking into account three key } \\
\text { factors: the impact of failure of a firm, the risk of failure of a firm and the strength of } \\
\text { potential shareholder support. A sound analytical framework to understand the risks of the } \\
\text { institutions, ie the risk of failure, is in place (the scorecarding methodology). This } \\
\text { methodology distinguishes between an assessment of the inherent risk and the quality of } \\
\text { the management or control of that risk. This approach represents best practice. } \\
\text { Nevertheless, in order to better differentiate the degree of risk in the institutions, the NBB } \\
\text { is looking to develop its risk analytics more deeply in two particular dimensions. First, to } \\
\text { improve the quality of risk analysis itself topic by topic (whether, for example, interest rate } \\
\text { risk in the banking book or strategic risk) and upgrade the guidance available to the } \\
\text { supervisors to assist their risk assessment. Secondly, upgrading of the IT system as part of } \\
\text { the "PRIME" project will permit an even more flexible interrogation of the data held in the } \\
\text { system and may promote a more systematic approach to updating the scorecard } \\
\text { assessments following any supervisory action or interaction with the institution. Both of } \\
\text { these developments have the scope to assist in making the NBB risk approach more } \\
\text { forward looking and its supervisory planning more effective. }\end{array}$ \\
\hline
\end{tabular}




\begin{tabular}{|c|c|}
\hline & $\begin{array}{l}\text { It was noted that the global risk assessments for group included insurance risk (for groups } \\
\text { where this was relevant). This finding was encouraging as this approach is not yet standard } \\
\text { in all supervisory authorities. As yet there is no systematic scorecarding underpinning this } \\
\text { analysis, but this is planned. Enhancements in the integration of the insurance dimension in } \\
\text { the group assessment will be important and the NBB is urged to make progress. }\end{array}$ \\
\hline Principle 20 & $\begin{array}{l}\text { Supervisory techniques. An effective banking supervisory system should consist of on-site } \\
\text { and off-site supervision and regular contacts with bank management. }\end{array}$ \\
\hline Essential criteria & \\
\hline EC1 & $\begin{array}{l}\text { The supervisor employs an appropriate mix of on-site and off-site supervision to evaluate } \\
\text { the condition of banks, their inherent risks, and the corrective measures necessary to } \\
\text { address supervisory concerns. The specific mix may be determined by the particular } \\
\text { conditions and circumstances of the country. The supervisor has policies and processes in } \\
\text { place to assess the quality, effectiveness and integration of on-site and off-site functions, } \\
\text { and to address any weaknesses that are identified. }\end{array}$ \\
\hline $\begin{array}{l}\text { Description and } \\
\text { findings re } E C 1\end{array}$ & 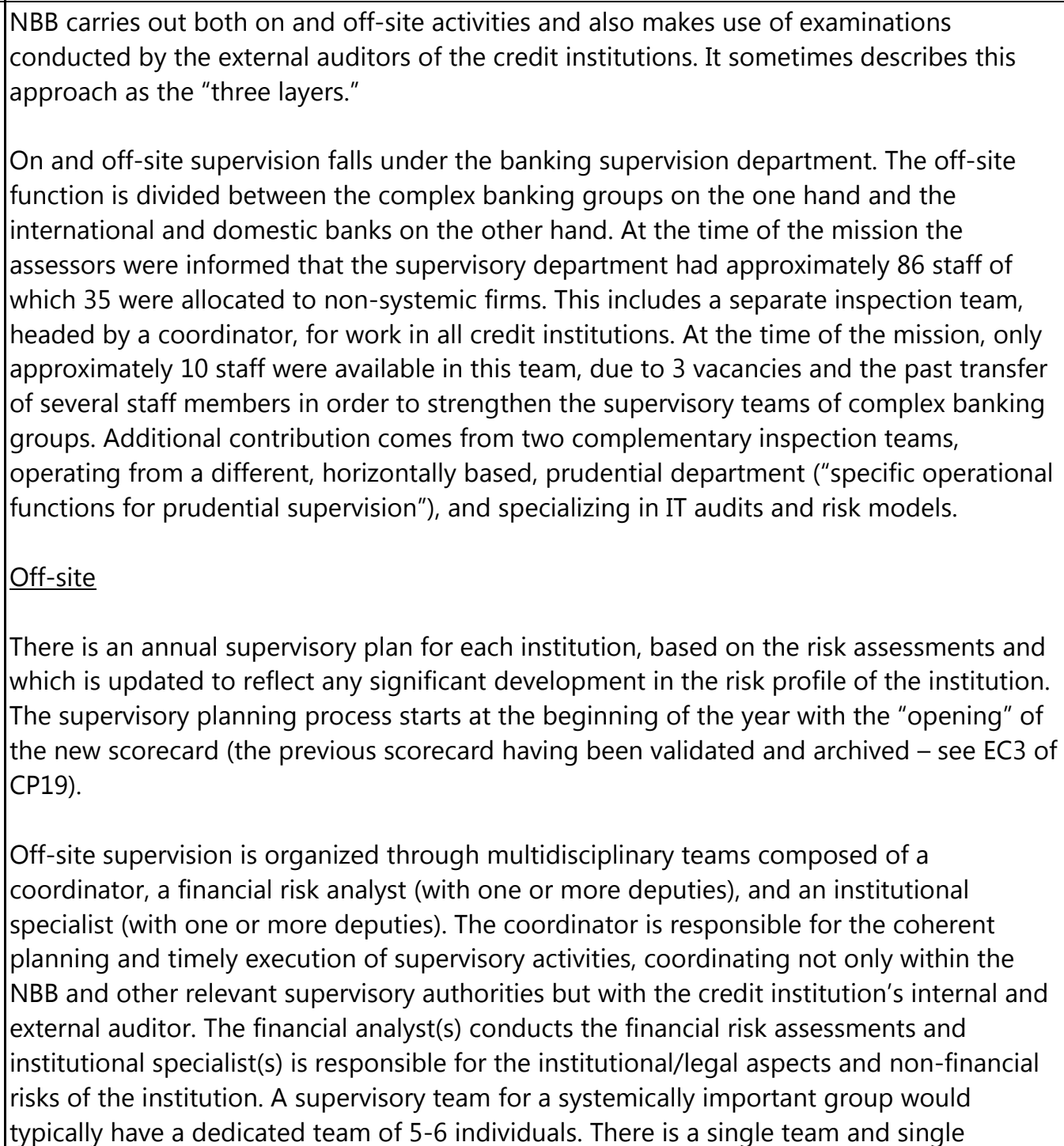 \\
\hline
\end{tabular}


coordinator for the systemically important institutions, but the mid-size and smaller institutions will not have dedicated teams. In this case each supervised institution will have a designated point of contact within the supervisory team.

The off-site team is responsible for the financial analysis of the institution. A "quick look" financial analysis is required quarterly for all firms and a full (ie extensive) analysis is required at least 6 monthly for systemic firms and at least annually for non-systemic firms.

While the multidisciplinary teams mainly work off-site they also have regular discussions mainly on-site with bank management, reflecting the nature, importance and sensitivity of the issue. Periodic contact are maintained with the chief financial and risk officers of the banks, as well as with the compliance function. The frequency of the contacts depends on the size and systemic importance of the financial institution. For the systemically significant firms, the NBB will hold quarterly meetings with main risk functions in the group management and at least annual contact with the board of the institution and with the internal audit function. In addition, the supervisory team for all firms will regularly meet with the accredited external auditor and the internal auditor of each bank.

On-site

The on-site function is separate from the off-site function and has dedicated full-time examiners, headed by a coordinator, who rotate between institutions in order to promote consistency of approach across the system and to promote independence of approach. The on-site team was separated out from the supervisory teams following a management decision of the NBB in July 2011.

An annual inspection plan is drawn up - at the start of the year - on the basis of the needs of the specific supervisory teams and as demand exceeds supply, the allocation of resource has to balance the needs of firm specific risk based priorities with the need to ensure a regular periodic on-site inspection for all firms. The topics of the missions are identified by the off-site teams as a result of their supervisory analysis but the detailed design of the mission is determined by the inspectors.

\section{Auditors}

The Banking Law (Article 55) places an obligation on banks' external auditors to cooperate with the supervision carried out by the NBB and as such the external auditor plays an key role in the overall supervisory approach. The law further provides (Articles 51-54) that the auditor is subject to prior accreditation by the NBB, is obliged to co-operate with the NBB and must act also as the statutory auditor.

In practice (and as set out in a regulatory Circular), the external auditors' role is to:

- Periodically confirm the accuracy and completeness of prudential reporting;

- Give an opinion on the quality of the bank's organization and internal control;

- Check compliance with applicable laws and regulations;

- Submit, when required, special reports on specific issues and situations;

- Provide a timely report of any material breach of regulation or adverse change of which they become aware.

The assessors reviewed several examples of on-site and off-site action plans, alerts, analysis and risk assessments. They also discussed with NBB staff how the off-site and on-site programs operate together, in particular the coordination through the supervisory team meetings that review progress on supervisory actions for an institution. When an onsite 


\begin{tabular}{|c|c|}
\hline & $\begin{array}{l}\text { inspection has taken place the inspector will continue to participate in the team meeting } \\
\text { until all recommendations arising from the on-site visit have been satisfactorily concluded. } \\
\text { It is the on-site inspector who decides on when the outstanding issues can be signed off. }\end{array}$ \\
\hline $\mathrm{EC2}$ & $\begin{array}{l}\text { The supervisor has in place a coherent process for planning and executing on-site and off- } \\
\text { site activities. There are policies and processes in place to ensure that such activities are } \\
\text { conducted on a thorough and consistent basis with clear responsibilities, objectives and } \\
\text { outputs, and that there is effective coordination and information sharing between the on- } \\
\text { site and off-site functions. }\end{array}$ \\
\hline $\begin{array}{l}\text { Description and } \\
\text { findings re EC2 }\end{array}$ & 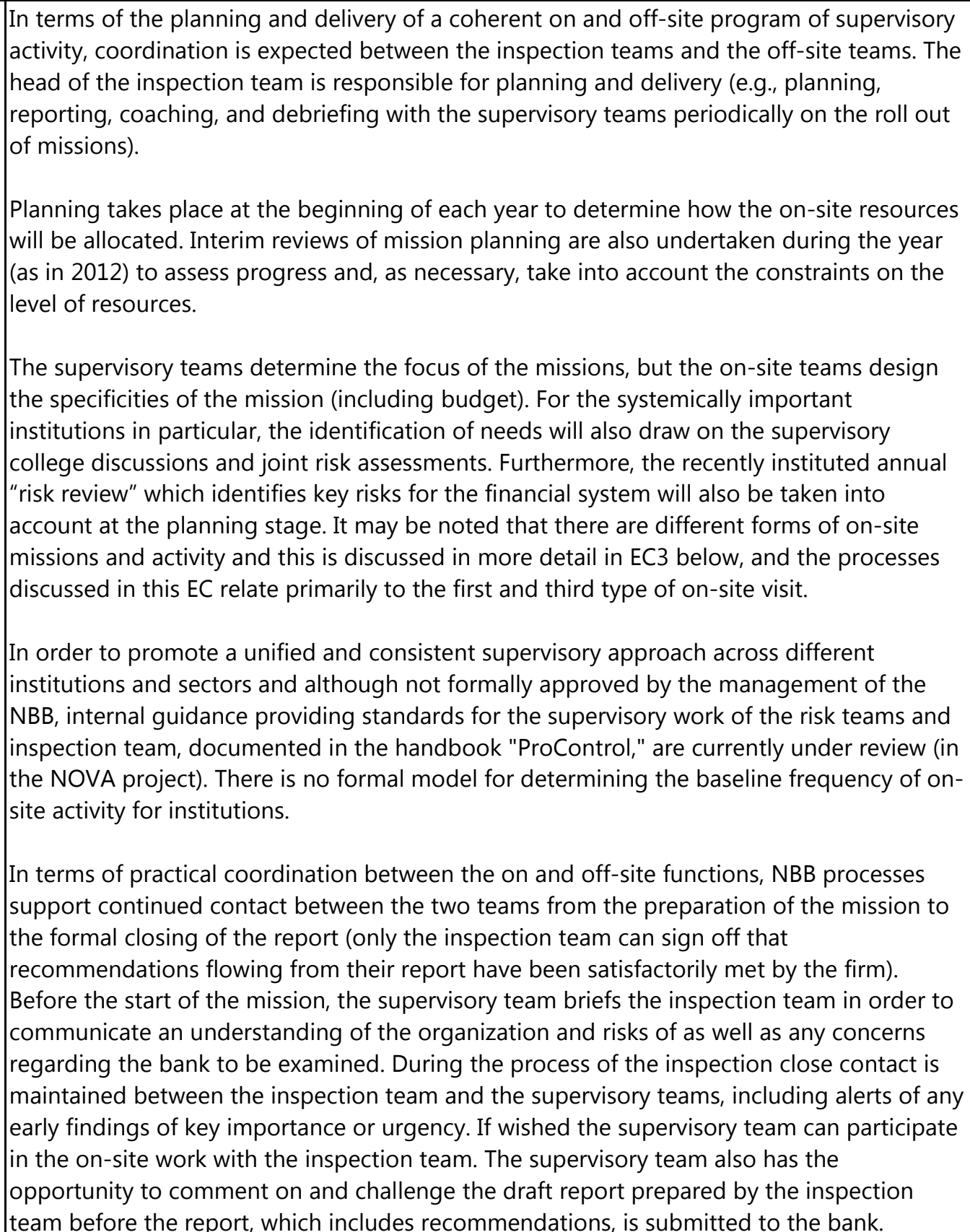 \\
\hline
\end{tabular}




\begin{tabular}{|c|c|}
\hline & $\begin{array}{l}\text { The follow up process after the inspection report is jointly managed between the } \\
\text { inspection team and the supervisory team: the inspection team takes the lead in assessing } \\
\text { the action plan submitted by the bank in response to the examination report while the } \\
\text { supervisory team is responsible for following up the effective implementation of any } \\
\text { corrective measures. As noted above, the report is not considered to be closed and } \\
\text { completed until the recommendations arising from the report have been acted upon by } \\
\text { the institution to the satisfaction of the inspection team and the inspection team will } \\
\text { continue to participate in the formal supervisory team meetings until the inspection report } \\
\text { is closed. }\end{array}$ \\
\hline EC3 & $\begin{array}{l}\text { On-site work, conducted either by the supervisor's own staff or through the work of } \\
\text { external experts, is used as a tool to: } \\
\text { - } \text { provide independent verification that adequate corporate governance (including } \\
\text { risk management and internal control systems) exists at individual banks; } \\
\text { - determine that information provided by banks is reliable; } \\
\text { obtain additional information on the bank and its related companies needed for } \\
\text { the assessment of the condition of the bank, the evaluation of material risks, and } \\
\text { the identification of necessary remedial actions and supervisory actions, including } \\
\text { enhanced off-site monitoring; and } \\
\text { monitor the bank's follow-up on supervisory concerns. }\end{array}$ \\
\hline $\begin{array}{l}\text { Description and } \\
\text { findings re EC3 }\end{array}$ & $\begin{array}{l}\text { The NBB distinguishes between four main kinds of on-site examinations: } \\
\text { 1. Deep dive inspections: based on risk assessment of the bank and planned in an } \\
\text { annual action plan (revised quarterly). } \\
\text { 2. Thematic inspections: based on macroprudential and sectoral analyses, essentially } \\
\text { aimed at peergroup benchmarking, explaining outliers, exploring evolutions in } \\
\text { new risk types, or focusing on specific areas such as AML. } \\
\text { 3. Inspections targeting specific issues or in reaction to specific information (crisis } \\
\text { management, fraud). } \\
\text { 4. On-site information gathering: on-site visits aiming at updating the supervisory } \\
\text { information and assessment of the bank, its activities and risk management. } \\
\text { In other words, on-site missions can be very comprehensive in scope or highly targeted. } \\
\text { Missions might be conducted due to a need to conduct a thematic horizontal investigation } \\
\text { in the sector or alternatively in response to the risk assessment of the individual institution. } \\
\text { For complex groups there are likely to be targeted missions to examine specific issues (e.g., } \\
\text { risk management, valuation models); thematic missions (e.g., liquidity, e.g., quality of } \\
\text { reporting or dealing rooms) and missions driven by the risk assessment of the individual } \\
\text { institution. For other groups (domestic and international banks) prioritization is carried out } \\
\text { on the basis of clustering analysis, on a multi-year planning cycle, thematic missions (e.g., } \\
\text { interest rate risk, liquidity risk) or missions driven by issues identified during the risk } \\
\text { analysis/scorecarding process. } \\
\text { The most recurrent topics examined during an on-site examination are: internal } \\
\text { governance, control functions (internal audit, compliance, risk management), qualitative } \\
\text { and quantitative assessment of interest rate risk, credit risk, market risk, liquidity risk, } \\
\text { operational risk, derivatives, ICAAP, supervision of commercial networks. On-site missions } \\
\text { can be used to verify the reliability of prudential and other data that is submitted but the } \\
\text { NBB more typically looks to the verification of financial data (including prudential data) } \\
\text { performed by the external auditors as formally, twice a year, the accuracy and } \\
\text { completeness of the data is confirmed by the external auditors. }\end{array}$ \\
\hline
\end{tabular}




\begin{tabular}{|c|c|}
\hline & $\begin{array}{l}\text { Broadly speaking, missions which were finalized in } 2012 \text { (a number of which began in 2011) } \\
\text { were divided evenly between those focuses on the systemic firms and those focused on the } \\
\text { international and domestic banks. Topics under consideration included control } \\
\text { environment (internal controls, risk management, compliance), specific risk focused } \\
\text { inspections (e.g., market risk, ALM). } \\
\text { The NBB has also concluded, as an output of internal management review mid 2012, that } \\
\text { moving forward it was important for inspections to be more risk focused, to put greater } \\
\text { emphasis on testing, to be more focused in the specification of the mission and for reports } \\
\text { to provide a greater indication of work carried out on site. These new management } \\
\text { expectations and guidelines have already been put into place. } \\
\text { The assessors reviewed samples of on-site reports. }\end{array}$ \\
\hline EC4 & $\begin{array}{l}\text { Off-site work is used as a tool to: } \\
\text { regularly review and analyse the financial condition of individual banks using } \\
\text { prudential reports, statistical returns and other appropriate information, including } \\
\text { publicly available information; } \\
\text { - follow up on matters requiring further attention, evaluate developing risks and } \\
\text { help identify the priorities and scope of further work; and } \\
\text { - help determine the priorities and scope of on-site work. }\end{array}$ \\
\hline $\begin{array}{l}\text { Description and } \\
\text { findings re EC4 }\end{array}$ & $\begin{array}{l}\text { Off-site work is used to assess financial and institutional risk for each credit institution. } \\
\text { The off-site teams conduct a regular risk assessment and report the analysis and findings to } \\
\text { the supervisory team and management of the NBB, for discussion. Each institution will be } \\
\text { assessed on an annual basis at a minimum (as required by EU law) but this can be more } \\
\text { frequent. Typically for institutions assessed in colleges there will be at least } 6 \text { monthly } \\
\text { updates. } \\
\text { Off-site work is based on: } \\
\text { Analysis of a range of data notably including (but not limited to) prudential returns } \\
\text { (many of which are subject to OLAP ("on line analytical processing') which provides } \\
\text { standard analysis, trends and peer group comparisons), ICAAP submission, } \\
\text { published financial reports, reports from external auditors, annual management } \\
\text { reports on internal controls, compliance } \\
\text { On-site inspection reports } \\
\text { Horizontal and thematic inputs and reviews conducted by the NBB } \\
\text { Meetings with the institutions, which in addition to regular contact with } \\
\text { management will include contact with finance, risk management (frequency } \\
\text { proportionate to size and systemic nature of institution); annual meetings with the } \\
\text { internal and external auditor } \\
\text { When the analysis is performed, reports are made to the supervisory team and the } \\
\text { management of the NBB, for discussion, to feed into the scorecarding approach (see CP19), } \\
\text { the identification of the risk profile, and the determination of the priorities for the annual } \\
\text { supervisory including remedial measures if necessary. } \\
\text { The assessors reviewed samples of on-site reports and assessments. }\end{array}$ \\
\hline
\end{tabular}




\begin{tabular}{|c|c|}
\hline EC5 & $\begin{array}{l}\text { Based on the risk profile of individual banks, the supervisor maintains sufficiently frequent } \\
\text { contacts as appropriate with the bank's Board, non-executive directors, Audit Committee } \\
\text { and senior and middle management (including heads of individual business units and } \\
\text { control functions) to develop an understanding of and assess such matters as strategy, } \\
\text { group structure, corporate governance, performance, capital adequacy, liquidity, asset } \\
\text { quality and risk management systems. }\end{array}$ \\
\hline $\begin{array}{l}\text { Description and } \\
\text { findings re EC5 }\end{array}$ & $\begin{array}{l}\text { Contacts with bank management, at all relevant levels, are scheduled as part of the annual } \\
\text { supervisory plan for the individual institution. The objective is to have at least one } \\
\text { comprehensive discussion at the highest management level a year with all banks. } \\
\text { As a general principle the level at which contacts with banks take place depends largely on } \\
\text { the nature, importance and sensitivity of the issue. For the systemically important banks, } \\
\text { more regular contacts with the bank management are planned: there are quarterly } \\
\text { discussions with the chief financial officers and the chief risk officers of the banks as well as } \\
\text { bi-annual meetings with the compliance officer. In addition, regular meetings with the } \\
\text { management or staff of the bank are organized in light of the follow-up of on-site } \\
\text { inspections or other supervisory actions. } \\
\text { For the most significant, ie systemic, firms, the NBB management will have direct contact } \\
\text { with Board members, including non executive directors, on a formal and informal basis. In } \\
\text { principle the head of supervision of the prudential department for banking supervision will } \\
\text { meet the executive management of the systemic and mid-size banks at least annually. It is } \\
\text { standard practice for the NBB to meet the chair of the audit committee. The systemic firms } \\
\text { with whom the assessors had meetings confirmed that the NBB maintained a regular } \\
\text { contact with them, both through on-site presence and meetings at management level. The } \\
\text { records of supervisory activity for large and mid size firms confirm that there is a consistent } \\
\text { pattern of meeting between the NBB and these categories of firms. }\end{array}$ \\
\hline EC6 & $\begin{array}{l}\text { On an ongoing basis during on-site and off-site supervisory activities, the supervisor } \\
\text { considers the quality of the Board and management. }\end{array}$ \\
\hline $\begin{array}{l}\text { Description and } \\
\text { findings re EC6 }\end{array}$ & $\begin{array}{l}\text { The assessment of the quality of governance and management is one of the basic } \\
\text { components of the annual assessment exercise made by the team: the quality of the Board } \\
\text { and management is assessed in the yearly scorecarding approach (the quality of } \\
\text { governance and of management control is subject to separate analysis). } \\
\text { The on and off-site functions will have periodic meetings and discussions with the Board } \\
\text { and management through the year. Irrespective of the focus of an on-site mission, the } \\
\text { inspectors will open and close the examination with meetings with the executive } \\
\text { management. Supporting information is gathered including the allocation of tasks between } \\
\text { the different members of the management committee of the bank, and the minutes of the } \\
\text { meetings of the supervisory and management bodies (Board of Directors, Audit } \\
\text { Committee, Executive Board) and the establishment of the committees of the Board (e.g., } \\
\text { audit, remuneration, risk management). }\end{array}$ \\
\hline EC7 & $\begin{array}{l}\text { The supervisor evaluates the work of the bank's internal audit function, and determines } \\
\text { whether, and to what extent, it may rely on the internal auditors' work to identify areas of } \\
\text { potential risk. }\end{array}$ \\
\hline
\end{tabular}




\begin{tabular}{|c|c|}
\hline $\begin{array}{l}\text { Description and } \\
\text { findings re EC7 }\end{array}$ & $\begin{array}{l}\text { The NBB deploys on and off-site processes to assess the work of the internal audit function } \\
\text { of the supervised institutions. The prudential expectations regarding internal audit are } \\
\text { based on Article } 20 \text { of the Banking Law and expanded upon in Circular D1 } 97 / 4 \text { of } 30 \text { June } \\
\text { 1997. } \\
\text { Ultimately the assessment of the internal audit function is drawn together during the } \\
\text { annual scorecarding analysis but this will draw on the work of the on and off-site teams. } \\
\text { The off-site function analyzes a number of inputs including: } \\
\text { - The governance memorandum, which is expected to contain the audit charter and } \\
\text { specify the location and reporting lines of internal audit within the organization of } \\
\text { - The bank. } \\
\text { - The management report on internal controls. } \\
\text { - The AML/CFT and compliance reports. } \\
\text { Assessment of the internal audit function is a recurrent item for on-site examination, which } \\
\text { will pay attention, among other aspects, to whether the internal audit has sufficient } \\
\text { standing and authority within the bank. For the systemic firms, contact with the audit } \\
\text { committee is an important and regular component of supervisory contact. }\end{array}$ \\
\hline EC8 & $\begin{array}{l}\text { The supervisor communicates to the bank the findings of its on- and off-site supervisory } \\
\text { analyses by means of written reports or through discussions or meetings with } \\
\text { management. }\end{array}$ \\
\hline & $\begin{array}{l}\text { The findings of the off-site supervisory process is communicated to the management of the } \\
\text { bank through correspondence or meetings with the relevant level of management. For the } \\
\text { systemic firms there is a regular program of contact that includes, inter alia, quarterly } \\
\text { meetings with the chief risk officer. The NBB does not make a practice of sending an annual } \\
\text { letter setting out the planned supervisory program for the year, but will share the output of } \\
\text { the joint risk assessment of a firm/group with the entity in question (following the EU } \\
\text { system of joint assessment and capital decisions). This is not an automatic process under } \\
\text { the EU requirements but the NBB places value on transparency with the institution. } \\
\text { An on-site examination is followed by a report, which will include recommendations but an } \\
\text { information visit is followed by a letter in which recommendations for action may not be } \\
\text { necessary. The assessors reviewed samples of letters and reports (with recommendations) } \\
\text { sent to firms following on-site examinations. } \\
\text { At the end of n onon-site examination, as noted above, an informal debriefing of the } \\
\text { findings takes place with the management, followed by a draft written report to the } \\
\text { management. The management can comment on the report, recommendations and } \\
\text { conclusions. The inspection team will incorporate the management's reactions in finalizing } \\
\text { its report. } \\
\text { The inspection team will also evaluate the management's proposed action plan which must } \\
\text { be submitted to the NBB within one month of having received the final report of the NBB. } \\
\text { A formal response to the action plan is then sent to the management and there is } \\
\text { continuous monitoring of progress of corrective actions against the plan by the NBB until } \\
\text { the recommendations have been concluded to the satisfaction of the supervisory team in } \\
\text { consultation with the inspection team. }\end{array}$ \\
\hline
\end{tabular}




\begin{tabular}{|c|c|}
\hline $\begin{array}{l}\text { Additional } \\
\text { criteria }\end{array}$ & \\
\hline AC1 & $\begin{array}{l}\text { The supervisor meets periodically with senior management and the Board to discuss the } \\
\text { results of supervisory examinations and the external audit. The supervisor should also meet } \\
\text { separately with the independent Board members, as necessary. }\end{array}$ \\
\hline $\begin{array}{l}\text { Description and } \\
\text { findings re } A C 1\end{array}$ & $\begin{array}{l}\text { The NBB indicated that it will meet separately with independent Board members, in some } \\
\text { institutions, depending on the level and nature of the risks concerned, in particular when } \\
\text { issues have already emerged or where high risks have been identified. This is an important } \\
\text { power for the NBB to have but it falls short of being a systematic practice at this time. }\end{array}$ \\
\hline $\begin{array}{l}\text { Assessment of } \\
\text { Principle } 20\end{array}$ & Largely Compliant \\
\hline Comments & 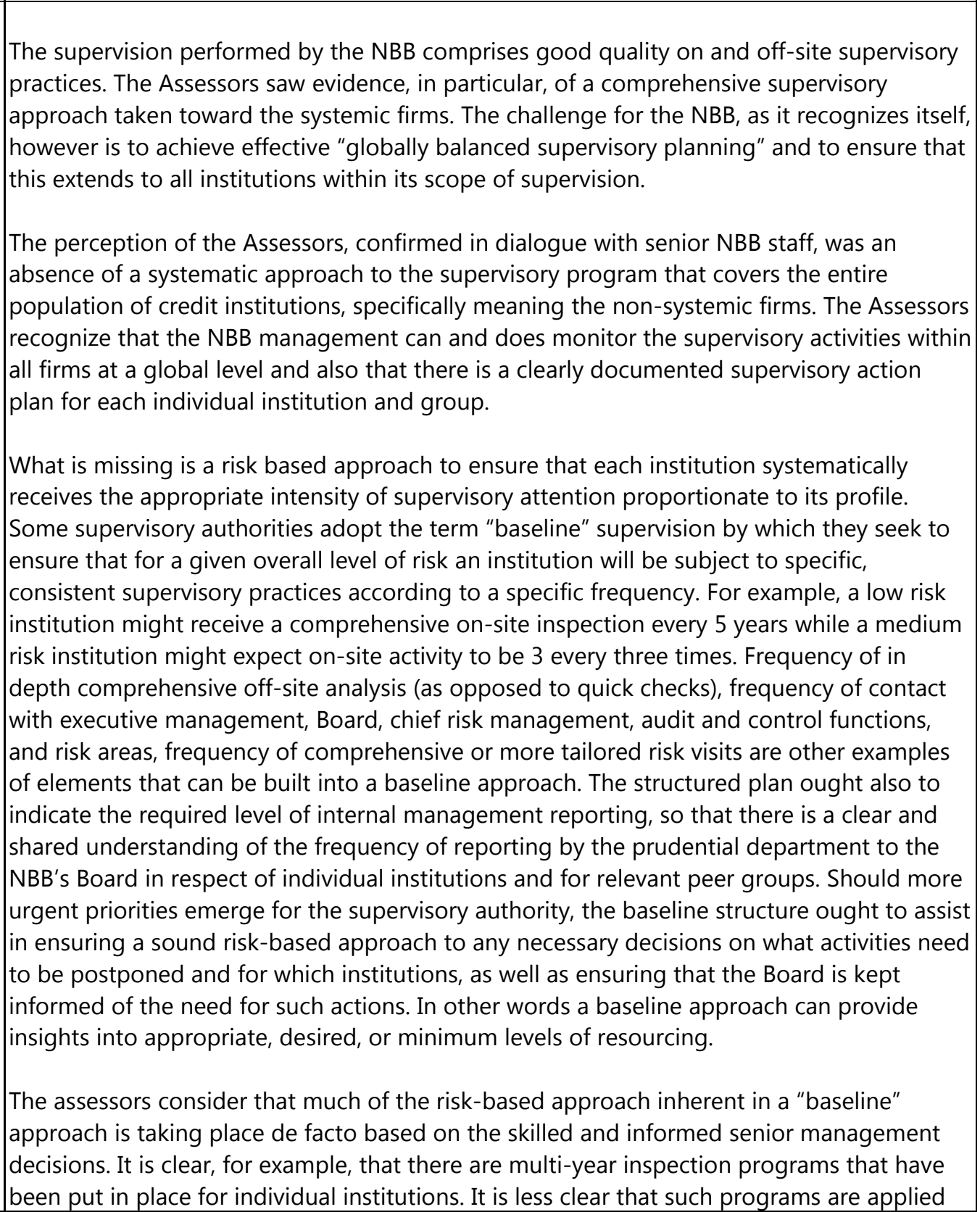 \\
\hline
\end{tabular}




\begin{tabular}{|c|c|}
\hline & $\begin{array}{l}\text { consistently to all similar institutions. There is a lack of documentation and full overview to } \\
\text { monitor and ensure that two similar institutions are indeed receiving appropriately similar } \\
\text { supervisory attention. } \\
\text { Importantly, the NBB is in the course of developing new tools that will be critical to } \\
\text { achieving this greater structural consistency in supervisory processes, namely its work on } \\
\text { "clustering" and on "proportionality." The first project is designed to improve the peer } \\
\text { group clustering on a more refined and risk-focused basis. The "proportionality" project is } \\
\text { intended to permit adjustments to the profile of institutions in the scorecarding application } \\
\text { on the basis of their impact/risk classification and is thus linked with the clustering project. } \\
\text { The successful outcome of these projects, coupled with a "baseline" analysis of supervisory } \\
\text { needs should position the NBB strongly to deliver a stable, systematic and risk- } \\
\text { sophisticated approach to supervision. } \\
\text { It is also noted that the supervisory tools supporting data and analysis of the insurance } \\
\text { companies are also being upgraded as a separate part of the overall PRIME program. } \\
\text { Opportunity should be taken, as is intended, to enhance the depth and integration of risk } \\
\text { assessment of the insurance interests within banking and conglomerate groups. }\end{array}$ \\
\hline Principle 21 & $\begin{array}{l}\text { Supervisory reporting. Supervisors must have a means of collecting, reviewing and } \\
\text { analyzing prudential reports and statistical returns from banks on both a solo and a } \\
\text { consolidated basis, and a means of independent verification of these reports, through } \\
\text { either on-site examinations or use of external experts. }\end{array}$ \\
\hline \multicolumn{2}{|l|}{ Essential criteria } \\
\hline EC1 & $\begin{array}{l}\text { The supervisor has the power to require banks to submit information, on both a solo and a } \\
\text { consolidated basis, on their financial condition, performance, and risks, at regular intervals. } \\
\text { These reports provide information on such matters as on- and off-balance sheet assets and } \\
\text { liabilities, profit and loss, capital adequacy, liquidity, large exposures, asset concentrations } \\
\text { (including by economic sector, geography and currency), asset quality, loan loss } \\
\text { provisioning, related party transactions, interest rate risk and market risk. }\end{array}$ \\
\hline $\begin{array}{l}\text { Description and } \\
\text { findings re } E C 1\end{array}$ & $\begin{array}{l}\text { On the basis of the Article } 44 \text { of the Belgian Law on the supervision of credit institutions ( } 22 \\
\text { March of 1993), the NBB has power to request information on a regular basis from banks. } \\
\text { Banks are required to report both prudential returns, which are submitted on a quarterly } \\
\text { basis and financial accounts, which are submitted quarterly at consolidated level, and } \\
\text { monthly at solo level. } \\
\text { The consolidated prudential reporting framework is aligned with the reporting regime } \\
\text { referred to as Finrep (Financial reporting). This framework is based on the guideline } \\
\text { published by the Committee of European Banking Supervisors in 2005. To assess capital } \\
\text { adequacy both on a solo and a consolidated basis, the NBB has imposed COREP (Common } \\
\text { reporting). This framework is based on the guidelines published by the Committee of } \\
\text { European Banking Supervisors in } 2006 \text {. } \\
\text { The Corep and Finrep framework is in line with Basel II and Basel 2.5. It includes } \\
\text { information on the composition of own funds, the capital requirements, the credit risk } \\
\text { under SA approach or IRB approach, market risk, currency risk, settlement risk, operational } \\
\text { risk and on large exposures. For Pillar } 2 \text { requirements, NBB has also imposed a liquidity } \\
\text { reporting (liquidity of assets, cash in and cash out) and a concentration report covering }\end{array}$ \\
\hline
\end{tabular}




\begin{tabular}{|c|c|}
\hline & $\begin{array}{l}\text { data by economic sector and by geography. An interest rate risk report, based on different } \\
\text { assumptions on changes of the yield curve, is also required. } \\
\text { To assess the financial position of institutions on a solo basis, the NBB has imposed since } \\
1994 \text { its own reporting (Schema A). This reporting includes information regarding on and } \\
\text { off balance sheets assets and liabilities, profit and loss, asset quality, loan loss provisioning, } \\
\text { related party transactions. This framework is based on Belgian GAAP. On a solo basis, banks } \\
\text { have to report their annual accounts using a mandatory chart, which is completed with } \\
\text { additional information when reported to the supervisor. } \\
\text { At a consolidated level, banks have to prepare their annual accounts on the basis of IFRS } \\
\text { and there is no mandatory chart of accounts. However, for prudential purposes, the NBB } \\
\text { requires reporting of the consolidated entity using the European FINREP standardized } \\
\text { format. }\end{array}$ \\
\hline EC2 & $\begin{array}{l}\text { The supervisor provides report instructions that clearly describe the accounting standards } \\
\text { to be used in preparing supervisory reports. Such standards are based on accounting } \\
\text { principles and rules that are widely accepted internationally. }\end{array}$ \\
\hline $\begin{array}{l}\text { Description and } \\
\text { findings re } E C 2\end{array}$ & $\begin{array}{l}\text { The NBB has developed detailed instructions for each of these reporting requirements and } \\
\text { the instructions are publically available on the website of the NBB. For Finrep (consolidated } \\
\text { reporting), banks use IFRS. Belgian GAAP is applied for solo reporting. For Corep, either } \\
\text { IFRS or BEGAAP is used as starting point for calculations. Instructions are also based on } \\
\text { Basel regulation. } \\
\text { The availability of different accounting methodologies does add a dimension of complexity } \\
\text { to performing offsite analysis to understand different accounting treatments, specifically in } \\
\text { the area of valuations. }\end{array}$ \\
\hline EC3 & $\begin{array}{l}\text { The supervisor requires banks to utilize valuation rules that are consistent, realistic and } \\
\text { prudent, taking account of current values where relevant. }\end{array}$ \\
\hline $\begin{array}{l}\text { Description and } \\
\text { findings re EC3 }\end{array}$ & $\begin{array}{l}\text { Consolidated reporting in Finrep uses IFRS for valuation of assets. For reporting on a solo } \\
\text { basis in Schema A, BGAAP is used and a rule of prudence is included. } \\
\text { Under BGAAP, the use of market value is more limited. Derivatives other that those } \\
\text { qualifying as hedging are measured at market value and differences between capital gains } \\
\text { and losses are accounted for in profit and loss when there is an active market. If there is no } \\
\text { active market only capital losses are recorded in profit and loss. For derivatives qualifying } \\
\text { as hedge accounting, gains and loss are recorded in profit and loss on a pro rata temporis. } \\
\text { Investment portfolios are at LOCOM (Lower of cost or market) instead of at fair value } \\
\text { through equity as in IFRSs. } \\
\text { BGAAP entails some degree of questioning whether the valuation rules are consistent, } \\
\text { realistic and prudent and takes into account current values. Specifically, investment } \\
\text { portfolios are valued on the basis of the LOCOM methodology, which is the lower of cost } \\
\text { or market value. The impact of different accounting treatments between banks within the } \\
\text { same group could potentially result in different capital and performance outcomes. The } \\
\text { availability of different accounting methodologies for valuations does not meet this } \\
\text { criterion. }\end{array}$ \\
\hline
\end{tabular}




\begin{tabular}{|c|c|}
\hline EC4 & $\begin{array}{l}\text { The supervisor collects and analyses information from banks at a frequency (e.g., monthly, } \\
\text { quarterly and annually) commensurate with the nature of the information requested, and } \\
\text { the size, activities and risk profile of the individual bank. }\end{array}$ \\
\hline $\begin{array}{l}\text { Description and } \\
\text { findings re EC4 }\end{array}$ & $\begin{array}{l}\text { The frequency for all credit institutions to submit data is consistent across the sector } \\
\text { regardless of size, activities and risk profile. For financial information, capital adequacy and } \\
\text { interest rate risk, the frequency is quarterly for the large majority of items. For liquidity, the } \\
\text { frequency is monthly and for concentration it is annually. For public, information it is only } \\
\text { mandatory on a annual basis for solo accounts based on a mandatory chart of accounts. } \\
\text { The frequency for data associated with concentration risk is annual. This is one area of the } \\
\text { data collection, which does not align with the same quarterly frequency of other material } \\
\text { prudential data. }\end{array}$ \\
\hline EC5 & $\begin{array}{l}\text { In order to make meaningful comparisons between banks and banking groups, the } \\
\text { supervisor collects data from all banks and all relevant entities covered by consolidated } \\
\text { supervision on a comparable basis and related to the same dates (stock data) and periods } \\
\text { (flow data). }\end{array}$ \\
\hline $\begin{array}{l}\text { Description and } \\
\text { findings re EC5 }\end{array}$ & $\begin{array}{l}\text { Regarding supervisory reporting, the scope and the periodicity are the same for all banks. } \\
\text { For public information, the publication of general purpose financial statement is mandatory } \\
\text { on an annual basis. The reporting requirements of the NBB enable a satisfactory degree of } \\
\text { transparency across banks. } \\
\text { The Corep, the Finrep and the liquidity reporting are collected for holding companies. }\end{array}$ \\
\hline EC6 & $\begin{array}{l}\text { The supervisor has the power to request and receive any relevant information from banks, } \\
\text { as well as any of their related companies, irrespective of their activities, where the } \\
\text { supervisor believes that it is material to the financial situation of the bank or banking } \\
\text { group, or to the assessment of the risks of the bank or banking group. This includes } \\
\text { internal management information. }\end{array}$ \\
\hline $\begin{array}{l}\text { Description and } \\
\text { findings re EC6 }\end{array}$ & $\begin{array}{l}\text { Article } 44 \text { of the Belgian Law gives the NBB the power to request and receive any relevant } \\
\text { information, including internal management information. Examples were provided to } \\
\text { evidence that the NBB use this power to receive reporting on a higher frequency in } \\
\text { exceptional cases. For example, the NBB has mandated daily liquidity reporting for larger } \\
\text { systemic banks since the crisis. }\end{array}$ \\
\hline EC7 & $\begin{array}{l}\text { The supervisor has the power of full access to all bank records for the furtherance of } \\
\text { supervisory work. The supervisor also has similar access to the bank's Board, management } \\
\text { and staff, when required. }\end{array}$ \\
\hline $\begin{array}{l}\text { Description and } \\
\text { findings re EC7 }\end{array}$ & $\begin{array}{l}\text { On the basis of article } 46 \text { of the Belgian law on the supervision of credit institutions, the } \\
\text { NBB has access to all bank records to fulfill its tasks by way of on-site inspection or off-site } \\
\text { inspection. }\end{array}$ \\
\hline EC8 & $\begin{array}{l}\text { The supervisor has a means of enforcing compliance with the requirement that the } \\
\text { information be submitted on a timely and accurate basis. The supervisor determines that } \\
\text { the appropriate level of senior management is responsible for the accuracy of supervisory } \\
\text { returns, can impose penalties for misreporting and persistent errors, and can require that } \\
\text { inaccurate information be amended. }\end{array}$ \\
\hline
\end{tabular}




\begin{tabular}{|c|c|}
\hline $\begin{array}{l}\text { Description and } \\
\text { findings re EC8 }\end{array}$ & $\begin{array}{l}\text { On the basis of the article } 103 \text { of the Belgian law on the supervision of credit institutions } \\
\text { ( } 22 \text { March of 1993), the supervisor has the power to enforce compliance with the } \\
\text { requirement that information be submitted on a timely and accurate basis. On basis of this } \\
\text { article, the supervisor can impose penalties with a maximum of } 2.500 .000 \text { millions of Euros } \\
\text { or } 50.000 \text { Euros by day of delay if the information is not corrected. } \\
\text { Article } 44 \text { states that the "effective management of the credit institution must declare to } \\
\text { the Bank (NBB) that the periodic reports sent to it by the institution at the end of the first } \\
\text { six months and at the end of its financial year, accurately reflect the accounts and } \\
\text { inventories." In this statement, the Board is held responsible for the accuracy of the } \\
\text { financial accounts. }\end{array}$ \\
\hline EC9 & $\begin{array}{l}\text { The supervisor utilizes policies and processes to confirm the validity and integrity of } \\
\text { supervisory information. This includes a programme for the periodic verification of } \\
\text { supervisory returns by means either of the supervisor's own staff or of external experts. }\end{array}$ \\
\hline $\begin{array}{l}\text { Description and } \\
\text { findings re EC9 }\end{array}$ & $\begin{array}{l}\text { For all templates included in the reporting, the NBB has defined a set of validation rules. If } \\
\text { these validation rules are not respected, an automatic message of error is sent to the } \\
\text { banks. NBB financial analysts regularly review the quality of the data submitted to the NBB. } \\
\text { Examples of team meetings where the outcome from offsite analysis is discussed and } \\
\text { outcomes agreed. The analysis looked to be of high quality. } \\
\text { For the reporting transmitted at year-end and half year-end, the bank's external auditor has } \\
\text { to inform the NBB on the results on his/her audit of the reporting (full for the annuals and } \\
\text { limited review for half yearly).. In addition, he/she has to confirm that the reporting } \\
\text { contains all data from the accounting records and other inventories and that the same } \\
\text { measurement criteria as used for the annual accounts have been applied. }\end{array}$ \\
\hline EC10 & $\begin{array}{l}\text { The supervisor clearly defines and documents the roles and responsibilities of external } \\
\text { experts, including the scope of the work, when they are appointed to conduct supervisory } \\
\text { tasks and monitors the quality of the work. External experts may be utilized for routine } \\
\text { validation or to examine specific aspects of banks' operations. }\end{array}$ \\
\hline $\begin{array}{l}\text { Description and } \\
\text { findings re EC10 }\end{array}$ & $\begin{array}{l}\text { Article 55, section 1, paragraph } 2 \text { of the Belgian law on the supervision of credit institutions } \\
\text { (22 March of 1993) defines the role of the banks' external auditors. } \\
\text { For the reporting transmitted at year-end and half year-end the bank's external auditor has } \\
\text { to inform the NBB on the results on his/her audit of the reporting. In addition, he/she has } \\
\text { to confirm that the reporting contains all data from the accounting records and other } \\
\text { inventories and that the same measurement criteria as used for the annual accounts have } \\
\text { been applied. A principle of materiality applies. }\end{array}$ \\
\hline EC11 & $\begin{array}{l}\text { The supervisor requires that external experts bring to its attention promptly any material } \\
\text { shortcomings identified during the course of any work undertaken by them for supervisory } \\
\text { purposes. }\end{array}$ \\
\hline $\begin{array}{l}\text { Description and } \\
\text { findings re } E C 11\end{array}$ & $\begin{array}{l}\text { The Banking Law states that the bank's external auditor should inform the NBB as soon as } \\
\text { he/she becomes aware of } \\
\text { decisions, facts or developments that may influence significantly the bank's } \\
\text { financial position or its administrative/accounting system or its internal control; }\end{array}$ \\
\hline
\end{tabular}




\begin{tabular}{|c|c|}
\hline & $\begin{array}{l}\text { decisions or facts that may indicate that the bank has infringed company law, the } \\
\text { bank's bylaws, the banking act and its related decisions and regulations; } \\
\text { other decisions of facts that could lead to a refusal to certify the annual accounts. } \\
\text { A Circular letter of the NBB explaining these legal obligations has been published (it } \\
\text { contains a list of examples of decisions/facts/developments that may be of interest to the } \\
\text { NBB). }\end{array}$ \\
\hline $\begin{array}{l}\text { Assessment of } \\
\text { Principle } 21\end{array}$ & Compliant \\
\hline Comments & $\begin{array}{l}\text { The availability of different approaches to accounting methodologies does raise } \\
\text { the question of consistency. Largely regards a solo vs consolidated requirements } \\
\text { and whether the NBB has regulatory requirements that are consistent. } \\
\text { Reporting dates for major balance sheet and risk items not aligned. For instance, } \\
\text { there is monthly solo financial and prudential returns submitted } 11 \text { (to 25) days } \\
\text { after end of period, however for the reporting lag for IRRBB and FINREP, COREP } \\
\text { consolidated, concentration risk is } 2.5 \text { months. Lack of consistency in reports of } \\
\text { data doesn't support comprehensive and timely analysis of prudential data where } \\
\text { supervisors often become more attuned to management information. This should } \\
\text { be addressed in the PRIME project. }\end{array}$ \\
\hline Principle 22 & $\begin{array}{l}\text { Accounting and disclosure. Supervisors must be satisfied that each bank maintains } \\
\text { adequate records drawn up in accordance with accounting policies and practices that are } \\
\text { widely accepted internationally, and publishes, on a regular basis, information that fairly } \\
\text { reflects its financial condition and profitability. }\end{array}$ \\
\hline \multicolumn{2}{|l|}{ Essential criteria } \\
\hline EC1 & $\begin{array}{l}\text { The supervisor has the power to hold bank management and the bank's Board responsible } \\
\text { for ensuring that financial record-keeping systems and the data they produce are reliable. }\end{array}$ \\
\hline $\begin{array}{l}\text { Description and } \\
\text { findings re EC1 }\end{array}$ & $\begin{array}{l}\text { Banking Law explicitly gives this power derived from three separate Articles of the Banking } \\
\text { Law } 1993 \text {. Firstly, Article } 20, \S 1 \text { of the Banking Law states that a bank should notably have: } \\
\text { (i) an appropriate administrative and accounting system; and, (ii) an appropriate internal } \\
\text { control system. Secondly, pursuant to the } \$ 32 \text { of the same article, banks must have in place } \\
\text { an appropriate internal control system that provides reasonable assurance that the process } \\
\text { for financial reporting is reliable and that the accounts are drawn up in accordance with the } \\
\text { applicable regulation. } \\
\text { In accordance with article } 44 \text {, paragraph } 2 \text {, senior management must explicitly confirm that } \\
\text { the returns reported to the NBB conform with the accounts and the inventories. } \\
\text { Additionally, management must explicitly confirm that the information reported to the NBB } \\
\text { conforms with the instructions given by the NBB. The references however do not mention } \\
\text { specifically the responsibility of the board. }\end{array}$ \\
\hline EC2 & $\begin{array}{l}\text { The supervisor has the power to hold bank management and the bank's Board responsible } \\
\text { for ensuring that the financial statements issued annually to the public receive proper } \\
\text { external verification and bear an external auditor's opinion. }\end{array}$ \\
\hline $\begin{array}{l}\text { Description and } \\
\text { findings re EC2 }\end{array}$ & $\begin{array}{l}\text { Article } 55 \text { of the Banking Law requires that annual and semi-annual prudential returns are } \\
\text { verified by the external auditors. The verification consists in a full audit of the annual }\end{array}$ \\
\hline
\end{tabular}




\begin{tabular}{|c|c|}
\hline & $\begin{array}{l}\text { reporting and in a limited review of semi-annual reporting. } \\
\text { The verification is provided by the external auditor required by the Banking Law and the } \\
\text { external auditor is licensed as a professional auditor and must also obtain a preliminary } \\
\text { authorisation from the NBB - only auditors having this authorization may audit the financial } \\
\text { statements of a bank (article } 50 \text { of the banking act). } \\
\text { All credit institutions incorporated under Belgian Law must make available a yearly Pillar } 3 \\
\text { report in accordance with the Title XIV of the regulation of the NBB dated } 06.12 .2011 \\
\text { implementing the CRD. } \\
\text { Explicit reference in the Banking Law for the responsibility of the Board is less clear. }\end{array}$ \\
\hline EC3 & $\begin{array}{l}\text { The supervisor requires banks to utilize valuation rules that are consistent, realistic and } \\
\text { prudent, taking account of current values where relevant, and to show profits net of } \\
\text { appropriate provisions. }\end{array}$ \\
\hline & $\begin{array}{l}\text { The Royal Decree of } 23.09 .1992 \text { on annual accounts of banks sets out the Belgian } \\
\text { accounting rules (BGAAP), including measurement rules, for banks. The governance of } \\
\text { accounting rules is articulated in Article } 44 \text { of the Banking Act). The principle of consistency, } \\
\text { realism and prudence are covered by this Royal Decree in Articles } 15 \text { to } 19 . \\
\text { The accounting rules for solo are based upon BGAAP and for consolidated IFRS. The } \\
\text { valuation principles applicable at the consolidated level are those set out in IFRS. Given that } \\
\text { two accounting approaches are applicable it is hard to see how the goal of consistency is } \\
\text { achieved. For example, on a consolidated basis, securities are allocated to the following } \\
\text { portfolios: trading, loans and receivables, available for sale and held to maturity. On a solo } \\
\text { basis, a trading portfolio at market value through profit and loss and an investment } \\
\text { portfolio at LOCOM. Securities are classified in the investment portfolio if they are held to } \\
\text { obtain a return in long term. } \\
\text { The NBB has performed work to determine the main differences between IFRS and BGAAP. } \\
\text { The latest review of differences between IFRS and Belgian GAAP has been made in } \\
\text { connection with the work done within EBA on the definition of implementing measure for } \\
\text { leverage ratios. Earlier, in March } 2008, \text { the CBFA contributed to a workshop organized with } \\
\text { external experts on the feasibility of the application of IFRS to solo accounts. A number of } \\
\text { differences between IFRS and BGAAP were analyzed at that occasion. } \\
\text { In practice, the NBB has observed a divergence between banks in valuation of traded } \\
\text { products, some using a mark-to-market approach and others using a mark-to-model. The } \\
\text { example of one bank was given, which says less about the differences between IFRS and } \\
\text { BGAAP and more about the need for clear regulatory guidance regarding appropriate } \\
\text { valuation methodologies. This principle could be extended to the banking book also. } \\
\text { The assessors would question whether it is easy to continuously understand the differences } \\
\text { between the accounting methodologies of IRFS and BGAAP to make sense of the } \\
\text { differences in quarterly reporting within a consolidated group. }\end{array}$ \\
\hline EC4 & $\begin{array}{l}\text { Laws or regulations set, or the supervisor has the power, in appropriate circumstances, to } \\
\text { establish, the scope of external audits of individual banks and the standards to be followed } \\
\text { in performing such audits. }\end{array}$ \\
\hline $\begin{array}{l}\text { Description and } \\
\text { findings re EC4 }\end{array}$ & $\begin{array}{l}\text { Pursuant to article } 55 \text {, the NBB can define further the scope of external audits of individual } \\
\text { banks in specific circumstances, for supervisory purposes. The NBB has the powers to } \\
\text { require a special purpose audit - see article } 55 \text {, section } 1,3^{\circ} \text {. Costs have to be borne by the }\end{array}$ \\
\hline
\end{tabular}




\begin{tabular}{|c|c|}
\hline & $\begin{array}{l}\text { bank. The NBB has the powers to require a special purpose audit - see article } 55 \text {, section } 1 \text {, } \\
3^{\circ} \text {. Costs have to be borne by the bank. The NBB was able to point to recent examples } \\
\text { where they have exercised this power. }\end{array}$ \\
\hline EC5 & $\begin{array}{l}\text { Supervisory guidelines or local auditing standards determine that audits cover such areas } \\
\text { as the loan portfolio, loan loss reserves, non-performing assets, asset valuations, trading } \\
\text { and other securities activities, derivatives, asset securitisations, and the adequacy of internal } \\
\text { controls over financial reporting. }\end{array}$ \\
\hline $\begin{array}{l}\text { Description and } \\
\text { findings re EC5 }\end{array}$ & $\begin{array}{l}\text { All credit institutions incorporated under Belgian Law must make available a yearly Pillar } 3 \\
\text { report in accordance with the Title XIV of the regulation of the NBB dated 06.12.2011 } \\
\text { implementing the CRD. In this context (accounting rules and implemented CRD), } \\
\text { quantitative and qualitative information related to related party transactions, risk } \\
\text { exposures, restructured loans, provisioning, and risk management practices must be } \\
\text { disclosed. }\end{array}$ \\
\hline EC6 & $\begin{array}{l}\text { The supervisor has the power to reject and rescind the appointment of an external auditor } \\
\text { that is deemed to have inadequate expertise or independence, or not to be subject to or } \\
\text { not to follow established professional standards. }\end{array}$ \\
\hline $\begin{array}{l}\text { Description and } \\
\text { findings re EC6 }\end{array}$ & $\begin{array}{l}\text { NBB approves the external auditor and in the future after a fixed term expires the external } \\
\text { auditor will need to be rotated. According to article } 53 \text { of the banking act, the appointment } \\
\text { of a bank's external auditor has to be approved by the NBB. The NBB can review letters of } \\
\text { engagements and audit contracts. }\end{array}$ \\
\hline EC7 & $\begin{array}{l}\text { The supervisor requires banks to produce annual audited financial statements based on } \\
\text { accounting principles and rules that are widely accepted internationally and have been } \\
\text { audited in accordance with internationally accepted auditing practices and standards. }\end{array}$ \\
\hline & $\begin{array}{l}\text { Article } 44 \text { of the Banking Law, BGAAP accounting rules applicable to banks at solo level } \\
\text { must be defined by Royal Decree that can be adopted after consultation of the NBB. On } \\
\text { the basis of article } 38 \text { of the } 1992 \text { Royal Decree, the NBB has the power to give waivers to } \\
\text { the application of these accounting rules. In addition, the NBB can provide guidelines on } \\
\text { the accounting principles to be followed for the preparation and presentation of the solo } \\
\text { prudential reporting (Schema A). } \\
\text { Financial statement prepared on a consolidated basis are based on IFRS as issued by the } \\
\text { IASB and endorsed for application in the EU pursuant to the Regulation EC } 1606 / 2002 \text { on } \\
\text { the application of international accounting standards. } \\
\text { There is no plan to apply IFRS on a solo basis and there is no quantitative evaluation of } \\
\text { differences between Belgian GAAP and IFRS. }\end{array}$ \\
\hline EC8 & $\begin{array}{l}\text { Laws, regulations or the supervisor require periodic public disclosures of information by } \\
\text { banks that adequately reflect the bank's true financial condition. The requirements imposed } \\
\text { should promote the comparability, relevance, reliability and timeliness of the information } \\
\text { disclosed. }\end{array}$ \\
\hline $\begin{array}{l}\text { Description and } \\
\text { findings re EC8 }\end{array}$ & $\begin{array}{l}\text { Banks are required to publish complete information in a timely and regular basis regarding } \\
\text { their activities, financial position and performance. These disclosure requirements were } \\
\text { adopted pursuant to EU Directives on company law and annual accounts. The requirements } \\
\text { are basically set out in the Company Law Code (article } 92 \text { to 129) and in two specific } \\
\text { accounting regulations applicable to bank. } \\
\text { All credit institutions incorporated under Belgian Law must make available a yearly Pillar } 3\end{array}$ \\
\hline
\end{tabular}




\begin{tabular}{|c|c|}
\hline & $\begin{array}{l}\text { report in accordance with the Title XIV of the regulation of the NBB dated } 06.12 .2011 \\
\text { implementing the CRD. In this context (accounting rules and implemented CRD), } \\
\text { quantitative and qualitative information related to related party transactions, risk } \\
\text { exposures, restructured loans, provisioning, and risk management practices must be } \\
\text { disclosed. } \\
\text { The NBB is currently preparing a horizontal assessment of the Pillar } 3 \text { reports of some } \\
\text { major Belgian credit institutions. }\end{array}$ \\
\hline EC9 & $\begin{array}{l}\text { The required disclosures include both qualitative and quantitative information on a bank's } \\
\text { financial performance, financial position, risk management strategies and practices, risk } \\
\text { exposures, transactions with related parties, accounting policies, and basic business, } \\
\text { management and governance. }\end{array}$ \\
\hline $\begin{array}{l}\text { Description and } \\
\text { findings re EC9 }\end{array}$ & $\begin{array}{l}\text { The requirements on general purpose financial statements and on (Pillar 3) risk report } \\
\text { include both qualitative and quantitative information on a bank's financial performance, } \\
\text { financial position, risk management strategies and practices, risk exposures, transactions } \\
\text { with related parties, accounting policies, and basic business, management and governance. } \\
\text { Banks are required to report quarterly prudential returns and half yearly accounts and a full } \\
\text { set of annual accounts. The Internal Controls Report by management and accompanied } \\
\text { with a report from the external auditor will comment on governance. }\end{array}$ \\
\hline EC10 & $\begin{array}{l}\text { Laws, regulations or the supervisor provide effective review and enforcement mechanisms } \\
\text { designed to confirm compliance with disclosure standards. }\end{array}$ \\
\hline $\begin{array}{l}\text { Description and } \\
\text { findings re EC10 }\end{array}$ & $\begin{array}{l}\text { Banks are required to publish Pillar } 3 \text { reports annually available to the public to enhance } \\
\text { market discipline. The reports are included in the supervisory process. Management reports } \\
\text { and published accounts are used by the supervisor as an input into the risk scorecarding } \\
\text { process. }\end{array}$ \\
\hline EC11 & $\begin{array}{l}\text { The supervisor or other relevant bodies publish aggregate information on the banking } \\
\text { system to facilitate public understanding of the banking system and the exercise of market } \\
\text { discipline. Such information includes aggregate data on balance sheet indicators and } \\
\text { statistical parameters that reflect the principal aspects of banks' operations (balance sheet } \\
\text { structure, capital ratios, income earning capacity, and risk profiles). }\end{array}$ \\
\hline $\begin{array}{l}\text { Description and } \\
\text { findings re EC11 }\end{array}$ & The NBB publishes an annual financial stability report that can be located on the website. \\
\hline \multicolumn{2}{|l|}{$\begin{array}{l}\text { Additional } \\
\text { criteria }\end{array}$} \\
\hline AC1 & $\begin{array}{l}\text { The supervisor meets periodically with external audit firms to discuss issues of common } \\
\text { interest relating to bank operations. }\end{array}$ \\
\hline $\begin{array}{l}\text { Description and } \\
\text { findings re } A C 1\end{array}$ & $\begin{array}{l}\text { It was evident that the NBB's supervision plan included frequent meetings with the external } \\
\text { auditor given the auditors role as collaborator in the supervision framework. } \\
\text { The NBB has the right to meet the external auditors without the approval of the bank. } \\
\text { According to the banking act, the external auditor is seen as a collaborator of the NBB (see } \\
\text { article 55, section } 1 \text { of the banking act). }\end{array}$ \\
\hline AC2 & $\begin{array}{l}\text { External auditors, whether or not utilised by the supervisor for supervisory purposes, have } \\
\text { the duty to report to the supervisor matters of material significance, for example failure to } \\
\text { comply with the licensing criteria or breaches of banking or other laws, or other matters, }\end{array}$ \\
\hline
\end{tabular}




\begin{tabular}{|c|c|}
\hline & $\begin{array}{l}\text { which they believe are likely to be of material significance to the functions of the } \\
\text { supervisor. Laws or regulations ensure that auditors who make any such reports in good } \\
\text { faith cannot be held liable for breach of a duty of confidentiality. }\end{array}$ \\
\hline $\begin{array}{l}\text { Description and } \\
\text { findings re AC2 }\end{array}$ & $\begin{array}{l}\text { A safe harbour provision exists (which is compliant with the EC safe harbour provision). See } \\
\text { article } 55 \text {, section } 2 \text { of the banking act. }\end{array}$ \\
\hline AC3 & $\begin{array}{l}\text { Laws, regulations or the supervisor require banks to rotate their external auditors (either } \\
\text { the firm or individuals within the firm) from time to time. }\end{array}$ \\
\hline $\begin{array}{l}\text { Description and } \\
\text { findings re } A C 3\end{array}$ & $\begin{array}{l}\text { The standards of the audit profession requires a rotation of the engagement partner after } \\
\text { six years or in the case of a sole practitioner, to transfer the audit to another external } \\
\text { auditor after six years (standard relating to the independence of external auditors dated } \\
\text { 29.06.2008 - paragraph 6.2). }\end{array}$ \\
\hline AC4 & The supervisor requires banks to have a formal disclosure policy. \\
\hline $\begin{array}{l}\text { Description and } \\
\text { findings re AC4 }\end{array}$ & $\begin{array}{l}\text { According to Article } 20 \text { ter of the banking act the NBB determines the minimum information } \\
\text { that credit institutions must disclose. However, there is no specific requirement for a bank } \\
\text { to have a formal disclosure policy. }\end{array}$ \\
\hline AC5 & The supervisor has the power to access external auditors' working papers, where necessary. \\
\hline $\begin{array}{l}\text { Description and } \\
\text { findings re AC5 }\end{array}$ & $\begin{array}{l}\text { The NBB has no such power. The working papers of an external auditor are confidential and } \\
\text { only the quality control inspectors or an examining magistrate have to power to access the } \\
\text { working papers of the external auditors. }\end{array}$ \\
\hline $\begin{array}{l}\text { Assessment of } \\
\text { Principle } 22 \\
\end{array}$ & Compliant. \\
\hline Comments & $\begin{array}{l}\text { IFRS is applied only at consolidated level and BGAAP at the solo level. Currently there } \\
\text { is no plan to migrate accounting requirements for all banks to IFRS. A comprehensive } \\
\text { review of the differences between BGAAP and IFRS has not been performed, although } \\
\text { some ad hoc work has been completed i.e., most recently in regards to the differences } \\
\text { in the application of the leverage ratio. }\end{array}$ \\
\hline Principle 23 & $\begin{array}{l}\text { Corrective and remedial powers of supervisors. Supervisors must have at their disposal } \\
\text { an adequate range of supervisory tools to bring about timely corrective actions. This } \\
\text { includes the ability, where appropriate, to revoke the banking license or to recommend its } \\
\text { revocation. }\end{array}$ \\
\hline \multicolumn{2}{|l|}{ Essential criteria } \\
\hline EC1 & $\begin{array}{l}\text { The supervisor raises supervisory concerns with management or, where appropriate, the } \\
\text { Board, at an early stage, and requires that these concerns are addressed in a timely } \\
\text { manner. Where the supervisor requires the bank to take significant remedial actions, these } \\
\text { are addressed in a written document to the Board. The supervisor requires the bank to } \\
\text { submit regular written progress reports and checks that remedial actions are completed } \\
\text { satisfactorily. }\end{array}$ \\
\hline $\begin{array}{l}\text { Description and } \\
\text { findings re EC1 }\end{array}$ & $\begin{array}{l}\text { When applying remedial measures (under Article } 57 \text { of the Banking Law - see EC6) the NBB } \\
\text { may either apply a timetable by which the credit institution must comply or, in cases of } \\
\text { extreme urgency may proceed without determining a timescale. } \\
\text { Remedial actions under Article } 57 \text { are communicated formally to the board of directors of }\end{array}$ \\
\hline
\end{tabular}




\begin{tabular}{|c|c|}
\hline & $\begin{array}{l}\text { the credit institution in a written document and requires that progress reports are } \\
\text { submitted to the NBB in writing. The assessors were able to review examples of interactions } \\
\text { between the NBB and credit institutions and follow the file of a recent case that required } \\
\text { the use of Article } 57 \text { powers by the NBB. }\end{array}$ \\
\hline EC2 & $\begin{array}{l}\text { The supervisor participates in deciding when and how to effect the orderly resolution of a } \\
\text { problem bank situation (which could include closure, or assisting in restructuring, or } \\
\text { merger with a stronger institution). }\end{array}$ \\
\hline $\begin{array}{l}\text { Description and } \\
\text { findings re EC2 }\end{array}$ & $\begin{array}{l}\text { Under Article } 57 \text { bis of the Banking Law and when acting in the interests of the stability of } \\
\text { the state or of the international financial system, the King (i.e., the Federal Government) } \\
\text { either on his own initiative or at the recommendation of the NBB can issue a Royal Decree } \\
\text { for the resolution of a credit institution. The Royal Decree is agreed following consultation } \\
\text { with the Council of Ministers. If the initiative for resolution does not come from the NBB, } \\
\text { its opinion must be sought although it is not binding. } \\
\text { The Royal Decree may require the transfer or sale of: } \\
\text { - assets and liabilities, one or more branches of activity, or all or a part of the rights } \\
\quad \text { and obligations of the credit institution in question; } \\
\text { grant voting rights by the credit institution. } \\
\text { The NBB has powers (Article } 57 \text { ) to impose certain reorganization/ recovery measures such } \\
\text { as the designation of a special commissioner and the total or partial suspension or } \\
\text { prohibition of activities if it judges such measures adequate to preserve or re-establish the } \\
\text { financial position of a credit institution. To the extent it affects the rights of third parties in } \\
\text { other Member States the measures taken need to be publicly disclosed (Article } 109 / 1 \text { et } \\
\text { seq.). }\end{array}$ \\
\hline EC3 & $\begin{array}{l}\text { The supervisor has available an appropriate range of supervisory tools for use when, in the } \\
\text { supervisor's judgment, a bank is not complying with laws, regulations or supervisory } \\
\text { decisions, or is engaged in unsafe or unsound practices, or when the interests of depositors } \\
\text { are otherwise threatened. These tools include the ability to require a bank to take prompt } \\
\text { remedial action and to impose penalties. In practice, the range of tools is applied in } \\
\text { accordance with the gravity of a situation. }\end{array}$ \\
\hline EC4 & $\begin{array}{l}\text { The supervisor has available a broad range of possible measures to address such scenarios } \\
\text { as described in EC } 3 \text { above and provides clear prudential objectives or sets out the actions } \\
\text { to be taken, which may include restricting the current activities of the bank, withholding } \\
\text { approval of new activities or acquisitions, restricting or suspending payments to } \\
\text { shareholders or share repurchases, restricting asset transfers, barring individuals from } \\
\text { banking, replacing or restricting the powers of managers, Board directors or controlling } \\
\text { owners, facilitating a takeover by or merger with a healthier institution, providing for the } \\
\text { interim management of the bank, and revoking or recommending the revocation of the } \\
\text { banking license. }\end{array}$ \\
\hline $\begin{array}{l}\text { Description and } \\
\text { findings re EC3 } \\
\text { and EC4 }\end{array}$ & $\begin{array}{l}\text { Remedial and restructuring measures available to the NBB are set out in the Banking Law } \\
\text { (Articles } 57 \text { and } 57 \text { bis). } \\
\text { Under Article } 57 \text { and in response to a situation where the NBB finds that a credit institution } \\
\text { is not operating in accordance with the provisions of this Law and its implementing decrees }\end{array}$ \\
\hline
\end{tabular}




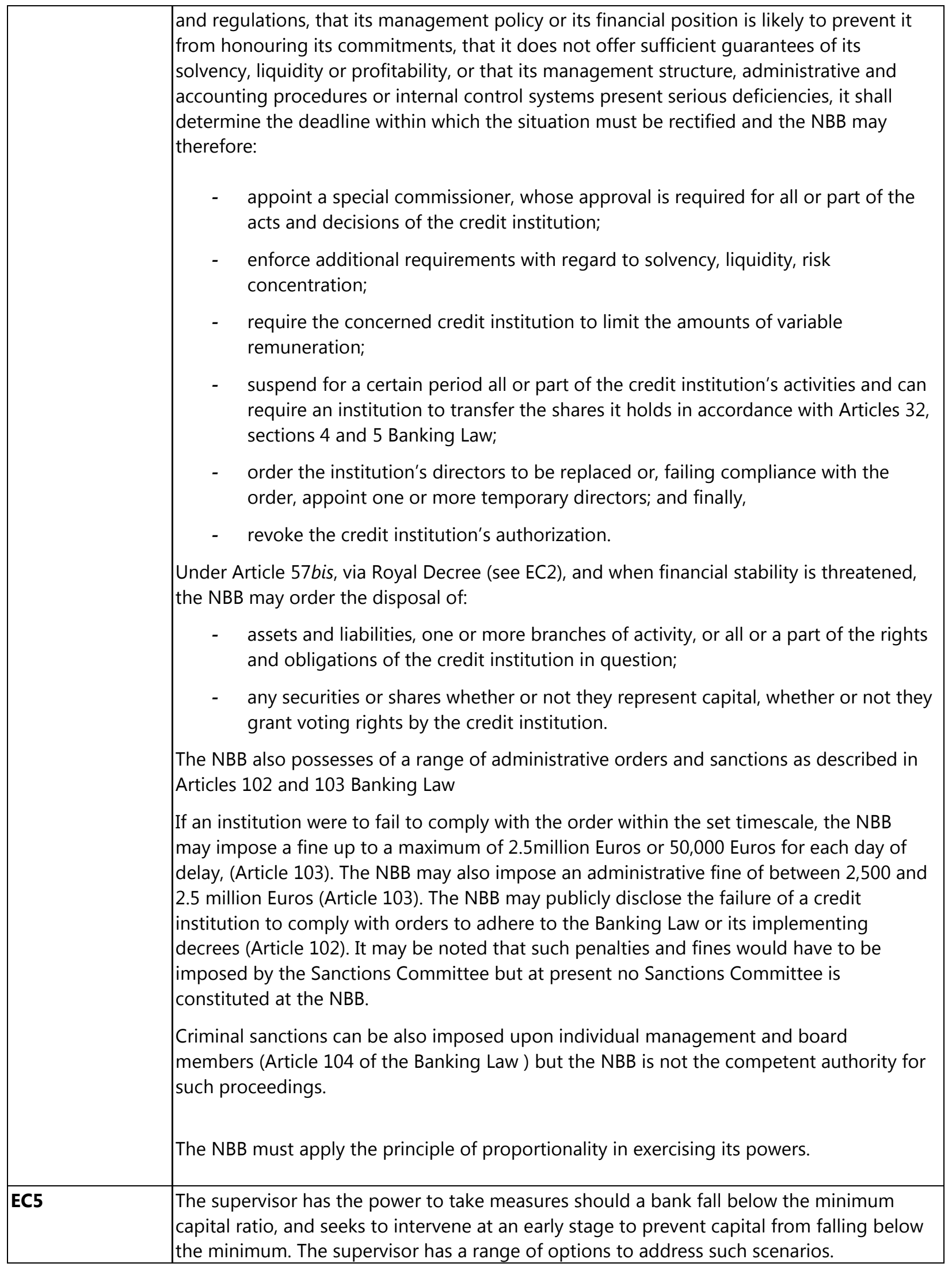




\begin{tabular}{|c|c|}
\hline $\begin{array}{l}\text { Description and } \\
\text { findings re EC5 }\end{array}$ & $\begin{array}{l}\text { The NBB can impose specific solvency requirements upon a credit institution (Article } 43 \text {, } \\
\text { section } 3 \text { of the Banking Law). } \\
\text { If the NBB judges the capital requirements policy of a credit institution inappropriate for its } \\
\text { risk profile, the NBB can - besides the exceptional measures as described in Article } 57 \text { (see } \\
\text { EC6 below) - impose requirements on solvency, liquidity, risk concentration en risk } \\
\text { positions in addition to the criteria and procedures that apply to all credit institutions. }\end{array}$ \\
\hline EC6 & $\begin{array}{l}\text { The supervisor applies penalties and sanctions not only to the bank but, when and if } \\
\text { necessary, also to management and/or the Board, or individuals therein. }\end{array}$ \\
\hline & $\begin{array}{l}\text { Should the NBB find serious deficiencies in an institution (Article 57) it will determine the } \\
\text { timeframe within which the credit institution must rectify the situation (though may act } \\
\text { faster in an emergency). If the situation has not been rectified by the imposed deadline, } \\
\text { the NBB's powers include the ability to: } \\
\text { - } \quad \text { appoint a special commissioner, whose approval is required for all or part of the } \\
\text { acts and decisions of the credit institution (in practice this means that for all acts } \\
\text { and decisions of all organs of the credit institution the written, general or specific } \\
\text { authorization of such commissioner is obligatory. The NBB can limit the kind of } \\
\text { operations for which such a written authorization is required); } \\
\text { order the institution's directors to be replaced or, failing compliance with the } \\
\text { order, appoint one or more temporary directors; and finally, } \\
\text { The NBB must apply principle of proportionality in exercising its powers. } \\
\text { Criminal sanctions can be also imposed upon individual management and board members } \\
\text { (Article } 104 \text { of the Banking Law ) but the NBB is not the competent authority for such } \\
\text { proceedings. }\end{array}$ \\
\hline \multicolumn{2}{|l|}{$\begin{array}{l}\text { Additional } \\
\text { criteria }\end{array}$} \\
\hline AC1 & $\begin{array}{l}\text { Laws or regulations guard against the supervisor unduly delaying appropriate corrective } \\
\text { actions. }\end{array}$ \\
\hline $\begin{array}{l}\text { Description and } \\
\text { findings re } A C 1\end{array}$ & $\begin{array}{l}\text { There are no laws or regulations in place that guard against the supervisor unduly delaying } \\
\text { appropriate corrective actions. In practice the NBB will contact the concerned credit } \\
\text { institution as soon as it is aware of non-compliance with laws and regulations or if there are } \\
\text { concerns with respect to the safety and soundness of the institution. } \\
\\
\text { The basic principle is that a credit institution in breach of the Banking Law and related } \\
\text { regulations has to be given a period of time to take corrective action. However, the law also } \\
\text { determines that recovery measures can be taken immediately in case of urgency. }\end{array}$ \\
\hline AC2 & $\begin{array}{l}\text { The supervisor has the power to take remedial actions, including ring-fencing of the bank } \\
\text { from the actions of parent companies, subsidiaries, parallel-owned banking structures and } \\
\text { other related companies in matters that could impair the safety and soundness of the bank. }\end{array}$ \\
\hline $\begin{array}{l}\text { Description and } \\
\text { findings re } A C 2\end{array}$ & $\begin{array}{l}\text { In accordance with Article } 57 \text { bis the NBB can formally initiate such actions, although its } \\
\text { recommendations need to be ratified through Royal Decree. } \\
\text { The NBB noted that given its strong powers under Article } 57 \text { and } 57 \text { bis, it has frequently } \\
\text { and recently been possible to use powers of suasion with an institution without resorting to }\end{array}$ \\
\hline
\end{tabular}




\begin{tabular}{|c|c|}
\hline & $\begin{array}{l}\text { full legal remedy. The assessors discussed instances and reviewed documentation } \\
\text { illustrating cases where the NBB had found such powers of suasion to be practical and } \\
\text { effective and the institution had complied with NBB recommendations on a "voluntary" } \\
\text { basis. }\end{array}$ \\
\hline AC3 & $\begin{array}{l}\text { When taking formal remedial action in relation to a bank, the supervisor ensures that the } \\
\text { regulators of non-bank related financial entities are aware of its actions and, where } \\
\text { appropriate, coordinates its actions with them. }\end{array}$ \\
\hline $\begin{array}{l}\text { Description and } \\
\text { findings re AC3 }\end{array}$ & $\begin{array}{l}\text { Article } 59 \text { imposes an obligation on the NBB to inform the FSMA or other relevant } \\
\text { supervisory authorities within the EEA of its actions under Articles } 56 \text { and } 57 \text { (i.e., } \\
\text { withdrawal of authorization and exceptional measures). The notification obligation set out } \\
\text { in Article } 59 \text { is ex post and not ex ante. The law does not impose an obligation to } \\
\text { cooperate and exchange information with supervisory authorities outside the EEA as } \\
\text { professional secrecy cannot be assumed but the NBB does seek to ensure that cooperation } \\
\text { arrangements are put in place. }\end{array}$ \\
\hline \begin{tabular}{|l|} 
Assessment of \\
Principle 23
\end{tabular} & Compliant \\
\hline Comments & $\begin{array}{l}\text { The NBB enjoys a broad range of powers and there is evidence that it is able and ready to } \\
\text { use such remedies. Moreover, the strong powers open to the NBB have clearly meant that } \\
\text { there are occasions where the supervisory authority has been able to use suasion rather } \\
\text { than needing to resort to legal remedies in the first instance. } \\
\text { The NBB has indicated it is at present examining the possibility of making its disciplinary } \\
\text { powers more graduated and proportionate to the severity of the offence committed by the } \\
\text { supervised institution. } \\
\text { Specifically, the NBB would like the Board to be able to impose periodic penalty payments } \\
\text { upon firms. At present, the NBB Organic Law (as amended by the Twin Peaks Royal Decree) } \\
\text { provides for the NBB Sanctions Committee to impose fines ("geldboete"/"amende") and } \\
\text { periodic penalty payments ("dwangsom"/"astreinte") upon the supervised institutions. } \\
\text { These two measures are seen as fundamentally different. Periodic penalty payments } \\
\text { ("dwangsom"/"astreinte") are intended to create an incentive to respect a requirement, } \\
\text { while the purpose of fines is to punish an illicit behavior on ex post basis. The procedures } \\
\text { and processes for submitting a case to the Sanctions Committee are much more elaborate, } \\
\text { as is fitting for the consideration of a "sanction" for a firm and various principles of due } \\
\text { process, such as separation of the prosecution process from the assessment process must } \\
\text { be observed (Articles } 36 / 9 \text { and seq. of the Organic Law of the NBB). However, in the law } \\
\text { governing the FSMA, (Law of August } 2 \text { nd } 2002 \text { as modified by the Twin Peaks Law of } 2 \text { July } \\
2010 \text { ), the imposition of periodic penalties is not classified as a formal sanction and } \\
\text { therefore such penalties can be imposed by the FSMA Board. Therefore it is now intended } \\
\text { to adopt a new law removing the qualification of "administrative sanction" from the } \\
\text { periodic penalty payments ("dwangsom"/"astreinte") in respect of the NBB, thus permitting } \\
\text { the NBB model to mirror that of the FSMA. }\end{array}$ \\
\hline
\end{tabular}

${ }^{6}$ Preparatory Documents, Parliament (Chambre des Représentants), 2001-2002, n50-1842/1, p. 288. 


\begin{tabular}{|c|c|}
\hline & $\begin{array}{l}\text { Also, it should be noted, there is draft EU legislation (the Capital Requirements Directive } \\
\text { "CRD IV") that is intended to introduce greater consistency between EU jurisdictions with } \\
\text { respect to sanctioning powers. }\end{array}$ \\
\hline Principle 24 & $\begin{array}{l}\text { Consolidated supervision. An essential element of banking supervision is that supervisors } \\
\text { supervise the banking group on a consolidated basis, adequately monitoring and, as } \\
\text { appropriate, applying prudential norms to all aspects of the business conducted by the } \\
\text { group worldwide. }\end{array}$ \\
\hline \multicolumn{2}{|l|}{ Essential criteria } \\
\hline EC1 & $\begin{array}{l}\text { The supervisor is familiar with the overall structure of banking groups and has an } \\
\text { understanding of the activities of all material parts of these groups, domestic and cross- } \\
\text { border. }\end{array}$ \\
\hline $\begin{array}{l}\text { Description and } \\
\text { findings re EC1 }\end{array}$ & 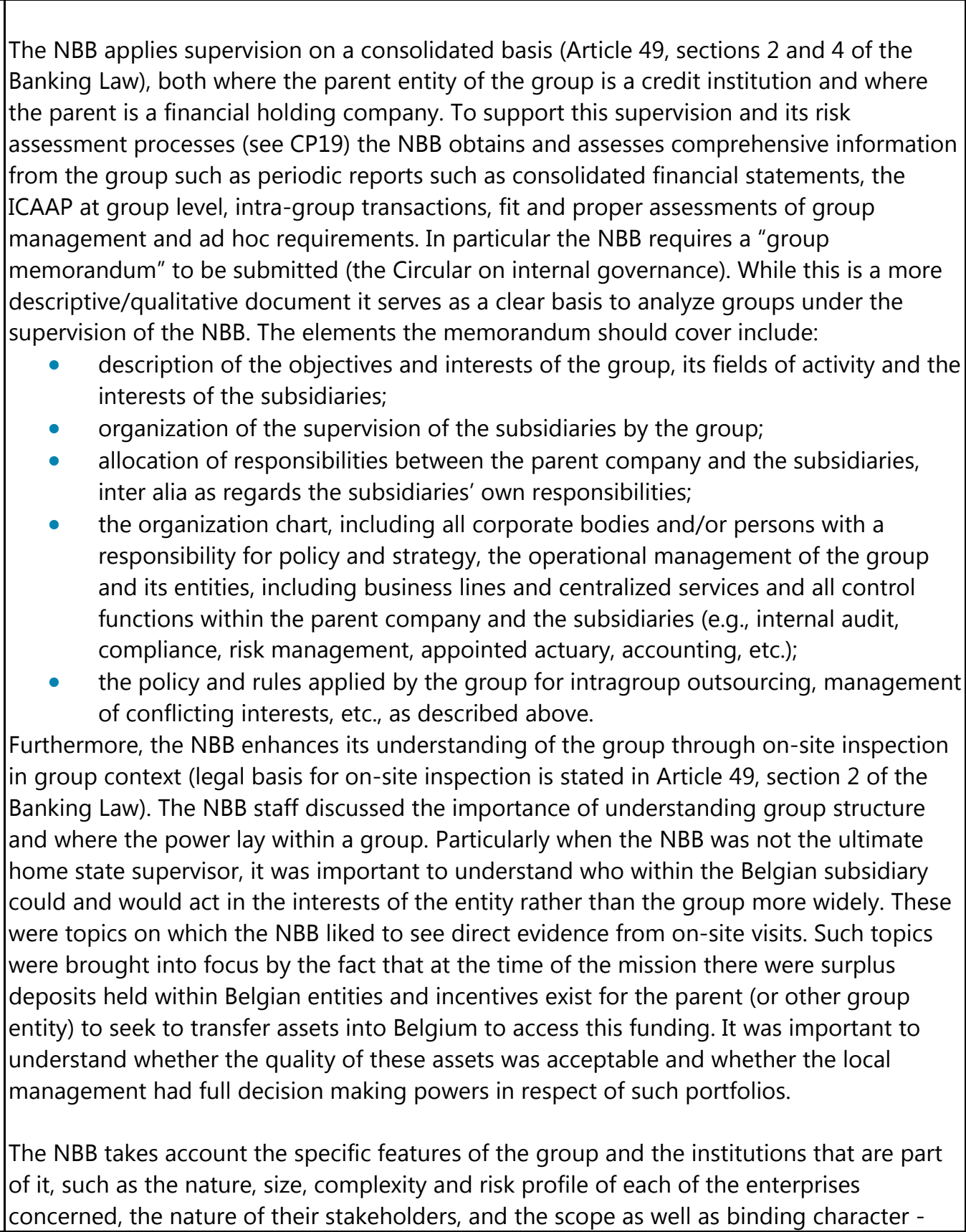 \\
\hline
\end{tabular}




\begin{tabular}{|c|c|}
\hline & $\begin{array}{l}\text { both from a legal and practical point of view - of the financial solidarity between the } \\
\text { entities of the group. } \\
\text { There are comprehensive legal and regulatory requirements placed on credit institutions } \\
\text { (such as Article } 20 \text { of the Banking Law and the Internal Governance Circular) to ensure that } \\
\text { their internal governance, controls and knowledge of their own group activities are } \\
\text { appropriate and that the group is able to provide all relevant information concerning the } \\
\text { group to the supervisory authority. }\end{array}$ \\
\hline $\mathrm{EC2}$ & $\begin{array}{l}\text { The supervisor has the power to review the overall activities of a banking group, both } \\
\text { domestic and cross-border. The supervisor has the power to supervise the foreign activities } \\
\text { of banks incorporated within its jurisdiction. }\end{array}$ \\
\hline & 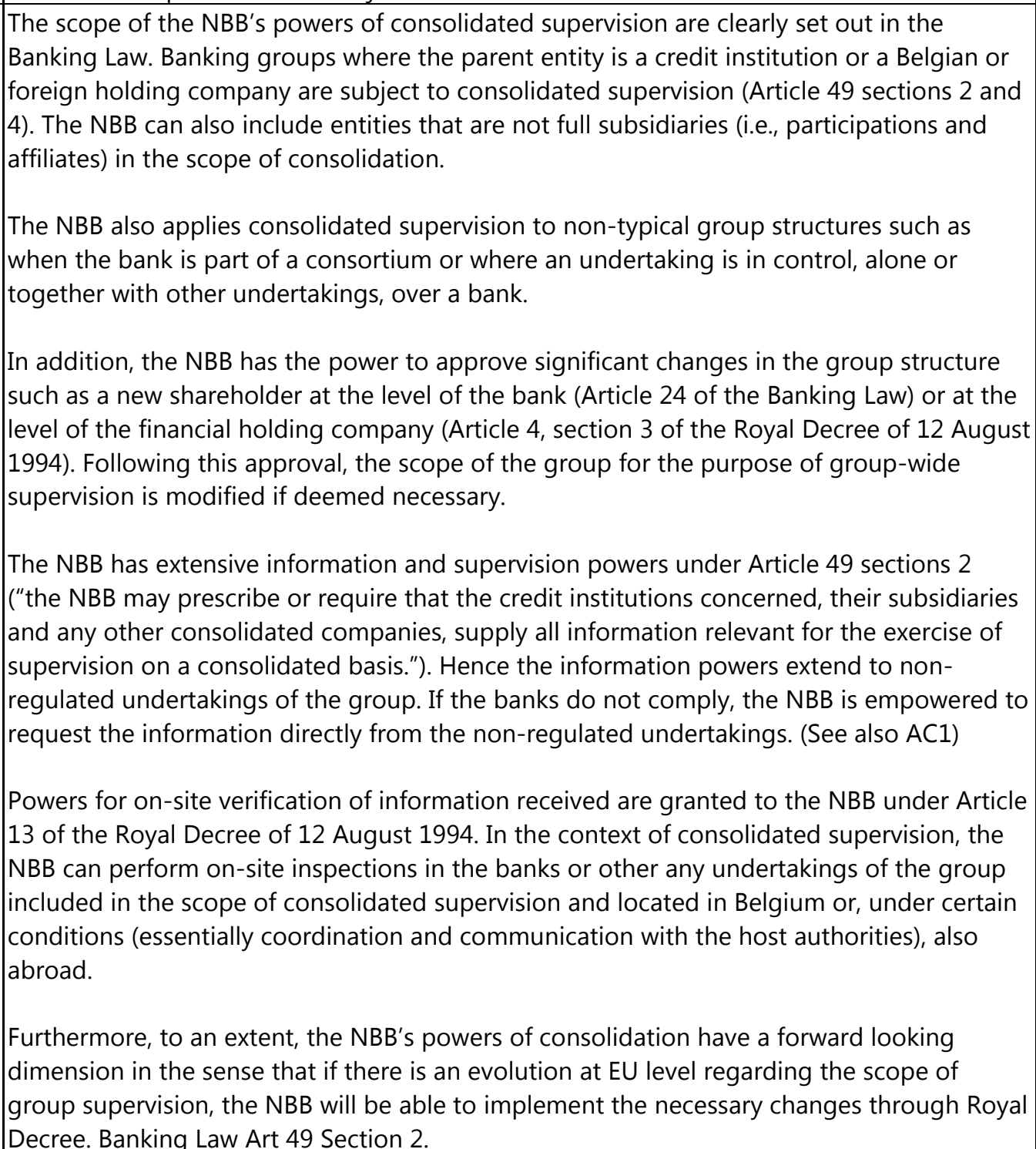 \\
\hline EC3 & $\begin{array}{l}\text { The supervisor has a supervisory framework that evaluates the risks that non-banking } \\
\text { activities conducted by a bank or banking group may pose to the bank or banking group. }\end{array}$ \\
\hline $\begin{array}{l}\text { Description and } \\
\text { findings re EC3 }\end{array}$ & $\begin{array}{l}\text { The Royal decree of } 12 \text { August } 1994 \text { (Article 1) gives a very broad basis to extend group } \\
\text { supervision to both regulated and unregulated entities. The scope of consolidation includes } \\
\text { banking sector entities (meaning "credit institutions," "investment firms" and "financial } \\
\text { institutions" as defined in Article } 1 \text { of the Royal Decree of } 12 \text { August 1994) but also }\end{array}$ \\
\hline
\end{tabular}


undertakings from other financial sectors (insurance companies, asset managers) and undertakings outside the financial sector.

The Royal Decree of 12 August 1994 also pays special attention to the relationship with insurance undertakings when part of the banking group, e.g., at the moment of licensing (Article 9, paragraph 2), for shareholder control purposes (Article 24 section 4), for solvency purposes (Article 2 section 3).

In instances where non-financial activities are part of a group, the Royal Decree of 12 August 1994 gives the NBB powers of group supervision over banks that are held by so called "mixed holdings" (Article8, 8bis and 9). A mixed holding company and all its subsidiaries must be able to give all the information needed to assess the influence on the bank(s). In particular there is scrutiny with respect to transactions between the bank and the mixed holding company or its subsidiaries. Should such transactions threaten the soundness of the bank, the NBB can put restrictions on them. Examples of such restrictions were discussed with the assessors. The assessors were also able to review group risk assessments incorporating analysis of non-banking risks within groups. The supervisors demonstrated a thorough understanding of the complex group structures in place and a familiarity with the non-banking entities within the group.

The Royal Decree of 21 November 2005 (based on Article 49bis of the Banking Law) considers the relationship between banks and insurance undertakings when part of the same group, as in this case the provisions of the EU Financial Groups Directive (re conglomerates) are likely to apply. Financial conglomerates are identified based on the definition of "financial conglomerate" in the Royal Decree of 21 November 2005 (see in particular Articles 1 and 2).

The Royal Decree of 12 August 1994 (Article 2, section 3) also considers the relationship with insurance undertakings when part of a banking group. If banks and insurance companies are part of the same group, the provisions of the EU Financial Groups Directive (re conglomerates) will apply. Financial conglomerates are identified based on the definition of "financial conglomerate" in the Royal Decree of 12 August 1994 (see in particular Articles 1 and 2).

With respect to conglomerate supervision, the NBB has a range of powers:

- Ownership of a financial conglomerate is subject to supervision in a similar manner to that applied in the sectoral regimes (Article 14 of the Royal Decree see also CP4)

- Directors and, where applicable, other senior management, of a mixed financial holding company must be fit and proper, (with reference to the sectoral fit and proper regulations).

- Access to and information from all regulated and unregulated entities that belong to the financial conglomerate "group," even if they are excluded from the scope of the supplementary supervision (Article 21 of the Royal Decree).

- The requirement of have sufficient transparency in the conglomerate cannot be explicitly derived from the Royal Decree, but is treated indirectly.

- Conglomerate supervision includes capital adequacy, risk concentration and intragroup transactions, and the internal control and risk management needed to support this (Article13 of the Royal Decree).

- Administrative sanctions towards regulated institutions that belong to a financial conglomerate (Article 27 of the Royal Decree), but also towards the mixed financial holding company, or towards a financial holding company or an insurance holding 


\begin{tabular}{|c|c|}
\hline & $\begin{array}{l}\text { company that are part of a financial conglomerate. The sanctioning power is set in } \\
\text { the context of "avoiding or trying to avoid sectoral regulation" and is thus } \\
\text { supplementary to sectoral sanctioning powers. } \\
\text { The Royal Decree also contains requirements for non-typical financial conglomerates, } \\
\text { ("other financial groups" as defined by Article } 18 \text { of the Royal Decree). Ultimately the NBB } \\
\text { has a legal basis for applying supplementary group supervision to any group structure } \\
\text { which contains at least one regulated entity. } \\
\text { When recent amendments in the European Financial Conglomerates Directive come into } \\
\text { force, it will be possible to apply the consolidated banking supervision and the } \\
\text { supplementary conglomerate group supervision together and at the same (highest) level in } \\
\text { a group that qualifies as a financial conglomerate. }\end{array}$ \\
\hline EC4 & $\begin{array}{l}\text { The supervisor has the power to impose prudential standards on a consolidated basis for } \\
\text { the banking group. The supervisor uses its power to establish prudential standards on a } \\
\text { consolidated basis to cover such areas as capital adequacy, large exposures, exposures to } \\
\text { related parties and lending limits. The supervisor collects consolidated financial information } \\
\text { for each banking group. }\end{array}$ \\
\hline $\begin{array}{l}\text { Description and } \\
\text { findings re EC4 }\end{array}$ & $\begin{array}{l}\text { The NBB has the power to impose prudential standards on a consolidated basis through } \\
\text { the Banking Law (Article 49). Consolidated supervision covers the following areas: } \\
\text { the soundness of the financial position of the consolidated group as a whole, } \\
\text { based on the consolidated periodic reports; } \\
\text { the governance of the group (such as (i) intragroup transactions, (ii) appropriate } \\
\text { risk management and internal control procedures, (iii) the qualities required of the } \\
\text { shareholders, (iv) the "four eyes" principle for management, including fitness and } \\
\text { probity and the qualities required of the senior management, and (v) the statutory } \\
\text { auditor's tasks. } \\
\text { assessment of the influence on each other exercised by the companies included in } \\
\text { the consolidation scope, primarily of course the influence on the banks; } \\
\text { - limitations on holdings and participations by banks } \\
\text { solvency and risk concentration, as well as the requirement to have an appropriate } \\
\text { internal capital adequacy assessment policy } \\
\text { certain publication requirements (see Article 20ter of the Banking Law ) } \\
\text { The NBB participates in colleges with other supervisors, reaching joint decisions on (e.g.,) } \\
\text { the capital adequacy of cross boarder groups on consolidated and solo basis. }\end{array}$ \\
\hline EC5 & $\begin{array}{l}\text { The supervisor has arrangements with other relevant supervisors, domestic and cross- } \\
\text { border, to receive information on the financial condition and adequacy of risk management } \\
\text { and controls of the different entities of the banking group. }\end{array}$ \\
\hline $\begin{array}{l}\text { Description and } \\
\text { findings re EC5 }\end{array}$ & $\begin{array}{l}\text { There is supporting legal framework for the cooperation, coordination and joint work of the } \\
\text { relevant supervisory authorities in relation to consolidated supervision. } \\
\text { Royal Decree of } 12 \text { August } 1994 \text { (Articles } 9 \text { bis to } 13 \text { ) sets out the cooperation arrangements } \\
\text { that the NBB can and must establish with other supervisory authorities, both within the EU } \\
\text { and outside the EU, in order to exercise consolidated banking supervision. }\end{array}$ \\
\hline
\end{tabular}




\begin{tabular}{|c|c|}
\hline & 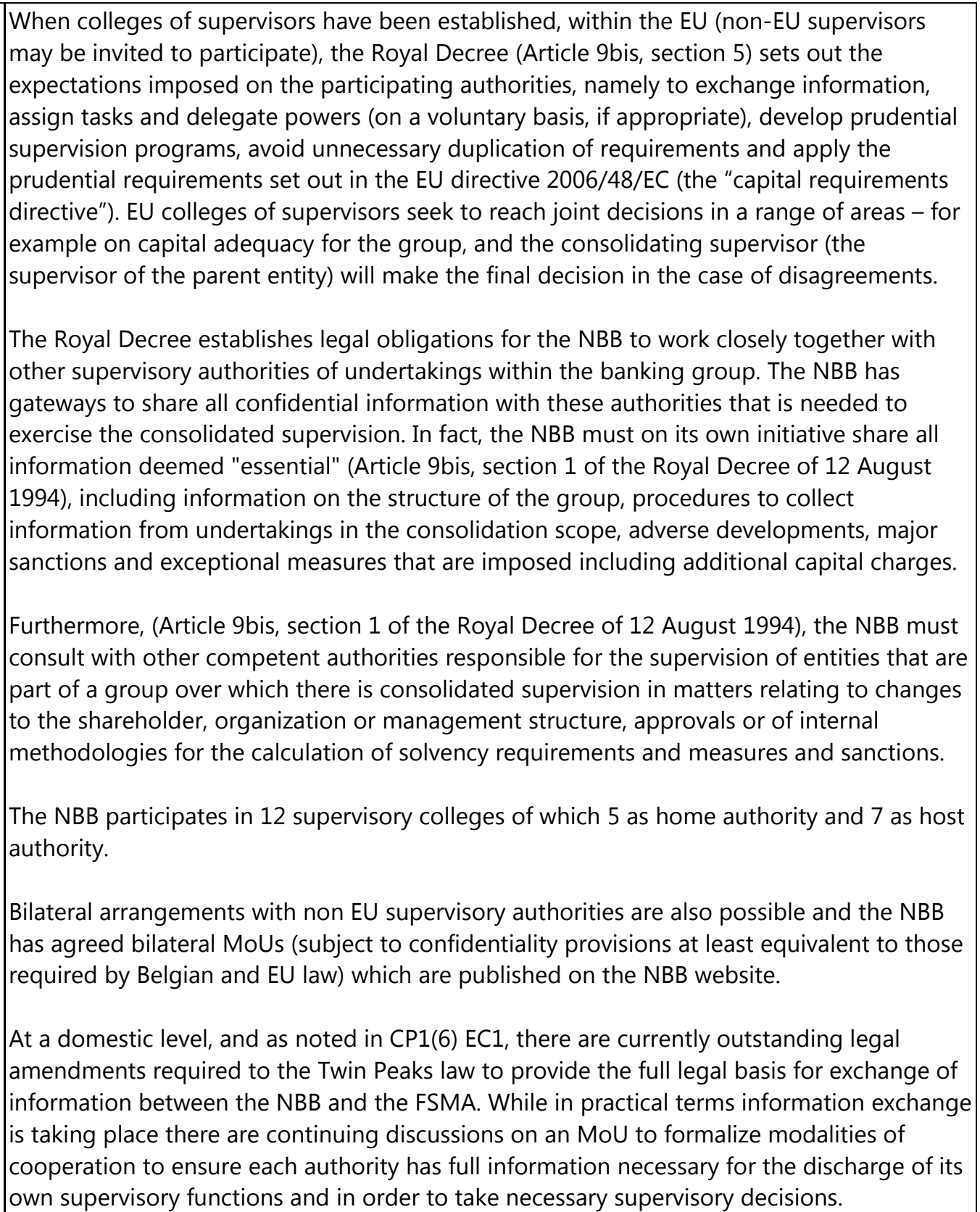 \\
\hline EC6 & $\begin{array}{l}\text { The supervisor has the power to limit the range of activities the consolidated group may } \\
\text { conduct and the locations in which activities can be conducted; the supervisor uses this } \\
\text { power to determine that the activities are properly supervised and that the safety and } \\
\text { soundness of the bank are not compromised. }\end{array}$ \\
\hline $\begin{array}{l}\text { Description and } \\
\text { findings re EC6 }\end{array}$ & $\begin{array}{l}\text { The NBB has powers under the Banking Law (Article } 57 \text { and } 57 \text { bis, see also CP23) to impose } \\
\text { measures, including prohibition of the exercise of certain activities of the bank. This power } \\
\text { can be applied in the context of groupwide activities. } \\
\text { The NBB has the power to block banking groups' projects to acquire or to establish } \\
\text { subsidiaries or branches (notably through Articles } 30 \text { and 34), if such projects threaten the } \\
\text { safe and sound conduct of the group or increases the risk profile of that group beyond its } \\
\text { risk bearing capacity. }\end{array}$ \\
\hline
\end{tabular}




\begin{tabular}{|c|c|}
\hline & $\begin{array}{l}\text { For banks or financial holding companies that are recognized as domestic systemically } \\
\text { important firms, there are specific provisions on the approval that the NBB needs to give at } \\
\text { the occasion of strategic decisions, such as the range of activities of the group (Article } 36 / 3 \\
\text { of the Organic Law NBB). } \\
\text { The NBB also analyses all material disposals in order to assess the impact on the risk profile } \\
\text { of the group, as well as on the sustainability of the overall business model of the group and } \\
\text { its future profitability. } \\
\text { Importantly, the setting up of an subsidiary abroad requires notification to the NBB (Article } \\
33 \text { bis of the Banking Law). While there are no explicit powers of approval or refusal, the } \\
\text { NBB must be mindful of the fact that a group structure may never hinder the prudential } \\
\text { supervision over the bank(s) (Article } 20 \text {, section } 7 \text { of the Banking Law) and may thus oppose } \\
\text { the establishment of a subsidiary. } \\
\text { Additionally it may be noted that Article } 32 \text { of the Banking Law, which applies on a } \\
\text { consolidated level, sets limits on the nature of the shareholdings a bank can hold, thus } \\
\text { imposing a structural limitation on the range of activities the bank can participate in } \\
\text { through its group. } \\
\text { For limitations on intragroup exposures, see EC } 2 \text { of Principle } 10 .\end{array}$ \\
\hline EC7 & $\begin{array}{l}\text { The supervisor determines that management is maintaining proper oversight of the bank's } \\
\text { foreign operations, including branches, joint ventures and subsidiaries. The supervisor also } \\
\text { determines that banks' policies and processes ensure that the local management of any } \\
\text { cross-border operations has the necessary expertise to manage those operations in a safe } \\
\text { and sound manner and in compliance with supervisory and regulatory requirements. }\end{array}$ \\
\hline $\begin{array}{l}\text { Description and } \\
\text { findings re } E C 7\end{array}$ & $\begin{array}{l}\text { Banks are required to have in place appropriate governance mechanisms at group level } \\
\text { (Article } 20 \text { of the Banking Law). These must ensure that information within the group is } \\
\text { share both bottom up and top down. Branches and subsidiaries should be included in } \\
\text { group-wide internal control and risk management procedures. Also fit and proper policies } \\
\text { must be in place at group-wide level. } \\
\text { The principles laid down in the Internal Governance Circular (PPB-2007-6) are applied to } \\
\text { parent companies subject to NBB supervision and to their Belgian regulated subsidiaries. } \\
\text { The Internal Governance Circular states: "Although group supervision as applied to groups } \\
\text { whose activity presents an international dimension and whose structure includes entities } \\
\text { governed by various jurisdictions is by nature more complex than that of purely national } \\
\text { groups, the fundamental principles remain. However, such group supervision requires } \\
\text { international consultation and must, in accordance with the provisions of the supervisory } \\
\text { laws and/or bilateral or multilateral agreements, duly take into account the different rules } \\
\text { and supervisory schemes to which certain entities are subject." } \\
\text { The NBB expects that the mechanisms applied to address group wide risks are also applied } \\
\text { to foreign subsidiaries whether or not they are regulated entities. Also, group governance } \\
\text { and control are without prejudice to the application of any local supervisory rules to which } \\
\text { these foreign subsidiaries may be subject. }\end{array}$ \\
\hline
\end{tabular}




\begin{tabular}{|c|c|}
\hline & $\begin{array}{l}\text { In practice the supervisory colleges provide a structured framework to discuss group wide } \\
\text { risks including internal controls and risk management. }\end{array}$ \\
\hline EC8 & $\begin{array}{l}\text { The supervisor determines that oversight of a bank's foreign operations by management } \\
\text { (of the parent bank or head office and, where relevant, the holding company) includes: (i) } \\
\text { information reporting on its foreign operations that is adequate in scope and frequency to } \\
\text { manage their overall risk profile and is periodically verified; (ii) assessing in an appropriate } \\
\text { manner compliance with internal controls; and (iii) ensuring effective local oversight of } \\
\text { foreign operations. } \\
\text { For the purposes of consolidated risk management and supervision, there should be no } \\
\text { hindrance in host countries for the parent bank to have access to all the material } \\
\text { information from their foreign branches and subsidiaries. Transmission of such information } \\
\text { is on the understanding that the parent bank itself undertakes to maintain the } \\
\text { confidentiality of the data submitted and to make them available only to the parent } \\
\text { supervisory authority. }\end{array}$ \\
\hline $\begin{array}{l}\text { Description and } \\
\text { findings re EC8 }\end{array}$ & $\begin{array}{l}\text { There are obligations placed on the senior management of both a parent bank or a } \\
\text { financial holding company in respect of the group's internal controls and risk management } \\
\text { (see also CP17) and for the verification of the completeness and accuracy of group } \\
\text { reporting (Article } 6 \text { section } 3 \text { of the Royal Decree of } 12 \text { August 1994). Furthermore the } \\
\text { Royal Decree of } 12 \text { August } 1994 \text { (Article 12) requires free information flow between all the } \\
\text { entities in the consolidation scope, including the financial holding company and any } \\
\text { subsidiaries, even those that may have been excluded from the scope of consolidation, or } \\
\text { which represent a minority interest within the consolidated group. In respect of information } \\
\text { sharing within the group, the NBB adopt the Basel Committee paper on "Know your } \\
\text { customer" risk management (2004) as a main reference. } \\
\text { Assessing and evaluating the internal controls and management of a group comes within } \\
\text { the overall risk assessment carried out by the NBB. This includes the scope of the internal } \\
\text { controls throughout the group, the groupwide organization and conduct of risk } \\
\text { management, the quality of management information and the review carried out by } \\
\text { management. In particular the NBB checks the group internal governance memorandum to } \\
\text { assess whether the group has the necessary internal arrangements for an optimal intra- } \\
\text { group flow of information, that may, if necessary, overcome any such restrictions e.g., } \\
\text { through contractual agreements between the bank / financial holding and an entity in } \\
\text { which it has just a participation. Specifically, paragraph } 99 \text {, point ii of the Internal } \\
\text { governance Circular requires that the group internal governance memorandum must } \\
\text { explain how the steering of the group shall be performed and how the bank / financial } \\
\text { holding company will supervise its subsidiaries (where "subsidiaries" can be understood in } \\
\text { a broad sense, as including all the entities in the prudential consolidation scope). } \\
\text { In the event of restriction on the flow of information within the group, the NBB has } \\
\text { remedial measures (notably under Articles } 57 \text { and } 57 \text { bis) which would permit it to restrict } \\
\text { activities or, under certain circumstances (jeopardizing financial stability) require the } \\
\text { disposal of the subsidiary or business lines in question. }\end{array}$ \\
\hline EC9 & $\begin{array}{l}\text { The home supervisor has the power to require the closing of foreign offices, or to impose } \\
\text { limitations on their activities, if: } \\
\text { it determines that oversight by the bank and/or supervision by the host supervisor } \\
\text { is not adequate relative to the risks the office presents; and/or } \\
\text { it cannot gain access to the information required for the exercise of supervision on } \\
\text { a consolidated basis. }\end{array}$ \\
\hline Description and & The NBB has powers to restrict activities, or even when financial stability issues are a \\
\hline
\end{tabular}




\begin{tabular}{|c|c|}
\hline findings re EC9 & $\begin{array}{l}\text { concern, to require disposals (Articles } 57 \text { and } 57 \text { bis of the Banking Law ). In a cross-border } \\
\text { context there would be coordination with the host and within the EU the directives provide } \\
\text { a structure for such coordination, including a binding mediation mechanism in case of } \\
\text { disputes. } \\
\text { The NBB's experience of colleges is that host supervisors generally cooperate with the } \\
\text { home supervisor. In its capacity of home supervisor the NBB aims to make at least an } \\
\text { annual visit to the host supervisor and the local entity when the risks of that local entity are } \\
\text { material from the group perspective. Such bilateral visits have been felt to enhance the } \\
\text { mutual trust and understanding amongst supervisors and the on-site meetings at the } \\
\text { premises of the local entity have provided good insights into the quality of the local } \\
\text { management and its organization. (See also AC3). } \\
\text { In instances where the subsidiary is not regulated, if the group does not cooperate in } \\
\text { providing the information on that subsidiary, the NBB would contemplate closing the } \\
\text { entity, on top of a prudential enforcement action against the group for its lack of } \\
\text { cooperation and/or supervision of its local non-regulated entity. }\end{array}$ \\
\hline EC10 & $\begin{array}{l}\text { The supervisor confirms that oversight of a bank's foreign operations by management (of } \\
\text { the parent bank or head office and, where relevant, the holding company) is particularly } \\
\text { close when the foreign activities have a higher risk profile or when the operations are } \\
\text { conducted in jurisdictions or under supervisory regimes differing fundamentally from those } \\
\text { of the bank's home country. }\end{array}$ \\
\hline $\begin{array}{l}\text { Description and } \\
\text { findings re EC10 }\end{array}$ & $\begin{array}{l}\text { The legal framework, (Article 9bis, section } 5 \text { of the Royal Decree of } 12 \text { August 1994) } \\
\text { imposes an explicit task upon the NBB, when it is consolidating supervisor, to plan the } \\
\text { supervisory activities for the group based on the group's risk profile, involving other } \\
\text { relevant authorities as appropriate. } \\
\text { The Banking Law and secondary regulation also provides a clear framework of expectation } \\
\text { on the bank's management that it must have in place a consolidated oversight of the } \\
\text { group structure, activities and the risks of its subsidiaries and branches. The management } \\
\text { must ensure on a group wide basis, for example, appropriate organization, governance, risk } \\
\text { management, compliance, and internal audit. (Article } 20 \text { sections 1-2 of the Banking Law } \\
\text { and the Internal Governance Circular). } \\
\text { While there is no single technique the NBB employs to determine the appropriate scope } \\
\text { and intensity of the firm's own risk-based management, the supervisor reaches its } \\
\text { assessment through the operation of the overall supervisory program (see also CP19 and } \\
\text { 20). The starting point is that input from the bank's management should be risk-based. } \\
\text { ICAAP reporting, as required by NBB Circulars, must be performed on solo and group-wide } \\
\text { basis (see also CP7), and internal control statements must be drawn up on solo and group- } \\
\text { wide basis (see also CP17). The NBB Circulars clarify that the bank's / group's management } \\
\text { must not only identify risks, but also assess them and take into account their relative } \\
\text { importance for the overall risk profile of the group. } \\
\text { As discussed in CP17 the NBB's supervisory program pays specific attention to the group's } \\
\text { organization of its internal control functions. This will be reflected in the scorecarding } \\
\text { approach. The NBB requests that all material group entities have independent audit, risk } \\
\text { management and compliance functions that report to the group wide functions in addition } \\
\text { to the senior management and board at the subsidiary level. The audit committee, risk } \\
\text { committee or other specialized committees of the Board should have a groupwide scope } \\
\text { and appropriate arrangements for the flow and exchange of information. Importantly the }\end{array}$ \\
\hline
\end{tabular}




\begin{tabular}{|c|c|}
\hline & $\begin{array}{l}\text { group must have procedures to escalate material governance, risk, audit or compliance } \\
\text { issues as necessary. } \\
\text { The NBB applies the principle of proportionality in its supervisory evaluation approach and } \\
\text { this approach informs the consideration of the cross-border activities of consolidated } \\
\text { groups. The NBB discussed a range of examples where specific risks and issues had been of } \\
\text { concern and had resulted in follow up action including on-site visits by the NBB to non- } \\
\text { domestic entities. } \\
\text { See also above for the principle on offshore activities / know your structure principle (EC 1). }\end{array}$ \\
\hline \multicolumn{2}{|l|}{$\begin{array}{l}\text { Additional } \\
\text { criteria }\end{array}$} \\
\hline AC1 & $\begin{array}{l}\text { For those countries that allow corporate ownership of banking companies: } \\
\text { - the supervisor has the power to review the activities of parent companies and of } \\
\text { companies affiliated with the parent companies, and uses the power in practice to } \\
\text { determine the safety and soundness of the bank; and } \\
\text { - } \quad \text { the supervisor has the power to establish and enforce fit and proper standards for } \\
\text { owners and senior management of parent companies. }\end{array}$ \\
\hline $\begin{array}{l}\text { Description and } \\
\text { findings re } A C 1\end{array}$ & $\begin{array}{l}\text { Although the financial holding companies and non-regulated subsidiaries are included in } \\
\text { the scope of consolidated banking supervision, this does not mean they can be supervised } \\
\text { on a solo stand-alone basis. However, as noted in EC2, the NBB has extensive information } \\
\text { and review powers in the context of its consolidated banking supervision. } \\
\text { If the non-regulated entities are non-domestic the NBB can demand the information } \\
\text { through the Belgian regulated entities. Where the information is already available with } \\
\text { another authority, however, the NBB would seek to request the information through that } \\
\text { channel to the extent possible. } \\
\text { Importantly, even subsidiaries that are not included in the scope of consolidation must be } \\
\text { able to provide information to the supervisor when needed (Article } 10 \text { of the Royal Decree } \\
\text { of } 12 \text { August 1994). } \\
\text { The NBB can make on-site inspections in all entities mentioned in the paragraph above. } \\
\text { Where the entity is non-domestic, the NBB will of course coordinate with the foreign } \\
\text { authorities as appropriate (see Article } 13 \text { the Royal Decree of } 12 \text { August 1994) } \\
\text { As discussed under CP4 the NBB has powers to consider change in the ownership of an } \\
\text { institution, including ultimate beneficial owner (Article } 24 \text { of the Banking Law; Article } 4 \text {, } \\
\text { section } 3 \text { of the Royal Decree of } 12 \text { August } 1994 \text { ). } \\
\text { Executive (or where applicable other senior management) and non-executive directors of } \\
\text { financial holding companies must be fit and proper (Article } 4 \text { section } 4 \text { of the Royal Decree } \\
\text { of } 12 \text { August 1994; see also principle EC } 8 \text { of BCP } 3 \text { ). }\end{array}$ \\
\hline AC2 & $\begin{array}{l}\text { The home supervisor assesses the quality of supervision conducted in the countries in } \\
\text { which its banks have material operations. }\end{array}$ \\
\hline $\begin{array}{l}\text { Description and } \\
\text { findings re AC2 }\end{array}$ & $\begin{array}{l}\text { The harmonized legal framework for consolidated supervision set out in EU legislation } \\
\text { contains the concept of "mutual recognition" and therefore the NBB does not formally } \\
\text { assess the quality of supervision conducted in EU/EEA Member States. }\end{array}$ \\
\hline
\end{tabular}




\begin{tabular}{|c|c|}
\hline & $\begin{array}{l}\text { With respect to non-EU/EEA jurisdictions, there is legal provision (Article } 7 \text { bis section } 2 \text { of } \\
\text { the Royal Decree of } 12 \text { August 1994) that requires the NBB to assess whether the parent of } \\
\text { the regulated Belgian institution is subject to consolidated supervision that is equivalent to } \\
\text { supervision standards set out in the Decree. The NBB shall consult with the other EU/EEA } \\
\text { competent authorities on the equivalence that consolidated supervision also taking into } \\
\text { account any guideline issued by the European Banking Committee. }\end{array}$ \\
\hline AC3 & $\begin{array}{l}\text { The supervisor arranges to visit the foreign locations periodically, the frequency being } \\
\text { determined by the size and risk profile of the foreign operation. The supervisor meets the } \\
\text { host supervisors during these visits. The supervisor has a policy for assessing whether it } \\
\text { needs to conduct on-site examinations of a bank's foreign operations, or require additional } \\
\text { reporting, and has the power and resources to take those steps as and when appropriate. }\end{array}$ \\
\hline $\begin{array}{l}\text { Description and } \\
\text { findings re } A C 3\end{array}$ & $\begin{array}{l}\text { In its capacity of home supervisor the NBB aims, in principle, to visit the non-domestic } \\
\text { jurisdictions, which are material for the Belgian banking group. A typical visit comprises a } \\
\text { meeting with the local supervisors in order to discuss in detail the risk profile and } \\
\text { assessment of the subsidiary, as well as a joint visit at the premises of the subsidiary for in- } \\
\text { depth discussions with the local management of the bank. Such visits are in addition to } \\
\text { periodic college meetings. } \\
\text { Furthermore, whether as the home or host supervisor for groups with EU/EEA parent } \\
\text { entities, the NBB participates in the annual global risk assessment of the consolidated } \\
\text { group that is coordinated by the consolidating supervisor. } \\
\text { The NBB regularly conducts joint on-site examinations at parent and local level and } \\
\text { employs a proportionate risk based approach. This is common practice in the field of ICAAP } \\
\text { assessments and IRB model validation. Themes of joint inspections have included } \\
\text { governance and internal control functions. The assessors were able to review } \\
\text { documentation covering regular visits by the NBB team for a systemic bank to the most } \\
\text { material foreign subsidiaries. }\end{array}$ \\
\hline $\begin{array}{l}\text { Assessment of } \\
\text { Principle } 24 \\
\end{array}$ & Compliant \\
\hline Comments & $\begin{array}{l}\text { The NBB has the necessary legal powers and has implemented the necessary regulatory } \\
\text { structure to facilitate the practice of consolidated supervision. An effective practice of } \\
\text { consolidated supervision depends not only on legal framework and access to data but also } \\
\text { on the relationships with other relevant supervisory authorities for the consolidated group } \\
\text { and this dimension is highly relevant to the Belgian authorities given the cross border } \\
\text { nature of the systemically relevant groups. } \\
\text { The evolution of the international regulatory framework, particularly at the EU level with the } \\
\text { introduction of more structured colleges of supervisors (see also CP25) has provided a } \\
\text { vehicle for an enhanced oversight of consolidated groups that operate on a cross border } \\
\text { basis. The NBB is actively using the college environment to create opportunities to test out } \\
\text { the quality of risk focused management within groups by their own management as well as } \\
\text { to ensure an adequate distribution of capital within the group. The NBB noted that } \\
\text { governance requirements for groups could be enhanced by stating more explicitly what is } \\
\text { expected of the parent company in respect of coordinating and controlling the group in a } \\
\text { holistic way. The assessors agree and would encourage the NBB to act on this. }\end{array}$ \\
\hline
\end{tabular}




\begin{tabular}{|c|c|}
\hline & $\begin{array}{l}\text { International regulatory reform is increasingly turning the spotlight on the regulatory } \\
\text { perimeter, which may affect the future scope of consolidation. The regulatory agenda also } \\
\text { encourages the greater understanding of the interaction of risks within larger and more } \\
\text { diverse groups. In the context of consolidated supervision the challenge is to ensure that } \\
\text { non-banking and, as necessary, non-financial risks within the group are fully understood, } \\
\text { even though these risks may appear present within only a small part of the group. The } \\
\text { ability to communicate and cooperate effectively with all domestic regulators as well as } \\
\text { international authorities is critical to this task. It is therefore recommended (as also noted in } \\
\text { CP 1(6)) that the NBB and the FSMA quickly finalise the MoU setting out the modalities of } \\
\text { cooperation. } \\
\text { Consolidated supervision comes under stress at time of crisis and during a crisis period not } \\
\text { all significant decisions will necessarily be made within the purely supervisory community. } \\
\text { Indeed there are separate arrangements for crisis management even if the supervisory } \\
\text { authorities prepare the groundwork for other national authorities (notably ministries) to } \\
\text { make key decisions. The methodology does not require comment on the extent or } \\
\text { effectiveness of supervisory cooperation in crisis conditions but it is noted that the financial } \\
\text { crisis wrought significant change on the structure of the Belgian financial system leading to } \\
\text { the NBB becoming not only the home but also the host supervisory authority for systemic } \\
\text { groups active in Belgium. In respect of consolidated supervisory practices, it is to the } \\
\text { considerable credit of the NBB that it has managed this transition well so far. }\end{array}$ \\
\hline Principle 25 & $\begin{array}{l}\text { Home-host relationships. Cross-border consolidated supervision requires cooperation } \\
\text { and information exchange between home supervisors and the various other supervisors } \\
\text { involved, primarily host banking supervisors. Banking supervisors must require the local } \\
\text { operations of foreign banks to be conducted to the same standards as those required of } \\
\text { domestic institutions. }\end{array}$ \\
\hline \multicolumn{2}{|l|}{ Essential criteria } \\
\hline EC1 & $\begin{array}{l}\text { Information to be exchanged by home and host supervisors should be adequate for their } \\
\text { respective roles and responsibilities. }\end{array}$ \\
\hline $\begin{array}{l}\text { Description and } \\
\text { findings re EC1 }\end{array}$ & $\begin{array}{l}\text { The supervision of cross-border banking groups and the home-host relationship are } \\
\text { governed by the relevant European directives on prudential supervision of banks (notably } \\
\text { directive } 2006 / 48 / E C \text { and its subsequent amendments), which have been transposed into } \\
\text { Belgian legislation. In fact the EBA has drafted a template for multilateral cooperation and } \\
\text { coordination agreements for EU/EEA groups, although supervisors from non EU/EEA } \\
\text { jurisdictions are not excluded. } \\
\text { As governed by the directives, there is a structured framework for exchange of information } \\
\text { to support the work of colleges of supervisors (e.g., preparation of joint risk assessment } \\
\text { and joint capital decision; follow-up of college meetings) and legal gateways to facilitate } \\
\text { the exchange of prudential information on the supervisor's own initiative. } \\
\text { This information sharing is mostly, but not exclusively, related to the following topics: } \\
\text { strategy and activities of the group, changes in the group structure or the business model, } \\
\text { EC restructuring plan, financial situation, prudential ratios and risk profile, model validation, } \\
\text { ICAAP, EBA stress tests, findings of on-site inspections. In crisis situations, such sharing of } \\
\text { information will have a higher frequency and will be more comprehensive, intensive and } \\
\text { focused. }\end{array}$ \\
\hline
\end{tabular}




\begin{tabular}{|c|c|}
\hline & $\begin{array}{l}\text { In accordance with European law (see the amendments to Directive } 2006 / 48 / E C \text { ) EU } \\
\text { colleges have, since } 2011 \text {, been required to make a joint risk assessment, and a joint ICAAP } \\
\text { assessment for each cross-border group. This assessment process (SREP) must lead to a } \\
\text { joint decision regarding the capital adequacy of the group and the minimum capital } \\
\text { requirements that each entity within the group must hold. This risk assessment constitutes } \\
\text { the basis of the joint home/host supervisory plan. } \\
\text { The practice of information sharing is well established. A regular information exchange } \\
\text { during and in between meetings contributes to the spirit of cooperation amongst college } \\
\text { members. Mutual trust and building supervisory relationships are seen as key for effective } \\
\text { information sharing. } \\
\text { The assessors discussed exchanges of information and college practices with the NBB and } \\
\text { were able to review extensive documentation illustrating the range and depth of } \\
\text { information exchange. }\end{array}$ \\
\hline EC2 & $\begin{array}{l}\text { For material cross-border operations of its banks, the supervisor identifies all other relevant } \\
\text { supervisors and establishes informal or formal arrangements (such as memoranda of } \\
\text { understanding) for appropriate information sharing, on a confidential basis, on the financial } \\
\text { condition and performance of such operations in the home or host country. Where formal } \\
\text { cooperation arrangements are agreed, their existence should be communicated to the } \\
\text { banks and banking groups affected. }\end{array}$ \\
\hline $\begin{array}{l}\text { Description and } \\
\text { findings re EC2 }\end{array}$ & $\begin{array}{l}\text { In its capacity as home supervisor, the NBB has carried out a mapping exercise identifying } \\
\text { all EEA and non-EEA subsidiaries and branches within a group in order to set up and } \\
\text { organise the relevant supervisory colleges in accordance with the organization, scale and } \\
\text { complexity of the group. This exercise is intended to determine which supervisors should } \\
\text { become member of the college and be invited to sign the college MoU laying out the basis } \\
\text { for the functioning of the college (including regarding the exchange of confidential } \\
\text { information). Whereas the EEA members are required to sign a formal MoU for the } \\
\text { supervision of a EEA-bank of banking group, non-EEA members participate in the colleges } \\
\text { on the basis of either formal bilateral MoU's with the home supervisor (and other hosts), an } \\
\text { exchange of letters or informal arrangements for the day-to-day conduct of the college } \\
\text { work. As noted above the NBB participates in } 12 \text { supervisory colleges of which } 5 \text { as home } \\
\text { authority and } 7 \text { as host authority. The NBB has signed } 26 \text { MoUs altogether, of which } 18 \text { are } \\
\text { intra-EU (this excludes insurance MoUs). } \\
\text { The NBB informs the (banking) group of the setting of the college and the agenda of the } \\
\text { meetings and debriefs the group on the main conclusions. Senior management of the } \\
\text { group is regularly invited to attend part of the college meetings in order to provide } \\
\text { information on the group (e.g., status of restructuring plan and strategy, main risks of the } \\
\text { group, the impact of Basel III) to all participating host supervisors. The banks with whom } \\
\text { the assessors met commented positively on their experience of being involved in and } \\
\text { informed of college processes by the NBB. }\end{array}$ \\
\hline
\end{tabular}




\begin{tabular}{|c|c|}
\hline EC3 & $\begin{array}{l}\text { The home supervisor provides information to host supervisors, on a timely basis, } \\
\text { concerning: } \\
\text { the overall framework of supervision in which the banking group operates; } \\
\text { the bank or banking group, to allow a proper perspective of the activities } \\
\text { conducted within the host country's borders; } \\
\text { the specific operations in the host country; and } \\
\text { other ports of the banking group if these are likely to have a material effect on the } \\
\text { safety and soundness of subsidiaries or branches in host countries. } \\
\text { A minimum level of information on the bank or banking group will be needed in most } \\
\text { circumstances, but the overall frequency and scope of this information will vary depending } \\
\text { on the materiality of a bank's or banking group's activities to the financial sector of the } \\
\text { host country. In this context, the host supervisor will inform the home supervisor when a } \\
\text { local operation is material to the financial sector of the host country. }\end{array}$ \\
\hline $\begin{array}{l}\text { Description and } \\
\text { findings re EC3 }\end{array}$ & $\begin{array}{l}\text { The exchange of information is one of the main tasks of the college and the NBB (as home } \\
\text { supervisor) puts effort into optimizing the information exchange of key information to the } \\
\text { college members. The NBB's experience is that current practices of exchange of } \\
\text { information at college meetings relate to standard topics and are generally deemed } \\
\text { adequate. Typically, at college meetings, each college member will give a presentation of } \\
\text { the risk assessment of the entity, which falls under its supervision. This assessment will } \\
\text { include an estimate of the materiality of those risks for the group. College meetings also } \\
\text { typically collect and share information on the planned supervisory actions of each } \\
\text { supervisor. } \\
\text { As a home supervisor, the NBB's main focus is upon the following: } \\
\quad \text { functioning of the college in conformity with the European or international } \\
\text { regulation, and according to observed good practices; } \\
\quad \text { finalisation of a joint risk assessment, joint ICAAP assessment and of a joint capital } \\
\quad \text { joint home/host supervisory plan; and the execution of joint on and off site } \\
\text { investigations; } \\
\text { set up of infrastructure to deal with important crises; } \\
\quad \text { extension of the role and competence of the college to new topics, including } \\
\quad \text { macro-prudential control, IT risks and non-financial risks; and } \\
\quad \text { EBA stress-tests. } \\
\text { Once a year, each college summarises in a formal joint risk assessment report all the } \\
\text { material risks to which the group and its entities are exposed. This report is extensively } \\
\text { discussed and endorsed by the participating supervisors. (See also EC1 above) } \\
\text { The NBB uses the full range of communication channels to enable a continuous and timely } \\
\text { exchange of information on the group structure and activities, the main risks and financial } \\
\text { position (liquidity, profitability, solvency ratios) as well as on the supervisory actions (e.g., } \\
\text { model validation, ICAAP, EBA stress tests, findings of on-site inspections): college meetings, } \\
\text { bilateral meetings, secured college webtool, official letters, mail, conference calls and } \\
\text { bilateral phone calls. }\end{array}$ \\
\hline
\end{tabular}




\begin{tabular}{|c|c|}
\hline & $\begin{array}{l}\text { The secured college webtool is used to structure and standardize the information exchange } \\
\text { within the college. This tool enables a straight through process of information and } \\
\text { communication flows between college members, instant planning and organization of } \\
\text { supervisory activities and serves as a central hub for the gathering and disseminating of } \\
\text { prudential knowledge and expertise. The tool contains an updated contact list of college } \\
\text { members. } \\
\text { The NBB noted that as college practices were maturing (and partly as a result of the greater } \\
\text { requirements imposed by the directives and the guidelines developed by CEBS and the } \\
\text { EBA) host authorities were gaining more confidence within colleges. It was becoming more } \\
\text { common for host members to organize events to focus on particular supervisory issues and } \\
\text { invite the wider college. In the view of the NBB this development is not only welcome but a } \\
\text { testament to the growing trust and effectiveness of communication within the colleges. } \\
\text { Although supervisory authorities from outside the EU are invited to EU based colleges, they } \\
\text { are obviously not bound by EU directive requirements relating to exchange of information, } \\
\text { cooperation and joint risk and capital assessments. Here too, though, the NBB had } \\
\text { observed strongly increasing contributions from non EU members. } \\
\text { Bilateral contacts also continue to be an important component of supervisory relationships } \\
\text { and frequently serve to exchange information on specific issues. }\end{array}$ \\
\hline EC4 & 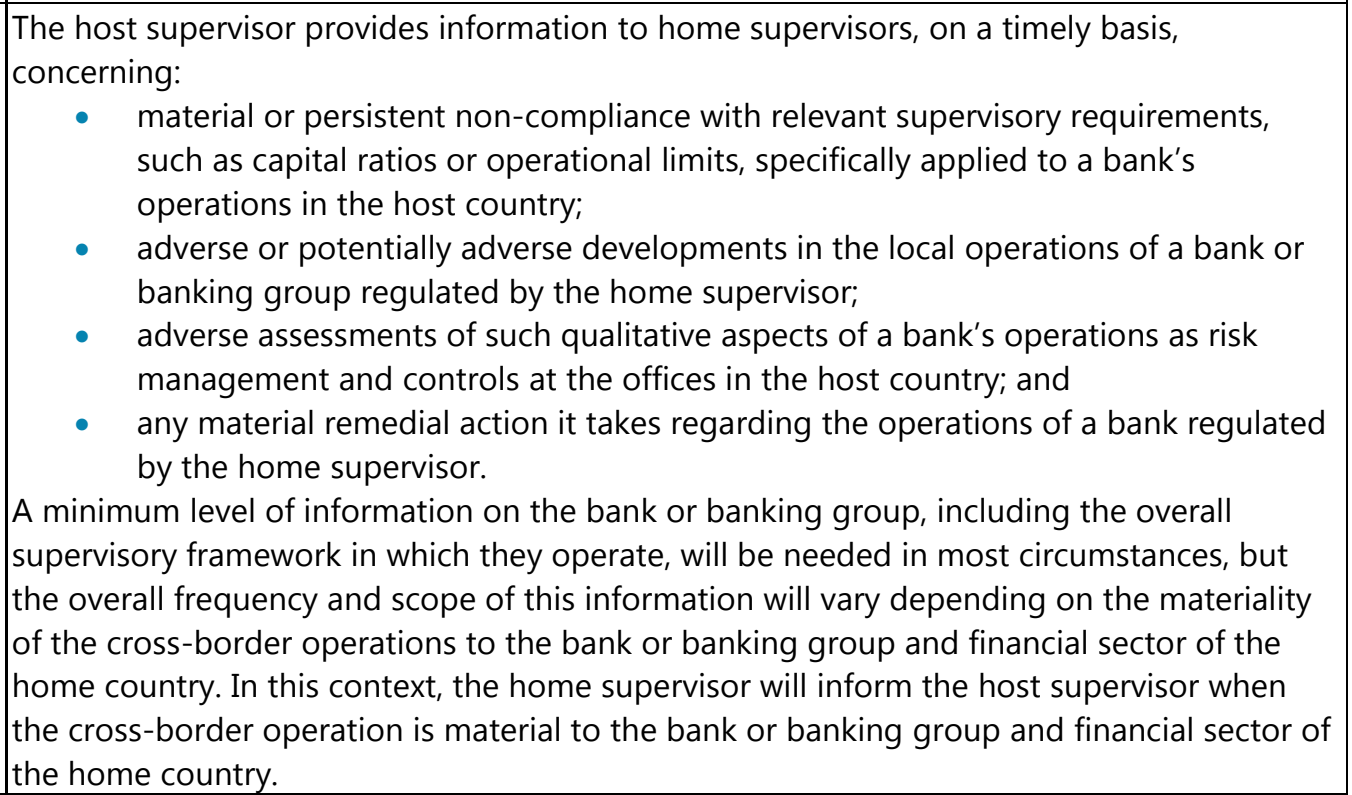 \\
\hline & $\begin{array}{l}\text { The NBB (as host supervisor) informs the home supervisor and the college of the activities, } \\
\text { the developments, the main risks and the financial position of the local group entity under } \\
\text { its supervision as well as on the supervisory activities and measures. Any adverse } \\
\text { development, or material concern or non-compliance by the entity would be reported to } \\
\text { the home supervisor on a timely or urgent basis as appropriate. } \\
\text { The frequency of information exchange can be periodically (at college meetings) or ad hoc } \\
\text { (adverse developments with potentially significant spill-over effects for the group). The } \\
\text { bilateral and, for EU colleges, multilateral MoUs aim to ensure that there is a full and } \\
\text { effective flow of information between the home and host with the home authority acting as } \\
\text { the "hub," which will also ensure dissemination of information effectively through the } \\
\text { supervisory authorities and the assessors saw documentation confirming that the NBB is as }\end{array}$ \\
\hline
\end{tabular}




\begin{tabular}{|c|c|}
\hline & $\begin{array}{l}\text { active a host member of a college as it is when it is the home authority. As noted above, } \\
\text { there are joint risk assessments for banking groups within the EU framework and the NBB } \\
\text { participates as a host supervisor as well as home supervisor. } \\
\text { In practicing risk based supervision, the NBB allocates supervisory resource proportionately, } \\
\text { but in any case, the NBB is the host authority for two institutions, which are of domestic } \\
\text { systemic relevance, so participation in college practices is a priority as is the maintenance } \\
\text { of bilateral dialogue with the relevant home country authorities to ensure the effective } \\
\text { consolidated supervision of the entire group. As a host authority, the NBB mainly focuses } \\
\text { on the following topics: } \\
\text { active contribution to the work of the (core) college; and } \\
\text { specific interest in the risks taken by the entity in the home country (including } \\
\text { intragroup exposures and asset and liabilities transfers). }\end{array}$ \\
\hline EC5 & $\begin{array}{l}\text { A host supervisor's national laws or regulations require that the cross-border operations of } \\
\text { foreign banks are subject to prudential, inspection and regulatory reporting requirements } \\
\text { similar to those for domestic banks. }\end{array}$ \\
\hline & $\begin{array}{l}\text { Belgian laws or regulations make no distinction in terms of prudential, inspection and } \\
\text { regulatory reporting requirements between domestic banks and banks with foreign } \\
\text { ownership. Moreover, Belgium is subject to EU law, which stipulates that non-EU entities } \\
\text { may not be treated more leniently in regulatory standards than domestic entities. } \\
\text { With respect to branches specifically, EU law determines that the responsibility for the } \\
\text { operation of cross border branches (within the EU/EEA) rests with the home authority } \\
\text { except in relation to the treatment of AML/CTF and liquidity supervision (the latter not yet } \\
\text { being subject to harmonized regulatory treatment in the EU). }\end{array}$ \\
\hline EC6 & $\begin{array}{l}\text { Before issuing a license, the host supervisor establishes that no objection (or a statement of } \\
\text { no objection) from the home supervisor has been received. For purposes of the licensing } \\
\text { process, as well as ongoing supervision of cross-border banking operations in its country, } \\
\text { the host supervisor assesses whether the home supervisor practices global consolidated } \\
\text { supervision. }\end{array}$ \\
\hline $\begin{array}{l}\text { Description and } \\
\text { findings re EC6 }\end{array}$ & $\begin{array}{l}\text { For subsidiaries and non-EEA branches, the NBB has to consult the home supervisor before } \\
\text { issuing a licence (Articles } 9 \text { and } 79 \text { of the Banking Law and in conformity with Article } 15 \text { of } \\
\text { Directive } 2006 / 48 / E C \text { ). For EEA-branches, the licence is based on the prior notification of } \\
\text { the establishment of a branch, which the home supervisor must send to the host } \\
\text { supervisor (Article } 65 \text { of the Banking Law). } \\
\text { For the supervision of "regulated enterprises" (including credit institutions) the Royal } \\
\text { Decree of } 12 \text { August } 1994 \text { on consolidated supervision states, which regulator is } \\
\text { responsible for consolidated supervision. For non-EEA banking groups in Belgium, the } \\
\text { Belgian regulation requires the NBB to ascertain that there is consolidated supervision } \\
\text { exercised by the home supervisor that is equivalent to that exercised by supervisors in EEA. }\end{array}$ \\
\hline EC7 & $\begin{array}{l}\text { Home country supervisors are given on-site access to local offices and subsidiaries of a } \\
\text { banking group in order to facilitate their assessment of the group's safety and soundness } \\
\text { and compliance with KYC requirements. Home supervisors should inform host supervisors } \\
\text { of intended visits to local offices and subsidiaries of banking groups. }\end{array}$ \\
\hline $\begin{array}{l}\text { Description and } \\
\text { findings re EC7 }\end{array}$ & $\begin{array}{l}\text { The NBB (in its capacity of home supervisor), has never experienced an instance of refusal } \\
\text { of on-site access to local offices and subsidiaries. }\end{array}$ \\
\hline
\end{tabular}




\begin{tabular}{|c|c|}
\hline & $\begin{array}{l}\text { The NBB frequently arranges on-site visits to material subsidiaries and branches in order to } \\
\text { deepen its understanding of their activities and to discuss with the local supervisor the } \\
\text { main risks to which it is exposed, including compliance risks. An on-site visit typically } \\
\text { includes a meeting at the premises of the host supervisor and a joint visit to the premises } \\
\text { of the local entity with "deep dive" working sessions with local management and staff. } \\
\text { Where the NBB is the home country supervisor it seeks to ensure at least annual visits to } \\
\text { material subsidiaries and branches, including joint-on-site examinations both inside and } \\
\text { outside the EU. } \\
\text { It is standard procedure for the NBB to notify its intention to conduct an on-site visit at a } \\
\text { host entity and to forward the agenda prior to the visit to the host supervisor. Most of the } \\
\text { time, the host supervisor accompanies the NBB in the on-site visit, but this is not } \\
\text { mandatory nor always the case. }\end{array}$ \\
\hline EC8 & $\begin{array}{l}\text { The host supervisor supervises shell banks, where they still exist, and booking offices in a } \\
\text { manner consistent with internationally agreed standards. }\end{array}$ \\
\hline $\begin{array}{l}\text { Description and } \\
\text { findings re EC8 }\end{array}$ & Not applicable. \\
\hline EC9 & $\begin{array}{l}\text { A supervisor that takes consequential action on the basis of information received from } \\
\text { another supervisor consults with that supervisor, to the extent possible, before taking such } \\
\text { action. }\end{array}$ \\
\hline $\begin{array}{l}\text { Description and } \\
\text { findings re EC9 }\end{array}$ & $\begin{array}{l}\text { The supervisory practices in respect of exchange of information are such that as a general } \\
\text { rule, and as codified in MoUs, the exchange specifies the use that can or is expected to be } \\
\text { made of the information and a prior consultation takes place on the intentions of the } \\
\text { receiving supervisor to take consequential action on the basis of this information. } \\
\text { Within the EU/EEA it is mandatory for the NBB to consult with its peer college authorities } \\
\text { before making a final determination on a number of issues (such as capital or models } \\
\text { approval). } \\
\text { There have been a number of documented instances of the NBB having taken } \\
\text { consequential action arising from information received from another supervisory authority. }\end{array}$ \\
\hline \multicolumn{2}{|l|}{$\begin{array}{l}\text { Additional } \\
\text { criteria }\end{array}$} \\
\hline AC1 & $\begin{array}{l}\text { Where necessary, the home supervisor develops an agreed communication strategy with } \\
\text { the relevant host supervisors. The scope and nature of the strategy should reflect the size } \\
\text { and complexity of the cross-border operations of the bank or banking group. }\end{array}$ \\
\hline $\begin{array}{l}\text { Description and } \\
\text { findings re } A C 1\end{array}$ & $\begin{array}{l}\text { A communication strategy is agreed upon in the college on beforehand or, where } \\
\text { necessary, on an ad hoc basis. } \\
\text { As a general rule, the home supervisor communicates the college's decisions and requests } \\
\text { on consolidated basis to the parent bank. Such is the case for the notification of the joint } \\
\text { risk assessment, joint capital decision and the validation of IRB-models. The communication } \\
\text { by the home supervisor to the group does not prevent the host supervisors from } \\
\text { discussing the local implications of college decisions with the local entity under their } \\
\text { supervision. }\end{array}$ \\
\hline
\end{tabular}




\begin{tabular}{|l|l|}
\hline $\begin{array}{l}\text { Assessment of } \\
\text { Principle 25 }\end{array}$ & Compliant \\
\hline Comments & $\begin{array}{l}\text { Home and host relationships are critical to the successful supervisory oversight of the } \\
\text { financial system in Belgium. Of the systemic institutions, all except one is significantly active } \\
\text { on a cross border basis, and the NBB is the home authority for only two of these systemic } \\
\text { institutions. While EU legislation provides an articulated framework for the operation of } \\
\text { colleges of supervisors in the EU, including requiring joint assessment and decision making } \\
\text { processes (with arbitration options if necessary), it is clear that the NBB places great value } \\
\text { on this process and is strongly motivated to contribute to and participate in the home-host } \\
\text { relationships as fully and as effectively as possible. The depth and quality of information } \\
\text { sharing, the joint projects undertaken, the documentation of exchanges of views between } \\
\text { authorities and actions arising from such debates attest to a maturing dialogue between } \\
\text { supervisors, which should serve the NBB well and for which the NBB's own attitude should } \\
\text { be given significant credit. }\end{array}$ \\
\hline
\end{tabular}

